
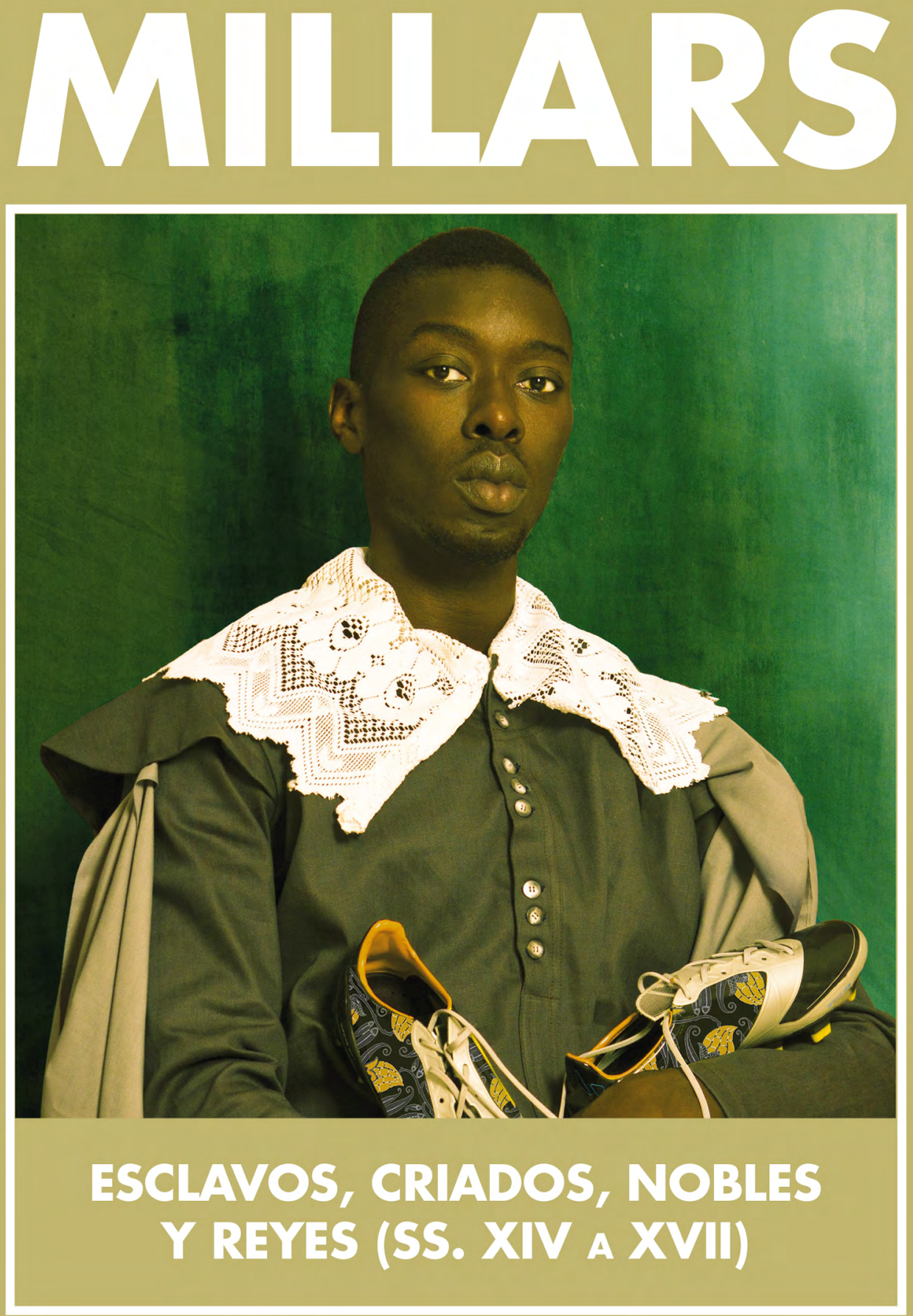

\title{
UJI UNAVERSITAT
}






\section{UJI UANIERSTIAT}

XLVII 2019/2

ESPAI I HISTÒRIA
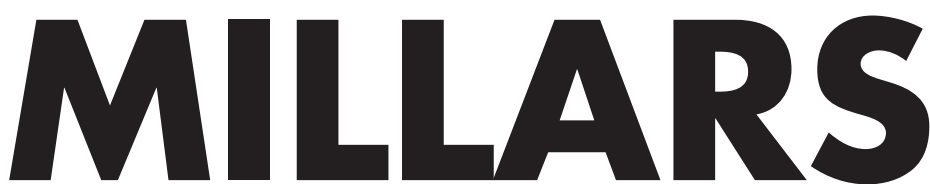

Departament d'Història, Geografia i Art 
REVISTA MILLARS. ESPAI I HISTÒRIA. -T. 1 (1974). -Castelló de la Plana:

Publicacions de la Universitat Jaume I, [1974]-

v.; $25 \mathrm{~cm}$

És continuació de: Millars

Descripció basada en: n.17 (1994)

ISSN 1132-9823

I.Universitat Jaume I (Castelló). Publicacions de la Universitat Jaume I

19 TOMO XLVII $(2019 / 2)$

Director: Vicent Sanz Rozalén (Universitat Jaume I)

Secretaria: Cristina Igual Castelló (Universitat Jaume I)

\section{Consell de Redacció:}

Josep Benedito (Universitat Jaume I); Maria Bonet (Universitat Rovira i Virgili); Françoise Crémoux (Université Paris 8); Joan Manuel Marín (Universitat Jaume I); Carles Rabassa (Universitat Jaume I); Claudia Rosas (Pontificia Universidad Católica del Perú); Patricia Solis (Arizona State University)

\section{Consell Assessor:}

Pedro Barceló (Universität Postdam); Walther Bernecker (Universität Erlangen-Nüremberg); Aura Margarita Calle (Universidad Tecnológica de Pereira); Manuel Chust (Universitat Jaume I); Carmen Corona (Universitat Jaume I); Gloria Espigado (Universidad de Cádiz); Juan José Ferrer (Universitat Jaume I); Antoni Furió (Universitat de València); Paola Galetti (Università di Bologna); Antonio Gil Olcina (Universitat d'Alacant); Angeles González (Universidad de Sevilla); Robert Kent (California State University); Ana María Leyra (Universidad Complutense de Madrid); Clelia Martínez Maza (Universidad de Málaga); Víctor Mínguez (Universitat Jaume I); Enrique Montón (Universitat Jaume I); Inmaculada Rodríguez (Universitat Jaume I); Luis Sánchez Ayala (Universidad de Los Andes); Javier Soriano (Universitat Jaume I); Cècile Vincent-Cassy (Université Paris 13)

Millars. Espai i Història apareix indexada en els següents directoris i bases de dades:

- CARHUS Plus+ - CIRC (Clasificación Integrada de Revistas Científicas) - Díalnet - DICE (Difusión y Calidad Editorial de las Revistas Españolas de Ciencias Sociales y Jurídicas) - IN-RECS (Índice de impacto de Revistas Epañolas de Ciencias Sociales) - ISOC Índice Español de Ciencias Sociales y Humanidades (CSIC) - Latindex - MIAR (Matriu d'Informació per a I'Avaluació de Revistes) - RACO (Revistes Catalanes amb Accés obert) REGESTA IMPERII: Akademie der Wissenschaften und der Literatur - RESH (Revistas Españolas de Ciencias Sociales y Humanas) - Ulrich's

DOI: http://dx.doi.org/10.6035/Millars

http://dx.doi.org/10.6035/Millars.2019.47

Millars. Espai i Història no s'identifica necessàriament amb els continguts dels artícles publicats. Prohibida la reproducció total o parcial dels artícles sense l'autorització prèvia.

Dipòsit legal: CS-84-96

Disseny: Espai Paco Bascuñán-www.espaciopacobascunan.com

Impressió: Ulzama Digital www.ulzama.com

Foto de portada: (O)mar Victor Diop. Juan de Pareja, 2014. Diaspora Series. Courtesy Galerie MAGNANIN-A, París.

Aquest text està subjecte a una llicència Reconeixement-Compartirlgual de Creative Commons, que permet copiar, distribuir i comunicar públicament l'obra sempre que s'especifique l'autoria i el nom de la publicació fins i tot amb objectius comercials i també permet crear obres derivades, sempre que siguen distribuïdes amb aquest mateixa llicència. 


\section{Sumari}

\section{Dossier}

Aurelia Martín Casares (CoOrd.)

Esclavos, Criados, Nobles y Reyes (ss. XIV a XVII)

\section{Aurelia Martín Casares}

Presentación.

\section{Raúl González Arévalo}

La esclavitud en la España Medieval. (siglos XIV-XV).

Generalidades y rasgos diferenciales

Slavery in late medieval Spain (14th-15th centuries).

Generalities and differential features

\section{Maxim Rigaux}

¿Servir con la pluma? El efecto espejo en el Austrias

Carmen de Juan Latino

To serve with the pen: the mirror effect in Juan Latino's Austrias Carmen.

\section{Sandra Martínez Rossı}

Esclavos y criados: metáforas visuales y mundos imaginarios

Slaves and servants: visual metaphors and imaginary worlds.

\section{María Teresa Morabito y María luisa Tobar}

La legendaria vida del renegado calabrés Uchalí que de esclavo llega a ser rey en la historia y en la literatura

The legendary life of the Calabrian renegade Uchalí who being slave he becomes king in history and in literature. 


\section{Valentina Oldrati}

El triple ascenso de Pietro Velasco. Cautiverio, promoción del talento y "asimilación antagonista" entre Cristiandad e Islam (1583-1608)

The triple rise of Pietro Velasco. Captivity, talent promotion and "antagonistic assimilation" between Christendom and Islam (1583-1608)

\section{Tamara láñez Ramírez}

La población esclava según las Cédulas Reales concedidas a la familia Ponce de León en el Puerto Rico del siglo XVI Evolution of the slave population through the Royal Cedules granted to the Ponce de León Family in the Puerto Rico of the 16th century.

\section{Estudis}

\section{Ma Dolores Villaverde Solar}

Mujer, guerra y arte: Simbolismo en los collages de Amparo Segarra

Woman, War, and Art: Simbolism in Amparo Segarra's collages 


\section{Dossier}

\section{Esclavos, Criados, Nobles y Reyes \\ (ss. XIV a XVII)}

\section{Aurelia Martín Casares \\ Coordinadora}

\section{Aurelia Martín Casares}

Presentación

\section{Raúl González Arévalo}

La esclavitud en la España Medieval. (siglos XIV-XV). Generalidades y rasgos diferenciales

\section{Maxim Rigaux}

¿Servir con la pluma? El efecto espejo en el Austrias Carmen de Juan Latino

\section{Sandra Martínez Rossi}

Esclavos y criados: metáforas visuales y mundos imaginarios

\section{María Teresa Morabito y María Luisa Tobar}

La legendaria vida del renegado calabrés Uchalí que de esclavo llega a ser rey en la historia y en la literatura

\section{Valentina Oldrati}

El triple ascenso de Pietro Velasco. Cautiverio, promoción del talento y "asimilación antagonista" entre Cristiandad e Islam (1583-1608)

\section{TAMARA láÑEz RAmírez}

La población esclava según las Cédulas Reales concedidas a la familia Ponce de León en el Puerto Rico del siglo XVI 



\title{
PRESENTACIÓN
}

\author{
Aurelia Martín Casares \\ Universidad de Málaga
}

El nexo común de los artículos publicados en este número monográfico titulado "Esclavos, criados, nobles y reyes (ss. XIV a XVII)" es la construcción de relaciones simbólicas e históricas entre esclavitud, cautiverio, nobleza y realeza.

En concreto, tres artículos, de los aquí contenidos, se refieren al ámbito peninsular español, dos al mundo mediterráneo y uno al Caribe. El primer bloque comprende los textos de Raúl González Arévalo, Maxim Rigaux y Sandra Martínez Rossi. El primero aborda el estudio de la esclavitud en las Coronas de Aragón y Castilla, planteando una visión general del fenómeno esclavista que pone de relieve la marginalidad como elemento inherente a la esclavitud, destacando aspectos como la procedencia de la esclavos en el mundo ibérico medieval, la imagen del esclavo-animal, de la esclava como objeto sexual y el camino hacia la libertad. González Arévalo, señala por ejemplo, que la integración pasaba por establecer relaciones personales, fundando una familia o formando parte de una cofradía. Por su parte, Rigau estudia la obra de Juan Latino, esclavo de los duques de Sessa, criado con el nieto del Gran Capitán, y primer humanista afroeuropeo del siglo XVI. Rigau aborda el "efecto espejo" (un efecto similar a Las Meninas de Velázquez) del Austrias Carmen, un poema épico de dos cantos en latín que celebra la victoria cristiana en la batalla de Lepanto, y que fue publicado por el maestro Juan Latino en Granada. El artículo de Martínez Rossi es una reflexión sobre la imagen de los esclavos en determinadas obras pictóricas del Barroco desde la perspectiva antropológica y del análisis 
visual. En este marco, la autora nos presenta la versión contemporánea que el artista senagalés Omar Diop ha realizado del retrato de Juan de Pareja, el esclavo de Velázquez, cuestionando la propia construcción de la historia y de sí mismo, como artista y como persona.

El segundo bloque lo constituyen dos artículos centrados en la esclavitud y el cautiverio en el espacio mediterráneo. En concreto, el artículo de María Teresa Morabito y María Luisa Tobar aborda la fascinante vida de un renegado italiano, Dionisio Galeno, más conocido como Uchalí, que fue esclavizado y llegó a convertirse en adalid de los turcos en la batalla de Lepanto, además de ser Rey de Argel y Capitán General del Mar. Su asombrosa vida fue retratada por Cervantes y por otros autores del Siglo de Oro. Por su parte, el texto de Valentina Oldrati trata la vida de Pietro Velasco, quien llegó a formar parte de la armada del Kapudan Pachá Scipione Cicala y cuya vida constituye un ejemplo de la estrecha relación entre la conversión religiosa y el ascenso social de los cautivos y renegados que desplegaron el talento necesario para reorientar sus carreras en el complejo ámbito mediterráneo del siglo XVI, más concretamente en el contexto de la rivalidad Habsburgo-otomana.

Y, por último, el artículo de Tamara láñez, centrado en la esclavitud caribeña, analiza las relaciones entre esclavitud y nobleza, a través del estudio de una influyente familia puertoriqueña en las primeras décadas de la colonización de la isla de San Juan. lañez aborda el papel de Juan Ponce de León en la esclavitud puertoriqueña, y a través de la familia Ponce de León, reflexiona sobre la evolución de la población esclava en la isla, desde la esclavitud por guerra al proceso de liberación posterior.

Este número monográfico forma parte de los resultados del Proyecto de I+D (HAR2016-80091-P) del Plan Nacional de Investigación del Ministerio de Economía, Industria y Competitividad titulado "Esclavos y criados de Nobles y Reyes (s. XIV a XVII" y de la Red de Excelencia que lleva por nombre "Esclavitud, servicio doméstico, mestizaje y abolicionismo en los mundos hispánicos" (HAR2017-90783-REDT). 


\section{LA ESCLAVITUD EN LA ESPAÑA BAJOMEDIEVAL (SIGLOS XIV-XV). GENERALIDADES Y RASGOS DIFERENCIALES}

\section{SLAVERY IN LATE MEDIEVAL SPAIN (14TH-15TH CENTURIES). GENERALITIES AND DIFFERENTIAL FEATURES}

Raúl González Arévalo

Universidad de Granada

\section{RESUMEN}

El presente artículo aborda desde una perspectiva general e integradora el conocimiento de la esclavitud en los territorios de lo que hoy es España en época bajomedieval, centrado en las Coronas de Aragón y Castilla en los siglos XIV y XV. Se estudia la imagen mediática de la esclavitud; la procedencia de las personas esclavizadas y su distribución ibérica; la imagen del esclavo, su trabajo, su vida y su posición en la sociedad; los propietarios, las dificultades para alcanzar la libertad y el estigma de los libertos.

Palabras clave: Resclavitud, España medieval, comercio, trabajo, vida, sociedad.

\section{ABSTRACT}

The present paper tackles from a general and integrating perspective the knowledge of slavery in the late medieval territories that today shape Spain, focusing in the Crowns of Aragon and Castile in the 14th and 15th centuries. It deals with media image of slavery; the origin of enslaved people and their Iberian distribution, the slave's image, labour, life and social position; owners, the difficulties to reach liberty and freed slaves' stigma.

Keywords: slavery, Medieval Spain, trade, labour, life, and society. 


\section{RESUM \\ L'ESCLAVITUD A L'ESPANYA MEDIEVAL (SEGLES XIV-XV). GENERA- LITATS I TRETS DIFERENCIALS}

El present article tracta des d'una perspectiva general i integradora el coneixement de l'esclavitud als territoris del que avui dia és Espanya en la baixa edat mitjana, centrat a les Corones d'Aragó i Castella en els segles XIV i XV. S'estudia la imatge mediàtica de l'esclavitud; la procedència de les persones esclavitzades i la seua distribució ibèrica; la imatge de l'esclau, el seu treball, la seua vida i posició en la societat; els propietaris, les dificultats per aconseguir la llibertat i l'estigma dels lliberts.

Paraules clau: Resclavitud, Espanya medieval, comerç, treball, vida, societat. 


\section{Del cine a la esclavitud medieval}

Cuando hablamos de esclavitud hoy día las imágenes e ideas que todos tenemos en la cabeza de modo inconsciente nos llevan inmediatamente a la Antigüedad y las colonias americanas. El cine es responsable en buena medida de esta circunstancia, pues la imagen del esclavo es fácilmente reconocible en la Roma imperial, con esclavos y gladiadores en películas como Espartaco o Gladiator. De la misma manera, se ha difundido la imagen de la trata negrera que entre los siglos XVI y XIX arrancó 11 millones de personas de sus casas en el África subsahariana para llevarlas contra su voluntad a América, según han estimado las investigaciones promovidas desde la UNESCO a través de su programa The Slave Route, cuyo objetivo declarado era dar a conocer la tragedia y devolver la dignidad a los seres humanos que sufrieron esta tragedia, saliendo del rincón del olvido de la Historia. ' Las huellas de esta migración forzosa son visibles en la población mulata de Sudamérica, especialmente en Brasil y el Caribe, en islas como Cuba, donde la esclavitud fue particularmente fuerte. En Estados Unidos la conciencia de la esclavitud es mayor aún y la población afroamericana la recuerda para reivindicar igualdad en materia de derechos civiles y sociales. Hollywood lo ha plasmado puntualmente, pasando de la imagen amable de la esclavitud doméstica y agrícola de Lo que el viento se llevó, con el primer Óscar como actriz secundaria para una intérprete negra

1 Un buen resumen en THOMAS, Hugh (2001), La trata de esclavos. Historia del tráfico de seres humanos de 1440 a 1870, Planeta, Madrid. 
(Hattie McDaniel) en 1939, a la imagen más dura y realista de 12 años en esclavitud, Óscar a la mejor película en $2014 .^{2}$

Lo cierto es que la esclavitud es uno de los fenómenos más antiguos de la Humanidad. No hay prácticamente civilización desde la Antigüedad hasta la época contemporánea que no la haya conocido. ${ }^{3}$ Durante la Alta Edad Media convivieron un gran número de formas de dependencia, incluida la esclavitud, si bien es cierto que como tal prácticamente había desaparecido en Europa occidental, salvo en zonas muy puntuales, en la península ibérica, Italia y el sur de Francia. ${ }^{4}$ Precisamente por una parte la lucha con el Islam provocó un flujo importante de esclavos desde los reinos cristianos hacia al-Andalus, y por otra llegaban las rutas caravaneras con esclavos subsaharianos. En sentido inverso, conforme avanzó la conquista cristiana sobre el Islam andalusí aumentó el volumen de musulmanes privados de libertad en el norte peninsular. ${ }^{5}$ Con todo, cabe precisar que muchos de ellos eran cautivos, no esclavos. Aunque hay una tendencia actual a asimilar los dos fenómenos por las coincidencias en la privación de libertad de las personas y su explotación laboral, lo cierto es que en realidad se trataba de dos situaciones jurídicamente bien diferenciadas, en el Islam como en la Cristiandad, en la que lejos de ser dos caras de una misma realidad, lo cierto es que el cautiverio es un estadio jurídicamente anterior, que no conducía necesariamente a la esclavitud, y que tenía sus propios mecanismos. ${ }^{6}$

2 Para un estudio sobre el cine como el principal medio difusor de la historia de la esclavitud véase Z. DAVIS, Natalie, (2002), Slaves on Screen. Film and Historical Vision, Harvard University Press, Cambridge (MA); y MARTIN, Michael T., y WALL, David C. (2013), "The Politics of Cine-Memory: Signifying Slavery in the History Film", en ROSENSTONE, Robert A. y PARVULESU, Constantin (eds.), A Companion to the Historical Film, Wiley-Blackwell, Oxford, pp. 445-467.

3 Para un recorrido de la historia de la esclavitud desde la Prehistoria hasta nuestros días puede verse MELTZER, Milton (1993), Slavery. A World History, Da Capo Press, Nueva York.

4 No se ha repetido el esfuerzo integrador de la obra clásica de VERLINDEN, Charles (1955), L'esclavage dans l'Europe médiévale. Tome I: Péninsule Ibérique, France, De Tempel, Brujas; y (1977), L'esclavege dans l'Europe médiévale. Tome II: Italie - Colonies italiennes du Levant Levant latin - Empire byzantin, Rijksuniversiteit, Gante. Una puesta al día sobre la servidumbre y la esclavitud en Europa en CAVACIOCCHI, Simonetta (ed.) (2014), Schiavitù e servaggio nell'economia europea, secc. XI-XVIII, Firenze University Press, Florencia.

5 A falta de un volumen específico sobre la esclavitud en al-Andalus me remito a los estudios contenidos en FIERRO, Maribel y GARCÍA-FITZ, Francisco (eds.) (2008), El cuerpo derrotado: cómo trataban musulmanes y cristianos a los enemigos vencidos (Península lbérica, ss. VIII-XIII), CSIC, Madrid. 
La esclavitud bajomedieval es fruto del renacimiento de la trata en los inicios del siglo XIII, no de la evolución de las situaciones de dependencia conocidas en la Europa de la Alta y la Plena Edad Media. Impulsada por las repúblicas mercantiles italianas, Génova y Venecia, que contaban con importantes colonias en el Levante mediterráneo y Próximo Oriente, empezaron a exportar esclavos eslavos al sultanato mameluco de Egipto y hacia el Mediterráneo occidental. A diferencia de la esclavitud antigua y moderna, eminentemente rurales, la esclavitud europea fue un fenómeno esencialmente urbano, circunscrito al ámbito del Mediterráneo. ${ }^{7}$ En consecuencia, por lo que respecta a la península ibérica, se desarrolló antes en la Corona de Aragón que en la de Castilla donde, por el contrario, seguía teniendo más peso el botín obtenido con la "guerra del moro", las luchas seculares con los musulmanes de al-Andalus, en la que el cautivo enemigo era el botín más preciado. De hecho, Castilla no se incorporó con fuerza a los circuitos esclavistas mediterráneos hasta después de la conquista del Reino de Granada a finales del siglo XV, ya durante el reinado de los Reyes Católicos. De la misma manera, tampoco Portugal tuvo una participación relevante en esta esclavitud mediterránea.

Los historiadores de la esclavitud europea hacen enorme hincapié no sólo en la aceptación que tenía entre la población el hecho esclavo, con un discurso jurídico, ideológico y teológico que lo justificaba, articulado en torno a los escritos de autores de la Antigüedad (encabezados por Aristóteles) y la Edad Media, incluyendo San Agustín y Santo Tomás de Aquino. Efectivamente, los argumentos a favor de la esclavitud son muchos y variados, y constituyeron un corpus coherente, aunque no homogéneo. ${ }^{8}$

6 Para las diferencias entre cautiverio y esclavitud en la Baja Edad Media ibérica me remito a GONZÁlEZ ARÉVALO, Raúl (2006), El cautiverio en Málaga a fines de la Edad Media, CEDMA, Málaga, pp. 23-36. Para los cautivos cristianos y musulmanes en la Península lbérica véase el magnífico volumen de CALDERÓN ORTEGA, José Manuel y DÍAZ GONZÁLEZ, Francisco Javier (col.) (2012), Vae Victis. Cautivos y prisioneros en la Edad Media Hispánica, Universidad de Alcalá de Henares, Madrid.

7 HEERS, Jacques (1989), Esclavos y sirvientes en las sociedades mediterráneas durante la Edad Media, Institución Alfonso el Magnánimo, Valencia. Una puesta al día reciente, referida al cautiverio y la esclavitud, en los estudios contenidos en GUILLEN, Fabienne y TRABELSI, Salah (eds.) (2012), Les esclavages en Méditerranée. Espaces et dynamiques économiques, Casa de Velázquez, Madrid.

8 GARCÍA AÑOVEROS, Jesús (2000), El pensamiento y los argumentos sobre la esclavitud en Europa en el siglo XVI y su aplicación a los indios americanos y a los negros africanos, CSIC, Madrid. 


\section{Geografía Y procedencia de la esclavitud ibérica}

La situación de la península ibérica entre el Mediterráneo y el Atlántico hace que se puedan distinguir dos áreas en las que los mecanismos de aprovisionamiento de personas esclavizadas estaban diferenciados. Efectivamente, la Corona de Aragón se integró rápidamente en los circuitos esclavistas mediterráneos que la abastecieron de individuos de procedencia oriental y de musulmanes, mientras que en Castilla tuvo más importancia el desarrollo de la trata negrera africana en cuyo impulso Portugal tuvo un papel decisivo desde mediados del siglo XV. Pero ambos territorios compartían una característica: la presencia más abundante en las ciudades cercanas a la costa y más débil en el interior. De hecho, en el sur peninsular se puede trazar una frontera invisible entre el sur del río Guadiana, con la Extremadura meridional y Andalucía como territorios de mayor presencia esclava, y el interior, donde apenas está constatada. Por su parte, en la Corona de Aragón destacan la costa catalana y valenciana, así como el Reino de Mallorca. Así lo han confirmado los estudios específicos sobre la materia, que han determinado que los grandes centros esclavistas peninsulares eran Lisboa y Sevilla para la trata atlántica; ${ }^{9}$ Málaga en el Reino de Granada después de la conquista castellana, a caballo entre el Mediterráneo y el Atlántico; ${ }^{10}$ y Barcelona, Valencia y Palma de Mallorca en el Mediterráneo ibérico. ${ }^{11}$

Inicialmente la presencia de la esclavitud mediterránea en la Corona de Aragón se centró en la capital catalana, Barcelona, el centro indiscutible

9 FRANCO SILVA, Alfonso (1979), La esclavitud en Sevilla y su tierra a fines de la Edad Media, Diputación Provincial de Sevilla, Sevilla.

10 GONZÁlEZ ARÉVALO, Raúl (2006), La esclavitud en Málaga a fines de la Edad Media, Universidad de Jaén, Jaén.

11 CORTÉS, Vicenta (1964), La esclavitud en Valencia durante el reinado de los Reyes Católicos, Ayuntamiento de Valencia, Valencia; VAQUER BENNASSAR, Onofre (1997), L'esclavitud a Mallorca, 1448-1500, Consell Insular de Mallorca, Palma de Mallorca; SALICRÚ, Roser (1998), Esclaus i propietaris d'esclaus a la Catalunya del segle XV. L'assegurança contra fugues, CSIC, Barcelona; HERNANDO, Josep (2003), Els esclaus islàmics a Barcelona: blancs, negres, llors i turcs. De l'esclavitud a la llibertat (s. XIV), CSIC, Barcelona. MARZAL, Francisco Javier (2006), La esclavitud en Valencia durante la Baja Edad Media (1375-1425), Universitat de València, Valencia; BLUMENTHAL, Debra (2009), Enemies and Familiars: Slavery and Mastery in Fifteenth-Century Valencia, Cornell University Press, Ithaca; ARMENTEROS, Iván (2015), L'esclavitud a la Barcelona del Renaixement (1479-1516). Un port mediterrani sota la influència del primer tràfic negrer, Fundació Noguera, Barcelona; FERRER ABÁRZUZA, Antoni (2015), Captius i senyors de captius a Eivissa. Una contribució al debat sobre l'esclavitud 
en Cataluña. En el siglo XIV los catalanes se abastecían en el Mar Egeo de esclavos orientales (tártaros, rusos circasianos, abjasios, mingrelianos). En el Mediterráneo central había relaciones fuertes de aprovisionamiento con Génova y Sicilia, donde adquieren esclavos de procedencia muy diversa, desde sarracenos norteafricanos hasta eslavos de los Balcanes (albaneses, bosnios, búlgaros, esclavones y griegos). Con todo, el avance del Imperio otomano en el Mediterráneo oriental y el cambio de las dinámicas comerciales hicieron que a finales del siglo XV la esclavitud oriental y balcánica fuera residual, frente al auge de magrebíes $y$, más adelante, de subsaharianos, cuando el impacto de la trata atlántica cambió para siempre el mercado barcelonés. ${ }^{12}$

Mallorca también fue un importantísimo centro esclavista desde su conquista en el siglo XIII, y los estudios demuestran que, al menos al principio, la actividad agrícola estaba en manos de esclavos musulmanes, que progresivamente fueron sustituidos por campesinos libres asalariados ante el temor, entre otras cosas, de una rebelión en la isla, pues al principio había más esclavos que libres. ${ }^{13}$

Con todo, el gran centro esclavista a partir del siglo XV en la Corona de Aragón fue Valencia, que compitió con Barcelona como centro comercial y financiero más dinámico. El volumen de cifras es impresionante, sólo por detrás de Lisboa en todo Occidente. Se observa una evolución desde la diversidad del siglo XIV, con esclavos orientales y balcánicos como en Barcelona, pues conforme avanza el siglo XV la presencia de grandes mercaderes de esclavos desemboca en un flujo constante, cada vez mayor, de individuos privados de libertad procedentes del África negra, llevados por los portugueses; de canarios, esclavizados por castellanos; y de moros,

medieval (segles XIII-XVI), Universitat de València, Valencia. Además, en el siguiente volumen colectivo la mayoría de las contribuciones se refieren al ámbito de la Corona de Aragón: FERRER, María Teresa y MUTGÉ, Josefina (eds.) (2000), De l'esclavitud a la llibertat: Esclaus i lliberts a l'edat mitjana, CSIC, Barcelona.

12 Como resulta evidente de la lectura de los trabajos de Josep Hernando e Iván Armenteros citados en la nota anterior.

13 SOTO, Ricardo (2012), "La conquista de Mallorca y la creación de un mercado de esclavos" y MAS FORNERS, Antoni (2012), "La incidencia del mercado de esclavos en la estructura productiva de Mallorca (c. 1300-1450)", en GUILLEN y TRABELSI, Les esclavages en Méditerranée, pp. $63-76$ y 77-100, respectivamente. 
reducidos a esclavitud por catalanes. Esto la convirtió junto con Génova y Venecia en uno de los grandes mercados de esclavos de todo el Mediterráneo occidental. ${ }^{14}$

En la Corona de Castilla mientras hubo frontera terrestre con el Islam, con el Reino de Granada, hasta finales del siglo XV, la presencia de esclavos moros fue más importante en las zonas fronterizas, Andalucía y el Reino de Murcia. La guerra del moro y la esclavitud de musulmanes fue el tipo que definió la esclavitud en Castilla en el siglo XIV y principios del XV. ${ }^{15}$

Por otra parte, en la fachada atlántica la trata negrera de origen portugués se dejó notar con mucha fuerza a partir de 1450. No era ajeno el impacto del nuevo comercio con América, pues muchos mercaderes aprovechaban la presencia de la Casa de la Contratación en Sevilla para contratar la exportación de esclavos africanos a cambio de productos del Nuevo Mundo. El papel redistribuidor de Sevilla no era nuevo: desde el siglo XV se exportaban esclavos a los demás puertos andaluces -Cádiz, Puerto de Santa María, Sanlúcar de Barrameda, cabeceras asimismo para las expediciones contra el Magreb occidental, en las que se esclavizaban árabes y berberiscos norteafricanos- pero también del Mediterráneo occidental como Valencia, Barcelona, Génova y Pisa. ${ }^{16}$

Con la conquista de Granada en 1492 el nuevo territorio incorporado se convirtió también en un gran mercado esclavista, pero con caracteres propios: la cercanía con las costas del Norte de África y las operaciones bélicas contra el Magreb hicieron que en los albores de la Modernidad en esta parte de la Península lbérica tuviera mucho más peso la población esclava de origen musulmán que en el resto de la Península.

Entre los esclavos musulmanes -también llamados blancos por el color de la piel, en contraposición a los negros, o de manera genérica "moros"encontramos árabes, beréberes y turcos. Algunos procedían del emirato nazarí (Granada y Málaga), otros de la costa mediterránea del Magreb, la 'Berbería de Levante' (Trípoli, Túnez, Bona, Orán, Tremecén, Monastir, Sfax) y por último, los menos, de la 'Berbería de Poniente', el Magreb atlántico (Arcila, Azamor). Se trata de una esclavitud ligada a empresas

14 Véanse las publicaciones de Francisco Javier Marzal y Vicenta Cortés en la nota 11.

15 MOLINA, Ángel Luis (1978), "Contribución al estudio de la esclavitud en Murcia a fines de la Edad Media (1475-1516)", Murgetana, n53, pp. $111-134$.

16 Para una visión global sobre la esclavitud en Andalucía me remito a FRANCO SILVA, Alfonso (1992), La esclavitud en Andalucía (1450-1550), Editorial Universidad de Granada, Granada. 
bélicas, que tuvieron un enorme impacto en los mercados ibéricos, como la conquista de Málaga (1487): la práctica totalidad de la población, unos 11.000 individuos, fue reducida al cautiverio por derecho de guerra y terminó siendo vendida como esclava en las ciudades andaluzas -Sevilla, Córdoba y Jerez de la Frontera- pero también en Valencia y Barcelona. ${ }^{17}$

Las otras conquistas castellanas fuera de la Península Ibérica también se dejaron sentir en los mercados hispanos. Los primeros esclavos canarios llegaron a Sevilla a finales del siglo XIV, aunque la mayor afluencia tuvo lugar con el sometimiento definitivo del archipiélago a finales del siglo XV, tras la conquista de Tenerife y la represión de la revuelta de La Gomera, cuando guanches y gomeros fueron vendidos en abundancia en el mercado hispalense y Valencia. ${ }^{18}$ Por su parte, la toma de las principales plazas norteafricanas -Orán en 1509, Bujía y Trípoli en 1510-proporcionaron abundante población esclava árabe, pero también judía.

La esclavitud negra es diferente. Desde finales del siglo XIII y durante dos siglos a los puertos de la Corona de Aragón llegaban negros de los "Montes de Barca", en la actual Libia, donde se embarcaban esclavos procedentes de África central, pertenecientes a las etnias kanem y hausa. Sin embargo, a partir de la segunda mitad del siglo XV se impuso con fuerza el nuevo eje esclavista Lisboa-Sevilla-Valencia -el más importante de Europa occidental, uniendo los principales mercados ibéricos- de la mano de los mercaderes portugueses que desde la capital lusa distribuían esclavos procedentes de África occidental. Así, detrás de la procedencia genérica de "Guinea" -localizada entre Senegambia y el Golfo de Guinea- en ocasiones es posible determinar el origen étnico de los esclavos, fundamentalmente wolofes y mandingas. ${ }^{19}$

La presencia de una población esclava de origen etnogeográfico tan diverso dio lugar a la aparición de cruces raciales que desembocaron en la acuñación de una nueva categoría, los "loros", que en realidad no eran otra cosa que esclavos mulatos, aunque, a diferencia de la América colonial, en el mundo ibérico medieval nunca fueron numerosos.

17 LADERO QUESADA, Miguel Ángel (1967), "La esclavitud por guerra a fines del siglo XV: el caso de Málaga", Hispania, n 105, pp. 63-87.

18 FRANCO SILVA, Alfonso (1988), "El esclavo canario en el mercado de Sevilla a finales de la Edad Media (1470-1525)", en VIII Coloquio de Historia Canario-Americana, Cabildo Insular de Gran Canaria, Las Palmas de Gran Canaria, tomo 1, pp. 54-66.

19 CORTÉS, Vicenta (1972), "Procedencia de los esclavos negros de Valencia (1482-1516)", Revista Española de Antropología Americana, n 7/1, pp. 123-152. 


\section{¿Hombre-ANImal? ¿esclava SeXUal? Entre el estereotipo y la Realidad}

Sobre la población esclava se han generado y perviven una serie de imágenes que oscilan entre el estereotipo y la realidad. En primer lugar cabe abordar la imagen del hombre-mercancía, directamente relacionada con la del hombre-animal, cuya generalización han reivindicado vehementemente algunos autores. Se trata de una realidad indiscutible, que emerge con fuerza de los protocolos notariales, y más concretamente de las cartas de compraventa, en las que la descripción física de la mercancía y su estado -enfermedades, heridas, señales o características particulares- han servido para señalar un proceso de animalización de la persona hasta integrarlo en el ganado humano que constituía la población esclava. Los términos para designar el color de la piel, así como el uso de los términos "pieça" - "cabeça" de esclavo también proceden de la nomenclatura animal, aúnque quienes abogan por la realidad de la imagen tópica del esclavo-animal se han centrado sobre todo en la reivindicación del uso reiterado de hierros y herrajes. ${ }^{20}$ Sin embargo, la documentación hispana revela que su empleo no era en absoluto mayoritario.

La asimilación con el mundo animal resulta especialmente evidente cuando los esclavos figuran junto al ganado en las normativas municipales. Un buen ejemplo lo ofrecen las de Gran Canaria (1531), cuyas ordenanzas prohibían a quienes no fueran vecinos llevar carretas "ni camello, ni bestias, ni esclavos" al puerto de la ciudad. Así, el individuo privado de libertad recibía claramente el tratamiento de bestia de carga. ${ }^{21}$ En Sevilla los pregoneros tenían que pregonar "esclavo, o cavallo, o mula, o otra cosa que anduviese perdida" por las principales plazas de la ciudad. ${ }^{22}$ Más aún, en las localidades rurales el esclavo podía valer incluso menos que el ganado. Es lo que vemos en Alcalá de los Gazules, en el Estrecho de Gibraltar, donde el marqués de Tarifa ordenaba que a la hora de expropiar bienes por deudas se buscaran primero bueyes y vacas; si no hubiera, en cerdos; posteriormente en ovejas; y por último, si el deudor no tenía ganado, en sus esclavos; por detrás sólo se situaban los bienes raíces. ${ }^{23}$

20 STELLA, Alessandro (1996), "Herrado en el rostro con una S y un clavo: I'homme-animal dans I'Espagne des siècles XV-XVIII", en BRESC, Henri (dir.), Figures de l'esclave au Moyen Age et dans le monde moderne, L'Harmattan, París, pp.147-163 (trad.1998, Palabras de la CEIBA, 1, pp. 22-32).

21 MORALES PADRÓN, Francisco (1974), Ordenanzas del concejo de Gran Canaria (1531), Ediciones del Cabildo Insular de Gran Canaria, Gran Canaria, pp. 103-4.

22 ESCOLANO PÉREZ, Víctor (ed.) (1632/1975), Ordenanzas de Sevilla, fol. 85v. 
No puedo concluir este recorrido sobre los estereotipos que rodean al ser esclavo sin aludir a otra imagen muy extendida y que atañe de manera exclusiva a la mujer. Me refiero a la de la esclava entendida como objeto sexual. ${ }^{24}$ Su arraigo en la mentalidad colectiva ha sido posible gracias a diversos factores, que abarcan desde la escasa atención que se ha prestado a las relaciones homosexuales amo-esclavo, hasta la invisibilidad que preside las relaciones ama-esclavo, entre otras cuestiones por las exigencias que imponía el papel de la mujer como depositaria del honor familiar y de la colectividad. Pero, sin duda, han sido los planteamientos de corte pretendidamente biológico los que más han fomentado su difusión. Efectivamente, las sociedades ibéricas de los siglos XIII-XV toleraban la cohabitación de amo-esclava, aunque oficialmente las relaciones fuera del matrimonio estuvieran prohibidas. ${ }^{25}$ En cualquier caso, la asunción de esta realidad no puede llevar implícito el consentimiento de la mujer esclava, pues aunque no haya muchos testimonios sobre el tema, no cabe duda de que estas mujeres eran forzadas en su mayoría. Sin embargo, la consideración de objeto legal les impedía defenderse por este motivo. Más aún, las relaciones sexuales sólo eran denunciadas cuando los dueños se consideraban perjudicados si las esclavas las habían mantenido -forzadas o consentidas- sin su autorización. ${ }^{26}$

\section{EL ESCLAVO, UN SER MARGINAL}

Independientemente de la legalidad y la legislación de la época, que convertía a los esclavos en objetos jurídicos, está claro que la población esclava estaba compuesta por seres humanos que seguían patrones de

23 FERNÁNDEZ GÓMEZ, Marcos (1991), Alcalá de los Gazules en las ordenanzas del marqués de Tarifa. Un Estudio de legislación local en el Antiguo Régimen, Cádiz, Título XLI, 31, p. 264

24 STELLA, Alessandro (1997), "Des esclaves pour la liberté sexuelle de leurs maîtres (Europe occidentale, XIVe-XVIII'siècles)", CLIO, Histoire, Femmes et Sociétés, n 5, pp. 191-209.

25 STELLA, Alessandro (2000), "Mezclándose carnalmente. Relaciones sociales, relaciones sexuales y mestizaje en la Andalucía occidental", en ARES, Berta y STELLA, Alessandro (dirs.), Negros, Mulatos, Zambaigos. Derroteros africanos en los mundos ibéricos, Escuela de Estudios Hispano Americanos, Sevilla, pp. 175-188.

26 Aunque posterior al marco cronológico de este estudio, resultan interesantes las consideraciones de GARRIDO GARCÍA, Carlos Javier (2018), "Las esclavas moriscas en el reino de Granada tras la rebelión de 1568-1571: cotización en el mercado y explotación laboral y sexual", eHumanista/Conversos, n 6, pp. 325-345. 
comportamientos sociales. La procedencia externa a las sociedades que los esclavizaban con frecuencia reveló comportamientos que chocaban y se prohibían. Al mismo tiempo, la propia marginación del colectivo favoreció la aparición de sincretismos, comportamientos y actividades practicados sólo por los esclavos que, a pesar de sus orígenes culturales diferenciados, compartían el estado de privación de libertad. ${ }^{27}$

Con todo, quiero precisar que aunque se hable en sentido genérico del esclavo, hace ya mucho tiempo que está ampliamente aceptada la premisa de que la población esclava no constituía una categoría social dado que las condiciones de vida privado de libertad diferían notablemente de un individuo a otro. En este sentido, es fácil comprender que no vivía igual un esclavo doméstico de un noble que el de un artesano. Y tampoco vivirían igual los esclavos en la ciudad que en el campo.

Sin embargo, la negación de la categoría social no puede conducir a la negación del grupo. Desde el punto de vista de la antropología cultural hay que aceptar la condición del esclavo como miembro de un colectivo cuyo nexo de unión es una cultura externa a la de la sociedad en la que se inserta, y de la que asimila nuevos modos que integra con los anteriores a través de un proceso de aculturación. En este sentido, en la Península Ibérica se podrían distinguir fundamentalmente dos grupos de esclavos, los moros y los negros.

No cabe duda de que los comportamientos ajenos a la sociedad cristiana son los que más recelo despertaban entre las autoridades castellanas. De ahí las disposiciones que prohibían que los esclavos se juntaran para celebraciones, que además podían degenerar en una alteración de la convivencia, con las consiguientes molestias para el resto de la población. ${ }^{28}$ Plazas y espacios abiertos eran puntos de encuentro ideales para buscar la oportunidad de mantener relaciones sexuales, juntarse con otros esclavos y celebrar fiestas. ${ }^{29}$ Resulta difícil establecer qué grado de espontaneidad tenían estas reuniones dado que incluso se llevaban instrumentos musicales.

27 Para el ámbito catalán me remito a ARMENTEROS, Iván (2008), "'Si tu non delinquiris'. Conflictividad en torno a la esclavitud en la Barcelona tardomedieval", Anuario de Estudios Medievales, $n^{\circ}$ 38/2, pp. 969-1007; para el ámbito castellano, en el que se centra este epígrafe, el tema se trata con mayor profundidad en GONZÁLEZ ARÉVALO, Raúl (en prensa), "Esclavitud y normativa ciudadana. Dinámicas sociales de integración y exclusión en las ordenanzas municipales de la Corona de Castilla (siglos XV-XVI)", en GUILLÉN, Fabienne y SALICRÚ, Roser (eds.), Être esclave. Dynamiques sociales, identités, acculturation, Casa de Velázquez, Madrid. 
Además, es probable que en los corros también se cantara en árabe o en lenguas del África subsahariana, al igual que está constatado con los negros en las colonias americanas.

Estas fiestas representaban una exclusión en dos sentidos: de una parte, como elemento marginal de la sociedad, la población esclava no participaba en igualdad de condiciones de otras manifestaciones sociales, recurriendo a una vía propia. A su vez, se trata de celebraciones en las que la población libre no tendría cabida, lo que aumentaría el interés de las autoridades concejiles por controlarlas y erradicarlas. Por otra parte, si tenemos en cuenta que la inmensa mayoría de los esclavos de la Península Ibérica habían nacido libres y habían sido esclavizados con posterioridad, es indudable que los corros y cánticos reforzaban la identidad cultural de origen, a la vez que rechazaban la aculturación en una sociedad que tampoco tenía más interés en integrarlos que en someterlos.

La necesidad de controlar el comportamiento de los esclavos llevó a las autoridades a legislar sobre su capacidad de movimiento. No se veía con buenos ojos que la población esclava deambulara a su antojo por la ciudad de día, habiendo espacios en los que estaba expresamente prohibida su presencia, como puertas de las ciudades o alhóndigas de los puertos. Pero con menor razón aún se aceptaba que deambularan de noche, cuando la oscuridad favorecía los delitos. Normalmente los esclavos debían estar ya en sus casas después de la puesta de sol, y sólo se justificaba que salieran de ellas acompañando a sus dueños. En algunas ciudades con un volumen de población esclava importante el ayuntamiento incluso legisló para que los dueños encerraran bajo llave y pusieran cadenas por la noche a sus esclavos, aunque todo parece indicar que la normativa no se cumplió..$^{30}$

28 Para muestra, Jerez de la Frontera, Zafra o Gran Canaria: CARMONA, Ma Antonia y MARTíN GUTIÉRREZ, Emilio (2010), Recopilación de las ordenanzas del Concejo de Xerez de la Frontera. Siglos XV-XVI: Estudio y edición, Publicaciones de la Universidad de Cádiz, Cádiz, p. 392; PERIÁÑEZ, Rocío (2011), Negros, mulatos y blancos: los esclavos en Extremadura durante la Edad Moderna, Diputación Provincial de Badajoz, Badajoz, p. 381; y MORALES PADRÓN, Ordenanzas del concejo de Gran Canaria, p. 106.

29 Así lo confirman las ordenanzas de Granada, Baeza y Llerena: Ordenanzas de Granada de 1552, (1672), edición facsímil, Granada, p. 289; ARGENTE DEL CASTILLO, Carmen y RODRÍGUEZ MOLINA, José (1980), "Reglamentación de la vida de una ciudad en la Edad Media: Las ordenanzas de Baeza", Cuadernos de Estudios Medievales, n VIII-IX, p. 73; PERIÁÑEZ, Negros, mulatos y blancos, p. 277-8. 
De todos los espacios públicos en los que la presencia esclava estaba vedada o condicionada los que indiscutiblemente comparecen de manera recurrente son aquellos relacionados con el vino y el juego. Efectivamente, las ordenanzas destinadas a bodegoneros, mesoneros, venteros y taberneros comparten prohibiciones del mismo tenor: servir vino a los esclavos y darles alojamiento. No es difícil suponer que la combinación de vino y juego derivaría con frecuencia en peleas. $Y$ aunque resulta complicado conocer el alcance del cumplimiento normativo, hay indicios que apuntan a que la población esclava encontró dificultades para acceder a estos establecimientos, lo que le llevó a buscar alternativas fuera de ellos, en casas de vecinos y amigos. ${ }^{31}$

Por lo tanto, se puede afirmar que para la población esclava las tabernas constituían puntos donde socializar con la población libre, que acudía a ellos igualmente a descansar, pasar la noche, beber, comer y jugar. La presencia esclava en estos establecimientos revela un proceso evidente de aculturación, en el que negros y moros asumieron costumbres de la población castellana. Los libres parecen haber compartido espacios y activida-

30 Numerosos ejemplos en Jerez de los Caballeros, Málaga, Gran Canaria, Lepe y Tenerife: PERIÁÑEZ, Negros, mulatos y blancos, p. 453; MARCHANT, Alicia (2002), Los escribanos públicos en Málaga bajo el reinado de Carlos I, Universidad de Málaga, Málaga, p. 82; MORALES PADRÓN, Ordenanzas del Concejo de Gran Canaria, p. 106; GONZÁlEZ GÓMEZ, Antonio (2001), Transcripciones del libro de las Ordenanzas Antiguas de Lepe, Ayuntamiento de Lepe, Lepe, p. 54; Acuerdos del Cabildo de Tenerife. Vol. IV (1518-1525), SERRA RAFOLS, Elías y DE LA ROSA, Leopoldo (edición y estudio) (1970), Instituto de Estudios Canarios, La Laguna, p. 128.

31 Las disposiciones se repiten a lo largo y ancho de la Corona de Castilla: Jerez de la Frontera, Antequera, Murcia, Baeza, Carmona, Zafra, Jaén, Loja, Ronda o Archidona. CARMONA y MARTíN GUTIÉRREZ, Recopilación de las ordenanzas, pp. 359-360; ALIJO, Francisco (1979), Ordenanzas de Antequera (1531), Universidad de Málaga, Málaga, p. 38; MOLINA, "Contribución al estudio de la esclavitud en Murcia", pp. 125-6; ARGENTE DEL CASTILLO y RODRÍGUEZ MOLINA, "Reglamentación de la vida", p. 71; GONZÁLEZ JIMÉNEZ, Manuel (1972), Ordenanzas del concejo de Carmona, Diputación Provincial de Sevilla, Sevilla, p. 121 ; PERIÁÑEZ), Negros, mulatos y blancos, p. 421; RODRÍGUEZ MOLINA, José (1983), "Los no privilegiados en Jaén (siglos XIV y XV)", Hispania, n 155, p. 495; RAMOS BOSSINI, Francisco (1981), Ordenanzas de Loja, Universidad de Granada, Granada, pp. 131-2 y 188; Antiguas Ordenanzas municipales de la ciudad de Ronda, RUIZ POVEDANO, José M. a (introducción y estudio) (2006), p. 213; ESPEJO, Juan Luis y MORALES, Eva (1998), Ordenanzas de Archidona 1598, Universidad de Málaga, Málaga, pp. 71-2. 
des, e incluso acogido esclavos en sus casas, facilitándoles un acceso a la comida y la bebida fuera del ámbito doméstico de los dueños y de los espacios públicos mencionados. Pero el alcoholismo entre la población esclava, calculado en torno al $15-20 \%$ de individuos de media en grandes ciudades como Sevilla, Málaga, Valencia o Barcelona, no se puede considerar una adaptación positiva dentro del proceso de aculturación de los esclavos. Además, la documentación tiene indicios sólidos de que se extendió más entre los negros que entre los moros, tal vez porque las leyes islámicas prohibían expresamente el consumo de alcohol. ${ }^{32}$

Relacionado con la bebida están los otros dos vértices del triángulo de conflictividad social: el juego y el robo. Porque algunos esclavos robaban para jugar y beber. La asociación con los estratos sociales más bajos y la relación con actividades condenadas socialmente como el juego, el robo y la bebida determinó que en última instancia se considerara al individuo privado de libertad un peligro social por sí mismo.

\section{VIDA Y OBRA DE LOS ESCLAVOS}

Con una presencia de esclavos tan sustancial no es difícil imaginar las importantes cifras económicas que se derivaban de su compraventa. Se trataba de una transacción comercial sujetas a las leyes del mercado como cualquier otro producto, determinada por la oferta y la demanda: así, había precios bajos si el mercado estaba saturado, y altos cuando había escasez; del mismo modo, había variables según el "estado de la mercancía", valiendo más los hombres jóvenes y sanos que los niños, ancianos y enfermos. Pero lo más interesante para perfilar los rasgos de esta esclavitud ibérica es conocer el trabajo desarrollado por estos hombres y mujeres esclavizados. ${ }^{33}$

El principal valor que define la esclavitud es el económico. Los beneficios derivados del tráfico de seres humanos y de su rendimiento laboral fueron

32 GONZÁlEZZ ARÉVALO, La esclavitud en Málag, p. 162; FRANCO SILVA, La esclavitud en SeviIla, p. 217; MARZAL PALACIOS, La esclavitud en Valencia, fol. 1082; y ARMENTEROS MARTíNEZ, "'Si tu non delinquiris'”, pp. 989-990.

33 Son fundamentales las reflexiones planteadas por FURIÓ, Antoni, (2000), "Esclaus i assalariats. La funció econòmica de l'esclavitud en la Península Ibèrica a la Baixa Edat Mitjana", en FERRER y MUTGÉ, Esclaus $i$ lliberts, pp. 19-38. Imprescindible asimismo la consulta de los artículos recopilados en el monográfico Treball esclau i treball assalariat a la baixa edat mitjana publicado en 2006 en la revista Recerques: Història, economia i cultura, 52-53. Las aportaciones más recientes en SALICRÚ, Roser (2010), "La explotación de la mano de obra 
la razón de ser de la institución a lo largo de los siglos. Sin embargo, estamos mejor informados sobre el comercio con esclavos -mercados, procedencias, precios- que sobre la verdadera naturaleza y el alcance real de la función económica de la esclavitud medieval. De hecho, esta escasa visibilidad ha conducido a una imagen de improductividad que tradicionalmente ha reducido al esclavo a un objeto de lujo en manos de los grupos sociales más adinerados. De hecho, esta imagen improductiva se extiende al servicio doméstico en general, a pesar de lo cual es irrefutable que la esclavitud como fenómeno era, de manera muy evidente, un fenómeno económico, pues el esclavo era un productor de trabajo y de riqueza, un bien objeto de toda clase de transacciones.

En realidad, el problema del trabajo de los esclavos en general se reduce a tener presente dos premisas fundamentales: la primera, que indiscutiblemente el esclavo formaba parte del grupo doméstico, que hay que considerar como una unidad de producción. La segunda, que las funciones del individuo esclavizado eran tantas cuantas quisiera el amo, ya fuesen productivas o no.

Por otra parte, es complicado constatar las actividades ligadas al ámbito más íntimo de la convivencia porque la documentación pocas veces se refiere a ellas. En primer lugar destacaban las ocupaciones domésticas, entendidas con amplitud de miras: todo lo relativo al interior y el exterior de la vivienda para la convivencia. Las tareas clásicas atribuidas, como ocuparse de la comida y la limpieza, ir al mercado, aprovisionar de agua, lavar la ropa, etc. Algunas de estas actividades se constatan en las ordenanzas municipales que regulaban la convivencia en las ciudades y otras localidades de menor entidad.

Así por ejemplo, se sabe que los esclavos se ocupaban de deshacerse de los desechos domésticos porque no siempre arrojaban la basura en los sitios indicados, sino que a veces, aprovechando la oscuridad de la noche, lo hacían en otros lugares, por la calle o junto a las murallas de las ciudades, con el consiguiente problema de suciedad.

esclava en el Mediterráneo cristiano bajomedieval desde el observatorio catalano-aragonés", Espacio, Tiempo y Forma, Serie III, $H^{a}$ Medieval, n² 23, pp. 167-183; y GONZÁLEZ ARÉVALO, Raúl (2013), "Ordenanzas municipales y trabajo esclavo en la Corona de Castilla (siglos $\mathrm{XV}-\mathrm{XVI})$ ", en CAVACIOCCHI, Schiavitù e servaggio, pp. 431-464. 
Por otra parte, acudir a las fuentes a por agua también podía provocar inconvenientes, en este caso desórdenes. En torno a ellas había esclavos que buscaban encuentros con mujeres, esclavas o no, con los peligros consiguientes porque se podían forzar dichos encuentros, se provocaban peleas y los propios esclavos dejaban de cumplir sus tareas. Por este motivo en muchas ciudades se terminó prohibiendo que los varones esclavizados acudieran a las fuentes públicas.

Entre las tareas relacionadas con la manipulación de alimentos estaba la elaboración y cocción del pan. Pero, además, los esclavos acudían a venderlo al mercado o por las calles. Con frecuencia las autoridades les acusan de cometer fraude, bien vendiéndolo más caro de lo que marcaban las ordenanzas, bien vendiéndolo al precio legal, pero de menor tamaño y peso. También vendían vino, lo que solía causar problemas con el exceso de alcohol, y agua.

Dentro del ámbito doméstico es complicado dilucidar la contribución del trabajo esclavo al artesanado. ${ }^{34}$ Con frecuencia los artesanos tenían el taller dentro de sus viviendas, en el piso inferior que también servía como almacén y tienda, habitando la familia en el piso superior. Se sabe con certeza que los esclavos participaban en el proceso productivo. En la industria textil, por ejemplo, se dedicaban a la limpieza y el hilado de fibras, a su teñido y secado, y a la elaboración de telas tejiendo en telares. Así, es frecuente encontrar esclavos cuyos dueños desarrollan oficios textiles, como roperos, sastres, tintoreros, tejeros y tundidores.

También destacaba el sector del cuero -borceguineros, curtidores, zapateros, guanteros-, seguido de los trabajadores del metal -cuchilleros, herreros, herradores, cerrajeros, armeros, espaderos- y de otros oficios entre los que sobresalían los relacionados con el sector alimenticio: carniceros, vendedores y tratantes de pescado, especieros, bizcocheros y molineros.

En la inmensa mayoría de los casos el reglamento interior de los gremios y cofradías artesanos prohibían que los maestros tuvieran como aprendices a esclavos, probablemente para preservar el monopolio y controlar la competencia. Como mucho, los esclavos ayudaban, pero sin tener un aprendizaje reglado y reconocido. Y desde luego, salvo excepciones, no

34 SALICRÚ, Roser (2009), "Slaves in the Professional and Family Life of Craftsmen in the Late Middle Ages", en CAVACIOCCHI, Simonetta (ed.), La famiglia nell'economia europea. Secc. XIII-XVIII, Firenze University Press, Florencia, pp. 325-342. 
alcanzaban el grado de oficiales, no digamos ya de maestros: era impensable que un esclavo pudiera tener un taller propio e independiente.

Los esclavos también participaban en la construcción, en obras públicas y privadas. Se ha constatado su presencia en atarazanas (Barcelona), catedrales (Barcelona, Tarragona, Mallorca, Sevilla, Málaga) y castillos (Játiva, Tortosa, Bellver y Almudaina de Mallorca, Palacio Real de Barcelona, Reales Alcázares de Sevilla, Alcazaba de Málaga) por todo el territorio. En Cádiz también había población esclava en la obra de la Torre de Hércules o de la Casa de la Sal, por citar sólo unos pocos ejemplos representativos. En las ciudades marítimas es frecuente encontrar varones esclavizados trabajando en el puerto, generalmente cargando y descargando las mercancías y los suministros de los navíos fondeados. Se trataba de trabajos duros, y que en otras ocasiones no quería nadie, como el de verdugo.

Por otra parte, hasta tiempos muy recientes se creía que la esclavitud medieval y moderna era casi exclusivamente urbana. De hecho, algunos autores negaban la presencia de esclavos en el campo. Sin embargo, van saliendo a la luz noticias sobre las actividades de la población esclava en el ámbito rural, donde también desarrollaban actividades domésticas. En este sentido, destaca sobre todas las demás la recogida de leña. Las ordenanzas de los núcleos rurales -Marchena, Zafra, Antequera, Lepe, Carmona, Écija, Ronda-suelen indicar dónde se puede recoger y de qué especies.

Esporádicamente se pueden encontrar algunos testimonios que acreditan labores de labranza entre el trabajo agrícola esclavo, generalmente en las propiedades rurales de los dueños, donde podían participar en la siembra y en la recolecta. Pero el trabajo de campo en los reinos hispanos medievales nunca se basó en la mano de obra esclava, al contrario de lo que sabemos de las grandes plantaciones americanas, donde la extensión y la explotación intensiva requería mucha mano de obra barata, facilitando la supervivencia del fenómeno y su justificación económica.

En definitiva, la población esclava realizaba una función económica complementaria en todos los sectores productivos, variando su importancia y su incidencia en función de factores tan dispares como las condiciones generales del mercado laboral, la oferta y la demanda de mano de obra esclava o el grado de especialización permitido a los individuos privados de libertad, cuya contribución productiva en las sociedades que los esclavizaban es de todo punto indiscutible.

Respecto a la vida en esclavitud, las posturas sobre la naturaleza del trato a la población esclava oscilan entre la benignidad que lo considera casi 
un miembro más de la familia, con una vida nada dura, y la visión sombría del ser humano tratado como un animal, sometido a malos tratos continuos. En este sentido, no cabe duda de que la convivencia permitía el desarrollo de relaciones marcadas por la familiaridad, independientemente de que fueran buenas o malas. Por otra parte, también resulta indudable que se establecían vínculos afectivos, en especial con los menores nacidos en esclavitud en una casa, como revelan muchos testamentos, en los que los dueños incluso se preocupan por el futuro de sus esclavos. Pero una relación larga en el tiempo tampoco garantizaba ni la libertad ni que no se vendieran los esclavos, de modo que el futuro pocas veces estaba asegurado. En cualquier caso, hay que partir de una premisa fundamental: a ninguna persona esclavizada le podía gustar su vida ni su estado, y en consecuencia la propia esclavización ya constituía por sí misma un maltrato a la persona, aunque la mentalidad de la época lo aceptara y la legislación lo sancionara. ${ }^{35}$

\section{Cualquiera podía tener un esclavo}

Frente a la idea extendida de que el esclavo era un objeto de lujo que sólo se podían permitir los grupos sociales más adinerados, lo cierto es que a finales de la Edad Media cualquiera que se lo pudiera permitir podía tener uno. Efectivamente, los datos muestran que los esclavos eran accesibles para toda la sociedad, aunque destacaban como compradores los sectores económicos propios de las sociedades urbanas como médicos, juristas y escribanos, pero sobre todo los relacionados con el comercio y el artesanado. Semejante preponderancia indudablemente estaba relacionada con el carácter doméstico de esta esclavitud urbana y el papel productivo que desarrollaban los esclavos. Por el contrario, resulta más llamativa la posición destacada que llegaban a tener las mujeres como propietarias de esclavos, si bien es cierto que se regían por mecanismos diferentes debido al papel y la posición que ocupaban en la sociedad, lo que confería mayor libertad a las viudas y a las mujeres que estaban solas. ${ }^{36}$

35 En este punto resultan indispensables las consideraciones desarrolladas no hace mucho a partir del caso valenciano en BLUMENTHA, Enemies and Familiars.

36 Para el ámbito castellano véase GONZÁLEZ ARÉVALO, La esclavitud en Málaga, pp. 313 382 , con comparaciones respecto a Sevilla y Granada; para el marco catalano-aragonés, me remito a las consideraciones de ARMENTEROS, L'esclavitud a la Barcelona, pp. 261-321. 
Por lo que se refiere a la oligarquía ciudadana, tradicionalmente presentada como el sector comprador por excelencia, no parece haber tenido la misma importancia en todas las ciudades; el carácter cerrado del grupo ha permitido estudiar no sólo su posición respecto al resto de la sociedad, sino también el grado de penetración de la esclavitud en él, y en algunos casos concretos el resultado ha sido sorprendente por inesperado. Así por ejemplo, en Málaga sólo un tercio de los individuos identificados como pertenecientes a la oligarquía ciudadana era propietario de algún esclavo, y son raros los casos en los que superaban la decena de personas esclavizadas. Por el contrario, en las ciudades de la Andalucía atlántica, con una mayor presencia de la nobleza, había aristócratas que los poseían en abundancia. Aunque se trata de un ejemplo extremo, el duque de Medina Sidonia en 1492 era propietario de noventa y seis esclavos, que aumentaron hasta alcanzar los doscientos cuarenta y ocho, según figura en el inventario de testamentaría de 1507.37

En Sevilla y en Granada junto con la nobleza el otro grupo de grandes compradores fue el de los eclesiásticos. Efectivamente, la Iglesia fue una importante dueña de esclavos, tanto las personas que la integraban como ella misma como persona jurídica. Así, los clérigos de las parroquias, los deanes de las catedrales, obispos, arzobispos y otros clérigos poseyeron esclavos, al igual que conventos y monasterios, en todo el suelo ibérico. La realidad de los hechos es que la Iglesia medieval, lejos de condenar la esclavitud -ya he referido el papel de San Agustín y Santo Tomás de Aquino en la justificación del hecho esclavo- la admitía sin ningún problema y no se observa en su comportamiento nada que indique un trato diferente respecto al resto de la sociedad de la época.

\section{LA QUIMERA DE LA LIBERTAD SOÑADA}

Aunque la esclavitud fuera un hecho aceptado comúnmente por las sociedades medievales, no lo es menos que la libertad estaba considerada el bien más preciado que tenía el ser humano. Así lo consagraba el código de las Siete Partidas de Alfonso X el Sabio de Castilla: "Aman et cobdician naturalmientre todas las criaturas del mundo la libertad, quanto más los homes que han entendimiento sobre todas las otras, et mayormientre aquéllos que son de noble corazón" (Partida IV, Título XXII, Ley I).

37 LADERO QUESADA, Miguel Ángel (1991), "Los esclavos de la casa ducal de Medina Sidonia", en Homenaje a Jacinto Bosch Vilà, Universidad de Granada, Granada, pp. 225-232. 
Sin embargo, la realidad es que, frente a la idea difundida que sitúa la liberación al final de la vida en esclavitud como algo natural y habitual, la mayoría de los esclavos no lograban abandonar su estado, pues el porcentaje de liberaciones era mínimo, como revelan las cifras de los estudios específicos: así, en Sevilla la documentación arroja un porcentaje del 18'5\%, en Málaga un $9 \%$ y en Barcelona un 15\% del total. ${ }^{38}$

La libertad por medios legales se podía conseguir de dos maneras: a través de una manda testamentaria o mediante una carta de ahorría, siendo preceptivo en ambos casos la conversión del esclavo al cristianismo. Pero, como decía, las cifras muestran que no era un acto que estuviera muy extendido. Además, rara vez se hacía sin contrapartida alguna. Así, en los testamentos de ordinario se disponía que el esclavo prestara un servicio durante un número variable de años antes de conseguir la plena libertad, lo que daba lugar a la aparición de la figura designada como criado semilibre.

Por su parte, las cartas de ahorría solían concederse como consecuencia del pago de un rescate, cuya cantidad generalmente era superior al precio de mercado, lo que con frecuencia dificultó la financiación; de hecho, los esclavos que podían permitírselo solían pagarlo a plazos, o tenían que presentar fiadores, lo que muestra las relaciones que tenía fuera del grupo doméstico, pero siempre dentro de los grupos solidarios con el mismo origen etno-geográfico: los negros ayudaban a los subsaharianos y los moros a otros de su raza.

Con respecto a los esclavos que se liberaban, el porcentaje entre negros y blancos estaba bastante equilibrado, aunque las mujeres aventajaban siempre a los varones. El arco de edad es inversamente proporcional al de las compraventas, esto es, predominaban los niños y los adultos mayores de treinta y cinco años. Los motivos que conducían a un dueño a conceder la libertad a un esclavo, al margen de las consideraciones de tipo económico, son variados, destacando dos: el afecto profesado y la falta de convencimiento de la licitud del fenómeno, no obstante la legalidad vigente. Con todo, también había razones más mezquinas, pues, como denunciaba el inmortal Miguel de Cervantes en la segunda parte de El Quijote (capítulo XXIV), también los había que "ahorran y dan libertad a sus negros cuando ya son viejos y no pueden servir, y echándoles de sus casas con título de

38 Así lo confirman los estudios de Alfonso Franco Silva, Raúl González Arévalo e Iván Armenteros Martínez ya citados en este trabajo. 
libres, los hacen esclavos del hambre, de quien no piensan ahorrarse si no es con la muerte".

Más allá del número de liberaciones, cabe destacar que el camino hacia la libertad no era un proceso lineal exento de problemas, pues en ocasiones el dueño se retractaba de su intención, o su entorno no respetaba su última voluntad, manteniendo en esclavitud a quienes en justicia eran libres. Al mismo tiempo, la imagen tópica que pretende que los grupos más acomodados eran más generosos a la hora de otorgar la libertad por su menor necesidad económica se viene abajo cuando descubrimos en un análisis atento que destacaron por su actividad liberadora las mujeres, seguidas de lejos por los miembros de la oligarquía ciudadana, mientras que los demás sectores se mostraron menos proclives a ahorrar -término técnico referido a la liberción- a sus esclavos, probablemente por la capacidad laboral que desarrollaban y el esfuerzo económico que habían sostenido para adquirirlos.

Otro medio para alcanzar la libertad era la fuga, empresa arriesgada, patrimonio en gran medida de los hombres, aunque no parece haber sido una opción generalizada ni mucho menos. ${ }^{39}$ Las razones que impulsaban a un esclavo a huir eran variadas, y hay que tener en cuenta, además de la posibilidad de malos tratos, citada de manera recurrente en la bibliografía disponible, otros factores como el tiempo transcurrido en esclavitud, el grado de integración en el entorno o la poca predisposición del dueño a conceder la libertad a través de los mecanismos legales previstos. En cualquier caso, lo que confirma es que las ansias de libertad de las personas esclavizadas eran irrefrenables, y en última instancia se manifestarían en la negación absoluta de una condición impuesta, así como de los mecanismos legales para salir de ella, y que casi nunca estaban en sus manos. Comoquiera que fuera, aquí cabe hacer una distinción muy fuerte, pues no todos los esclavos tenían las misma opciones de huir y culminar con éxito la empresa. Efectivamente, lo tenían más fácil los moros que los negros por una cuestión geopolítica: mientras el Reino de Granada se mantuvo frente a Castilla (1232-1492) fue la tierra prometida de la libertad para los esclavos moros que lograban alcanzarlo tras huir de los lugares donde les

39 En Málaga los esclavos fugados en 1487-1538 supusieron el 2'5\% del total, mientras que en Granada en todo el siglo XVI no superaron el $4^{\prime} 5 \%$. Estos datos y las conclusiones que le siguen proceden fundamentalmente de GONZÁLEZ ARÉVALO, Raúl (2014), "Ansias de libertad. Fuga y esclavos fugitivos en el Reino de Granada a fines de la Edad Media", en MARTíN CASARES, Aurelia (ed.), Esclavitudes hispánicas (siglos XV-XXI), Universidad de Granada, Granada, pp. 105-130. 
retenían esclavizados. Por el mismo motivo, la conquista del emirato nazarí y la necesidad de cruzar el Mediterráneo occidental para llegar al Magreb volvió la empresa más ardua, aunque los musulmanes de la tierra-mudéjares primero, moriscos después de la conversión forzada al cristianismo en el siglo XVI-garantizó la ayuda de los correligionarios en el intento por alcanzar el Norte de África. La nueva frontera marítima y la mayor cercanía de las costas ibérica y magrebí en el Mar de Alborán convirtió a Málaga y Almería en puntos obligados para dar el último salto hacia la libertad.

No cabe duda de que los negros lo tenían más difícil. Su propio color de piel delataba el origen esclavo. Tampoco tenían población libre en la que apoyarse, a diferencia de los moros. Por último, la lejanía de los territorios de origen, el África subsahariana, hacía prácticamente imposible que pudieran regresar a su casa, sin olvidar que muchos de ellos habían sido vendidos como esclavos a los tratantes portugueses por tribus rivales o como consecuencia de guerras intestinas, de modo que ni siquiera tenían una casa a la que regresar.

Cuando un esclavo huía se iniciaba un procedimiento para recuperarlo, con frecuencia largo, complejo y en muchas ocasiones gravoso, y sin garantía de éxito final. El dueño denunciaba su desaparición ante la justicia para conseguir una carta en la que las autoridades municipales o judiciales acreditaran que había denunciado el hecho y solicitaba la colaboración institucional para recuperarlo. Pero antes debía demostrar que el esclavo era suyo.

Una vez obtenida la fe, el dueño podía reclamar personalmente el esclavo. Sin embargo, lo más habitual parece haber sido otorgar una carta de poder para que otro realizara la búsqueda. Estos documentos recogían habitualmente nombre y edad del esclavo, color de piel, rasgos físicos concretos -tatuajes, defectos, enfermedades y minusvalías-, los hierros que pudiera llevar y la indumentaria con la que huyó, de modo que todo condujera a la identificación positiva del esclavo. Generalmente se ignora la fecha exacta de la fuga, siendo más habitual que se hable de días, semanas, meses e incluso años. Así, había auténticos profesionales dedicados a la caza y captura de esclavos fugados.

También se daban ejemplos de lo que hoy día se define como "colaboración ciudadana", en el que la población daba noticia de esclavos fugados, cuando no los capturaban y los entregaban a las autoridades personalmente. Sin duda dos eran los motivos que respaldaban esta acción: la necesidad de mantener el orden social establecido, en el que los esclavos tenían que aceptar el lugar que la sociedad que les esclavizaba les había 
otorgado y la codicia o la necesidad económica: la captura tenía un valor tasado, una recompensa.

\section{SOBREVIVIR AL ESTIGMA DE LA ESCLAVITUD: LOS LIBERTOS}

La liberación de los esclavos, por escaso que fuera su porcentaje, dio lugar a la aparición de un nuevo grupo social, los libertos, aunque su rastro es extremadamente difícil de seguir porque prácticamente desaparecen de la documentación. ${ }^{40}$

En teoría los libertos podían obrar igual que el resto de la sociedad libre. La realidad demuestra que la práctica era otra. En cualquier caso, parece claro que lo primero que hacían era conformarse una identidad nueva para comenzar su integración en la sociedad de acogida, ahora como una persona libre. Dicha integración comprendía varios aspectos, como eran aprender bien la lengua, culminar la conversión religiosa y asumir los comportamientos sociales propios de la sociedad en la que se desenvolvían.

Sin duda alguna, uno de los pilares básicos de esta integración se realizaba a través del trabajo. En este sentido, resulta indiscutible la importancia del papel del amo, de cuyas decisiones es deudora la trayectoria del futuro liberto, pues estaba condicionado por la propia visión del propietario, que decidía aprovechar o no el tiempo en esclavitud para proporcionarle una formación profesional -aunque sólo fuera en beneficio propio- que contribuiría de manera innegable a la asimilación en el nuevo marco socio-económico. En caso positivo, el antiguo dueño se convertía en un factor decisivo que ayudaba al liberto en su nuevo objetivo.

Es de suponer que estos antiguos esclavos intentarían ejercer una vez alcanzada la libertad, pero sus aspiraciones chocaban con las normativas gremiales, que con frecuencia prohibían a los libertos desempeñar los oficios que habían aprendido, o que ingresaran en sus filas. Con todo, no es menos cierto que, en los casos mejor estudiados como Barcelona, había un grupo que constituía lo que podríamos entender como un proletariado no asimilado por las corporaciones gremiales, en el que se integraban muchos

40 Ineludible en este punto el trabajo de PLAZOLLES, Fabienne (2000), "Trayectorias sociales de los libertos musulmanes y negroafricanos en la Barcelona tardomedieval", en FERRER y MUTGÉ i VIVES, Esclaus i lliberts, pp. 135-150. En el mismo volumen se puede consultar FRANCO SILVA, Alfonso (2000), "Los negros libertos en las sociedades andaluzas entre los siglos XV al $X V I^{\prime \prime}$, pp. $51-64$. 
libertos que trabajaban sin contrato, de forma que resulta imposible seguirles la pista. Por su parte, en Sevilla había negros grumetes o cargadores de barcos, mientras que otros se empleaban como albañiles, carpinteros o zapateros, e incluso como aprendices de otros oficios cuya normativa no sería tan restrictiva. Y, naturalmente, estaba el servicio doméstico, en el que se desempeñaban hombres y mujeres como criados y escuderos al servicio de las oligarquías ciudadanas. No hay demasiadas referencias sobre la soldada que ganarían, pero todo apunta a que el jornal pagado no difería en exceso del que cobrarían los trabajadores libres no cualificados.

Los escasos testamentos conservados muestran que los libertos vivían muy modestamente. Con frecuencia vestían ropas heredadas de sus antiguos amos, era raro que poseyeran una vivienda en propiedad y parece claro que muchos tuvieron que afrontar problemas económicos, hasta el punto que algunos terminaban en la cárcel por deudas. La dificultad para encontrar trabajo e ingresos abocaría a comportamientos delictivos, y en el caso de las mujeres hay testimonios que confirman que algunas ejercieron la prostitución, probablemente para sobrevivir.

Así pues, la vía de integración en las sociedades ibéricas por medio del trabajo era extremadamente difícil. En consecuencia, la supervivencia pasaba por establecer relaciones personales de otro tipo, fundando una familia o integrándose en una cofradía. Aunque son muy pocos los matrimonios constatados entre libertos, todo apunta a la endogamia. Efectivamente, los antiguos esclavos se casaban con otros que generalmente compartían la misma posición social e idéntica condición jurídica, además de un mismo origen etno-geográfico. $Y$ desde luego hubo uniones personales sin vínculo consagrado por la Iglesia. En cualquier caso, parece claro que la constitución de la familia se retrasaba a causa de la esclavitud, pues aunque el vínculo afectivo fuera previo a la liberación, por lo general los libertos se casaban una vez ahorrados. También podría ser la explicación para la baja tasa de natalidad, menor aún entre las libertas que entre las esclavas. Tal vez haya que encontrar aquí una explicación biológica: muchas de las esclavas eran ahorradas con el encargo de buscar o que se les buscara marido. Si la liberación llegaba a una edad relativamente avanzada-como de hecho ocurría habitualmente, sobre todo si no mediaba el pago de un rescate- las posibilidades para concebir se verían reducidas progresivamente. Un dato revelador en este sentido proviene de las partidas bautismales, en las que apenas encontramos hijos de libertos nacidos con posterioridad a su ahorramiento. En consecuencia, aunque escasas en número, lo más habitual es encontrar parejas de libertos sin descendencia. 
Otros, los menos, entraban en comunidades religiosas que, sin duda, aseguraban la supervivencia en libertad.

Respecto a las cofradías, parecen haber sido una vía preferente para los subsaharianos, y son ampliamente conocidas las cofradías de negros de Valencia y Barcelona en el siglo XV. ${ }^{41}$ En la Corona de Castilla destaca la cofradía de negros de Sevilla, si bien se conoce mejor su desarrollo ya en la Edad Moderna. ${ }^{42}$ Sin duda su existencia respondía a la voluntad de integrarse en una estructura contemplada por la sociedad medieval.

No es difícil imaginar que los moros libertos se dirigían a tierras del Islam -el Reino de Granada, el Magreb- para vivir en libertad, de ahí la ausencia generalizada de noticias sobre ellos. Por el contrario, el menor interés de los subsaharianos por regresar a sus lugares de origen se ha relacionado con el temor a ser reducidos a esclavitud una segunda vez, sin descartar que en esas sociedades la condición esclava, aunque hubiera sido temporal, fuera una marca indeleble. Asimismo, no se puede descartar que la posición social en las sociedades ibéricas, por difícil que resulte imaginarlo, fuera mejor que en las nativas. De cualquier forma, lo cierto es que a partir del siglo XVI muchos negros libertos emigraron desde Sevilla al Nuevo Mundo, buscando trabajo y, probablemente, un futuro mejor, lo más alejado posible del pasado esclavo y del estigma servil.

41 GUAL CAMARENA, Miguel (1955), "Una cofradía de negros libertos en el siglo XV", Estudios de la Edad Media en la Corona de Aragón, n 5, pp. 457-466; BLUMENTHAL, Debra (2005), "La Casa dels Negres: black African solidarity in late medieval Valencia", en EARLE, Thomas F. y LOWE, Kate J. P. (eds.), Black Africans in Reinassance Europe, Cambridge University Press, Cambridge, pp. 225-246; ARMENTEROS, Iván (2011), "Un precedente ibérico de las hermandades de negros", en DALLA CORTE, Gabriela, JORDÁN, Pilar, LAVIÑA, Javier, MORAGAS, Natàlia, PIQUERAS, Ricard, RUIZ-PEINADO, José Luis y TOUS, Meritxell (coords.), Sociedades diversas, sociedades en cambio. América Latina en perspectiva histórica, Universidad de Barcelona, Barcelona, pp. 143-150; ARMENTEROS, Iván (2012), "De hermandades y procesiones. La cofradía de esclavos y libertos negros de Sant Jaume de Barcelona y la asimilación de la negritud en la Europa premoderna (siglos XV-XVI)", Clio - Revista de Pesquisa Histórica, Pernambuco, n 29/2, 2012 [consulta 16 de junio de 2019: http://www.revista. ufpe.br/revistaclio/index.php/revista/article/view/234].

42 MORENO, Isidoro (1997), La antigua hermandad de los negros de Sevilla: Etnicidad, Poder y Sociedad en 600 años de Historia, Universidad de Sevilla, Sevilla. 
Los libertos que permanecían en territorio ibérico también buscaron adquirir la condición de vecinos en las ciudades en las que estaban arraigados. En Sevilla, por ejemplo, contrataban casi inmediatamente después de obtener la libertad un procurador o personero que defendería sus intereses, muy especialmente los referentes a su propia libertad cuando se cuestionaba, lo que desembocaba generalmente en un pleito, aunque no parece que hayan sido numerosos. De hecho, hay constancia de libertos apresados bajo el pretexto de que en realidad eran esclavos.

\section{Esclavitud ibérica medieval y Memoria Histórica}

En definitiva, resulta imposible negar el alcance de la presencia esclava en la España medieval, a la cabeza de Europa occidental. Su importancia se refleja en la documentación conservada, referente sobre todo a las compraventas, el trabajo esclavo y la convivencia con la sociedad libre. Este mismo patrimonio documental ha contribuido a generar una serie de imágenes como la del hombre-animal, que como todos los estereotipos esconden una realidad histórica infinitamente más compleja y rica. La complejidad al fin y al cabo que tiene toda historia con seres humanos como protagonistas.

Como en el caso de la Memoria Histórica de la Guerra Civil y la represión franquista, es responsabilidad de la sociedad rescatar y reconocer el pasado esclavista ibérico en época bajomedieval. Es tarea de los historiadores sacarlo fuera de los círculos académicos y difundirlo, al igual que se está haciendo en otras sociedades como la estadounidense, y como intenta auspiciar la UNESCO. 



\title{
¿SERVIR CON LA PLUMA? EL EFECTO ESPEJO EN EL AUSTRIAS CARMEN DE JUAN LATINO
}

\author{
TO SERVE WITH THE PEN: THE MIRROR EFFECT IN \\ JUAN LATINO'S AUSTRIAS CARMEN
}

\author{
Maxim Rigaux \\ University of Chicago
}

\section{RESUMEN}

En este ensayo destaco cómo Juan Latino (ca.1518-ca.1595), antiguo esclavo de la ilustre familia Fernández de Córdoba, crea una persona literaria compleja a través de sus dos volúmenes de poesía publicadas en 1573 y 1576 en Granada. Prestaré atención especial a la manera en que Latino establece un efecto espejo en el Austrias Carmen, un poema épico de dos cantos en latín que celebra la victoria cristiana en la batalla de Lepanto. Este recurso literario le da la oportunidad de fijar la atención no solo en su mecenas Pedro de Deza, pero también en su propia figura como poeta único. Compararé las estrategias textuales de Latino con el uso del efecto espejo en Las Meninas de Diego Velázquez.

Palabras clave: Juan Latino, Literatura neolatina, Autorrepresentación, Efecto espejo, Las Meninas.

\begin{abstract}
This article highlights how Juan Latino (ca. 1518-ca. 1595), a former black slave of the illustrious Fernández de Córdoba family, creates a highly complex literary persona through the two volumes of Latin poetry he published in the 1570s in Granada. I will pay special attention to Latino's staging of a mirror effect in the Austrias Carmen, a two-book epic on the Christian victory in the battle of Lepanto. This technique enables the poet to place his patron Pedro de Deza at the centre of attention alongside his own authorial figure. In my analysis, I will compare Latino's textual strategies to Diego Velázquez's use of the mirror in Las Meninas.
\end{abstract}

Keywords: Juan Latino, Neolatin poetry, Self-fashioning, Mirror effect, Las Meninas. 


\section{RESUM \\ ¿SERVIR AMB LA PLOMA? L'EFECTE ESPILL EN EL AUSTRIAS CAR- MEN DE JUAN LATINO}

En aquest assaig destaque com Juan Latino (ca. 1518 - ca. 1595), antic esclau de la il.lustre família Fernández de Córdoba, crea un personatge literari complex a través dels seus dos volums de poesia publicats en 1573 i 1576 en Granada. Atorgaré una especial atenció a la manera en què Latino estableix un efecte espill en el Austrias Carmen, un poema èpic de dos cants en llatí que celebra la victòria cristiana en la batalla de Lepant. Aquest recurs literari li permet de fixar l'atenció no sols en el seu mecenes Pedro de Deza, sinó també en la seua pròpia figura com a poeta únic. Compararé les estratègies textuals de Latino amb la utilització de l'efecte espill a Les Menines de Diego Velázquez.

Paraules clau: Juan Latino, literatura neollatina, autorepresentació, efecte espill, Les Menines. 
Juan Latino, antiguo esclavo del tercer duque de Sessa, nos asegura en sus dos volúmenes de poesía, publicados en Granada respectivamente en los años 1573 y 1576, que Pedro de Deza, presidente de la Real Audiencia y Chancillería de Granada, le encargó escribir las dos obras.' Sin embargo, lo encargado por Deza -o sea, la epopeya Austrias Carmen de la primera obra y los epitafios de la segunda- se extendió con poemas adicionales que se dedican a Felipe II y a diferentes personas ilustres y relacionadas con la corte del rey, como también al propio Gonzalo Fernández de Córdoba en la segunda obra sobre el traslado de los cuerpos reales a El Escorial. Llama nuestra atención cómo Latino, poniendo a estas personas juntas en un mismo volumen de poesía, es capaz de crear una relación afectuosa entre todos ellos. Particularmente, a través del uso de la figura retórica del apóstrofe, establece una conexión fuerte entre Deza y la Casa de Austria en la primera obra. ${ }^{2}$ De este modo, Latino parece cumplir con un tópico

1 Para la biografía más reciente y completa del autor, véase MARTíN CASARES, Aurelia (2016), Juan Latino: talento y destino, Universidad de Granada, Granada. Sobre el contexto histórico y social de la Granada de aquella época, véanse los análisis detenidos de SÁNCHEZ MARTíN, José Antonio y MUÑOZ MARTíN, María Nieves (2009), "El Maestro Juan Latino en la Granada renacentista. Su ciudad, su vida, sus protectores", Florentia Illiberritana, n² 20, pp. 227 260, y WRIGHT, Elizabeth (2016), The Epic of Juan Latino. Dilemmas of Race and Religion in Renaissance Spain. University of Toronto Press, Toronto, pp. 21-83.

2 RIGAUX, Maxim (2016), "Casting the Reader as Eyewitness: Apostrophe and Visualization in Juan Latino's Austrias Carmen (1573)", Hispanic Review, Pennsylvania, n 84/4, pp. 405 425. En este artículo se examina cómo el uso recurrente del apóstrofe a Pedro de Deza no solo aumenta el efecto de visualización de lo narrado, sino también establece una relación afectuosa entre Deza y el héroe-protagonista Don Juan de Austria. 
recurrente en los prefacios de la poesía épica hispánica: el de servir "con la pluma". ${ }^{3}$ En este artículo, profundizaré el análisis del uso de esta estrategia literaria que le sirve al narrador para fijar la atención en Deza. Mi hipótesis es que Latino provoca con esta figura retórica un efecto espejo en su Austrias Carmen que se puede comparar con lo que ocasiona Diego Velázquez en Las Meninas por medio de la representación de un espejo al fondo de la tela con la imagen un poco borrosa de los reyes españoles. Concretamente, demostraré que este efecto espejo se manifiesta especialmente en un episodio clave del poema épico donde el héroe-protagonista Don Juan interpreta las palabras de Deza en un discurso hacia los capitanes de la Santa Liga después de la victoria en la batalla de Lepanto 7 de octubre de 1571).

Tal y como Velázquez se representa de manera enfática a sí mismo en Las Meninas, es evidente que Latino se auto-promociona continuamente en su obra literaria. El apóstrofe en el poema épico es tan solo una de las muchas estrategias utilizadas por el poeta para recalcar su propia figura. Aunque los dos libros se arraigan fuertemente en un contexto local -el de las festividades y ceremonias en la Granada de los años setenta del siglo XVI- por lo que la poesía tiene un objetivo claramente celebrativo y al servicio de la Monarquía Hispánica, no cabe duda de que el verdadero motivo de Latino era su propia promoción como el poeta ideal de Felipe II. Así, además de una cubierta con el escudo real que está rodeado de epígrafes en latín, las dos obras tienen un frontispicio con dedicatoria principal al Católico Rey Felipe (Ad Catholicum Philippum). Más aun, la primera parte del volumen de 1573 se distingue por los dos poemas dirigidos directamente a Felipe II. Aparte del poema épico, éstos son los poemas que han recibido la mayor atención de la crítica moderna. ${ }^{4}$ El primer poema, una elegía de 78 versos, - 36 dísticos, se destaca por la autorrepresentación -o self-fashioning-del poeta como etíope cristiano. El segundo, un epigrama de 20 versos, o 10 dísticos, ha sido interpretado por Christopher Maurer como la inspiración

3 Para una discusión de este tópico en muchos de los prólogos de la poesía épica hispánica, véase VEGA, María José (2010), "Idea de la épica en la España del Quinientos", en VEGA, María José y VILÀ, Lara (coords.), La teoría de la épica en el siglo XVI (España, Francia, Italia y Portugal), Editorial Academia del Hispanismo,Vigo, pp. 115-131.

Véanse FRA-MOLINERO, Baltasar (2005), "Juan Latino and His Racial Difference.", en EARLE, Thomas F. y LOWE Kate. J. P. (coords.), Black Africans in Renaissance Europe, Cambridge University Press, Nueva York, pp. 326-344; MAURER, Christopher (1993), "Un monarca, un imperio y una espada: Juan Latino y el soneto de Hernando de Acuña sobre Lepanto", Hispanic Review, Pennsylvania, ${ }^{\circ} 61 / 1$, pp. 35-51; y WRIGHT, The Epic of Juan Latino, pp. 97-112. 
fundamental de un soneto afamado en España por su conexión con el régimen franquista: el soneto de Hernando de Acuña con el verso célebre "Un monarca, un imperio y una espada". ${ }^{5}$

En el primer poema, la elegía, Latino destaca su ambición literaria, presentándose como el poeta único de la Casa de Austria y comparándose explícitamente con Don Juan de Austria, el triunfador único en la historia. Además, desde el inicio del poema, destaca su color negro e identidad de etíope cristiano como un aspecto llamativo e incluso exótico. Relaciona su propia singularidad como poeta etíope con la de Don Juan como vencedor del imperio Otomano. Su autorrepresentación como etíope y negro no es gratuita en absoluto, sino muy bien pensada. ${ }^{6}$ Elaborando una inversión irónica de la narrativa bíblica del bautizo del eunuco etíope de la reina Candace por el apóstol Felipe, Latino trata de convencer al rey Felipe de que su propia existencia es como un don divino que no puede rechazar:

Non temere Aethiopi coelo datus ergo Philippus, Ne Aethiopi iusta haec forte Philippe neges.

No por casualidad al etíope fue ofrecido por el cielo Felipe; así, no niegue sin más a este etíope lo que merece, Felipe. ${ }^{7}$

Así como el encuentro entre el eunuco etíope, tesorero de la reina Candace, y el apóstol Felipe no es casual, tampoco es accidental el del rey Felipe II con el poeta etíope Latino. Después, Latino alude también a la idea de

5 MAURER, "Un monarca, un imperio y una espada". Sin embargo, esta interpretación, a mi modo de ver, ha vuelto a estar puesto en tela de juicio recientemente. Véase el artículo de DíEZ FERNANDO, José Ignacio (2011), "La inspirada poética del soneto Al rey, nuestro señor, de Hernando de Acuña", Hispanic Review, n 79/4, pp. 527-546.

6 En su análisis detenido de esta elegía, Baltasar Fra-Molinero destaca la importancia de esta identificación de Latino con la Etiopía bíblica. La considera como una estrategia retórica por la cual Latino se quiere distinguir categóricamente del grupo étnico de los moriscos. Véase FRA-MOLINERO, "Juan Latino and His Racial Difference, pp. 336-338.

7 Juan LATINO, Ad Catholicum, fol. 10r. Traducción mía. Siempre cito del ejemplar original del primer volumen que se encuentra hoy en día en la Biblioteca Universitaria de Granada, CJC_86; salvo en el caso de la epopeya, por la cual utilizo la edición y traducción de José Antonio SÁNCHEZ MARÍN: véase infra n. 12. 
que siempre ha sido una costumbre de reyes (mos regum) tener elementos exóticos en sus palacios. Todo ello, por supuesto, sirve para inmortalizar al rey y su dinastía.

Latino no solo se representa como el nuevo poeta de Felipe II, sino que también resalta su relación con su mecenas local, Pedro de Deza, el que da cierta coherencia a la obra entera. Después de varios poemas laudatorios ajenos que sirven para aumentar la autoridad del poeta, Latino presenta un primer epigrama de su propia mano (de catorce versos y dirigido al lector): se trata de una breve descripción de introducción a la persona Deza. El epigrama preliminar sirve como prueba del enorme cariño que siente Deza por la Casa de Austria. El último dístico le caracteriza como un confidente del rey (fidus regis):

Nam fidus regis meditatur grandia: princeps

Floreat, et frater carmine doctiloquo.

Porque un confidente del rey medita sobre cosas grandes:

que florezcan el príncipe y su hermano por la elocuente poesía. ${ }^{8}$

Sin embargo, el 'fidus regis' puede referirse tanto al mecenas Deza como al poeta Latino que escribió la poesía de este volumen. Es imprescindible observar, ya aquí en este primer poema, cómo Latino hace hincapié en su propio papel decisivo para revelar los servicios reales de su mecenas.

Vuelve la figura de Deza al final de la primera parte del volumen de 1573. Se trata de un poema en el que Latino se dirige directamente a su mecenas. Anticipa el tono dialógico del siguiente poema épico, que se caracteriza por el uso frecuente del apóstrofe. Aquí el poeta le ofrece a Deza el poema encargado de una manera fuertemente visual:

Ecce tibi Austriades prodit iam, Deza, legendus, qui victor pelagi dicitur esse ducum.

¡Mira! Ya te aparece, Deza, a tí, para ser leído, el Austríades, el que, según se dice, es el triunfador de los capitanes en el mar. ${ }^{9}$

8 Juan LATINO, Ad Catholicum, fol. 5 r.

9 Juan LATINO, Ad Catholicum, fol. 44v. 
Esta visualización se puede entender de diferentes maneras. Primero, por la disposición de los folios en el volumen, Latino alude al nuevo frontispicio con el escudo de armas de la familia Deza y con el nuevo título que anuncia el Austrias Carmen. De esta manera, la visualización se hace concreta cuando se refiere a la materialidad del libro mismo. Segundo, el "Austríades" es una clara alusión al héroe del poema, Don Juan, quien aparece ante los ojos del lector como en el teatro. El verbo 'prodire' tiene aquí el doble sentido de 'pasar adelante' $y$ 'salir a escena'. La idea del poema épico como la lectura de una obra teatral o, aún más, de una representación literaria de una batalla ficticia que formara parte de las festividades en Granada nos hace comprender mejor las estrategias literarias de Latino. Latino destaca la figura de su mecenas a lo largo de todo el poema épico a través de un exordio extenso y un uso recurrente del apóstrofe a Deza. Estas interrupciones de la narrativa sirven para motivar a Deza, en particular, y al lector, en general, a imaginarse la descripción visual del poeta. Estos momentos de interrupción ocurren sobre todo cuando el autor describe episodios de fuerte emoción o dramatismo, como la primera aparición de Alí Bajá, el enemigo turco, o la violencia durante la batalla naval. Elizabeth Wright ha interpretado estos episodios de manera subversiva: como una crítica (casi enigmática) del poeta contra su mecenas por la actuación implacable de éste hacia los moriscos durante la Guerra de las Alpujarras. ${ }^{10}$ En esta guerra civil, se le atribuye en gran parte al presidente de la Real Chancillería Pedro de Deza la rebelión de los moriscos, por su "manera de proceder [...] con esta gente," según las palabras del propio Don Juan de Austria en una carta a su hermano Felipe II. ${ }^{11} \mathrm{Es}$, pues, muy probable que Deza le encargara a Latino este poema sobre la victoria de Don Juan en la batalla naval de Lepanto contra el Imperio Otomano como una manera de mejorar su imagen y de hacer auto-propaganda.

El apóstrofe resalta el interés de Deza no solo por la Casa de Austria, sino también por la fortuna de los moriscos. Así, se puede entender mejor el episodio más curioso de la epopeya, es decir, la escena en la cual Don Juan pronuncia un largo discurso a los capitanes destacados de la Santa Liga. Después de haber observado algunas de las acciones más crueles de toda la batalla, Don Juan empieza a anticipar la reacción futura de Pedro de

10 Véase, sobre todo, WRIGHT, Elizabeth (2009), "Narrating the Ineffable Lepanto: The Austrias Carmen of Joannes Latinus (Juan Latino)", Hispanic Review, Pennsylvania, n 77/1, pp. 71-92, en particular pp. 76-77.

11 En CARO BAROJA, Julio (2000 [1976]), Los moriscos del Reino de Granada. Ensayo de historia social. Istmo, Madrid, p. 157. 
Deza cuando escuche éste la noticia de la victoria de Lepanto en Granada. El poeta-narrador interrumpe el discurso, nada menos que tres veces, para hacer hincapié en las palabras de Don Juan sobre Deza:

Imprimis te, Deza, suum dum laudat amicum, quae tibi vitarit narrare pericula gestit. Ad proceres versus repetebat, Deza, subinde: 'Quid nunc noster,' ait, 'faceret, iam Deza per urbem si nunc Hispanos victores crederet unus? Obvius, ut ridens nobis occurreret ille fortunasque meas, fratris nomenque Philippi aequaret caelo, vultu acceptissimus omni.'

Al mismo tiempo que te alaba sobre todo a ti, Deza, amigo suyo, arde en deseos de narrar los peligros que te evitó; vuelto a los generales, Deza, decía a continuación: "¿Qué haría nuestro Deza ahora por la ciudad -dijo- si fuera el único en saber vencedores a los hispanos? Como riendo con su rostro tan grato a todos, saldría a nuestro encuentro, levantaría hasta el cielo mi buen hado y el nombre de mi hermano Felipe ${ }^{\prime \prime}{ }^{12}$

Se podría decir que Deza se convierte en el verdadero protagonista del poema. Lo que importa es la reacción emotiva de Deza, no solo en este momento, sino también a lo largo del poema a través de los apóstrofes recurrentes. Sin duda alguna, el clímax de este proceso es cuando don Juan imita las palabras de Deza y (casi) se identifica con él:

'Est famulus regi fidus promptusque Philippo.

Argumentum ingens mentis, quae ad regia nata est:

«Pellebam haereticos, Mahumeti et crimina sectae, scindere dum propero non iam medicabile vulnus, sinceras partes purgataque oppida peste $[\ldots]^{\prime \prime \prime}$

12 Juan LATINO, Austrias Carmen, vv. 1382-89 [Liber II]. Utilizo siempre la traducción española de SÁNCHEZ MARÍN, José Antonio (1981), La Austriada de Juan Latino. Introducción, traducción inédita y texto, Universidad de Granada, Granada, p. 143. 


\begin{abstract}
"Es un súbdito fiel y diligente para con su rey Felipe, prueba evidente de su inteligencia que nació para acciones reales: 'Yo rechazaba a los herejes y los crímenes de la fe de Mahoma, en tanto que me apresuro a separar de las partes sanas la herida ya incurable, y las ciudades purificadas de esta peste $[\ldots]^{\prime \prime} .^{13}$
\end{abstract}

Cuando Deza como lector primero y principal del poema épico lee estas últimas palabras, lee, en realidad, su propio discurso y se ve a sí mismo reflejado. Este efecto espejo es similar a lo que ocurre, por ejemplo, en Las Meninas de Diego Velázquez. El comitente de la pintura, el rey Felipe IV, se ve a sí mismo y a la reina consorte, Mariana de Austria, en el espejo que está al fondo de la pintura. Sin embargo, el retrato de los reyes ocupa un lugar central, a la misma altura de los ojos del espectador. De la misma manera, Deza se ve a sí mismo en un momento clave, como el de la repetición de sus propias palabras por el héroe-protagonista, sin olvidarse de todos los apóstrofes a lo largo del poema, que tienen -en retrospectiva- un efecto similar.

El poema épico de Latino trata en primer lugar de la reacción visual y emotiva del lector a los versos del poeta. Muchas de las descripciones son ambiguas y dejan la interpretación del lector abierta. De la misma manera, se ha observado que uno de los atractivos más fuertes del cuadro de Velázquez es su ambigüedad interpretativa, la cual se debe en gran medida al hecho de que el punto de la mirada del espectador sea variable y-por consecuencia- también lo es la interpretación de la pintura. ${ }^{14}$ Cada interpretación depende de la perspectiva del espectador que asume el papel más importante en el cuadro. En el poema de Latino es el lector quien asume el papel más importante. De hecho, a través del uso recurrente del apóstrofe, el lector es alentado a que visualice la descripción verbal del narrador y medite sobre lo que ve con el ojo de la mente. Al mismo tiempo, según la retórica clásica, este estado de enargeia convida también a la admiración del ingenio del poeta-orador. ${ }^{15}$ En efecto, el hecho de que el lector admire

13 Juan LATINO, Austrias Carmen, vv. 1394-98 [Liber II], p. 143.

14 La bibliografía entorno a esta pintura es casi infinita. Me limito aquí a referir a la obra de BROWN, Jonathan y en particular a su Velázquez: Painter and Courtier,Yale University Press, New Haven, 1986. Además, quiero destacar las reflexiones sobre Las Meninas como una meta-metaimagen en MITCHELL, William J. T. (1994), Picture Theory: Essays on Verbal and Visual Representation. The University of Chicago,Chicago \& London, pp. 58-64.

15 Por ejemplo, QUINTILIANO dice en sus Instituciones Oratorias que a través de la enargeia uno es capaz de tener ante sus ojos la imagen inicial del poeta-orador. Véase PLETT, Heinrich F. 
la situación descrita se debe a la mano del escritor quien puso no solo su mecenas en el centro de la atención -si bien en el espejo al fondo,- sino también su propia figura y su manera ingeniosa de retratar las cosas.

La ambigüedad de la interpretación es particularmente fuerte en las representaciones del remero morisco y del capitán turco Alí Baja. Aquí, el narrador intenta arrancarle al lector, en primer lugar Deza, una reacción emotiva y luego interpretativa de la descripción. En segundo lugar, cada lector está invitado a reflexionar sobre su propia reacción a la imagen lastimosa del Otro y a juzgar la actitud de Deza contra los moriscos. Deza, el primer lector y así también testigo del procedimiento de escritura del poeta, se convierte en otro objeto representado. Por eso, el presidente Deza -formando parte del espectáculo implícito que crea el narrador, primero, a través de la imaginación de Don Juan y, segundo, para los demás lectores que lean las escenas caracterizadas por el apóstrofe de una manera diferente-acapara toda la atención. La pregunta que procede automáticamente de estas observaciones es -lógicamente- la siguiente: j̇cuál es la imagen que se tiene de Deza después de leer el poema épico?

La respuesta a esta pregunta es compleja ya que el poema es deliberadamente ambiguo. Véamos el ejemplo más significante del primer libro de la epopeya: la representación -rara en los poemas de Lepanto- de un remero morisco de la Santa Liga. No cabe ninguna duda de que el poeta quiere provocarle al lector una reacción emotiva por medio del episodio fuertemente visual. Antes de dirigir la atención a un remero morisco individual, Latino le presenta a Deza la importancia de los remeros para el éxito de la Liga: "Éste es el mérito esencial de la flota, ésta es su fuerza, su poderío, Deza". ${ }^{16}$ Luego, el poeta-narrador describe que un cierto capitán cristiano le mete miedo al remero morisco, quien está observando, entre temor y esperanza, a sus amigos turcos en el otro campo. El lenguaje amenazante del capitán anónimo hacia uno de los remeros moriscos nos hace compartir los sentimientos de miedo de un morisco cautivo. La última imagen que Latino pinta de él nos hace comprender su victimización:

Impellens dulcis patriae reminiscitur agros, cui mors aut summo libertas danda periclo.

(2012), Enargeia in Classical Antiquity and the Early Modern Age: The Aesthetics of Evidence, Brill, Leiden, pp. 7-21.

16 Juan LATINO, Austrias Carmen, v. 386: "Haec classis virtus, haec vis, haec, Deza, potestas". El énfasis es mío. Nótese la triple repetición en el original latín del pronombre deíctico 'haec'. 
Mientras rema, recuerda los campos de su amada patria, quien ha de alcanzar la muerte o la libertad a cambio del mayor peligro. ${ }^{17}$

Esta imagen del morisco recordando su patria alude a una imagen similar que se encuentra en el modelo principal de Latino, la Eneida de Virgilio.

De hecho, en el décimo libro de su epopeya, Virgilio representa una imagen dolorosa de Antores, una figura secundaria que aparece una sola vez en todo el poema. ${ }^{18}$ Es llamativo por varias razones. Primero, el poeta deplora la muerte de un compañero de Evandro, rey de los arcadios. Antores, antiguo compañero de Hércules, se unió a Evandro después de haberse marchado de Argos. Se observa que murió, desgraciadamente, herido por una lanza dirigida hacia otra persona. ${ }^{19}$ La lanza que mató a Antores vino de la mano de Mezencio, quien quería arduamente vengarse de Eneas por la muerte de su hijo Lauso. En otras palabras, esta alusión a la muerte de Antores sugiere que se debería interpretar de una manera similar la muerte del remero morisco durante la batalla naval. El morisco se ha convertido en una víctima indefensa e inocente. Segundo, la frase a la que alude Latino es, precisamente, la que utiliza Quintiliano como ejemplo acertado en su discusión de enargeia. Quintiliano sostiene que el poeta romano tenía ante el ojo de la mente una imagen de la muerte. ${ }^{20}$ Tercero, esta alusión en un episodio caracterizado por el apóstrofe y la fuerte visualización revela muy bien el arte poético de Latino. Demuestra cómo el poema épico es una representación de una representación clásica a la que señala por medio del uso del apóstrofe. El Austrias Carmen es un meta-metapoema, o sea, el equivalente verbal de la práctica visual de Velázquez's Las Meninas.

Además de la función metapoética de este y otros episodios similares en el poema, no se puede negar que el efecto espejo estimula también al lector a hacer una autorreflexión. Existe quizás la tentación de interpretar la representación compasiva del remero morisco como un elemento de crítica en el texto. Sin embargo, me parece poco probable que un erudito y futuro cardenal como Pedro de Deza, quien estudió derecho en el Colegio Viejo de San Bartolomé de Salamanca y fue un verdadero mecenas de las artes, no solo en Granada, sino también más tarde durante su larga estancia en

17 Juan LATINO, Austrias Carmen, v. 417-18. He modificado ligeramente la traducción aquí, porque creo que luce más fuerte el impacto del episodio si se traduce el sujeto de la escena -el remero morisco (remex Maurus)- en el singular.

18 VIRGILIO, Eneida, X.781-82: "Caelumque / aspicit et dulcis moriens reminiscitur Argos».

19 VIRGILIO, Op. cit., X.781: "Sternitur infelix alieno vulnere". El énfasis es mío.

20 QUINTILIANO, Instituciones Oratorias, VI.II.32. También PLETT, Enargeia, pp. 179-81. 
Roma, ${ }^{21}$ no entendiera los mensajes subversivos del poeta Latino, si éste hubiera sido el caso. El hecho de que se publicaran las dos obras de Latino me parece prueba decisiva de que a Deza le agradó la poesía del poeta etíope y -por consiguiente- también la representación lastimosa del remero morisco y del capitán turco. Son imágenes que, en efecto, conmueven y estimulan a una meditación religiosa de la situación política.

No hay que olvidar tampoco que en la Historia del rebelión y castigo de los moriscos del reino de Granada (1600), una obra que se considera como la más propagandística de las tres que se han escrito sobre las guerras civiles en las Alpujarras, ${ }^{22}$ Luis del Mármol Carvajal observa frecuentemente que el presidente Deza dio muestras de compasión con los moriscos. El mejor ejemplo es la respuesta que da Deza a los moriscos después del famoso discurso de Francisco Núñez Muley, cuando éste defendió los hábitos y las prácticas socio-culturales de los moriscos como reacción a la Pragmática Sanción de 1567: "El presidente le respondió [a Núñez Muley] que todo cuanto él pudiese hacer para que los vasallos de Su Majestad no fuesen molestados lo haría". ${ }^{23}$ Asimismo, se repite una y otra vez que Felipe II no quería que se murieran los moriscos, sino que se convirtieran y fueran buenos vasallos. Deza concluye así su discurso a Núñez Muley: "Concluyó con decirle resolutamente que Su Majestad quería más fe que farda y que preciaba más salvar una alma que todo cuanto le podían dar de renta los moriscos nuevamente convertidos". ${ }^{24}$ La idea de la conversión (en vez de muerte) de estos moriscos también aparece varias veces en la obra de Latino. En la epopeya, se impone la idea sobre todo en la muerte deplorada de Alí Bajá. El narrador observa explícitamente que si no hubiera muerto, Alí Bajá, un personaje admirado por los soldados cautivos y cristianos por su virtud cristiana, se habría convertido sin ninguna duda a la fe católica. ${ }^{25}$

21 Para una breve introducción a las actividades de Deza en Roma, desde 1578 hacia su muerte en 1600, véase el libro de DANDELET, Thomas James (2001), Spanish Rome, 1500-1700. Yale University Press, New Haven, pp. 98-101 y passim.

22 Al lado de la Historia de Mármol Carvajal, existen dos otras crónicas en las que se narra la Segunda Guerra de las Alpujarras: la Guerra de Granada de Diego Hurtado de Mendoza y las Guerras Civiles de Granada de Ginés Pérez de Hita.

23 MÁRMOL CARVAJAL, Luis de (2015), Historia de rebelión y castigo de los moriscos del reino de Granada. Estudio, edición, notas e índices de Javier Castillo Fernández, Universidad de Granada, Granada, p. 130, II. 10. En cuanto a la cita, refiero primero a la página de la edición moderna y luego al libro y el capítulo según la división tradicional.

24 MÁRMOL CARVAJAL, Historia de la rebelión y castigo, p. 131, II. 10. 
No es mi intención poner en tela de juicio las consideraciones historiográficas en cuanto a la postura hostil de Deza para con los moriscos. Existen suficientes pruebas de que Deza se comportaba de forma intolerante con ellos. El mejor ejemplo lo encontramos sin duda en las palabras de Don Juan en una carta a su hermano Felipe. ${ }^{26}$ Sin embargo, rechazo la tesis de que Latino hubiera intentado reprenderle a Deza su conducta con su poema épico a través del uso del apóstrofe en los episodios más dramáticos. Dicho de otro modo, rechazo la tesis de que fuera la única interpretación posible del poema. Por esa razón, es tan imprescindible el papel del lector como el que da significado al poema. El efecto espejo tiene como primer resultado que el lector se da cuenta de su propia respuesta a ciertas descripciones y que las interpreta. Por consiguiente, es posible que Deza interpretara estas situaciones como afirmativas de su actitud justificada para con los moriscos y que le gustara el poema épico como un medio de propaganda acertado. La centralidad de Deza se confirma, además, en el primer poema después de la epopeya: una peroración según las reglas de la retórica clásica, dirigida a Deza. En este poema, Latino describe el actual estado feliz (status foelix) de Granada, gracias a los esfuerzos del presidente Deza. Sin embargo, Latino apela en su primer volumen de poesía también a otras personas cercanas al ámbito del rey. Por ejemplo, hay poemas preliminares dirigidos a Antonio Gracián de Alderete Dantisco, secretario de Felipe II, a Luis Manrique, Capellán y Limosnero Mayor de la Capilla Real, y a Diego de Espinosa, presidente del Consejo de Castilla e Inquisidor General de España. Latino seguramente tiene en mente a estas personas poderosas cuando expresa por medio de Don Juan el deseo de que ellos fueran testigos de la batalla naval: "él como general deseaba que todos estuvieran presentes, los jefes hispanos, los grandes y poderosos del reino, para que Espinosa, cabeza de los pueblos en el reino de su hermano, y el Consejo Real contemplasen sus muy ilustres hazañas" ${ }^{27}$

25 Juan LATINO, Austrias Carmen, vv. 1207-13 [Liber II], pp. 130, y en particular versos 1207. 08: "Y si por azar hubiese sido capturado vivo en el combate, hubiese bebido la fe de Cristo a causa de su extraordinaria virtud." Se repite esta idea también frecuentemente en la segunda obra de Latino, De Augusta translatione. Granada: Hugo de Mena, 1576. Véase, por ejemplo, el siguiente comentario que se puede leer en una nota marginal del folio $28 \mathrm{v}$. (como parte de la primera elegía dirigida a Don Gonzalo Fernández de Córdoba): "Philippus nec Maurorum, nec Turcarum nec ludaeorum mortem desiderat, sed ut convertantur, et vivant".

26 Véase más arriba la nota 11.

27 Juan LATINO, Austrias Carmen, vv. 1374-80 [Liber II], pp. 141-43. El énfasis es mío. 
Para terminar, quiero ilustrar otro ejemplo de esta estrategia literaria a través de la cual Latino relaciona su servicio con el de ilustres personas cercanas al rey. Esta vez es un ejemplo del segundo volumen de 1576, en el que Latino conmemora el traslado de los cuerpos reales de la Capilla Real de Granada a El Escorial de Felipe II en el invierno de 1573-1574. En este libro, lleno de epitafios, incluye también dos elegías dirigidas a su antiguo maestro Gonzalo Fernández de Córdoba. En la primera, Latino hace una descripción elegante tanto del traslado de los cuerpos reales como de la 'querella' de la Granada personificada. ${ }^{28}$ Lo que me interesa destacar ahora es la manera en que Latino relaciona este traslado real con el que realizó Don Gonzalo en los años 1550, cuando éste trasladó, desde Italia a España, los cuerpos difuntos de sus padres, los segundos duques de Sessa. Según la nota al margen de este poema, la decisión de Felipe II para trasladar a varios miembros de su familia ennobleció (nobilitavit) también al tercer duque de Sessa. Latino le sirve a su antiguo dueño inmortalizando y conectando estos dos traslados 'con su pluma'. Como Deza en el poema épico, el duque de Sessa recibe toda la atención apareciendo al inicio de esta elegía sobre el traslado de los cuerpos reales. En el caso de Deza, es Don Juan quien ilustra a la persona del mecenas, mientras que en el caso de Don Gonzalo es el propio Felipe II quien ennoblece al antiguo dueño de Latino. Pero, al fin y al cabo, el lector se asombra, más que nada, del ingenio del poeta, quien sabe unir los nobles con la Casa de Austria en una relación afectuosa.

En conclusión, hemos visto cómo Latino consigue emplear un lenguaje de servicio para invertir los papeles y recalcar su propio talento como poeta ingenioso. En la epopeya, Latino celebra la victoria de la Casa de Austria en la batalla de Lepanto y sabe vincular su mecenas Deza al héroe don Juan en una relación afectuosa. Aún más, consigue centrar toda la atención en Deza a través de un uso recurrente del apóstrofe. Latino, pues, sirve en la primera obra sobre todo los intereses de su mecenas y en la segunda -aunque en menor grado- también los de su antiguo dueño Don Gonzalo. Al mismo tiempo, el servir con la pluma no significa que Latino no haga resaltar su propia persona. Lo hace, como hemos visto, explícitamente en la elegía preliminar dedicada a Felipe Il y también -aunque a primera vista de forma mucho más implícita- en el poema épico, donde a través del efecto espejo destaca su labor e ingenio, así como hace Velázquez en su

28 Sobre la figura retórica de prosopopoeia y la figura de Granada en el volumen de 1576, véase RIGAUX, Maxim (2018), "Prosopopoeia in the Funeral Poetry of Juan Latino", eHumanista: Journal of Iberian Studies, $n^{\circ} 39$, pp. 248-260. 
autorretrato en Las Meninas. El carácter fuertemente metapoético del poema épico se intensifica sobre todo en las escenas más dramáticas donde se utiliza no pocas veces el apóstrofe a Deza. Esta estrategia retórica y literaria lleva a la característica ambigüedad del poema en cuanto a cómo interpretar las escenas dramáticas, porque deja la interpretación de éstas abierta y en manos del lector. El lector, pues, asume el papel más importante en el poema épico de Latino, similar al papel del espectador en la pintura de Velázquez. Por desgracia, ya no podemos saber las respuestas de Deza y Felipe II durante su lectura de los libros de Latino, y en especial del Austrias Carmen, pero el hecho de que se publicaran parece indicar que les agradaron a los dos. 



\title{
ESCLAVOS Y CRIADOS: METÁFORAS VISUALES Y MUNDOS IMAGINARIOS
}

\section{SLAVES AND SERVANTS: VISUAL METAPHORS AND IMAGINARY WORLDS}

\author{
Sandra Martínez Rossi \\ Universidad de Málaga
}

\section{RESUMEN}

Los mundos imaginarios vinculados a la representación de la esclavitud exigen una mirada analítica que considere la antropología de la imagen y su semiótica. Los elementos visuales transforman los espacios, las personas y las relaciones sociales y mediante determinados enlaces simbólicos cada personaje se ubica en una zona del cuadro. Criados y esclavos representan desde la metáfora un espacio social liminal mientras que los reyes y nobles asumen el control de la imagen.

La piel como superficie simbólica manifiesta su rango a través del imaginario, una hiperrealidad que exacerba las diferencias entre el ámbito doméstico y/o esclavizante y el hábitat monárquico.

Palabras clave: Imagen, antropología, jerarquía, esclavitud, nobleza.

\section{ABSTRACT}

The imaginary worlds linked to the representation of slavery demand an analytical look that considers the anthropology of the image and its semiotics. The visual elements transform spaces, people and social relationships and through certain symbolic links each character is placed in an area of the painting. Servants and slaves represent from the metaphor a liminal social space while kings and nobles assume the control of the image.

The skin as a symbolic surface manifests its range through the imaginary, a hyperreality that exacerbates the differences between the domestic and / or enslaving environment and the monarchical habitat.

Keywords: Image, anthropology, hierarchy, slavery, nobility. 


\section{RESUM}

\section{ESCLAUS I CRIATS: METÀFORES VISUALS I MONS IMAGINARIS}

Els mons imaginaris vinculats a la representació de l'esclavitud exigeixen una mirada analítica que tinga en consideració l'antropologia de la imatge i la seua semiòtica. Els elements visuals transformen els espais, les persones i les relacions socials, i mitjançant enllaços simbòlics concrets cada personatge s'ubica en una zona del quadre. Criats i esclaus representen des de la metàfora un espai social liminal al mateix temps que els reis i nobles assumeixen el control de la imatge. La pell com superfície simbòlica manifesta el seu rang a través de l'imaginari, una hiperrealitat que exacerba les diferències entre l'àmbit domèstic i/o esclavitzant i l'hàbitat monàrquic.

Paraules clau: Imatge, antropologia, jerarquia, esclavitud, noblesa. 
El presente artículo sustenta su análisis en la antropología de la imagen, es decir, en la interpretación de las representaciones artísticas teniendo en cuenta el contexto sociológico y antropológico en el cual el discurso visual tiene lugar. Esta visión antropológica centra su atención en los sujetos y cómo las imágenes sirven para activar los mecanismos de poder, un particular punto de vista que se aleja del estudio histórico y formal de las obras de arte. Al respecto, de acuerdo con las investigaciones de Hans Belting, nos interesa pensar en términos visuales y no circunscribir el concepto de imagen únicamente al ámbito artístico, en palabras de este autor: "(...) la perspectiva antropológica fija su atención en la praxis de la imagen, lo cual requiere un tratamiento distinto al de las técnicas de la imagen y su historia". ' En relación a las obras artísticas que analizaremos, si bien los elementos iconográficos empleados imprimen a la cultura visual características fijas inherentes a cada época, también funcionan como puntos de inflexión de la semiótica de la imagen y activan en el propio espacio simbólico el tránsito hacia una transformación social de las personas esclavizadas. De este modo, durante este proceso se genera otra imagen la cual, como afirma Hans Belting: "(...) sólo podrá tener el efecto de una nueva porque utiliza un medio nuevo, o porque reacciona a una nueva praxis de la percepción". ${ }^{2}$

En este sentido, los mundos imaginarios se erigen como metáforas visuales del mundo real y en el caso que nos ocupa la representación de la esclavitud exige una mirada analítica que contemple la antropología de la imagen, para ello si bien el objetivo fundamental del análisis es hallar los mensajes ocultos o escamoteados en el seno del discurso visual, resulta imprescindible tener presente que en el ámbito ficcional las diferentes interpretaciones abren un abanico de otros objetivos posibles. Es decir, desde

1 BELTING, Hans (2007), Antropología de la imagen, Katz Editores, Buenos Aires, p. 10.

2 BELTING, Antropología de la imagen, p.69. 
un punto de vista semiótico las imágenes siempre acogen el concepto de metáfora como un medio para explicar -y justificar- los mundos imaginarios que expresan y a través de los cuales se crean las bases simbólicas de las diferentes esferas de la realidad.

Para desplegar esta lectura metafórica establecemos cinco metáforas, por un lado, resulta clave el estudio de los elementos visuales más importantes que se hallan implicados en la composición de las obras analizadas, por otro lado, proponemos analizar cómo la simbología de la mirada implícita en las representaciones pictóricas es dirigida a través de cada recurso compositivo y, por último, creemos relevante puntualizar que el color de la piel es una característica simbólica determinante en el esquema de la composición. De este modo, la primera metáfora se refiere al uso de la luz, la segunda se halla asociada al espacio que ocupa cada personaje en la escena representada, la tercera está en relación a la organización tanto de los elementos iconográficos como de los sujetos protagonistas de la composición y cómo este cambio se verá reflejado en una transformación de los paradigmas sociales, la cuarta está íntimamente ligada a la anterior ya que el análisis detalla el momento en el cual los libertos asumen un rol protagónico tanto en su vida social como artística y, por último, la quinta metáfora visual de alguna manera pretende cerrar el círculo y llegar a una reflexión final que permita abrir el debate sobre la situación de la esclavitud como proyección de una realidad contemporánea.

El punto de partida de este artículo son las representaciones visuales de criados, criadas, esclavos y esclavas en el ámbito europeo durante los siglos XVI y XVII, algunas de estas obras se enmarcan en un periodo significativo de la pintura española, cuando la imágenes renacentistas y religiosas dan paso al Barroco, donde todo fluye y confluye en la luz. El claroscuro, en ocasiones bajo la impronta del tenebrismo, transforma los espacios, las personas representadas y las relaciones sociales entre ellas. Este uso formal y expresivo de la luz enmarcado en esta etapa artística ha sido ampliamente estudiado y no es la intención de este análisis desplegar los conceptos en esa línea, pero sí cabe destacar planteamientos desde otra perspectiva complementaria y no hegemónica que se adecúa más a nuestra propuesta como la idea de "lo barroco" desarrollada por Eugenio y Angel D'Ors o los diferentes ensayos sobre el Barroco escritos por Severo Sarduy que proponen una perspectiva descentrada del Barroco europeo en el contexto sudamericano. ${ }^{3}$ Ambos autores ofrecen una mirada

3 D'ORS, Eugenio y D'ORS, Ángel (2002), Lo barroco, Tecnos, Madrid; y SARDUY, Severo (1987), Ensayos generales sobre el Barroco, FCE, Buenos Aires. 
introspectiva, literaria, filosófica y sociológica del Barroco que excede la época histórica y de cuyos estudios podríamos extraer un cierto carácter antropológico. Estos puntos de vista conectan con nuestro interés en reflexionar sobre el campo lumínico como metáfora de los cambios sociales acontecidos en relación a la esclavitud, y cómo los contrastes de luz son elementos móviles dentro de la representación y proporcionan a las figuras un sentido simbólico específico.

La conexión -o desconexión- visual entre los protagonistas de las obras pictóricas se produce como metáfora de un espacio social liminal, un término utilizado por Arnold Van Gennep y retomado por el antropólogo Victor Turner al referirse a las distintas etapas del proceso ritual, ${ }^{4}$ la fase liminal respondería a ese momento de indeterminación simbólica del sujeto hasta que se consuma la iniciación, un espacio que este autor relaciona con la oscuridad e invisibilidad "estructural" del individuo durante la ceremonia.

La primera metáfora visual que proponemos se ajusta a esta idea, en parte porque el uso de la luz específicamente en las obras pictóricas donde aparecen retratadas personas esclavizadas o sirvientes sirve para reforzar su imperceptible realidad social. En este sentido, en estas representaciones la luz destaca los espacios y provoca intensos contrastes intrínsecamente asociados al color de la piel de cada personaje de la escena, a partir de los matices lumínicos cada uno es ubicado no sólo dentro del espacio pictórico sino que también es "proyectado" al lugar que asume en el estrato social.

De las imágenes se extraen diferentes aspectos que estructuran la composición, en primer lugar, las luces y sombras se utilizan para representar la jerarquía de cada sujeto y en segundo término, gracias a este efecto la figura encarnada en nobles, reyes o reinas adquiere todo el protagonismo. Aquí la reflexión de Severo Sarduy sobre el Barroco aporta una visión muy interesante:

Arte de la argucia: su sintaxis visual está organizada, en función de relaciones inéditas: distorsión e hipérbole de uno de los términos, brusca noche sobre el otro; desnudez, ornamento independiente del cuerpo racional del edificio, adjetivo, adverbio que lo retuerce, voluta: todo artificio posible con tal de argumentar, de presentar autoritariamente, sin vacilaciones, sin matices. Todo por convencer. ${ }^{5}$

4 TURNER, Víctor (1988), El proceso ritual: estructura y antiestructura, Taurus, Madrid, p. 101.

5 SARDUY, Ensayos generales sobre el Barroco, p. 151. 
Un grado de convencimiento que puede advertirse en la mirada de los personajes de la escena cuya proyección organiza la lectura simbólica de la obra, por un lado, los ojos de los esclavos/as o criados/as se hallan intencionalmente dirigidos hacia el interior del espacio representado, al contrario, su amo/a mira hacia el exterior de la representación, es decir, al entorno real. Bajo esta trama, la propia antropología de la imagen está en sintonía con la realidad social, ya que los focos lumínicos y las zonas de penumbra articulan los mundos visibles del cuadro y, en consecuencia, dejan claro desde la metáfora el status social de las personas representadas. En relación al análisis de Victor Turner sobre fase liminal del ritual, ${ }^{6}$ este primer punto establece una conexión visual y simbólica relevante entre la oscuridad del cuadro y la marginalidad e invisibilidad social implícita en la propia condición de esclavitud. Esta asociación simbólica incluso se mantiene fuera del ámbito artístico en la sociedad contemporánea ya que el concepto de "nocturnidad" es atribuido a la juventud cuya vida liminal se mueve en el ámbito nocturno y al margen de la sociedad actual. Según Bárbara Belloc, ${ }^{7}$ estas características se relacionan con un momento de indeterminación, una etapa que atraviesan los jóvenes durante el rito de iniciación a la vida adulta. Traemos a colación esta similitud entre momentos históricos antagónicos en parte porque consideramos oportuno aplicar este estado ritual a los niños y las niñas que aparecen en los retratos de mujeres de la nobleza o realeza, es decir, nos resulta primordial analizar la situación liminal como significante de una parte del proceso de iniciación hacia la propia liberación del esclavo o esclava, un recorrido que en términos artísticos va paulatinamente de la sombra a la luz, pero que a su vez se erige como metáfora de la verdadera transformación social que experimentarán las personas esclavizadas en busca de respeto y reconocimiento. En esta fase liminal, a diferencia de la juventud contemporánea que elige de forma voluntaria el hábitat nocturno para transitar al margen de la sociedad, los esclavos y las esclavas que se retratan en diferentes obras pictóricas de los siglos XVI y XVII se "instalan" involuntariamente a la sombra de su señor o señora.

En esta línea, los sujetos que representan una mayor jerarquía en la sociedad (reyes, reinas, nobles, mercaderes, etc.) suelen emerger en los cuadros como focos de luz en sí mismos, destacando no sólo dentro de la composición sino también evidenciando ese contraste social con sus esclavos/as o

6 TURNER, El proceso ritual: estructura y antiestructura, p. 101.

7 BELLOC, Bárbara (1998), Tribus porteñas, conejillos de indias y blancos ratones: un breviario de zoología urbana, Libros Perfil, Buenos Aires, pp.13-18. 
criados/as a través del color y la luz, incluso en algunos casos, la extrema iluminación les proporciona un halo divino como en las pinturas religiosas de periodos precedentes.

Este grado de jerarquización que la sociedad de la época presentaba en el campo pictórico y especialmente a través de la luz podemos apreciarlo en el Retrato de Laura Dianti realizado por Tiziano aproximadamente entre 1520 y 1525, que actualmente forma parte de la Colección Heinz Kisters. Por aquellos años, casi se podría decir que se había puesto de moda tener como pajes niños o niñas de piel negra, que le otorgaban un aire de exotismo al ambiente aristocrático o monárquico y que eran muy apreciados en las cortes europeas, ${ }^{8}$ una estima que solapaba un interés etnocéntrico por lo exótico. En esta obra vemos a una pequeña niña de tez negra observando a su señora, esta mirada hacia el espacio interior de la representación "retiene" su figura en ese mundo imaginario y, al mismo tiempo, desde la metáfora visual confirma que su existencia "real y simbólica" se halla determinada por su ama. Luce diversos ornamentos y una vestimenta suntuosa, muy característicos de quienes están al servicio de mujeres de alto status social, ${ }^{9}$ detalles que manifiestan notorias diferencias con otras criadas o esclavas, sin embargo, la semejanza del color de la piel con el fondo del cuadro la relega simbólicamente a su condición de servidumbre o esclavitud.

Por otra parte, si tenemos en cuenta que la lectura e interpretación de cualquier imagen se ejecutan desde la zona izquierda de la representación, la ubicación de la niña en la parte lateral, inferior y derecha del cuadro, es decir, en el último punto del recorrido visual, donde la mirada se detiene y la contemplación de la obra concluye, refuerza aún más el lugar social y simbólico de cada una de las figuras. Por un lado, el de inferioridad de la pequeña, ${ }^{10}$ y por otro lado, el de superioridad de Laura Dianti, quien asume el rol protagónico en ambos sentidos, no sólo porque ocupa el espacio central de la composición y su silueta es de mayor tamaño -independientemente de que las medidas de cada personaje estén justificadas por tratarse de un adulto y una niña-, sino también porque mira al espectador, encarnado en el propio artista. Cuando cada observador/a entra a la escena pictórica por el lateral izquierdo se establece un primer contacto visual a

8 LOWE, Kate (2012), "The lives of Africans slaves and people of African descent in Renaissance Europe", en SPICER, Joaneath (ed.), Revealing the african presence in renaissance Europe, Walters Art Museum, Baltimore, p. 17.

9 LOWE, "The lives of Africans slaves", p.20.

10 LOWE, "The lives of Africans slaves", p. 17. 
través del cruce de miradas con la protagonista, que sincrónicamente simboliza una conexión explícita de Laura Dianti con el mundo exterior. Además, el esquema seguido por el artista en cuanto a la ubicación y tamaño de los personajes responde a la jerarquía y subordinación de las figuras protagonistas en las obras renacentistas, sobre todo en aquellas imágenes de carácter religioso.

Una representación similar se puede observar en el cuadro Retrato de Juana de Austria, realizado por el pintor portugués Cristóvão de Morais aproximadamente en el año 1555, durante su estancia como pintor activo de la corte portuguesa entre los años 1551 y 1573, una obra que en la actualidad se encuentra en el Museo Real de Bellas Artes de Bélgica. En esta pintura, como bien afirma Almudena Pérez de Tudela Gabaldón: "(...) existe un marcado contraste entre la perfección real y la imperfección del esclavo", 11 esta oposición potencia la estructura jerárquica y se ve claramente reflejada en el uso de la iluminación como metáfora visual de esa disparidad, el hecho de destacar el rostro y la mano de la protagonista como los únicos puntos de luz y, por lo tanto, de claridad, en contraste con la oscuridad general del cuadro es un recurso que atrapa toda la atención del público.

En cuanto al color de la piel, desde el Renacimiento los tonos claros, la textura tersa y el aspecto luminoso se atribuían a las personas de clase aristocrática o de la realeza, por el contrario, la piel negra se interpretaba como signo de corrupción en relación a la blancura original, ${ }^{12}$ en consecuencia, la piel morena u oscura se erigía como representante de las clases bajas y trabajadoras, cuya tonalidad fue asociada inicialmente al efecto de la exposición prolongada a la luz solar, ${ }^{13}$ en gran parte, esta sobreexposición estaba vinculada a los trabajos agrícolas o de otro tipo realizados en el exterior de los palacios por esclavos/as o criados/as; asimismo, el negro por motivos obvios se relacionaba con el color de la piel de esclavos y esclavas de origen africano. Desde el siglo XV hubo un gran interés por medir la luminosidad de la piel y así, poder establecer desde un punto de vista científico una escala de valores donde la piel blanca ocupaba el primer lugar y la piel negra el último; si bien esta valoración con medios técnicos

11 PÉREZ DE TUDELA GABALDÓN, Almudena (2017), "Esclavos y criados en la corte del rey Felipe II" [ponencia inédita], en Jornadas Internacionales Esclavos y Criados de Nobles y Reyes en España s. XVI y XVII, Palacio de la Madraza, Granada, s. p.

12 MARTíNEZ ROSSI, Sandra (2017), La piel como superficie simbólica. Procesos de transculturación en el arte contemporáneo ( $2^{a}$ ed. actualizada), FCE, Madrid, p. 37.

13 SPICER, Joaneath (2012), "European perceptions of blackness as reflected in the visual arts", en SPICER, Revealing the african presence, p.36. 
recién se pudo llevar a cabo más adelante, indiscutiblemente la creación de estos niveles tenía claras connotaciones racistas. ${ }^{14}$ En definitiva, el personaje "negro" en las obras pictóricas simbolizaba el elemento exótico y, precisamente, el color oscuro de su piel y su mimesis, en algunos casos, con las zonas de oscuridad del cuadro producían un mayor destaque de la "blancura" de su amo, ${ }^{15}$ y por consiguiente, este contraste ponía de manifiesto la condición de superioridad del sujeto blanco y occidental.

Retomando el análisis del retrato de Juana de Austria, podemos decir que se produce el mismo circuito visual a través de las miradas que en el retrato de Laura Dianti y aporta un significado equivalente: el pequeño mira a su señora, estableciéndose un diálogo interno cuya simbología respalda su dependencia social hacia ella y, por otra parte, Juana de Austria mira una vez más al espectador. Con respecto a la ubicación de los personajes, a pesar de que el paje está ubicado a la izquierda y debería ser la primera figura observada, su diminuto tamaño y su camuflaje con el fondo hacen que su silueta sea casi imperceptible y la mirada del observador se posa directamente en los ojos de la protagonista.

En relación a esta obra, Almudena Pérez de Tudela Gabaldón comenta que existía un vínculo fuerte y afectivo entre los pequeños y sus señoras, ${ }^{16}$ y en los cuadros analizados este nexo queda manifiesto por la posición de las manos de las protagonistas, ya que Laura Dianti apoya su mano sobre el hombro de la niña y Juana de Austria la posa sobre la cabeza de su pequeño paje, otorgando, si cabe, un sentido maternal o de protección a la representación. Asimismo, la posición de las manos en actitud de deferencia y cariño continúa apreciándose a finales del XVII en otros retratos similares como el Retrato de Lovise de Kérovaille realizado por Pierre Mignard, y el retrato de Mademoiselle de Blois y Mademoiselle de Nantes realizado por Philippe Vignon. Nuevamente podemos observar la presencia de niños y niñas de origen africano como pajes de aristócratas y reinas, expresión de exotismo que seguía el mismo patrón compositivo: personajes principales jerarquizados y gran contraste lumínico entre las figuras. En el caso del retrato de las hijas de Luis XIV ejecutado por Philippe Vignon, llama la atención de manera sobrecogedora la similitud formal y cromática entre el niño negro y el perrito que sostiene entre sus brazos Mademoiselle de Nantes, ambos destacan por su intensa negrura y su ojos saltones, con un cierto tinte caricaturesco. Dicha asociación se puede interpretar en concordancia

14 MARTÍNEZ ROSSI, La piel como superficie simbólica, p.37.

15 MARTÍNEZ ROSSI, La piel como superficie simbólica, p.43.

16 PÉREZ DE TUDELA GABALDÓN, "Esclavos y criados". 
con el pensamiento de la época, ya que por aquellos años la visión occidental con respecto a los sujetos exóticos venidos de otras tierras estaba ligada al mundo animal y salvaje. Además, resulta sintomático que en la gran mayoría de las pinturas los pajes, criados y criadas representados no se mencionen en el título de la obra, no obstante, la ausencia de esta referencia cambiaría años después.

Los elementos visuales construyen la imagen y la piel se transforma en superficie simbólica, convirtiéndose, una vez más, en testigo de las circunstancias que rodean al imaginario. Como afirma Jean Paul Sartre, el imaginario se halla ligado a la imaginación, que es activada de manera consciente a través de la imagen que como tal es un objeto irreal, sin embargo, este autor afirma: "toda consciencia es consciencia de algo". ${ }^{17} \mathrm{Se}-$ gún Sartre, "cada consciencia postula su objeto", ${ }^{18}$ a sabiendas de que al tratarse de una imagen el objeto-sujeto real no está ahí, pero pese a todo le proporcionamos existencia, queremos creer que es así, aunque sepamos de manera plenamente consciente que no existe. ${ }^{19}$ En este sentido, relacionando esta idea con el análisis visual que se propone en este artículo, las imágenes poseen un significado contradictorio, irónico y poco inocente de la realidad representada, creándose en ellas "una actitud funcional", ${ }^{20}$ es decir, que las representaciones sirven a un cometido específico: ser recreaciones de un determinado contexto real, expresiones de un hipertexto que aumenta las desigualdades entre el ámbito doméstico y/o esclavizante y el hábitat monárquico o noble.

Esta hiperrealidad propone a través de las imágenes ir más allá con el fin de crear otra realidad que enfatice según la mirada de aristócratas y monarcas los aspectos positivos y neutralice los elementos negativos $y$, al mismo tiempo, proponga soluciones desde un punto de vista simbólico a las desigualdades sociales y culturales de la época. Esta estrategia simbólica ha sido utilizada en grupos étnicos sudamericanos como los caduveo y según el análisis de Lévi Strauss la asimetría de los diseños de los tatuajes pretendía equilibrar la división tan marcada de la sociedad caduveo. ${ }^{21}$ En cuanto a las pinturas analizadas y referidas a la esclavitud, la iluminación excesiva en las manos de las mujeres retratadas destacando cualidades

17 SARTRE, Jean Paul (2004), The Imaginary: A Phenomenological Psychology of the Imagination, Routledge, Londres, p. 11.

18 SARTRE, The Imaginary, p. 12.

19 SARTRE, The Imaginary, p. 14.

20 SARTRE, The Imaginary, p. 16.

21 LÉVI-STRAUSS, Claude (1970), Tristes Trópicos, Eudeba, Buenos Aires [citado en MARTíNEZ ROSSI, La piel como superficie simbólica, p.108] 
de empatía y cariño hacia su esclavo o esclava, al igual que su rostro iluminado alegando un halo de santidad podrían interpretarse en la misma dirección, es decir, que la asimetría lumínica manifiesta un mensaje latente en el discurso poético demostrando las bondades de las clases dominantes e intentando generar desde lo simbólico un equilibrio social en el imaginario colectivo. De esta manera, las representaciones pictóricas activan y "justifican" mediante la metáfora visual una vida donde todo encaja y en la cual todo está estrictamente organizado según las convicciones e intenciones de quienes ejercen el poder. En parte, en las obras detalladas esta idealización se manifiesta a partir de una representación quimérica y perfeccionista de la sociedad, que "vuelve a presentar" mediante estos trabajos artísticos otra imagen de la esclavitud. Severo Sarduy se refiere a la concordancia entre el mundo real y el pictórico de una manera muy sugerente:

(...) no se trata de convocar la realidad en el cuadro para, sometiéndola a una iluminación contrastada, brutal, extraer de ella, de su configuración simbólica o de sus referentes mitológicos o bíblicos, una lección, ni tampoco revelar, por medio de la sobre-exposición, el agrandamiento arbitrario o la hipertrofia de un detalle, una verdad moral opuesta a la simulación que el cuadro configura, sino de realizar el cuadro a tal punto que éste se presente, se acredite y justifique como un nuevo fragmento, una nueva porción de la realidad objetiva afirmando así (...) que la supuesta realidad no vale ni más ni menos, que no hay jerarquías, en lo verosímil ni en lo ideológico cuando la ilusión está programada, configurada con el mismo empecinamiento y la misma minuciosidad que la realidad que, en ese grado de reflejo milimétrico, excesivo, ya no la precede. ${ }^{22}$

Esta mímesis simbólica también la observamos en la segunda metáfora visual que está relacionada con el espacio asignado a cada uno de los personajes de las representaciones artísticas objeto de esta reflexión, pero en este caso, la jerarquía no se genera a raíz de la luz sino de las propias fronteras del cuadro, que se reservan para las personas de baja condición social y por tanto, subordinadas a las figuras principales. Esta localización bordeando los límites físicos del bastidor encierra connotaciones simbólicas importantes, pero irá paulatinamente diluyéndose a medida que el su- 
jeto en cuestión vaya experimentando un cambio de estatus. En este punto, por supuesto, resulta esencial citar el estudio de Luis Méndez Rodríguez, quien aplica la idea de borde o margen para referirse al espacio que ocupaban en algunos casos los criados, las criadas, los esclavos y las esclavas en la pintura del siglo de oro, al respecto afirma: "(...) los negros fueron desplazados a los márgenes del lienzo en la pintura europea, teniendo un papel secundario y anecdótico en esta" ${ }^{23}$ Este lugar simbólico se hallaba afín a las circunstancias sociales de aquellos más desfavorecidos, pues como argumenta este autor las clases más bajas y humildes habitaban en la periferia:

Esta situación se agravó en las primeras décadas del siglo XVI, por ordenanzas del Consejo de la ciudad, como la de 1522, que obligó a fijar sus domicilios fuera de las murallas (...) considerando por tanto a los esclavos negros que no convivían todo el tiempo con sus amos y, sobre todo, a los libertos como socialmente peligrosos. ${ }^{24}$

No obstante, el posicionamiento liminal en las obras pictóricas formaba parte de un recurso empleado por el artista para expresar el descentramiento simbólico de criados y criadas con respecto a su señor o señora, pero no siempre esta metáfora visual viene a significar su situación de esclavitud. ${ }^{25}$

De la meticulosa catalogación que llevó a cabo Luis Méndez Rodríguez a lo largo de sus investigaciones podemos extraer que en la producciones artísticas la imagen de los esclavos, especialmente de las mujeres esclavizadas, se vinculó con las tareas domésticas, una actividad común a todas las criadas representadas en los bodegones del siglo XVII. En parte, como bien expone este autor, este condicionamiento se debía al hecho de que muchos artistas compraron a esclavas para realizar estas funciones o adquirían esclavos varones que se dedicaban a limpiar los talleres o a tareas específicamente artísticas y no cualificadas como moler los pigmentos o lavar pinceles. Luis Méndez Rodríguez indica que esta situación se traduciría en la primera "cadena de montaje" de la obra de arte y a la vez en el primer eslabón hacia la especialización de los esclavos en las diferentes disciplinas artísticas, que culminaría con la liberación y profesionalización. ${ }^{26}$

23 MÉNDEZ RODRÍGUEZ, Luis (201 1), Esclavos en la pintura sevillana de los siglos de oro, Universidad de Sevilla, Sevilla, p. 158.

24 MÉNDEZ RODRÍGUEZ, Esclavos en la pintura sevillana, p.37.

25 LOWE, "The lives of Africans slaves", p. 19.

26 MÉNDEZ RODRÍGUEZ, Esclavos en la pintura sevillana, p.68. 
En respuesta a esta tendencia, en la época barroca las representaciones artísticas vinculadas a la esclavitud manifiestan un giro conceptual importante y se perfilan como expresión de la tercera metáfora visual, que expone otra forma de distribución de los elementos visuales dentro de la estructura compositiva. Este reordenamiento da lugar a nuevos parámetros pictóricos y sociales y, al mismo tiempo, saca a la luz un mundo imaginario protagonizado por las esclavas y los esclavos, quienes progresivamente dejan los márgenes del cuadro al desplazarse hacia el espacio central de la composición. Este desplazamiento adquiere un relevante alcance simbólico que más tarde se proyectará en la esfera social como parte del proceso de liberación de varios esclavos y esclavas, al respecto podemos decir que en el espacio pictórico la mirada de estas personas se evidencia mucho más reflexiva y, por tanto, da cuenta de esta inminente transformación.

A partir de aquí, los esquemas binarios: blanco (amo, ama) / negro (esclavo, esclava) y luminosidad (rol protagónico) / oscuridad (rol secundario) caen por su propio peso y las figuras a la "sombra" van ocupando de manera gradual el espacio lumínico, lo cual les permite "dejarse ver" dentro de este nuevo status simbólico. Esta traslación en el mundo del imaginario se posiciona casi inmediatamente en el ámbito real y concreto de una sociedad que ya venía presintiendo ese cambio. Una metamorfosis social de diferenciación que Joaneath Spicer deja bien claro cuando se refiere al hecho predominante de "ser 'no blanco' más que negro per se". ${ }^{27}$ En un cierto sentido, las imágenes sobre la esclavitud están estrechamente ligadas a las representaciones raciales, como bien afirma Alessandra Raengo, cumplen una función ontológica, ser precisas como el reflejo de un espejo y confiables como una sombra, sin embargo, esta confianza se ve socavada cuando la imagen especular representa el encuentro del sujeto blanco y occidental con el Otro, algo sesgado y opaco que se debe rechazar. ${ }^{28}$ Cabe puntualizar, que mientras el Otro permanecía a la sombra como metáfora visual de subordinación y esclavitud, quien ejercía el poder tenía plena certeza de tener ambos mundos -real e imaginario- bajo control, no obstante, el avance simbólico de esclavos, esclavas, criados o criadas hacia el centro de la escena pictórica manifiesta en todas las esferas una inquietante desestabilización, paradójicamente expresada a través de la mirada del propio artista.

Un ejemplo de esta evolución podemos encontrarlo en la criada retratada por Velázquez, a este respecto Luis Méndez Rodríguez comenta que

27 SPICER, "European perceptions of blackness", p.40.

28 RAENGO, Alessandra (2013), On the Sleeve of the Visual: Race as Face Value, Dartmouth College Press, New Hampshire, p. 132. 
se trataba de una temática poco común en la pintura hispalense. ${ }^{29} \mathrm{Se}$ le atribuyen a Velázquez dos versiones de esta obra, por un lado, Criada de cocina con la cena de Emaús (1617-1618), ${ }^{30}$ en esta pintura que se encuentra en la Galería Nacional de Irlanda en Dublín se aprecia en el fondo del cuadro la escena de Cristo en Emaús, pero del relato bíblico tan sólo aparece un fragmento, el cual fue descubierto tras una restauración en 1933 y en su momento hubo un intenso debate sobre la autoría del artista en este detalle. ${ }^{31}$ Por otro lado, la obra Escena de cocina (1618-1620), ${ }^{32}$ que forma parte de la colección del Instituto de Arte de Chicago, representa exclusivamente a la mulata en la cocina sin la escena religiosa.

La inclusión de la parte bíblica en esta obra de Velázquez se interpretó como un "bodegón a lo divino", 33 además, la presencia del fragmento de la cena de Emaús se ha asociado al cuadro Los discípulos de Emaús o Cena de Emaús pintado por Caravaggio en 1602 (del cual también existe una segunda versión de 1606) y aparte de que ambas pinturas comparten el mismo pasaje de la Biblia, también aparecen sirvientes representados en ellas; equivalencia que puede apoyarse en el hecho de que la primera época pictórica de Velázquez tuvo influencias del artista italiano. En la obra de Caravaggio podemos observar que el criado mantiene una actitud impasible ante la presencia de Cristo, al contrario, en el cuadro de Velázquez, la inclinación leve de la cabeza de la criada podría manifestar humildad y devoción, igualmente, cabe destacar que Velázquez ubica a la criada en el mismo lugar central asignado a Cristo por Caravaggio, lo cual le proporciona a la sirvienta un gran protagonismo y relega la escena bíblica a un segundo plano dentro del esquema compositivo. Además, el rol protagónico de la criada se acentúa debido al mayor contraste lumínico de la representación que destaca su rostro y al detalle de los utensilios mediante una gran riqueza de matices cromáticos que le otorgan a las tareas domésticas un halo mágico y místico a la vez.

29 MÉNDEZ RODRÍGUEZ, Esclavos en la pintura sevillana, p. 75.

30 En exposiciones monográficas como Velázquez a Capodimonte realizada en el Museo di Capodimonte de Nápoles en el año 2005, este cuadro se presentó bajo el título Cena de Emaús obviando la primera parte referida a la criada.

31 LÓPEZ-REY, José (1996). Velázquez. Catalogue raisonné, vol. II, Colonia, Taschen Wildenstein Institute, p.42.

32 En la colección del Instituto de Arte de Chicago figura con el título Escena de cocina sin hacer mención a La mulata, título con el que se suele conocer comúnmente esta obra, aunque otras veces se utilizan los dos conjuntamente.

33 GÁlLEGO, Julián (1988), Diego Velázquez, Anthropos, Barcelona, p. 42. 
Por otro lado, a este cambio simbólico en las composiciones pictóricas debemos sumar un detalle importante en relación a la mirada de las personas de origen africano retratadas con gran virtuosismo a finales del siglo XVI durante el Renacimiento tardío, un posicionamiento frontal de la mirada que ponía de manifiesto metafóricamente los cambios sociales que se avecinaban. Tal es el caso de la obra Retrato de una mujer esclava africana (fragmento de un cuadro de mayor tamaño que incluía a su señora), atribuido a Annibale Carraci hacia el año 1580 y que perteneció a la Colección de Felipe V. Asimismo, este cuadro formó parte de la exposición Revealing the african presence in renaissance europe presentada en el Walters Art Museum (octubre 2012 - enero 2013) y en Princenton University Art Museum (febrero - junio 2013). Según los comisarios resultaba esencial el reconocimiento de la existencia de los esclavos y las esclavas en la pintura renacentista, de alguna manera, a través de esta exhibición se les daba visibilidad como una forma de restituirles su identidad. ${ }^{34}$ Desde la intrínseca antropología de la imagen se puede discernir cómo en el cuadro mencionado la protagonista mira directamente hacia el exterior de la representación, una acción que atrae y "atrapa" al público hacia el interior de la composición. Esta inversión del juego de miradas expresa una gran originalidad y un avance simbólico importante con respecto a los retratos reseñados, ya que en este trabajo en particular la esclava ejerce un rol activo al proyectarse fuera del lienzo y mediante esta actitud, simbólicamente expulsarse de ese mundo imaginario que la confina a la esclavitud.

En consecuencia, tanto la reubicación espacial en el esquema compositivo como la inversión del acto de mirar de las personas esclavizadas van a anticipar desde el ámbito simbólico la transformación social y artística protagonizada por esclavos o esclavas a partir del siglo XVII.

Esta anticipación simbólica da pie a la cuarta metáfora visual, que se enmarca en el cambio significativo llevado a cabo durante la primera mitad del siglo XVII por algunos esclavos quienes tras convertirse en libertos al obtener la liberación por parte de sus amos se dedican al trabajo artístico y a partir de aquí asumen el control de su vida y el de la representación pictórica. El caso más famoso fue el de Juan de Pareja, esclavo de Velázquez, quien fuera retratado por su amo en 1650 durante una estancia del artista en Roma y que ese mismo año recibe la carta de libertad..$^{35}$ El retrato

34 GARY, Vikan, "Director's foreword", en SPICER, Revealing the african presence, p. 7.

35 Sobre diferentes aspectos de la vida y obra de Velázquez consultar: BROWN, Jonathan (2008), Escritos completos sobre Velázquez, Centro de Estudios Europa Hispánica, Madrid. Desde una narrativa histórica resulta muy interesante VILLAVERDE, Fernando (2014), El esclavo de Velázquez, Suma, Barcelona. 
de Juan de Pareja, que actualmente se conserva en el Museo Metropolitano de Nueva York, fue realizado cuando aún él era esclavo, por ello, su figura todavía mantiene una cierta similitud cromática con el fondo del cuadro y, al igual que sucede en otras obras, este recurso le impide "despegarse" de la representación en un doble sentido: simbólico y social. En otras palabras, una vez más la innata antropología de la imagen manifiesta que el esclavo todavía preserva el rol de dependencia social hacia su amo y sigue "fijado" al mundo del imaginario hasta que se haga efectiva su liberación en 1654. Pese a ello, la imagen es realmente impactante, el esclavo luciendo un elegante vestuario adquiere una postura levemente inclinada, pero que denota cierta seguridad; con su cabeza en alto -al contrario que la criada retratada por Velázquez 30 años antes- y su mirada un tanto altiva transforma literalmente la semiótica de la imagen. A partir de esta nueva perspectiva, el simple acto, pero al mismo tiempo trascendente, de elevar la cabeza y mirar de frente, presagia el surgimiento de un nuevo ser que se está gestando en su interior, la creación de otra identidad que dejará atrás al esclavo para dar paso a Juan de Pareja, el artista.

Resulta paradójico que poco más de una década después, en 1661, Juan de Pareja realizaría un remake de ese retrato en su obra Conversión de San Mateo, la cual se puede contemplar en la actualidad en el Museo del Prado. Sobre este autorretrato Luis Méndez Rodríguez señala: "(...) se ha difuminado su fisonomía intencionadamente para ofrecer un aspecto diríamos más occidental. En su recién adquirido honor social, se libera de su condición de esclavo y de sus rasgos morfológicos de mulato", ${ }^{36}$ e incluso podemos intuir un parecido físico con el propio Velázquez.

La quinta y última metáfora visual que desarrollaremos está íntimamente asociada al retrato de Juan de Pareja realizado por Velázquez y su inserción en el ámbito artístico actual, esta extrapolación a la contemporaneidad nos permite abordar las reflexiones finales de un modo circular $y$, en cierto modo, concebir las distintas metáforas como puntos hacia una meta común al ver cómo artistas contemporáneos reciben el testigo de una realidad tan dramática como la esclavitud y reabren el debate mediante un discurso poético, crítico y reflexivo.

El artista senegalés Omar Victor Diop ejecuta en palabras de David Le Bretón una "citación cultural", ${ }^{37}$ mediante una personal apropiación simbólica

36 MÉNDEZ RODRÍGUEZ, Esclavos en la pintura sevillana, p. 147.

37 LE BRETON, David (2002), Signes d'identité. Tatouages, piercings et autres marques corporelles, Métailié, París, p. 161. 
recrea autorretratos de hombres ilustres de origen africano, que en su mayoría fueron esclavos o hijos de padres esclavos o libertos y que formaron parte de la historia europea entre los siglos XV y XIX, según la opinión del propio artista se trata de un período de intensa interacción entre África y el resto del mundo. ${ }^{38} \mathrm{~A}$ través de la fotografía propone su particular versión en un intento por reivindicar la dignidad de cada uno de los personajes retratados, una serie fotográfica que integra el proyecto expositivo Diáspora, presentado en el Gran Palais de París en el año 2014.

Este proyecto surge a raíz de una residencia artística de cuatro meses en la ciudad de Málaga, donde el artista inició una investigación acerca del sentimiento de ser "otro", de ser extranjero, centrando toda su atención en "(...) la dualidad de vivir una vida de gloria y reconocimiento frente a los desafíos de ser otro", ${ }^{39}$ una paradoja que él observa entre los futbolistas africanos que juegan en equipos europeos y los personajes de retratos antiguos que él decide imitar a través de la fotografía. ${ }^{40}$ Esta alusión al fútbol en las imágenes se produce mediante la incorporación de diferentes objetos del ámbito futbolístico como trofeos, balones o botines y también por la representación de figuras claves de este deporte como los árbitros.

Entre las obras pictóricas originales seleccionadas por Omar Victor Diop se encuentra el retrato de Juan de Pareja realizado por Velázquez, pero en esta versión contemporánea, el artista no sólo asume la personalidad del esclavo sino que la representación expresa algunas modificaciones que transforman el sentido original.

En esta obra el artista nos mira de una forma más frontal y desafiante, no disimula el color de su piel como lo hizo Juan de Pareja al retratarse en la Conversión de San Mateo y, además, en esta imagen contemporánea el retratado se separa completamente del fondo de la composición, un recurso que desde un punto de vista simbólico "trae al frente" al esclavo, de tal modo que en la fotografía el color de la piel resalta de manera contundente y el personaje ya no se difumina en la sombra. En este sentido, de la propia antropología de la imagen podemos percibir que el contraste de luz y color le confiere al sujeto relieve y volumen, con la clara intención de avanzar hacia el exterior de la representación y con el fin de plantar cara a la sociedad, un acto que sin lugar a dudas dignifica desde la metáfora al olvidado Juan de Pareja.

38 WILSON, Raquel, "Diáspora. Self-portrait, 2014", s. p.

[Recuperado de: https://www.omarviktor.com/project-diaspora]

39 WILSON, "Diáspora", s. p.

40 WILSON, "Diáspora", s. p. 


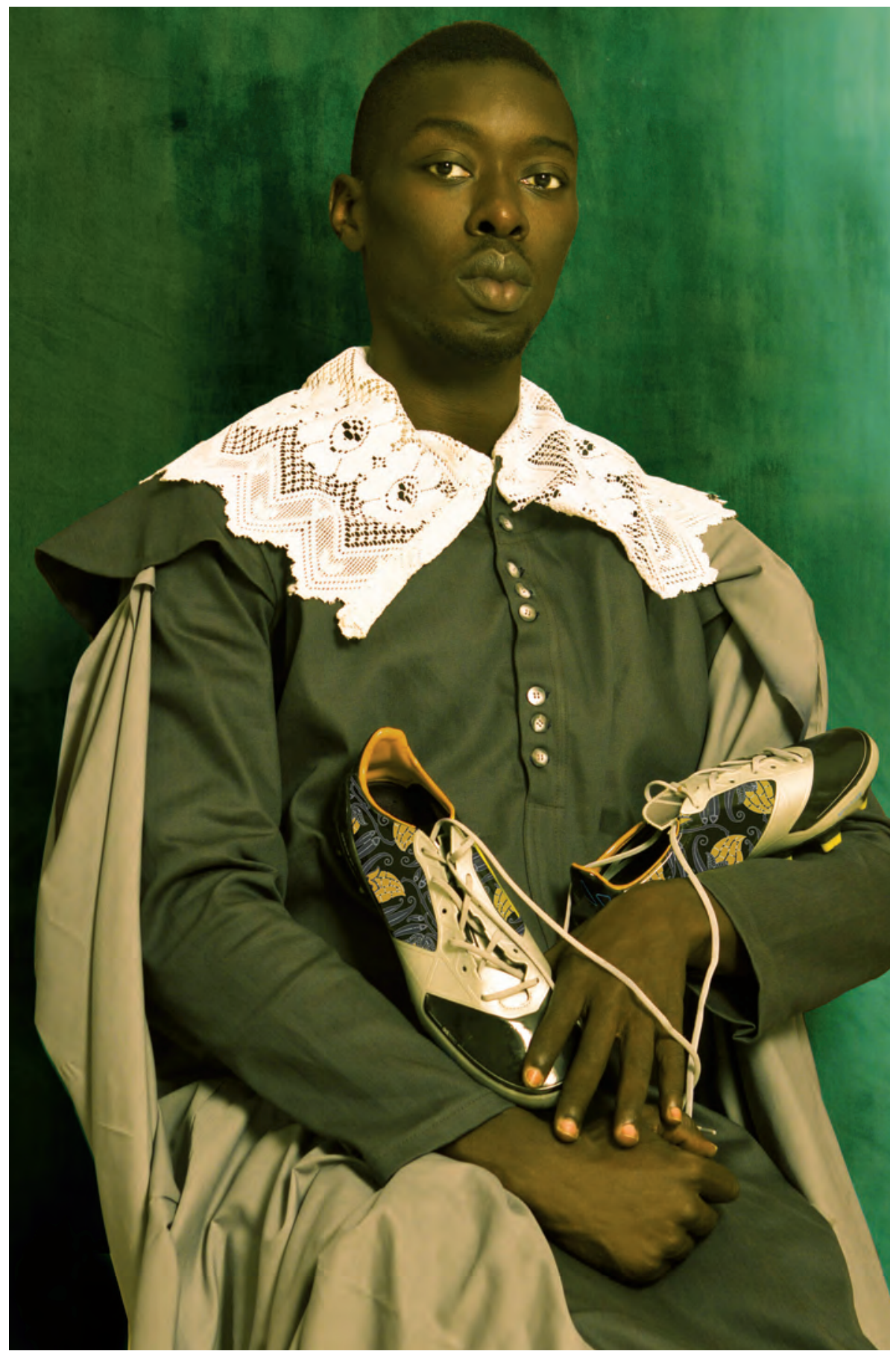

Fig. 1. Omar Victor Diop. Juan de Pareja, 2014. Diaspora series. (C) Omar Victor Diop. Courtesy Galerie MAGNIN-A, Paris. 
Omar Victor Diop caracterizado en la figura del esclavo sostiene unos botines de fútbol, que le otorgan a la imagen un aire de extrañeza, incluso rozando el absurdo si tomamos como referencia la pintura original; sin embargo, como ya hemos señalado, con esta inclusión iconográfica el artista senegalés pretende actualizar y enunciar a través de este tipo de objetos la realidad que comparten tanto los hombres ilustres retratados como los futbolistas africanos actuales, y que pese a los siglos que los separan, ambos colectivos han sido víctimas o aún siguen sufriendo las mismas circunstancias: fama y otredad.

Mediante esta serie fotográfica Omar Victor Diop pretende cuestionar la propia construcción de la historia y, simultáneamente, dar respuesta a sus propios interrogantes acerca de su identidad como artista y como persona. ${ }^{41}$ Esta última metáfora visual planteada en el contexto del mundo artístico contemporáneo establece lazos con el pasado y evidentemente desvela de forma clara el objetivo principal de este artículo, ya que revela que tanto los elementos iconográficos como los mensajes latentes que subyacen en el seno de las composiciones artísticas expresan aspectos específicos del entramado social. Por otra parte, el proyecto Diáspora presentado por Omar Victor Diop completa el análisis al expresar los vaivenes históricos y poner a debate las vicisitudes del mundo "real" e "imaginario" entre África y Europa. En definitiva, hemos llegado a un punto del recorrido donde todo parece confluir en otra visión de la sociedad y de la historia, donde finalmente y sin reparos podemos afirmar: "Black is beautiful". ${ }^{42}$

41 WILSON, "Diáspora", s. p.

42 "Black is beautiful" fue un movimiento cultural norteamericano surgido en 1960 que luchaba por los derechos de las personas de origen africano en contra de argumentos raciales y estereotipos de belleza basados en la estética blanca y occidental. También nuestra cita se refiere a la exposición Black is beautiful: from Rubens to Dumas, que se llevó a cabo del 26 de julio al 26 de octubre de 2008 en De Nieuwe Kerk, Amsterdam. Esta exhibición proponía un extenso recorrido sobre la representación de personas de piel negra en la pintura de los países bajos desde el siglo XIV hasta la actualidad, cuyo título cita -a modo de homenaje- aquellas reivindicaciones iniciadas hace casi 60 años. 



\title{
LA LEGENDARIA VIDA DEL RENEGADO CALABRÉS UCHALI QUE DE ESCLAVO LLEGA A SER REY EN LA HISTORIA Y EN LA LITERATURA
}

\section{THE LEGENDARY LIFE OF THE CALABRIAN RENEGADE UCHALÍ WHO BEING SLAVE HE BECOMES KING IN HISTORY AND IN LITERATURE}

\author{
María Teresa Morabito \\ Università degli Studi di Messina \\ María LuISA TOBar \\ Università degli Studi di Messina
}

\begin{abstract}
RESUMEN
Este trabajo se centra en la legendaria figura del renegado calabrés Dionisio Galeno más conocido como Uchalí que por su valor y sus dotes de estratega en las guerras cristiano-turcas por el dominio del Mediterráneo, especialmente en la batalla de Lepanto, de esclavo llegó a ser Rey de Argel y Capitán General del Mar. Primero hemos examinado documentos y testimonios de coevos y también las primeras biografías para presentar su figura histórica y, segundo, hemos analizado como cronistas y poetas del siglo XVl y dramaturgos de principios del XVII recogen y transmiten la extraordinaria imagen de este esclavo y rey.
\end{abstract}

Palabras clave: Uchalí, esclavitud otomana, crónicas siglo XVI, poemas siglo XVI, teatro siglo XVII.

\begin{abstract}
This work is based on the legendary figure of the Calabrian renegade Dionysus Galen, better known as Uchali, that became king for his value and his skills as a strategist in the Turkish Christian wars for the domination of the Mediterranean, especially in the battle of Lepanthus, that he began as a slave to become then King of Algiers and Captain General of the Sea. At first we examined the documents and the coeval witnesses and also the first biographies to present the historical figure. Secondly, we have analyzed how 16th century journalists and poets and playwrights of the beginning of the 17th century collect and transmit the extraordinary image of this slave and king.
\end{abstract}

Keywords: Uchali, Ottoman slavery, 16 th c. Chronicles, 16th c.Poems, 17th c. Theatre. 


\section{RESUM}

\section{LA LLEGENDÀRIA VIDA DEL RENEGAT CALABRÈS UCHALÍ QUE D'ES- CLAU VA ARRIBAR A SER REI A LA HISTÒRIA I A LA LITERATURA}

Aquest treball es centra en la llegendària figura del renegat calabrès Dionisio Galeno, més conegut com a Uchalí, que pel seu valor i els seus dots d'estrateg en les guerres cristià-turques pel domini del Mediterrani, especialment en la batalla de Lepant, d'esclau va arribar a ser Rei d'Alger i Capità General del Mar. En primer lloc hem examinat els documents i els testimonis de coetanis i també les primeres biografies per a presentar la seua figura històrica i, en segon lloc, hem analitzat com cronistes i poetes del segle XVI i dramaturgs de principis del XVII recolliren i transmeteren l'extraordinària imatge d'aquest esclau i rei.

Paraules clau: Uchalí, esclavitud otomana, cròniques segle XVI, poemes segle XVI, teatre segle XVI. 
En este trabajo no pretendemos hacer una biografía sistemática de la vida de un personaje fascinante llamado Giovan Dionigi (Dionisio) Galeno que, al renegar de su religión toma el nombre de Uluch Alí, Uchalí, como le llama Cervantes en el Quijote, sino más bien trazar un esbozo de su recorrido vital deteniéndonos sobre todo en los aspectos más inherentes al tema general de esta publicación: la esclavitud. Ciertamente estamos ante un hombre de frontera con sus luces y sus sombras, amado y estimado por muchos que lo consideraban justo, generoso y conciliador; temido e incluso odiado por los que lo juzgaban despreciable, despótico y cruel, aunque todos reconocían su valor, su capacidad de mando y sus dotes de estratega en la guerra de corso, como bien demostró en los conflictos armados entre turcos y cristianos por el dominio del Mediterráneo, sobre todo en la batalla de Lepanto, donde fue el único de los generales turcos que consiguió no ser derrotado e incluso hacerse con algunas galeras cristianas.

No es extraño, pues, que ya en vida surgieran leyendas en torno a su persona y que los cronistas, poetas y dramaturgos se hayan hecho eco de sus empresas. Precisamente en la segunda parte de nuestro trabajo hemos analizado la figura de Uchalí en algunos textos literarios en los que el renegado calabrés ocupa un lugar preeminente entre los turcos: dos crónicas que se publican un año después de la batalla de Lepanto; tres poemas épicos escritos también a raíz de la contienda naval; y para terminar, nos hemos detenido en la dramatización que de este personaje hacen dos autores de principios del siglo XVII. 


\section{LA FIGURA HISTÓRICA DE UCHALI}

\section{El calabrés Dionisio Galeno se convierte en el renegado Aluch Ali}

La primera biografía de este legendario personaje se encuentra en el capítulo XVIII de Epítome de los Reyes de Argel, contenido en la Topografía e Historia general de Argel,' que fue publicada en 1612 por el abad de Frómista fray Diego de Haedo, el cual en la dedicatoria a su tío Don Diego de Haedo, arzobispo de Palermo, Presidente y Capitán General del Reino de Sicilia, firmada en Frómista el 25 de diciembre de 1605, dice que una de las razones por las que le dedica el libro es por haberlo compuesto él con las informaciones de cristianos cautivos "especialmente de los que se contienen en los Diálogos, que estuvieron muchos años en Argel, y habérmelos entregado, estando yo en Palermo en su servicio, aunque en borrón: de manera que sin el trabajo y diligencia que en ellos he puesto, dándoles la última forma y esencia, no se podían imprimir, ni sacar a luz". De estas palabras resulta evidente que fray Diego de Haedo es solo la persona que se encarga de recoger, ordenar y publicar los papeles que recibe de su tío el arzobispo de Palermo, no el autor de esos papeles.

Sin embargo, George Camamis (1877: 59 y ss, y 147) va más allá pues cree que, aunque Haedo haya publicado la obra con su nombre, el verdadero autor fue probablemente el benedictino Antonio de Sosa que fue compañero de Cervantes durante su cautiverio en Argel y que debió de escribir la obra entre los años 1577 y 1581 . Emilio Sola ${ }^{2}$ ratifica esta au-

1 La Topografía contiene cinco libros: Topografía de Argel, Epítome de los reyes de Argel más tres Diálogos: De la cautividad, De los mártires y De los Morabutos. El capítulo XVIII del Epítome está enteramente dedicado a la biografía de Ochalí, como se le llama en está obra (ff. 47r-95v). Pero también viene citado en numerosas ocasiones a lo largo de toda la obra.

2 Emilio Sola dice que después del espléndido estudio de Camamis "parece definitivamente esclarecida la autoría de la Topografía e Historia general de Argel, título genérico que engloba la «Topografía» propiamente dicha, el «Epítome de los reyes de Argel» y los tres «Diálogos», el De la cautividad, el De los mártires y el De los morabutos. Escrito en primera persona y con abundantes referencias autobiográficas que cuadran exactamente con el periodo de cautiverio de Antonio de Sosa en Argel -desde principios de 1577, en que llega a la ciudad con otras doscientas noventa personas cautivas de la galera «San Pablo», hasta después de mediado el año 1581-, ni el abad de Frómista Diego de Haedo ni su tío homónimo arzobispo de Palermo y gobernador de Sicilia, muerto en 1608, que nunca estuvieron en aquella ciudad berberisca, pudieron ser los autores de tan exhaustivo y abrumador texto. Diego de Haedo, por lo tanto, sería sólo el editor de aquellos manuscritos que trajo consigo a España en 1599 después de un viaje a Palermo, sin duda cedidos a su tío por el propio Antonio de Sosa; en 1604 había gestionado ya licencia para su publicación y, después de la muerte de su tío y del mismo Sosa, en 1612 los publica en Valladolid" (1991: 409). También se ha apuntado la posible autoría de Cervantes. EISENBERG, 1996: 32-33. Sin entrar en mérito al problema, pero reconociendo 
toría argumentando que un relato tan exhaustivo y abrumador solo podía proporcionarlo un testigo de los acontecimientos relatados. De hecho, las noticias referentes a Uchalí, sobre todo las de la época en la que Sosa estuvo cautivo en Argel (1577-1581), son tan puntuales que da la impresión de que están redactadas partiendo de apuntes tomados en el momento y en el lugar de los hechos, por lo que constituyen la biografía más completa y documentada de la vida de Uchalí.

El capítulo XVIII del Epítome, titulado Ochalí Bajá décimo nono [rey], empieza poniendo a Uchalí como ejemplo de los caprichos de la mudable fortuna, e inmediatamente resume en pocas líneas sus orígenes y primeros años de galeoto:

"Uno de los hombres en los cuales, en nuestros tiempos, la Fortuna quiso burlarse, como dice el Poeta, mostrando lo que pueden sus antojos, fue el Aluch Alí, a que corruptamente llamamos Ochali, porque Aluch, en morisco, significa lo mismo que nuevo moro o nuevo convertido, o renegado, $y$, ansí, no es nombre, mas sobrenombre, como el de renegado, y el nombre propio es Alí, y, ansí, Aluch Alí quiere tanto decir como el Renegado Alí. Hoy día no le llaman sino Alí Bajá, dejando el Aluch con que antes era llamado, pero, pues habemos de hablar con el vulgo como dijo Aristóteles llamarle, hemos Ochalí. Este era natural del Reino de Nápoles, de la provincia de Calabria, de un lugar pequeño, que está cerca del cabo de las Colonas, y que se dice Licasteli, de padres muy pobres y miserables. De su mocedad, se dio al oficio de pescar y de barquero: hasta que fue tomado y captivado de un corsario principal que se decía Alí Amet renegado griego que fue muchos años capitán de Argel en la mar. Y como era ya mancebo y recio, y en la mar criado y curtido, el Alí Amet le puso luego al remo de su galeota, en que bogó muchos años, y como era tiñoso, con la cabeza toda calva, recibía mil afrentas de los otros cristianos, que no querían a veces comer con él ni bogar en su bancada, y de todos era llamado Fartax, que en turquesco quiere lo mismo decir que tiñoso. Al último, dándole un día un levente (esto es, un soldado corsario) un bofetón, se hizo turco y renegado con intención de vengarse de él, pues siendo cristiano no lo podía hacer. Hecho turco su patrón sabiendo cómo era gentil marinero, le hizo a

los argumentos a favor de la autoría de Sosa, en adelante, citaremos la obra publicada por Haedo sin la indicación del autor, sino con el título de cada uno de los libros que contiene el texto citado. 
poco tiempo su cómitre, en el cual oficio ganó en pocos años buenos reales, con los cuales, y en compañía de otros tales armó en Argel una fragata o bergantín, y con éste robando por esos mares, vino a hacer una galeota y a ser uno de los mejores Araeces de Argel" (1612: ff. 77r-77v).

Además de la desaparecida Vita di Ulucciali, ${ }^{3}$ que en opinión del antropólogo Vito Teti es "opera di fondamentale importanza ancora in larga parte inedita" (2008: 144), Gian Giacomo Martini se ocupa de Uchalí también en Consiliorum (1635), ${ }^{4}$ obra en la que no solo hace referencia a su inédita obra Vita di Ulucciali sino que también habla del renegado calabrés en varias ocasiones. Por lo que se refiere a su nacimiento dice: "Giovanni Dioniso Galeno, chiamato tra i turchi Uluccialì calabrese di nascita, la sua patria era Le Castella vicino Crotone, figlio illegittimo di Birno Galeno e di Pippa De Cicco". ${ }^{5} \mathrm{Ni}$ en el Epítome ni en Martini se indica la fecha de nacimiento de Gian Dionigio Galeno, sobre la que se han hecho varias hipótesis. Gustavo Valente la coloca en torno a 1520 (1973: 134), propuesta poco probable pues contrasta con algunas relaciones de la época, como la del bailío recién llegado de Constantinopla, Gian Francesco Morosini, que en 1585 dice que Uchalí, entonces capitán del mar otomano, "di nazione calabrese nato vilissimamente in un luogo detto Li Castelli non sa né leggere né scrivere", y añade que en 1585 tenía casi 80 años y era tan "prospero e gagliardo" que suscitaba maravilla; un año antes Giacomo Soranzo, otro diplomático véneto, había dicho que Uchalí estaba cerca de los ochenta; y el bailío veneciano Lorenzo Bernardo, el mismo día de su muerte $(27$ de junio de 1587), en la semblanza que de Uchalí traza para el dux de Venecia Pasquale Cicogna, dice que tenía más de 80 años. ${ }^{6}$ Sola, después de un atento examen de los documentos, y basándose precisamente en que

3 Afortunadamente conocemos el texto de Martini gracias a la obra de Domenico Martire que según sus propias palabras toma totalmente de Martini: "Tutto il narrato d'Huccialì si è da me raccolto dalla vita manoscritta dell'abate Giangiacopo Martino nostro calabrese di S. Nicola di Valle Longa che imperfetta lasciò, e precoce dopo finita, darla alla luce, conforme egli stesso lasciò scritto nel suo volume de' Consigli impressi al consiglio $2^{\circ} \mathrm{n} .{ }^{\circ} 56^{\prime \prime}$ (Teti, 2008: 144).

4 Hay una edición moderna hecha por Vito Teti, (Roma, Donzelli, 2003).

5 Citado por Teti el cual, además, sobre los numerosos nombres que recibe Uchalí, escribe: "Giovan Dionigi Galeno, Giandionigi Galeni, d'Alucciali, d'Huccialì, Uluccialì, Aluccialì, Luzzalì, Uccialì, Ucciallì, Uichialì, Occhialì, Vuccialì, Vluzzalì, Vluccialì, Uluosch-Alì, Ouloudi-Alì, Uluch-Alì, Uludas-Alì, Euldi-Alì, Ulugh Alì, Kiliç Alì Pasha: la mobilità del nome è davvero emblematica della colorata «immagine» di un personaggio (o di tanti personaggi) e di una storia (e di tante storie) che raccontano di ambiguità e di conflitti, delle complessità e delle dinamiche identitarie, individuali e collettive" (2009: 144). Pero no son estas las únicas variantes que presenta el nombre, en los textos que hemos consultado hay otras. 
el bailío veneciano lo hace octogenario en el momento de su muerte, en 1587, supone que nació "entre 1503 y 1507 o en torno a 1518 como límite, según la cronología que emana del contador Alonso Sánchez, la mejor aproximación al calabrés de los servicios de información hispanos" (2010: 26). Sin embargo, si tenemos en cuenta que en el Epítome se lee que "en el año 1580 era de edad de 72 años y no estaba del todo cano" (f. 80v), la fecha de su nacimiento habría que colocarla en torno a 1508. De todas formas, este dato parece contrastar con la escueta descripción que en el mismo Epítome se hace de Gian Dionisio en el momento de su captura: "y como era mancebo y recio, y en la mar criado y curtido, el Alí Amet le puso luego al remo donde bogó muchos años" (f. 77v).

Otro punto en el que coinciden los biógrafos es que Giovanni Dionisio Galeno o Galeni nació en Le Castella (Crotone), una pequeña localidad en la Calabria Ultra bañada por el mar Jónico y que sus padres eran humildes pescadores: hijo de padres "muy pobres y miserables" se lee en el Epítome, hijo ilegítimo de humildes pescadores dice Martini y Morosini informa que nació "vilissimamente", es decir, de humilde y baja condición social; el bailío veneciano Lorenzo Bernardo añade que es analfabeto. Por el contrario Martire, siguiendo a Martini, dice que Gian Dionisio era "dotato di buon ingegno e che frequentava la scuola, con «lodevole profitto" (f. 554r). A finales de agosto de 1536 Jairedin Barbarroja asalta y saquea las costas calabresas y después de tres días de asedio a Le Castalla, el 28 de agosto el joven Dionisio según algunas fuentes es capturado por el renegado griego Alí Amet; también son capturados su madre Pippa di Cicco y su hermano menor de siete años, mientras su padre Birno muere en la lucha. El contador Alonso Sánchez, a principios de 1569, cuando Uchalí acababa de ser nombrado bajá de Argel, narra así la captura del joven Dionisio:

"Aluchalí, que agora es rey de Argel, es natural de la tierra de Le Castella, de la provincia de Calabria Ultra; llamábase por nombre Dionisio Galea. El cual, teniendo de edad 18 años, fue tomado del armada de Barbarroja, ${ }^{7}$ con él su madre, nombrada Pippa del Chicco y su hermano. Su madre y hermano del Aluchalí fueron llevados a Constantinopla. Él fue llevado a Natolia, de un corsario nombrado

6 Arch. di Stato di Venezia (en adelante ASV), Senato, Dispacci Costantinopoli, filze 25, ff. 413 $421,27 / 6 / 1587$.

7 El informe se conserva en el Archivo General de Simancas, que en adelante citaremos como AGS, Sección de Estado, leg. 487, doc. 122. 
Juseli Maymet, con quien estuvo a la cadena por esclavo, como cristiano, dos o tres años. Al cabo de ellos se hizo turco". ${ }^{8}$

Según el informe de Sánchez su madre fue esclava en Constantinopla durante siete años y al ser liberada volvió a Calabria pero no a Le Castella, lugar que había sido abandonado por sus habitantes, sino a Cutro donde estuvo hasta su muerte. En cambio su hermano que tenía siete años "hiciéronle turco en Constantinopla, adonde está con su mujer e hijos". Sánchez da también noticias de otros parientes de Uchalí que vivían o en Santa Severina o en Isola di Capo Rizzuto, pues "tomada la dicha terra delle Castelle, y quemada y arruinada, la gente que no se tomó, y la que después se rescató, se fue a habitar a Cutro, en l'Isola, en Cotrón y en Santa Severina". ${ }^{\prime}$

Por lo que se refiere a su captura y conversión al islamismo el relato de Martire se aleja, en parte, del de otros biógrafos; el autor calabrés, después de relatar el asedio y saqueo de Barbarroja a Le Castella y la muerte de Birno, dice que "Giandionigi figlio fatto Schiavo" y llevado a Constantinopla fue malvendido por ser tiñoso: "sendo giovane mal disposto, tutto tignoso, e di mala vista, fù venduto per vil prezzo ad un Corsale nomato Giafer da cui venne posto alle catene e al remo in una delle tre galeotte" (f. $554 r$ ). Parece que el joven esclavo conquista la confianza y simpatía de su dueño y de su mujer Martama, tanto que estando ella enferma Giafer lo dejó al su cuidado mientras él estaba ausente, la cual "ben'osservate le maniere d'esso Giandionigi, risolse di dargli per moglie una sua figlia, conche avesse lasciato la fede Cristiana". Al volver Giafer, informado del buen comportamiento de Gian Dionisio, lo empezó a tratar todavía mejor que en pasado y esto le procuró la envidia de otros dos esclavos de la casa, uno siciliano y otro napolitano, que envidiosos de su estado lo

8 El documento relativo a Alonso Sánchez se encuentra en el AGS, Sección de Estado, leg. 487, doc. 122. Noticias sobre la incursión de Barbarroja a las costas calabresas se encuentran también en AGS Estado, Nápoles leg. 1113 , f. 116, de 26 y 29/11/1537 y leg. 1025, doc. 103, de 29/11/1536; en AGS Estado, Sicilia, leg. 117/118 de 8/11/1536; y en AGS Estado "Nuevas de Levante", leg. 1025, doc. 104 desde el /11/1536.

9 AGS, Sección de Estado, leg. 487, doc. 122. Le Castella es el extremo de la localidad de Isola de Capo Rizzuto que era el lugar más expuesto, por eso Andrea Carafa, lugarteniente general de Nápoles entre 1523 y 1526, ordenó la reconstrucción de la fortaleza del islote adaptándolo a las modernas exigencias defensivas, lo que no impidió que el lugar fuera devastado por Barbarroja. Con el abandono del lugar empezó su decadencia que ha durado hasta la segunda mitad del siglo XX, cuando, gracias al turismo, se ha ido transformando hasta convertirse en una de las localidades balnearias más atractivas de la costa calabresa bañada por el mar jónico. 
"maltrattarono con villanie, in tal guisa che un giorno innanzi al padrone e per alcune parole il Napoletano die' uno schiaffo a Giandionigi. Ma costui tutto che fosse convalescente, gli replicò con un pugno sì gagliardo che fello subitamente morire. Tosto carcerato Giandionigi, fù in pericolo di perder la vita, se in tal emergenza non si fosse servita Martama dell'occasione, con indurlo a rinegar la fede, acciò che siffattamente avesse preso per moglie Vracadurna sua figlia. Quindi sbattezzato fù chiamato Uluccialì, tanto nominato tra' Cristiani e Turchi nel secolo passato per le varie prodezze da lui fatte sebbene in danno del Cristianesimo che ne sofferse le molte perdite dagl'Istorici decantate, oltre all'altre da loro taciute e forse non sapute. Uluccialì, questo sarà in avvenire il nome di lui, stante che negò la fede avanzandosi all'arte marinaresca e militare, d'astutia e di prudenza, venne impiegato in varie cariche, in cui troppo portossi ben col suo valore. Avvegnache nel seguente anno Giafer mandò Alì suo figlio in corso, e con esso lui Uluccialì, e accompagnatosi con Dragut Generale dell'armi Ottomane, ne contrasse grande amicizia, e per le sue maniere s'acquistò gran nome e riputatione appo al medesimo, e vi è più appo Solimano Imperatore de' Turchi allora regnante" (f. 554r-v).

La vida de esclavo de Gian Dionisio, sean pocos -como dicen Martire y otros autores-, o muchos -según el testimonio de Cervantes ${ }^{10}$ y Sosa- los años que pasó como tantos otros galeotes "amarrado al duro banco / de una galera turquesca, / ambas manos en el remo" [...] quejándose "al ronco son / del remo y de la cadena" (por decirlo con palabras de Góngora), no tuvo que ser fácil. Pues en su caso, a las duras condiciones de vida a que estaban sometidos los esclavos puestos al remo, hay que añadir las derivadas de su poco agradable aspecto físico, consecuencia de la enfermedad de la tiña que dejaba señales visibles. Esto hacía más penosa y dura su condición, pues tenía que soportar ser estigmatizado incluso por sus compañeros que no querían remar en su mismo banco ni comer con él. Como se lee en el Epítome "de todos era llamado Fartax, que en turquesco quiere lo mismo decir que tiñoso" (77v) y seguramente fueron muchos los

10 El cautivo cervantino dice: "Y ese Tiñoso bogó el remo, siendo esclavo del gran señor, catorce años, y a más de los treinta y cuatro de su edad, renegó de despecho de que un turco, estando al remo, le dio un bofetón y por poderse vengar dejó su fe (Don Quijote, I, XL). 
insultos, humillaciones, ofensas, vejaciones que tuvo que soportar hasta que abofeteado por otro esclavo napolitano reacciona matándolo; y si hasta entonces se había mantenido fiel a su religión, para no ser condenado a muerte ahora se convierte al Islam como única posibilidad de salvar su vida. Su conversión no solo le va a permitir adoptar el traje turco y, por tanto, cubrirse la cabeza con el turbante ocultando así las señales de su estigma, sino que además gracias a ella va a dejar de ser galeote pero no esclavo y pasa a ser cómitre y, según la narración de Martire, también yerno de Giafer, por haber esposado su hija Vracadurna.

\section{La llegada a la cúspide del poder de Uchalí}

A partir de este episodio, ya con el nombre de Aluch Alí, ${ }^{11}$ la suerte del esclavo calabrés cambia; con el dinero ganado como cómitre se hace con un barco y entra en la guerra de corsa robando, saqueando y capturando personas por las costas del Mediterráneo. Su afortunada intervención en la batalla de Los Gelves es determinante en su vertiginoso ascenso hasta llegar a la cúspide del poder. En el Epítome se resume así su escalada social:

"Dende entonces [la conquista de Los Gelves] creció mucho la fama y reputación del Ochali, y, particularmente, el Piali le quedó muy aficionado. Después, en el año del Señor de 1565, cuando la guerra de Malta, el Ochali se halló en ella, en compañía de Dargut Raez el cual siendo muerto sobre Santelmo de un golpe que le dio en la cabeza una piedra que saltó de Santelmo, donde una bala había dado, el Piali Bajá, como general del Turco en la mar y de todos los lugares marítimos, por la afición que tenía al Ochali, le hizo Rey y gobernador de Tripol, en lugar del Dargut muerto, cuyo cuerpo mandó que llevase a enterrar. Partióse el Ochali con tres galeotas de Malta, y llegado a Tripol se apoderó de cuantos baxeles, municiones, ropa, dineros, esclavos y hacienda quedara del mismo Dargut. Gobernó a Tripol dos años y medio, en el cual tiempo se hizo muy rico, ansí con lo que quedara de Dargut como con el continuo corso y robar que hacía, saliendo de Trípol y robando por todas las marinas de Sicilia, Calabria y Nápoles. Y como él hacía tanto caso y fundamento de la amistad de Piali Bajá, enviábale siempre ricos presentes. El

11 Las fuentes turcas y cristianas que documentan ampliamente sus correrías por todo el Mediterráneo, han sido atentamente examinadas en trabajos recientes, sobre todo en las biografías de Antonio Sola y Vito Teti, a las cuales remitimos para un estudio más completo. Sin embargo, por estar estrechamente relacionados con el tema de la esclavitud, recordaremos brevemente algunos episodios que se refieren a su relación con los esclavos. 
Piali, para gratificar estas buenas obras, hizo tanto que acabó con el Turco, como estando descontento del Mahamet Bajá, por lo que usara con los moros de Constantina, le enviase en su lugar por Rey y Gobernador de Argel: llegó como dijimos, a Argel en principio del mes de marzo del año de 1568" (ff. 77v-78r).

Al final del capítulo dedicado a Uchalí, en el Epítome se lee que los turcos lo tenían en gran reputación y que gobernó en todos los asuntos que tenían que ver con el mar con más poder y autoridad que ningún otro bajá y, además, se explica su tenor de vida:

"Hizo una muy grande y muy sumptuosa casa, en que vivía, cinco millas de Constantinopla, en la ribera o marina del canal de mar que de Constantinopla y Gálata va para el mar Negro, y luego, a poco espacio, hizo también una mezquita que toca dentro de la mar, muy grande, muy rica y sumptuosa, y cabe ella una cuba o sepultura muy linda y muy galana, a la usanza turquesca, en que después de muerto le enterraron. No tenía hijo ni hija, pero tenía más de 500 renegados de su casa, a que sustentaba y llamaba hijos" (f. 80v).

El bailío veneciano Bernardo, en la semblanza que hace de él, dice que nada más morir Uchalí, el Gran Señor dio orden de sellar todos sus bienes e inventariar todos sus esclavos y patrimonio, ${ }^{12}$ y añade que, entre otras cosas, tenía dos bellísimos serrallos sobre el canal, más de dos mil esclavos de los cuales más de 550 maestranzas en el Arsenal. El veneciano pone de relieve que el rápido ascenso que Uchalí consiguió por su gran valor, fortaleza e ingenio maravilló a todos y que era amado y estimado por los grandes hombres de la "Puerta", que acudían a él para que arbitrara en sus cuestiones. También dice de él que era un hombre liberal y magnánimo, "un bravissimo huomo non solo nella professione del mare, ma anco prattico et intelligente nelle cose del mondo", aunque también era "huomo crudelissimo et talmente colerico" que no se le podía llevar la contraria. Pero una de sus características principales era su frenético activismo que le llevaba a estar siempre en movimiento sin tregua ni descanso; él mismo decía que su vida era un continuo "travaglio", (término que hay que entender en su significado polisémico de fatiga, padecimiento, tribulaciones). Cons-

12 Murió sin dejar hijos por lo que el heredero de su gran fortuna era el sultán, aunque con él vivían 500 renegados a los que trataba como si lo fueran. Un hijo suyo llamado Carabey murió en la batalla de Lepanto, según Fernando de Herrera, como luego veremos. 
ciente de su posición y de su propio valer quiere dejar perenne memoria de su persona y para ello hace construir una mezquita en Constantinopla donde dispone que debe ser enterrado. En esta mezquita, intitulada a Kiliç Ali Pasá, situada a orillas del Bósforo, también conocida como la mezquita de Uchalí, yacen los restos de aquel cautivo despreciado hasta por sus mismos compañeros de esclavitud al que llamaban despectivamente El Fartax (el tiñoso) y luego, al renegar de su religión, Uluch Alí, (en sus numerosas variantes), para llegar a su último apelativo Kilic (espada tajante), que todavía pervive en este monumento a la memoria de uno de los hombres más poderosos del imperio otomano.

Martire también subraya que con sus propias hazañas se ganó el favor incluso del sultán:

"Furono tali e tante le prodezze di Hucciali, che per poterlo rimaritare Selim Imperatore, il fec[e] suo Supremo Ammiraglio dell'armata, e tutto che fosse di sangue villano il volle per suo genero, dandogli per moglie una sua figlia: posegli anche in fronte le corone di tre primi Regni dell'Africa, cioè d'Algieri, Tripoli e Tunisi. Alle conquiste de' quali, fatte in altre tempi dall'armata Spagnola, servì in parte $O$ in tutto l'ingegno e maestria di lui" (f. 560v).

\section{La relación de Uchalí con los cautivos, esclavos y renegados. ${ }^{13}$}

Pero como todos los grandes hombres, Uchalí tiene sus luces y sombras; por lo que se refiere concretamente a su relación con los esclavos y los

13 Robert Davis (2004) calcula que más de un millón de europeos cristianos fueron capturados y esclavizados en el norte de África desde principios del siglo XVI hasta mediados del siglo XVIII por los comerciantes de esclavos de Túnez, Argel y Trípoli. Se trata de un fenómeno muy complejo, que como bien dice Nicolas Vatin (2012) presenta variables y múltiples facetas. A partir de los últimos años del siglo XX estudiosos europeos y principalmente de la escuela francesa se han ocupado de la diferencia entre esclavos y cautivos. Podemos citar entre otros Wolfgang Kaiser $(2006,2008)$, que analiza la cuestión del uso del término cautivo. No pudiendo entrar aquí en mérito a la distinción jurídica y terminológica sobre cautividad y esclavitud, queremos solo advertir que usamos fielmente la terminología de las fuentes consultadas, en las cuales con frecuencia emplean indistintamente los dos términos, como se puede ver, por ejemplo en el Diálogo de la captividad y en el Diálogo de los mártires (vid. Nota 14). Ambos convivían en los baños: "Son también de notar los que llaman baños del Rey, que son las casas, corrales para mejor decir, do tienen sus esclavos y captivos cristianos encerrados" (Topografía, cap. 39, f. 42r). En la Información de Argel que Cervantes hizo de los cinco años que estuvo cautivo, habla siempre en términos de cautiverio, en cambio el escribano y notario Pedro Ribera que la recibe habla de esclavitud: "En la ciudad de Argel, que es tierra de moros, en la Berbería, a 10 días del mes de octubre, año de 1580, ante el ilustre y muy reverendo señor fray Juan Gil, redentor de España de la corona de Castilla por su majestad, (com)pareció presente Miguel 
cautivos, ya hemos visto que en el Epítome se afirma que a los quinientos que tenía en su casa los trataba como si fueran hijos y Cervantes, por boca del Cautivo, recuerda que "moralmente fue hombre de bien, y trataba con mucha humanidad a sus cautivos, que llegó a tener tres mil" (I, XL). También el bailío Bernardo confirma que sus esclavos eran muy bien tratados, pero al mismo tiempo precisa que eran tenidos tan estrechos y desesperados de obtener su libertad que cuando murió muchos sintieron gran alegría pensando que al pasar a ser propiedad del sultán conseguirían más fácilmente su libertad, a través de una venta o de la fuga. Con los no renegados, en cambio, con frecuencia se mostraba implacable y cruel, incluso parece que gozaba con sus sufrimientos. Leyendo la relación del Epítome sobre la vida de los cautivos de Argel se tiene la impresión de que, en ciertos casos, actuaba así para que nadie sospechase que su conversión al islamismo era solo de apariencia. En el Diálogo Primero, titulado De la captividad de Argel, ${ }^{14}$ los dos interlocutores, Antonio y Sosa, hacen una crónica detallada de la vida de los cautivos y su relato es un valioso testimonio del comportamiento de Uchalí con ellos. Hablando por ejemplo de la crueldad de los cómitres (todos turcos o renegados) para con los cristianos, sobre todo cuando se emborrachaban, Sosa recuerda lo que le habían contado que hizo Uchalí con un caballero de la orden de Malta que había capturado en 1569:

"Lo mismo me contaron que hacía ese sucio renegado Ochalí, Calabrés tiñoso, (a quien esta canalla tiene y estima por único, y rarísimo hombre del mundo) que fue General del Turco en la mar. Porque

de Cervantes - esclavo que ha sido, que ahora está franco y rescatado- y presentó el escrito de pedimiento siguiente, con cierto interrogatorio de preguntas"(2019). Tampoco es fácil saber cuando un renegado deja de ser esclavo, pues aunque al "tomar el turbante" queda exento de los trabajos más penosos por ser impropios de los hijos del profeta, no por eso deja automáticamente de ser esclavo, pero sí puede tener más oportunidades de conseguir su libertad. El caso de Uchalí que cautivado en Calabria es vendido como esclavo, se convierte en renegado y recobra su libertad, no es único en la época.

14 Este diálogo se configura como un tratado sobre la esclavitud en el que se hace su historia como aparece claro ya en el Argumento: "Entrando Antonio González de Torres caballero de San Juan, a visitar al Doctor Sosa su amigo, en las prisiones en que está captivo, y encarcelado, tratan los dos cuan infelice suerte sea la del captiverio, cuando tuvo principio el uso de hacer a los hombres esclavos, quien fue el autor de tan bárbara costumbre, de que manera y calidad era el captiverio, de que usaron antiguamente muchas naciones, y finalmente, de las grandes miserias, trabajos, tormentos y martirios, que hoy día padecen los captivos cristianos, en poder de moros y turcos, principalmente en Argel" (f. 96r). En adelante citaremos este diálogo como De la captividad, cuyos parágrafos se llaman "Divisiones". 
habiendo tomado entre otros a un caballero italiano, de nuestra Religión, cuando se perdieron sobre la Licata en Sicilia, las nuestras tres galeras de Malta: después algunas veces estando borracho, o (como otros dicen) cada día, decía a grandes voces: tomen aquel perro de San Juan, y denle 200 palos a la hora. De esta manera asiendo dél por los pies y manos; y echado de pechos sobre crujía, desnudo; si el Ochalí le mandaba 200 pasos, o azotes, le daban 300 y más; estando el Ochalí mirando esto en popa, riéndose muy contento de oír las voces del mezquino caballero" (ff. 117v-118r).

En otra ocasión, siendo ya Capitán General del Mar, le llevan a un cristiano que había matado a su amo y Uchalí, oyéndole contar que lo había hecho porque no podía soportar más las crueldades y maldades del patrón, y viendo la serenidad con que aceptaba su segura condena a muerte, se maravilla de la entereza del cristiano y se queda suspenso sin saber qué hacer. Probablemente hubiera querido perdonarlo, pero ante la presión y gritos de los parientes y amigos del muerto y quizás también por el temor de que pensaran que era tolerante con un esclavo cristiano, ordenó:

\begin{abstract}
"que con una maza de hierro (como se acostumbra entre ellos) le rompiesen todos los miembros, como brazos, piernas, espaldas y costillas. Y que desta manera le dejasen allí en mitad de la calle, que va de la aduana hacia el baño de los esclavos de Aluchalí para que con el tormento acabase de morir penando y los esclavos con mirarle escarmentasen" (f. 132r).
\end{abstract}

En el diálogo segundo titulado De los mártires de Argel, ${ }^{15}$ Gerónimo Ramírez y el doctor Sosa hacen un recorrido por la historia de los mártires y,

15 El Segundo de los Diálogo, De los mártires de Argel (en adelante Mártires), que tiene lugar entre Gerónimo Ramírez y el doctor Sosa, empieza con una breve introducción, o argumento, donde se da cuenta sintéticamente de su contenido: "Visitando el capitán Gerónimo Ramírez al Doctor Sosa su amigo en las prisiones, en que está cautivo; de un libro que le vio en las manos, tomaron ocasión de tratar, cuan provechosa cosa sea para todos, particularmente para cautivos, la lección de buenos libros, y en especial la vida de los Santos y Mártires de Dios. Y a este propósito se trata la vida del bienaventurado San Paulino, que en otro tiempo fue cautivo en Barbaría, y de los diversos modos, con que los tiranos y gentiles en otro tiempo mataban y atormentaban los cristianos, y cuéntanse también algunos martirios, y otras muchas y muy crueles muertes que turcos y moros han dado de pocos años acá a cristianos en Argel" (f. 144r). Después de un recorrido por la historia de los mártires cristianos pasa a tratar de los de Argel, donde es verdad que hay muchos renegados pero mirando bien, dice, se hallarán "aun más de siete mil otros que no solo no se han arrodillado ante Baal, pero admirablemente con su fe, vida y costumbres cristianas, y con una constantísima paciencia y esfuerzo, más que humano en los grandes trabajos y miserias que padecen, glorifican y honran en sí mismos y en sus cuerpos, a nuestro Señor Jesu Cristo" (f. 152v). 
al detenerse en la situación de Argel, Sosa dice a su interlocutor que para constatar lo que sucede allí basta que "eche los ojos por todos esos baños y casas, tanto deste bárbaro rey y tirano, cuanto de todos esos cosarios, turcos y moros, que número tan grande hallara en ellas"; sigue después la lista de las varias categorías de eclesiásticos, hombres de letras, soldados y personas de distintas lenguas y naciones:

"Y tantos otros infinitos cristianos, de toda nación, suerte y condición los cuales, como es lástima y piedad grandísima, verlos en tantas cárceles, tantas cadenas, tantas traviesas, y aun tantas mazmorras y martirios, apaleados, hambrientos, enfermos, desnudos, angustiados, aflictos y perseguidos del mundo, que realmente no es dellos digno" (152v).

De todo ello, ha tomado buena nota Sosa en unos papeles en los cuales con todas las diligencias del mundo ha ido anotando, como dice a su interlocutor, las informaciones recibidas de cristianos, renegados, turcos y moros sobre las crueles muertes de los cristianos desde el tiempo de Barbarroja hasta ese momento. Estos papeles, que Sosa da a Ramírez para que los lea, titulados Memoria de algunos martirios y otras muy crueles muertes que, estos años atrás, algunos cristianos han recibido, particularmente en Argel de los infieles turcos y moros, ilustran bien el trato que recibían los cristianos que no querían renegar de su fe. Damos solo tres ejemplos que ponen de relieve dos modos diversos de actuar de Uchalí. El primero se refiere a un episodio que tiene lugar el mismo año en que fue nombrado rey de Argel, el segundo al año sucesivo, y en ambos Uchalí da muestras de una crueldad inusitada; el tercero tiene lugar unos años después de la batalla de Lepanto, cuando ya era General del Mar y se nombraba Kiliç Alí Bajá, y su comportamiento es mucho más tolerante.

La primera historia tiene como protagonista a un mozo italiano llamado Gerónimo y sucedió a primeros de octubre de $1568,{ }^{16}$ pocos meses después de que Uchalí fuese nombrado rey de Argel. Había allí un italiano que siendo muy mozo le habían obligado a renegar su religión a la que luego volvió y que, tratando de huir de Argel para refugiarse en la cristiana Oran vestido de turco, le detuvieron unos árabes sospechando que era cristiano

16 Siete meses antes había llegado a Argel como gobernador: "El Piali, para gratificar estas buenas obras, hizo tanto que acabó con el Turco, como estando descontento del Mahamet Bajá, por lo que usara con los moros de Constantina, le enviase en su lugar por Rey y Gobernador de Argel: llegó como dijimos, a Argel en principio del mes de marzo del año de 1568" (Epítome, f. 78r). 
y al regístralo y no encontrar licencia alguna del rey lo prendieron y lo llevaron ante Aluch Alí. Interrogado por éste, confesó que era cristiano y que le habían obligado a renegar, pero que él quería seguir siendo cristiano y que por eso iba a tierra de cristianos; el rey, viendo su firme decisión de mantenerse en su fe, mandó que le llevaran al patíbulo y le desnudaron completamente y para burlarse de él los chauzes "le vistieron un coleto viejo de cuero y muy sucio, diciendo: que ahora con aquel vestido era cristiano y estaba muy galán y bizarro soldado". Luego le dieron muerte de la manera más cruel, según acostumbraban:

"Desta manera atándole por la cintura con soga, que conforme a lo que atrás otras veces habemos dicho colgaba de la garrucha, o polea que está en lo más alto de la horca, le alzaron hacia lo alto, y dejándole caer como es uso, con gran ímpetu abajo, y de golpe, en tocando al gancho, que abajo estaba con la punta hacia arriba muy grande y muy aguda, fue traspasado fieramente del, por el estómago, y de tal suerte, que la punta le salió por las espaldas" (f. 171v).

Y así lo dejaron tres o cuatro horas hasta que murió, es decir, desde el mediodía del 22 de octubre de 1568 hasta las cuatro cuando terminó de espirar.

Un año más tarde corrió una suerte parecida un moro que de niño había sido cogido en una razia y se convirtió al cristianismo y luego fue cautivado por los moros y llevado a Argel, donde quisieron que se convirtiera de nuevo al islamismo, pero él se mantuvo fiel en la fe de Cristo. Entonces, para que sirviese de ejemplo, Aluch Alí concibió para él una muerte cruel, murarlo en un bastión del fuerte que estaban haciendo para defender el embarcadero, cosa que ejecutaron de esta manera:

"No serían bien las tres horas del día y las nueve, como en España contamos, que entraron por el baño tres o cuatro ministros chauzes del Rey, y preguntando por Gerónimo, que estaba en la iglesia encomendándose a Dios, el mismo salió a ellos; los cuales como le vieron, luego como es de su costumbre, comenzaron con mucha braveza decirle mil afrentas y injurias, de cane, perro, cornudo, judío, traidor, ¿que por qué no quería ser Moro? A lo cual todo el siervo de Dios, no respondió ni aun una pequeña palabra. Los chauzes le tomaron en medio y caminaron con él hacia el fuerte o bestión (sic) que dijimos, donde el Rey le aguardaba, y había de ser su dichosa fin y muerte. Llegado pues a este lugar, y presentado delante del Rey, que 
estaba muy acompañado de renegados y Turcos, díjole el Rey estas palabras: Bre juppe, que quiere tanto decir, como Ola perro, ¿̇por qué no quieres tú ser Moro? Respondióle el mártir de Dios: no lo seré por ninguna cosa, cristiano soy, y cristiano tengo de ser. Replicóle el Rey: Pues si tú no te vuelves moro, allí (señalando el lugar de las tablas que dijimos con el dedo) te tengo de entapiar vivo. Respondióle el varón santo, con singular y admirable esfuerzo: Haz lo que quisieres, que aparejado estoy para todo: y ni eso me hará que deje la Fe de mi Señor Jesu Cristo. Visto por el Rey su grande ánimo y esfuerzo, y que tan constante estaba en la Fe de Jesu Cristo, mandó luego le quitasen la cadena que tenía a la pierna, y que atado de pies y manos le metiesen en el hueco de las tablas de la tapia, que mandara reservar el día antes; y vivo le tapiasen. Hicieronlo así los Chauzes. Y metido entre las tablas así ligado: un renegado español de casa de Agí Morato, el cual en cristiano se decía Tamago que cautivara en la pérdida de Mostagán con el conde de Alcaudete, y en Turquesco se decía lafer, saltó luego a pies juntos, sobre el mártir de Dios: y tomando en las manos uno de aquellos pistones que allí estaban, pidió con grande instancia, que trujesen presto la tierra: como trujeron, y echándola sobre el santo de Dios, que ni hablaba, ni abría su boca, más que un corderito manso, comenzó el renegado a dos manos con gran fuerza a pistar, dando con el pistón grandes y crueles golpes, lo cual viendo otros renegados de muchos que allí estaban con el Rey deseosos también de que los tuviesen a ellos por buenos y finos turcos, arremetieron también a otros pistones y cargando la tierra que se traía, y ellos pistando a toda fuerza y furia, acabaron de hinchar el hueco de las tablas, y de matar al glorioso mártir de Cristo, cuyo espíritu, conforme a nuestra santa fe, habemos de tener, que le recibió el Señor en el número de sus santos en el cielo, y que le dio la corona y premio desta santa y gloriosa muerte. A todo esto estaba presente el Rey y una infinita cantidad de Turcos, renegados, y Moros, mirándolo con gran contento y gusto. Lo cual hecho y quedando el cuerpo del santo varón sepultado en tan noble sepulcro, dio la vuelta el Rey para su casa, y decía por el camino, que realmente no pensara que aquel Cristiano recibiera la muerte con tanto ánimo. Sería entonces mediado Setiembre, del año mil y quinientos y sesenta y nueve" (f. 173r).

Al lado de episodios de crueldad extrema, como los que acabamos de citar, Sosa narra otros en los que Uchalí se muestra mucho más transigente. Tal es el caso del tercer episodio que hemos elegido como ejemplo, es de- 
cir, el de un acusado culpable de rebelión y asesinato contra su dueño. El 4 de febrero de 1577 los cristianos cautivos del corsario argelino Car Asán, que era muy cruel con ellos, estando en el río Tetuán, pensando que por la cercanía de España podrían escapar más fácilmente, se amotinaron hiriendo mortalmente al arráez. Pero fueron atacados por otra galeota mandada por Mamí Arráez, renegado de Car Asán, el cual ejecutó cruelmente a los mayores responsables:

"a Janeto el carpintero que había matado a Car Asan con la hacheta le cortan las orejas y las narices, le ahorcaron de los pies en la punta de la entena, y tiraron un gran número de flechas de forma que quedó como un erizo. Y luego le dejaron caer en el agua donde estuvo un gran cuarto de hora, después, creyendo que estaba muerto lo izaron y vieron que estaba vivo y lo tuvieron colgado como media hora hasta que murió. A Juliano le dejaron en calzones, le ataron atrás las manos y lo enterraron en la arena de la playa hasta la cintura y le arrojaron tantas flechas que todo el cuerpo quedó cubierto de ellas y luego echaron los cuerpos al río" (178v).

Pero, no conforme con esto, fueron a Argel para pedir justicia sobre los otros cristianos que creían más culpables. El rey dio licencia a Mamí Arráez para que atasen a Andrea laca a un caballo y lo arrastrasen por las calles de la ciudad hasta que, casi muerto, lo arrojaron desde la muralla donde quedó clavado en un gancho y murió; a Marcelo el calabrés lo ataron en un grueso palo donde le apalearon hasta romperle la cabeza y los miembros, y luego lo quemaron; al siciliano Marco Remolar lo ahorcaron los pies de una saetía donde estuvo colgado un día entero y al día siguiente lo echaron al mar. Y no satisfecho, pues quería matar a la mayor parte de los cristianos que habían tomado parte en la rebelión, Mamí Arráez fue a Constantinopla donde, junto con la mujer y los hijos de Car Asán, pidió a Aluchalí, que entonces era capitán general del mar, que hiciese justicia:

"pero el Aluch Ali, como hombre experimentado y cortido en las cosas de la guerra, y casos ordinarios della, no lo quiso consentir, antes les dijo, que fuera demasiada la venganza que tomara el Mamí Raez en Tetuán y Argel. Y mostrándoles el brazo derecho, que tiene estropeado les dijo: Veis aquí este brazo que cristianos esclavos, alzándose con un bajel mío en otro tiempo, y dándome muchas heridas por matarme y poder haber libertad, me estropearon, y ultra de esto se me han alzado con otros dos bajeles míos, y matado muchos turcos por alcanzar su libertad: y de todo no me he maravillado, porque todo 
cautivo y esclavo obligado es buscar modo y manera como salir de su cautiverio, y esta es la usanza de la guerra, y pues no solo fue Car Asan a quien esa suerte cupiese, quitaos desa demanda, y de querer matar a los pobres cristianos. Con estas y otras razones que les dio, los quietó el Aluch Alí: y les dijo muy llanamente la verdad, de cuan injustas crueldades fueron aquellas, que el Mamí Raez había hecho; juzgando que para dar tales muertes a cristianos no había causa justa ni bastante" (ff. 178v-179r).

El discurso que hace Uchalí en este caso, cuando está en la cúspide del poder, contrasta con su modo de proceder anterior, ya nadie puede dudar de su adhesión al islamismo pues ha demostrado suficientemente su aceptación contribuyendo de manera decisiva a la expansión del imperio turco y rechazando las halagüeñas promesas de los estados cristianos para que se pusiera a su servicio, por lo que no teme que puedan acusarlo de favorecer a los enemigos del islam. Pero sobre todo es significativa la afirmación de que los cautivos y esclavos están obligados a buscar el modo de ser libres, es una guerra y en la guerra se muere. Y pone como ejemplo lo que le acaeció a él mismo quince años antes. El episodio al que se refiere tuvo lugar en 1562, los documentos conservados en el archivo de Simancas dan minuciosa cuenta de lo ocurrido. Transcribimos la primera relación:

\section{"En Mecina a XII de Agosto 1562}

Relación de la galera capitana que fue del gran capitán Aloxalí la qual le fue levada de ocho renegados que son Paulo genovés de Onella, Hércules francés de Turs, Nicolo de Nixsia griego, Antonio de Cofando griego, Josep de Mendoça spañol, Demitrio griego de Nillo, Juan borgoñón, Luis spañol de Castro de Urdiales, Jac. ${ }^{\circ}$ Antonio de Otranto.

Dicen que estuvieron en Xio [Quíos] diez días son que fue los dos de agosto con Xx galeras capitanes de las quales eran Alli Portuch con las cuales era Aloxalí capitán de fanal el cual estaba destinando de ir con xv galeras de aquellas, o de otras que se speraban de Costantinopla para ir en Argel con la persona de Aser Baxa hijo de Barbaroxa que iba por Rey de Argel y que había de ir Aloxalí por capitán dellas y estas xx galeras andaban guardando el arcipiélago.

Que había hasta 40 días que trataban entre los ocho sobredichos de buscar ocasión de matar al Aloxalí y alzarse con la galera y que habían dado parte a algunos cristianos de la misma galera de los que más se fiaban. 
Que estando en Xio donde estuvieron VIII días y partiéndose de allí a 2 de Agosto a Complazecia de la tierra por el daño que les hacían se fueron al canal de Xio que es doze millas largo donde surgiendo la dicha galera vna milla más delante de las otras, se ofresció ocaisón que el capitán envió xx turcos en tierra en la propia isla de Xio a hazer carne y quedando hasta 120 entre renegados y turcos tomaron las armas y saltaron a la popa tres que son Paulo genovés, Hércules francés y Nicoló de Nixsia, los cuales mataron a Aloxalí con los que estaban en la popa y los echaron a la mar aunque se defendieron y hirieron al genoués en un brazo, y ansí hicieron en la proa Antonio de Cofando, Demitrio griego y Ja. ${ }^{\circ}$ burgoñón y los dos spañoles ayudaban donde era más menester y los forzados con las armas que se hallaron con puntales y babetas hizieron lo mismo contra los turcos y mataron más de 40 y los demás se echaron a la mar y ansí se alzaron a XXIl y dieron cargo de padrón de la galera a Phelipo Rizo de Crapi (sic) uno de los forzados y a Paulo Corso del cual se fiaron desdel principio más que de ninguno porque tenía la camera del medio en sus manos, y a otros hasta VIII dieron cargo de la galera para gobernalla que son Jo Celesti de Consençia, Baptista genoués, Franc.o de Nuza de Trápana, Baptista Perín genoués, Bernardino de Belneda, Renaldo de Seminara y Guillemo de Arbizora. Las galeras de enemigos les començaron a dar caza pero viendo que la galera era muy buena y caminaba mucho y la hora era tarde volvieron y no las vieron más y sin tocar en ninguna parte han venido en 9 días de Xio a Mecina.

Hay hasta 12 spañoles y hasta 32 genouenes y de otras naciones hasta en número de 160 cristianos entre todos. La galera es nueva de VI meses que ha que la echaron a la mar en Costantinopla, viene muy bien artillada y xarciada y muy bien en orden de todo lo necesario". ${ }^{17}$

17 AGS, Estado, leg. 1127-69. Esta relación va alegada a una carta del duque de Medinaceli a Felipe II del 18 de agosto de 1562 desde Monreale (Palermo) en la que, entre otros asuntos, habla de la presa de la galera de Uchalí y de su supuesta muerte: "La galera era de Uluchaly, de quien ya Vuestra Majestad debe tener noticia que era un renegado calabrés que ha mucho tiempo que era capitán de las galeras de Dragut y que hacía salidas por estas (sic) mares y el que fue cuando tocamos en los Gelves la primera vez a Costantinopla y truxo el armada de que ganó tanto credito y junto con ser valiente y experimentado, que había llegado a ser de mucha estimación entre los turcos y le habían dado fanal que es gran comienzo para ellos, ha sido de muy gran importancia su muerte porque fuera un muy dañoso perro para cristianos y a estos dos reinos que les tenía muy bien entendidos". Sigue diciendo que ha mandado que se compre la galera para su Majetad por ser la más hermosa que se ha visto, la mejor de la vela y el remo y también ha ordenado que se recompense a los que se alzaron contra Uchalí pues piensa "no solo por haber muerto un hombre de tanta importancia y haber salvado tantos cristianos mas porque es dar ánimo a los que allá quedan para venirse, que se yo que 


\section{UCHALI EN LA LITERATURA}

\section{Uchalí en las crónicas de Jerónimo Costiol y Fernando de He- rrera}

En 1572 Jerónimo Costiol, autor del que se conocen pocas noticias, ${ }^{18}$ publica una Crónica de la batalla de Lepanto (1572) en la que, como no podía ser de otra forma, dedica un amplio espacio al renegado calabrés que el cronista denomina Ochalí, aunque a diferencia de Herrera no hace ninguna referencia a su pasado de esclavo. En el capítulo XIII del libro II, se incluye un dibujo sobre la disposición de la batalla en el que se ven claramente las naves mandadas por Ochalí, junto a las de Caracossa, frente a la escuadra mandada por Andrea Doria.

En el capítulo XIV del libro II se habla de Ochalí destacando su capacidad de estratega, pues, prudentemente, pone en duda que las fuerzas de la armada cristiana fuesen tan reducidas como había informado el Corsario Caracossa quien, en su viaje de reconocimiento, seguramente no había podido ver todas las naves de la Liga que quedaban ocultas detrás de un promontorio.

"Ochalí empero gobernador de Argel, oyendo esta relación no la creyó: antes dixo que no era posible que los cristianos fuesen en tan poco número, porque por muy segura inteligencia sabía que era mucho mayor su armada, y que por ventura no lo había bien reconocido. Pero replicando el cossario, dixo que él lo tenía muy bien mirado, y que no se detuviesen por cosa alguna de salirles al encuentro, porque en una coyuntura como esta podían ganar mucho crédito, y aprovecharse bien. Partau, Bassan de tierra, fue de contrario parecer, concordando con el Ochalí diciendo que la Liga de tres potencias, con mayores fuerzas habían de venir: y que mirasen muy bien lo que determinaban, y que no era tiempo de tentar la fortuna en cosa incierta, esto es o sabiendo averiguadamente el número y poder de los cristianos, y que por tanto fuera mucho mejor estarse en el golfo de Lepanto, y aguardar allí a ver lo que sería" (ff. 58v-59r).

entendiendo que se haze bien con ellos haurá muchos que lo hagan y causará otra cosa de mayor consideraçión que será hazer odiosos y sospechosos a los Renegados con los Turcos que es la gente que más vale dellos, a lo menos en la mar" (AGS Estado leg. 1127-70). Pero la noticia de la muerte resultó ser falsa. Hay numerosos documentos en el AGS (legs. 1127 y 1128 ) relativos a la supuesta muerte de Uchalí y a los esclavos que se amotinaron contra él.

18 Sobre Costiol cf. LÓPEZ DE TORO, 1950. 
Pero cuando parecía que iba a prevalecer el consejo de Ochalí y de Partau, se levantó el turco Haly Aga diciendo que el mandato de Selin era pelear y que quien no estuviera de acuerdo se atuviera a las consecuencias cuando el Gran Señor examinase a los culpables, por lo que «Partau, Ochalí, y otros baxaes y capitanes, oyendo la repugnancia deste turco, y cuan zacudidamente lo trataba, determinaron por no parecer de menos ánimo, ir adelante» (L. II, c. XIV). Después, se describe la disposición de la batalla y se especifica que «El siniestro a la parte de mar llevaba el Ochalí gobernador de Argel, con Caracossa capitán de mar, según más claramente parecerá en la tabla siguiente». Inmediatamente, como ya se había hecho para los cristianos, se pone la tabla de las 230 galeras turcas y, según la lista, siete eran de Ochalí, el cual además aportó 12 fustas y 90 bergantines.

En la minuciosa descripción de la batalla, que ocupa varios capítulos, el cronista dedica amplio espacio a la acción llevada a cabo por Ochalí que en el lado del mar estaba dando grande trabajo a las galeras cristianas que mandaba Andrea Doria. En la descripción de la encarnizada lucha y los daños en ambos bandos, el narrador enfoca la acción de Ochalí, que con saña ataca las galeras malteses de San Juan de Jerusalén poniendo en grave peligro a su capitán el prior de Mesina, fray Pedro Justiniano:

"Porque teniendo Ochalí apretadísimo al Prior Justiniano, no peligró más su persona, de cuanto tardó a llegar don luan de Cardona con su galera. En la cual llevando al Marqués de Ávalos, y a don Henrique de Cardona a costa de mostrar solamente allí su cara, fue el maltés librado de muerte, de la cual ya no podía escusarse: porque el renegado Ochalí, con él, más que con otro quiso emplear su saña: y así hallándose no más de su persona sola con otros cuatro caballeros, le mataron todo el resto de su armada" (f. 67v). ${ }^{19}$

La oportuna llegada de la escuadra de socorro al mando de Juan de Cardona, capitán general de las galeras de Sicilia, salva al prior mesinés de la crítica situación. Más adelante, vuelve sobre el ataque del renegado calabrés a Fray Pedro Justiniano: «Y al Prior fue forçado dar razón a las galeras de Ochaly, que como está dicho cargaron sobre él» (L. II, c. XX).

19 Cervantes relata así el mismo episodio: "habiendo el Uchalí, rey de Argel, atrevido y venturoso cosario, embestido y rendido la capitana de Malta, que solos tres caballeros quedaron vivos en ella, y éstos mal heridos, acudió la capitana de Juan Andrea a socorrella, [...] Y como ya habréis, señores, oído decir que el Uchalí se salvó con toda su escuadra" (Quijote, I, XXXIX). 
La grave situación en que se encuentra Juan Andrea Doria se resuelve con la llegada de Barbarigo que enfrenta sus naves a las del corsario calabrés:

"Y hallando al señor Andrea muy apretado de Ochalí, y otros turcos sin él, que le habían desarmado de siete galeras, entró valerosamente en su socorro, y hizo retirar algún tanto al porfiado cossario. El cual no queriendo desde entonces abordar con alguno, peleaba con arcabuceros y flecheros aspérrimamente. Donde siendo herido de una dellas Barbarigo en un ojo, cayó por el pizuelo abaxo. Pero no por eso dexó su escuadra de pelear, porque como su Alteza andaba también por allí de una parte a otra, socorriendo donde vía que más era necesario, todo el mundo se movía muy bien. Ochalí a esta sazón volviendo los ojos a la real de España que con valentía lo andaba todo, y acabando de entender que la suya era perdida: entonces quiso abordar menos. Y así poco a poco arrimándose a la siniestra mano donde Barbarigo había peleado de primer encuentro, comenzó disimuladamente a ganar mar, para huir. Y acabando de ver casi la total destrucción de los suyos, comenzó gentilmente de hacer trinquete, para doblar una punta que a la parte de tierra estaba. Lo cual como viese su Alteza y el marqués de Santa Cruz, quisieron correr adelante para ganársela: y así fue forçado al enemigo envestir en tierra con algunas de las galeras que llevaba, de las cuales muchos turcos se escaparon a nado. Finalmente saliendo el Ochalí con parte de la banda que tras el iba, y rindiendo el señor Andrea las que quedaron sin escaparle una: la noche puso fin a la victoria, habiendo durado el sangriento conflicto desde las diez antes del medio día, hasta las cinco de la tarde" (f. 72v).

Es decir termina la relación de la victoria con la imagen de Ochalí escapando del escenario de la batalla con las galeras que pudo salvar.

En el capítulo IV del libro tercero, haciendo el recuento de las pérdidas turcas, nombra entre los muertos al hijo de Ochalí, Carabey, que era gobernador de Vzinith.

El papel relevante de Ochalí es puesto de relieve cuando, después de la derrota, Selín II consultó con algunos turcos expertos en las cosas de la guerra cómo poner remedio al desastre sufrido y ellos le aconsejaron "que pospuesto todo su enojo, que enviase por Ochalí que volviese con seguridad, para que venido ante él, se pudiese tratar mejor del remedio del negocio". Y así se hizo mientras "el Ochalí a esta sazón se entendió que estaba en Modón con siete galeras, herido de dos arcabuzazos y aguardaba orden 
del gran Señor que era lo que debía hacer: por eso de ir a Constantinopla, no sé yo si con todas las seguridades que el turco le podía dar, se tuviera él por muy seguro" (f. 86r).

El año sucesivo a la Batalla de Lepanto el poeta Fernando de Herrera escribe una obra en prosa titulada Relación de la guerra de Chipre y suceso de la batalla naval de Lepanto (1572). ${ }^{20}$ Aunque, como el mismo dice en la "Dedicatoria a D. Alonso Pérez de Guzmán duque de Medina Sidonia y conde de Niebla" no fue testigo de los hechos, su relato se basa en las narraciones de los que estuvieron en la batalla. Sin embargo, aun teniendo "grandísimo cuidado y diligencia" de elegir lo que le parece más razonable y lo que más concordaba entre las numerosísimas relaciones que llegaron a sus manos, e incluso preocupándose de interpelar a los que intervinieron en los hechos, es consciente de que es incierta la "verdad traída de partes tan remotas y de lenguas tan varias, y que todo no puede estar tan ajustado". Por eso, a veces, cita las fuentes de su relato y con frecuencia deslinda lo que le dicen de lo que piensa. Tal es el caso de la breve presentación que hace del calabrés al narrar el encuentro entre Ochialí y Alí Baxá en Negroponto cuando aquél, que entonces era virrey de Argel, había ido allí para limpiar el fondo de la nave y engrasarla. De hecho, el poeta sevillano dice que ese corsario renegado era "de nación calabrés, natural de Castelo lugar arruinado por Barbarroxa, que según dicen algunos que han estado en él", y luego, sin justificación alguna, añade: "yo pienso ser por ventura Castro, lugar en la costa entre el cabo de Santa María y Otranto, ocho millas distante del dicho puerto"(1572: XIV). Es decir, recogiendo la opinión de los pocos autores que sostienen que Uchalí era de Apulia interpreta el nombre Castello como Castro y no como Le Castella. Inmediatamente dice: "Que lo saquearon Lustimbey y Barbarroxa cuando iba con ellos Troylo Pinatelo en el año de treinta y siete y se llevaron presa toda la gente" (1572: XIV). De lo que podemos deducir, aunque no lo explícita, que Herrera considera erróneamente que la captura de Uchalí tuvo lugar en ese asalto a Castro que, efectivamente se hizo en julio de 1537, cuando Barbarroja instigado por Francisco I de Francia puso asedio repetidamente a esa ciudad situada en la punta donde se unen el Adriático y el golfo de Tarento.

Luego, hace referencia a las incursiones que Uchalí lleva a cabo por el Mediterráneo saqueando las localidades costeras y cautivando a sus habitantes:

20 La obra, publicada en 1572, carece de numeración, así pues en las citaciones además del año, ponemos entre paréntesis el capítulo correspondiente. 
"A este [Uchalí] por ser famoso entre los cosarios, y por la confianza que se hacía de su valor, envió a mandar el mesmo Selín desde Constantinopla [...] para que se juntase con su armada. Y obedeciendo su orden, salió de Argel, saqueando de camino todos los lugares de la costa, y con grande número de cautivos llegó a su armada" (1572: XIV).

Y sigue nombrando todos los lugares costeros por los que pasaba, precisando que en la isla de Candia llegó a cautivar a más de ochocientas personas y los mismos daños hizo en Zante y en Chafalonia de donde se llevó a más de "seis mil cautivos". También conquistó Corfú a los venecianos; y también tomó Dulcino, Buda y Antivari y salió de esa costa con más de "cuatro mil esclavos", aunque perdió cuatro galeras por una borrasca. Pero no consiguió hacer lo mismo en Cataro defendida con mucha gloria por Mateo Bembo.

Por lo que se refiere a la batalla de Lepanto, como todos los autores, Herrera resalta la importancia de Uchalí en la contienda. De hecho, en el capítulo sobre Los preparativos de la Liga y como los turcos tratan de reforzar su armada, leemos que Ochalí sacó de Modón más gente : "Que serían todos casi veinte y cuatro mil hombres. Porque (según afirma el comentador Romagaz) ${ }^{21}$ se había informado de Caracial y Caracossa, que tomando lengua en Calabria de la armada de la liga, volvieron con relación della al Baxá el que traía la más poderosa armada, que jamás la potencia Otomana pudo meter en mar" (1572: XXIII).

$Y$ en el capítulo XXVI, antes de entrar en el vivo de la batalla, Herrera escribe que los turcos no toman en serio a sus enemigos pues «al principio no podían descubrir todo el número de sus galeras, cubriendo una montaña casi la tercia parte dellas". E insiste en la prudencia de Uchalí que aconseja mirar bien lo que van a hacer pues las galeras Ponentinas, como suelen llamar a las de Felipe II, eran muchas, pues no era creíble que el rey mandase a su hermano a combatir sin fuerzas suficientes pero, al final, acata la orden del Baja de ir a combatir.

Luego Herrera presenta la formación y disposición de las dos escuadras. El escritor afirma que Uchalí aporta siete galeras, doce galeotas, y que guiaba el cuerno diestro opuesto a Juan Andrea Doria, con su hijo Carabey.

21 Seguramente se trata de Mathurin d'Aux de Lescout, conocido como Mathurin Romegas, noble gascón, miembro de la orden de San Juan de Malta, que fue uno de los comandantes navales más importantes de la Orden en la batalla de Lepanto, en la que combatió en el buque insignia papal bajo el mando del almirante Marco Antonio Colonna y era el superintendente de las galeras papales. 
Relata, además, la estrategia de Uchalí que se había alargado tanto "con el cuerno siniestro, que hubo duda que no quería pelear y pareció, que era su intento cerrar a los cristiano dentro de su escuadrón" y como Doria, dándose cuenta de la maniobra del renegado, contraataca. Herrera, no parece apreciar mucho la maniobra de Uchalí que achaca no a una sabia estrategia del calabrés, sino más bien a su intención de rehuir el combate con Andrea Doria cuya nave había reconocido por el fanal, pues dice: "Mas aunque Juan Andrea lo procurase mucho, rehuyó siempre Uchalí encontrarse con él, de suerte que ambos se hallaron siempre en parte diferente". Más adelante comenta: "Ochialí, que según muchos afirman, nunca peleó con su galera, viendo que llegaba socorro a la de Malta, se retiró a la batalla, y hallando todas las cosas en desorden, huyó con el estandarte de la Religión". Herrera contrapone el comportamiento heroico del genovés al cauteloso de Uchalí que parece que lo único que pretende es evitar entrar en batalla con un rival al que teme por su fama y escapar con vida, aunque no sin antes haber atacado duramente a la galera de Malta.

Aunque no ha sido testigo de los hechos, Herrera afirma persiguir la verdad con más empeño que nadie, cotejando todas las relaciones que conoce para dar la que cree mejor versión de lo acontecido en la batalla; en el caso de Uchalí no parece que esto sea así, pues no solo elige la versión equivocada por lo que se refiere a su patria y cautiverio, sino que también parece que quiere dejar en sombra la victoria parcial conseguida por él en Lepanto.

\section{Uchalí en los textos poéticos de Pedro Manrique, Jerónimo Costiol y Jerónimo Corte Real}

Hay dos poemas manuscritos dedicados a la Batalla de Lepanto, La naval y La victoria que tienen por autor a Don Pedro Manrique. El primero, un volumen encuadernado en pergamino con el título y el autor solamente en el tejuelo y sin ningún tipo de título o autoría en el texto, se conserva en la biblioteca Nacional de Madrid (Mss 3942); el segundo, con elegante encuadernación en piel con el escudo de Castilla (aunque bastante estropeada), además de en el tejuelo, tiene también en la primera pagina el título y el nombre del autor, Pedro Manrique, el cual firma la dedicatoria a Don Juan de Austria en Burgos a 20 de abril de 1573. Este segundo códice forma parte de los fondos españoles de la Biblioteca Mazarine de París (Ms

22 No es ésta la sede para hacer un análisis cotejando los dos manuscritos que nos permitiría avanzar hipótesis sobre la relación de dependencia de ambos textos, así pues nos limitaremos a decir que creemos plausible que La victoria sea una nueva versión, casi una reescritura, quizá para la imprenta, de La naval. 
1843). ${ }^{22}$ En los dos casos hay suficientes indicaciones explícitas o implícitas para afirmar que el autor participó en la batalla de Lepanto. Ni López de Toro que ha incluido La naval en su estudio sobre los poetas de Lepanto (1950: 56-61), ni Cioranescu, que ha escrito un ensayo sobre La victoria (1952: 37-49), han podido averiguar quien era Pedro Manrique. En base a una minuciosa investigación creemos poder sostener que el Pedro Manrique autor de este poema sobre la batalla naval de Lepanto pertenecía, por línea materna, a la familia de los Manrique, siendo el segundo hijo de Juan de Santo Domingo y de Doña María Manrique de Luna y sobrino de Don García Manrique fundador del colegio Manrique donde estudió Pedro. De hecho, en la Historia de la Casa de Lara se da cuenta de su participación en la batalla de Lepanto:

“D. PEDRO MANRIQUE, que está nombrado en el testamento, y mayorazgo de sus padres, y es quien D. Garcia Manrique de Luna su tío dejó la presentación de una beca del Colegio Manrique, siguiò la milicia, y después de haber hecho muchos servicios a Felipe II, se halló en la batalla de Lepanto el año 1571 donde peleó tan valerosamente, que $\mathrm{S}$. Pio $\mathrm{V}$ le concedió jubileo plenísimo el día 7 de Octubre de cada un año para la Capilla del S. Cristo de la Trinidad de Burgos: la cual y la Capilla de N. S. del Rosario, y la escalera referida, que está en medio dellas, adornó este Caballero con los retablos, y con los bultos y armas de sus padres, y otras cosas. Y en cada una desta dos Capillas hay dos banderas que dicen los Religiosos haberlas ganado en la batalla de Lepanto. Murió D. Pedro en Portugal sirviendo a Felipe II y por no haber casado, ni tener sucesión heredó sus bienes Doña María su madre, que respecto de ser fallecido, no hace memoria dél en el testamento que otorgó en 9 de Enero de 1580. Pero Don Alonso su hermano, que le amó mucho, dispuso, cinco años después, que su herencia se gastase en las obras pías que adelante referiremos" (Salazar y Castro, 1694: 522).

Se trata de otro soldado-poeta más que versifica unos hechos de los que ha sido testigo presencial. En su obra, Luchaly, como viene nombrado en el poema, ocupa un lugar relevante entre los personajes de la escuadra otomana. Aparece por primera vez en el Canto I donde se dice que Marco Antonio esperaba con ansia la escuadra mandada por Andrea Doria (de la que Pedro Manrique formaba parte) y explica que el causante de su retraso es Luchaly: 


\begin{abstract}
"Tardamos porque entonces vino nueva
del falso Luchaly, que tan pujante navega, que veinte y ocho velas lleva más que no el viento vano y arrogante, éste es un renegado cierta prueba de que es Fortuna infiel, y aun inconstante, fue un pobre calabrés, después esclavo, a quien un bofetón dio un turco bravo.

Del remedio perdida la esperanza mirad un gran rancor adonde llega, que a trueque de entregarse en la venganza de Dios, y de su santa Fe reniega" (ff. 9v-10r).
\end{abstract}

Es significativo que las primeras palabras que Manrique dedica a Luchaly sean para calificarlo de falso, pero reconociendo al mismo tiempo su vigor de navegante aunque vano y orgulloso, cualidades que definen bien al renegado calabrés que se hace turco no por una conversión sincera sino porque habiendo recibido un bofetón no encuentra otra forma de vengarse de la ofensa recibida que la de abrazar el islamismo. La decisión tomada le llevará a hacerse rico y famoso. Y al renegar de su fe, añade, entrega su alma al diablo, se hace corsario junto a otros pobres con tan buena suerte "que vino de un esclavo y vil cosario / A verse rey de Tripol, ved su suerte /Y aun rey de Argel, a Hespaña tan contrario " (ff. 10v-1 1r).

Narra, luego, como Andrea Doria trata inútilmente de darle caza por todo el Mediterráneo, y como Luchaly no solo le hace perder su pista, sino que además consigue cobrar tributos a los nuevos reinos conquistados y apresar algunas naves cristiana entre Malta y Sicilia. Manrique de esta guerra de corso entre Andrea Doria, su comandante, y Luchaly describe minuciosamente la mutua persecución de las dos escuadras. Damos un ejemplo en el que el soldado poeta justifica la victoria de Luchaly por la superioridad numérica de sus naves:
"A quien ya Juan Andrea con pecho osado
en vano le buscó, qu' es gran astuto
en la Pantanalea desarbolado
estuvo, y en el Cymbano sin fruto,
porque en Biserta estaba el renegado 
tomando al nuevo reino su tributo.

El cual salió de allí, porque ya que espía

y en el canal de Malta se metía.

Porque estando en la guarda una galera

suya, acertó a tomar cierta fregata

que salió de Sicilia y dio manera

a Luchaly, según lo que relata

para que salga, y sale, y las espera

que su solicitud nada dilata,

la cual le dijo el punto cuando parte

el general de Malta y a que parte.

De Malta las galeras animosas

quel mar siempre sulcaron con buen viento

buscaron nuestra armada presurosas

queriendo concurrir a un mismo intento

por fin de un capitán, y ciertas cosas

a Malta van con este fundamento

desde Sicilia, y fiero las aguarda

aquese rey de Argel, con mucha guarda.

Al alba Luchaly tuvo tal tino

que al general da caza y se apresura

las nuestras no confirman el camino

que no hay para el temor parte segura.

Las dos fueron al mar y su destino

les puso entre enemigos sepultura,

la fuste capitana a tierra corre

la cuarta se amparó con una torre.

Con sus veinte y ocho velas, ved que espanto,

a cuatro acometió, mas aunque fiera

sin grande resistencia, ni quebranto

tomó a la religión las tres galeras,

presa que debe con perpetuo llanto

llorarse, pues se pierden sus banderas" (ff. 10v-1 lv). 
Luego, resalta la codicia del renegado calabrés que no descansa y aspira a cobrar siempre nuevas presas con que aumentar su riqueza y poder y así con " una codicia atroz, y una vil ira" se dirige a Grecia, luego a Candía y a otras islas, hasta llegar a Negroponte como caudillo de los corsarios (f. $12 r$ ).

El autor, como todos los que describen el combate naval de Lepanto, también detiene su mirada sobre Uchalí que con doce embarcaciones sale de Argel de donde "vienen veloces prósperas galeras / y en ellas hombres de admirable traza" (f. 287) a las que se añaden nueve de Balagi de la Velona, las trece de "aquel Carabey que es hijo astuto / del fiero Luchaly [...]" (f. 233r), las quince de Carachaly que también había sido esclavo y otras más que componen cuerno izquierdo. También Manrique dice que Luchaly evita la lucha frente a frente con Doria: "No busca al 'Oria el rey d'Argel que busca / combatir sin peligro, está a la mira / ve tanta muerte y roja luz corusca / que con sartas y galeras se retira" (f. 366r). Sin embargo, sí se enfrenta con la nave de Malta que desdichadamente sucumbe al ataque de Luchaly. Manrique no se limita a narrar los hechos sino que además expresa su dolor por la suerte de los caballeros de Malta: "De todo más que todo me lastima / de aquella religión la triste historia / del fiero calabrés que así se anima / a conseguir con ellos gloria" (f. 385v). Insiste en la fiereza del renegado y sobre todo en que acomete con ventaja pues "anduvo cauteloso que es astuto / mirando cómo a cada cual le fuese / estaba en la batalla resoluto / de se portar en ella, como viese" (f. 385v), una actitud cautelosa pero cobarde que le permitió cobrarse las banderas malteses y dar muerte a casi todos. Manrique termina su narración insistiendo en la barbarie y en la cobardía de Luchaly que, cuando se ve en peligro procura ponerse en salvo, pero reconoce "que es astuto y sagaz de ingenio agudo" (f. 395r). Además de la Crónica sobre la batalla de Lepanto, de la que antes hemos hablado, Costiol publica, como segunda parte de ésa, un poema titulado Canto al modo de Orlando de la memorable guerra entre el gran Turco Selino y la Señoría de Venecia. Con la felicísima victoria del Serenísimo Señor Don Juan de Austria, general de las armadas de la confederación Cristiana, en el que reescribe poéticamente los mismos argumentos, es decir la guerra de Chipre y la batalla de Lepanto. Como apunta el título, a imitación del Orlando de Ariosto, es un poema en octavas dividido en tres cantos que, como él mismo dice en el "Prólogo al lector", ha traducido (aquí no dice de qué lengua, pero en el epígrafe especifica que es del italiano), aunque, añade, que algunas estancias son suyas.

En el Canto Segundo en el cual se contiene la conclusión de la Sancta Liga, y la llegada del señor Don Juan de Austria a Mesina, donde se ayuntaron las armadas de la confederación, Costiol alude a como Ochialí había 
acumulado sus riquezas en la guerra de corso y a su incorporación a la armada turca junto con Caracossa:

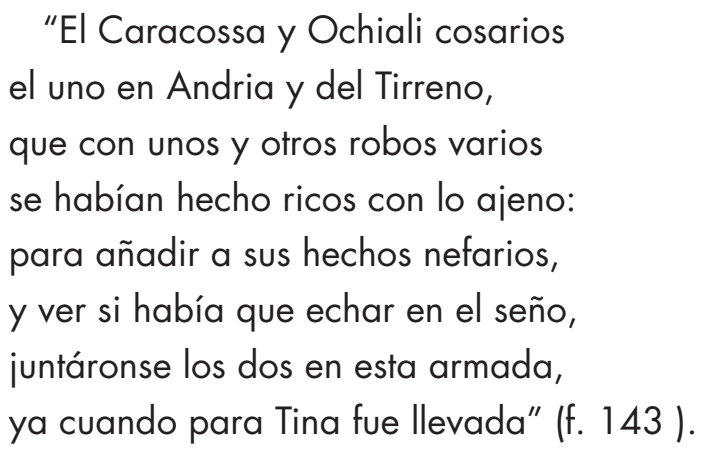

Más adelante, al narrar lo pormenores de las correrías de Ochalí antes de juntarse con la armada turca que se está preparando para la batalla contra la Liga, dice que implacable ataca las costas del Adriático, asolando y saqueando las localidades costeras, matando y haciendo numerosos cautivos:

"Ochali, Caracossa juntamente, que licencia del general tuvieron, tomando su camino diferente, después que del Dulciño se partieron: subiéronse por el oriente, a do notables males nos hicieron, sobre Liesena, y Corsula robado, todo lo que pudieron y quemando.

Después de haber su crueldad hartado, con sangre de la gente baptizada, y haber no pocos dellos captivado, y allá dejando la tierra abrusada: dallí volverse presto han acordado, para juntarse luego con l'armada, tópanse en fin con grandes alegrías jactándose de muchas valentías" (f. 157). 
En el Canto Tercero, en el cual se cuenta la batalla de las armas infiel y cristiana, y la victoria del valerosíssimo capitán don luan de Austria, Costiol describe la formación de la batalla y por lo que se refiere al puesto ocupado por Ochalí dice:

"Digo quel cuerno derecho señalaron

al cosario Sirocco, gran tirano:

con él a Mahometh Bey juntaron

otro tal como el Turco inhumano.

Al Ochalí el izquierdo encomendaron, con Caracossa de la brava mano,

y ansí venían ellos confiados,

de luego nos tragar en dos bocados" (f. 164).

Es decir, a diferencia de otros poetas, testifica solamente la presencia en la batalla del rey de Argel, sin describir ninguno de sus movimientos, ni siquiera alude a su ataque a la nave de Malta ni a su fuga cuando ve que todo está perdido.

El poeta, músico y pintor portugués Jerónimo de Corte Real, ${ }^{23}$ escribe la Espantosa y felicísima victoria (1575), ${ }^{24}$ un extenso poema sobre la batalla de Lepanto dividido en 15 cantos cada uno de los cuales está ilustrado por un grabado realizado por el mismo autor. De hecho, en el Prólogo dedicado a Felipe II, escribe que para componer sus versos se valió de "las más verdaderas informaciones, que [le] fueron posibles, tomando la substancia de aquellas que aunque de varias partes [le] fueron traídas, al fin se reducían todas a la misma opinión"; también dice que ha elegido escribir en castellano, a pesar de las críticas, avalado por sus abuelos los Mendoza y los Bazanes para que "la variedad de las colores y la invención de la pintura" a la que S. M. es inclinado "haga fácil aquel peso y molestia de una lectura falta de invención y de aquel ornamento y polido estido que en los grandes ingenios, solo se hallan". En la obra de Corte Real los elementos históricos narrados minuciosamente se mezclan con elementos propios de la épica clásica que imprimen a la narración un tono mítico.

Al final del Canto IV aparecen en el horizonte ocho sedosas velas con las que Uchalí va encontrarse con el gran Bajá quien, esa misma noche, ha

23 Sobre el autor cf.: Lopes de Almeida, 1979.

24 El manuscrito se conserva en la Biblioteca Nacional de España (Mss 3693). Hay una edición de 1578 publicada en Lisboa por António Ribeiro. 
tenido un sueño premonitorio que termina con la visión simbólica de la futura derrota turca pintada en el escudo de Don Juan de Austria. Las galeras de Ochalí con centenares de naves venidas de varias partes se concentran en Negroponto a las órdenes del gran Bajá, en espera de la batalla, pero Ochalí, que no sabe estar inactivo, se hace a la mar de nuevo donde sigue asolando los lugares costeros. Sus correrías son cantadas en el capítulo V, en el que el rey de Argel es protagonista indiscutible, como se anuncia en el epígrafe: Estando la armada turquesca en Negroponto esperando por soldados de la Morea, Ochialí rey de Argel juntándose con otras galeotas de Cossarios, van la vuelta de Candia, haciendo daño en algunos pequeños lugares: y lo mesmo hicieron al Zante y a Cefalonia, a donde dieron muerte a mucha gente, llevando otra mucha captiva. Lo primero que hace el poeta es presentar al personaje:
"No quiso el Ochialí bravo cosario pasar en ocio el tiempo, ni perderlo con sagaces cosarios va el maldito que recibió en Calabria l'agua santa del sagrado baptismo, en su primera edad, y la observancia dominica. Ay de ti Ochialí, que así trocaste la hermosura y la gracia del Olimpo por la hedionda, horrible escura cueva del tenebroso Averno y negra Estigie. Trocaste ver a Dios? A Dios trocaste por las pálidas sombras infernales trocaste gozo y gloria sempiterna por aflicción, tristeza, y amargura? Ay, ay de tu alma triste!, que rompido el mortal velo, irá do no ay consuelo, do se niega el placer, do siempre viven en tormento, en dolor, y en llanto esquivo" (Canto V, f.68r).

La presentación de Corte Real es atípica respecto a la de otros autores, pues, en línea con la estructura narrativa del poema, mezcla poéticamente los elementos reales con consideraciones personales en las que lo mitológico se entrelaza con lo religioso. Luego sigue explicando que, no queriendo 
perder el tiempo en ocio, mientras Alí Bajá reúne a los soldados de Morea y a valientes jenízaros, Ochialí sale de Negroponto con ocho galeras suyas bien provista y cuarenta y dos menores dirigiéndose con viento favorable a Corfú y Candia, donde cometen toda clase de crueldades llevando desolación y terror a las poblaciones por las que pasa. Seguro de su victoria "al primero lugar, luego al segundo, / tercero, cuarto, quinto y sexto, abrasan, / con sed rabiosa, y con furor insano / a cuantos hallan privan de la vida" (f. 68v).

Narra también el ataque a la plaza fuerte de Cataro defendida heroicamente por Matteo Bembo, y como estando allí, al recibir la noticia de que la armada mandada por Juan de Austria está en Mesina, "el sagaz Ochialí levanta el cerco, / a Cataro dejando, en cuya fuerza / halló tal resistencia, dando al viento / la blanca vela, el puerto deja libre. / La vuelta de Lepanto lleva, y llega / adonde el gran Bajá lo está esperando" (f. 77v). Pero antes de dirigirse a Lepanto el rey de Argel embarca más soldados, hasta llegar a un número de 24.000 .

En la descripción de la batalla el poeta exalta la argucia y habilidad del calabrés que no solo consigue salvarse, sino que hace estragos en las galeras de Malta hasta que viendo acabada la flota otomana que se creía invencible y considerando que si permanece en la lucha será alcanzado:
"Tomando el estandarte y seña honrada desa religión que a Malta ilustra. huye el sagaz tirano, siempre teme, y del vecino mal no se asegura, con grande turbación mil veces mira, si Cristiana galera en pos vaya.
Con riguroso azote el renegado hace doblar el remo y rasga el agua: llevando allí volando el mar y el viento con una amarillez mortal de rostro" (f. 202r).

El poeta nos deja esta última imagen de Uchalí alejándose de la batalla para no caer en manos de sus enemigos, y llevando consigo el estandarte de la nave de Malta como testimonio de la victoria conseguida sobre los caballeros de San Juan. 


\section{Uchalí en los textos dramáticos de Lope de Vega y Vélez de Guevara}

La presencia de Uchalí en el panorama teatral español del Siglo de Oro está estrechamente ligada a su protagonismo en la batalla de Lepanto, pero no en todas las obras dramáticas que ponen en escena la famosa batalla aparece la figura de Uchalí. Además de una mención que hemos encontrado en La nueva victoria del marqués de Santa Cruz de Lope de Vega en la cual Fátima, al comienzo de primera jornada, al narrar a Alí Bajà que era la nieta del general Alí muerto en la batalla de Lepanto, se refiere a Uchalí de manera despectiva, ${ }^{25}$ hay dos comedias que, desarrollando el tema de la victoria naval de la Santa Liga, incluyen entre las dramatis personae al renegado calabrés: La Santa Liga de Lope de Vega y El águila del agua de Luis Vélez de Guevara. ${ }^{26}$

En La Santa Liga, ${ }^{27}$ visto el marcado tono épico-celebrativo de la comedia, los personajes otomanos, que revisten el papel de antagonistas de los cristianos, como es obvio en una distribución maniquea de los roles, están caracterizados con los habituales estereotipos negativos. El único al que Lope confiere una connotación relativamente positiva es Uchalí. En efecto, en esta obra, al contrario de La Nueva victoria del marqués de Santa Cruz, el dramaturgo lo presenta come un musulmán valiente, hábil estratega y atento a los intereses políticos y militares del imperio otomano, y estos rasgos se evidencian a lo largo de toda la comedia.

Por ejemplo, en la segunda jornada, cuando ya había empezado la toma de Chipre por parte de los turcos, la intervención de Uchali se revela determinante para el éxito de la guerra. El renegado calabrés, habiendo sabido que a causa de la rivalidad amorosa entre los generales Mustafá y Alí, prendados ambos de Constancia, estaba en peligro la ocupación de la isla, va a Chipre y amonesta severamente a los generales censurando su conducta indigna y echándoles en cara que descuidando su deber de soldados estaban poniendo en entredicho la conquista de Nicosia que solo se podía conseguir luchando juntos contra los enemigos del imperio turco.

25 Dice Fátima: "no era tan Aquiles como Ulises / ni tan Pirro como César" (p. 186); poco después le llama cobarde: "Si como Uchalí cobarde/ mi abuelo famoso fuera,/ y volviera las espaldas/ con tan vergonzosa afrenta,/ nunca el español Don Juan / en Mesina las banderas/ de Selín vuestro señor/ arrastrara con vergüenza" (pp. 186-87). Citamos de la edición de la viuda de Pedro Verges (Parte XXV), Zaragoza, 1647.

26 Es plausible pensar que en la desaparecida Batalla naval que Cervantes menciona entre sus obras teatrales en la "Adjunta" al Viaje al Parnaso y en el "Prólogo" a Ocho comedias, uno de los personajes fuese el "tiñoso calabrés", como lo define el autor en el Quijote.

27 Citamos de la edición de la viuda de Alonso Martín, Madrid, 1621. 
Dice Uchalí: "No estuviera Nicosia / en pie si junta estuviera / vuestra heroica valentía / ni aquí Venecia pudiera / socorrella cada día (ff. 106r-106v). Pero no le resultó muy fácil al rey de Argel convencerlos para que abandonaran la contienda amorosa y se dedicaran a combatir a sus enemigos, los cristianos. Solo después de una larga y animada discusión en la que resulta claro que Costanza no quiere a ninguno de los dos, y de la decisión de Uchalí de devolver la esclava a su marido (el capitán Leonardo defensor de Famagusta), consigue que Alí y Mustafá sellen la paz y tomen la isla.

Otro episodio significativo que pone en evidencia la prudencia del estratega Uchalí, es cuando, en la ultima jornada, ya constituida la Santa Liga, Mustafa, Alí y Uchalí se reúnen para discutir sobre la utilidad de entrar en guerra contra la armada naval cristiana. El calabrés, valorando prudentemente las fuerzas adversarias, considera más conveniente volver a Constantinopla victoriosos y con un botín de "quince mil vidas prisioneras" que afrontar la armada cristiana $y$, sabiamente, aconseja a los generales que no subestimen la potencia naval de la coalición cristiana: "ni aquí solo se embarcan españoles; / el gobierno de cuerdos venecianos / a sus galeras sirve de faroles, / franceses, genoveses y romanos, / con los de Malta, en la milicia soles, /vienen juntos aquí, mirad que os digo, / que el sabio no desprecia al enemigo" (ff. 126r-136v). Alí interpreta las palabras de Uchalí como un acto de cobardía y pusilanimidad de quien, a pesar de ser superior en número, teme al adversario, y pregunta retóricamente: " ¿Volveremos, por dicha, las espaldas / al cristiano don Juan, mozo orgulloso, / como mujeres de cobardes faldas? (f. -136v). Mustafá, en cambio, pone en duda su auténtica conversión al islamismo y considera que su actitud está dictada porque, como tantos otros renegados, en lo íntimo de su alma continúa siendo cristiano, por eso dice a Alí: "Alí, como Uchalí cristiano ha sido, / aún debe de tener cristiana el alma; / vuelve por el cristiano, que vencido, / él mismo ofrece la victoria y palma. (f. 136v). Ante la actitud despectiva de los generales, que incluso le dicen que si no quiere combatir se vaya con su escuadra, Uchalí reacciona con fuerza reafirmando su fidelidad al sultán y asegurándoles que participará en la batalla.

En la última parte de la obra, para dramatizar la batalla naval, Lope introduce tres figuras alegóricas, España, Roma y Venecia, que van narrando en ticoscopia las diversas fases. Y es precisamente a Uchalí, entre los generales otomanos, a quien dedican mayor espacio: España reproduce la arenga que el rey de Argel hace a sus jenízaros; Roma describe el choque entre Uchalí y la galera de Malta, y luego Venecia informa de cómo, al darse cuenta de la victoria cristiana, sale huyendo y toma puerto en la playa. Después sale a escena Uchali maldiciendo su suerte y diciendo que 
con razón temió la fuerza cristiana y que Alí, por no haberle creído, tiene ahora su cabeza en una pica. Y termina su actuación imprecando contra Mahoma y ordenando a sus hombres que pongan ruta a su reino de Argel:
"A pesar de Mahoma, ¿̇con qué cara
en la del Gran Señor pareceremos?
Diremos que a Filipo el cielo ampara
o que Pio Quinto es santo le diremos.
Hasta la tierra aquí se vende cara;
largad las velas y moved los remos,
llevadme a Argel, reniego de Mahoma,
o a Meca, porque allí sus huesos coma" (f. 117r).

Palabras que dejan muchos puntos interrogativos sobre el sentido que Lope quiere dar, sobre todo considerando que antes Alí ha insinuado una posible conversión solo exterior del renegado, y que ahora, ante la derrota otomana, el propio Uchalí reconoce que los cristianos han contado con la ayuda divina mientras que a los mahometanos no les ha sucedido lo mismo.

En El águila del agua de Vélez de Guevara, ${ }^{28}$ aunque Uchalí tiene un papel secundario, pues interviene solo en la última jornada y recita solo unos sesenta versos, sin embargo su función es indispensable en la economía de la obra, ya que es el único general otomano que actúa en la comedia. En efecto, manipulando la historia, el dramaturgo lo hace intervenir en las tablas no como personaje que se sitúa en el plano de la realidad histórica representada, es decir, comandante del ala derecha turca opuesta a la izquierda de la escuadra cristiana, sino como el comandante de la "real del Gran Turco", configurándolo así come el directo contrincante de Don Juan.

El hecho de que Vélez haya elegido a Uchalí como el único representante de los comandantes de la escuadra otomana, quizá se pueda explicar por el reflejo de la fama que adquirió después de la batalla naval, a la que seguramente contribuyó el retrato que Cervantes hizo de él en el Quijote ${ }^{29}$ y que se difundió por toda España. Por lo tanto, era un personaje fácilmen-

28 Citamos de la edición de MANSON William R. y PEALE George (2003).

29 Vélez hace varias alusiones a la obra cervantina e incluso la cita directamente, por ejemplo, cuando Escamilla dice que un galeote se pasa la mayor parte del tiempo leyendo y Almendruca responde: "Don Quijote es de la Mancha". 
te reconocible y que el público teatral asociaría, sin duda, como el turco más valeroso que los cristianos tuvieron como antagonista en la batalla de Lepanto.

Como hemos dicho, Uchalí entra en escena en el último acto cuya acción transcurre casi toda en la galera Real española capitaneada por don Juan de Austria. Antes de entablar la batalla el hampón Escamilla, que había sido condenado por la justicia a servir en la galera Real por asesino, en un largo parlamento cuenta a los otros condenados y a su daifa Almendru$\mathrm{ca}$, los hechos que han llevado al gran enfrentamiento naval y concluye diciendo que trecientas galeras turcas están llegando a Lepanto y que los generales que han sido nombrados para esta hazaña son "Luch Alí, Pi Alí y Siroco / tres galgos de buena casta" (vv. 2964-65, p. 206). Al acabar su discurso, suena un pito, señal que don Juan está embarcado en la Real, y todos se preparan para tomar los remos.

Nada más zarpar la galera de don Juan, entra en escena Uchalí "turco y con bengala" que sobre la popa de su galera dirige una arenga a sus soldados. El largo parlamento, único discurso que Vélez pone en boca de Uchalí, sirve al dramaturgo para caracterizar negativamente al personaje definiéndolo con claridad como enemigo de los españoles y de la Cristiandad. En esta larga secuencia de silvas pareadas, haciendo recurso a juegos metafóricos, referencias mitológicas, cultismos, Uchalí incita a sus "jenízaros valientes" exhortándolos:

$$
\begin{aligned}
& \text { "a castigar la armada del Poniente } \\
& \text { y su pretexto loco } \\
& \text { con Luch Alí Baiá, Pi Alí y Siroco, } \\
& \text { vuestros tres generales, } \\
& \text { del sol antorchas y de Alá fanales, } \\
& \text { y contra los que engaña } \\
& \text { esta vil liga de Venecia, España, } \\
& \text { y el alfaquí de Roma" (vv.3164- 3171). }
\end{aligned}
$$

Pero, sobre todo, los anima a terminar con la arrogancia de don Juan, destruyendo su armada para que así "queden de tan soberbia loca armada / las glorias españolas / por navales despojos de las olas" (vv. 3206-3208, p. 214).

Y la comedia acaba con una escena cómica protagonizada por los dos graciosos: el hampón Escamilla llevando estandarte turco en la boca y los 
dos hijos del Bajá debajo de los brazos y Almendruca con un medio remo diciendo a don Juan: "¡Aténgome a Pero Vázquez / de Escamilla, de gloriosa / memoria, y al medio remo / con que he espantado las moscas / a Luch Alí!" (vv.3607-6611). Al final, queda patente que Vélez a través de las palabras de Almendruca ridiculiza y degrada a Uchalí, convirtiendo al famoso renegado calabrés, al enemigo per antonomasia de los españoles, en un personaje risible.

\section{CONCLUSIÓN}

Después de este breve recorrido sobre la figura histórica de Uchalí y por la imagen que de él nos presentan los cronistas y poetas coevos y los dramaturgos de la primera mitad del siglo XVII, podemos decir que, a pesar de las distintas opiniones e interpretaciones que los autores hacen de este legendario personaje, que de esclavo llegó a ser uno de los corsarios más temidos y respetados en todo el Mediterráneo, no hay duda de que en general se le considera un gran estratega y como uno de los hombres más singulares de su tiempo. Es el paradigma del renegado, que no se resigna a su mísera suerte de esclavo y elige el único camino que encuentra primero para salvar su vida y luego para medrar. Pero esta elección hace que en un mundo fronterizo y maniqueo, para unos sea un héroe digno de admiración mientras que para otros sea un hombre despreciable y cruel. Pero lo que es innegable es que sus gestas se propagan por todo el Mediterráneo convirtiéndose ya en vida en un ser legendario cantado o denigrado por cronistas y poetas.

Su fama llegó a ser tal que hasta el mismo rey de España se preocupa de seguir sus movimientos y se crea en torno a él una red de espionaje; como hemos podido verificar en los numerosos documentos conservados en el Archivo de Simancas, el monarca español está muy bien informado sobre todo lo relacionado con el rey de Argel, prueba de ello es la correspondencia que intercambia, directa o indirectamente, con el duque de Medinaceli, el marqués de Pescara, Andrea Doria, Alonso de la Cueva, Alonso Pimentel y otros personajes notables, ${ }^{30}$ sobre todo a partir del momento en que algunos esclavos se amotinan contra Uchalí en 1562 y tratan de matarlo sin conseguirlo. Los documentos de Simancas también dan prueba de los intentos, después de la batalla de Lepanto, por conseguir que el renegado calabrés volviera a la religión cristiana y se pusiera al servicio del rey. Una serie de cartas, algunas de ellas cifradas, de don Juan de Austria fechadas en Mesina entre el 20 y 21 de 1571 son clara prueba de ello. 
El intermediario era el capitán Pedro Pablo de Arcuri que había sido renegado muchos años y que era amigo de Uchalí, al cual el héroe de Lepanto da instrucciones escritas para cumplir su cometido. Las instrucciones son que le recuerde que fue cristiano y que procure aprovechar la ocasión que se le ofrece de volver a su tierra y familia muy honrado y que él le ofrece en nombre del rey grandes mercedes "y que él puede pedir las que más le contentaren, y dexar sobre mi palabra el cumplimento de lo que se le prometerá, aunque si quisiere algún género de dignidad que se le pueda dar también se le dará, a su contentamiento". ${ }^{31}$ El servicio que pide don Juan a cambio es: o que encuentre la forma de dar al rey, Argel y Tripoli, o alzarse con una banda de bajeles turcos $O$, en altarnativa, dar alguna plaza importante. Pero nada de esto sucede, Uchalí sigue hasta el final de su vida fiel al sultán.

\section{BIBLIOGRAFÍA}

ALVES, Helio J. S. (1998), Jerónimo Corte-Real, Poesia, Angelus Novus Editora, Braga-Coimbra.

CAMAMIS, George (1977), Estudios sobre el cautiverio en el Siglo de Oro, Gredos, Madrid.

CERVANTES, Miguel de (1987), El ingenioso hidalgo Don Quijote de la Mancha, Gredos, Madrid.

CERVANTES, Miguel de (2019), Información de Argel, ed. Sáez Adrián, Catedra, Madrid.

CIORANESCU, Alexandre (1952), "Un poème inconnu de Don Pedro Manrique", Mélanges Mario Roques, París, pp. 37-49.

CORTE REAL, Jerónimo (1575), Espantosa y felicissima victoria concedida del cielo al señor don Juan de Austria en el golfo de Lepanto de la poderosa armada othomana, en el año de nuestra salvación de 1572 (sic), compuesta por leronimo Corte-Real cauallero Portugués, año de mil y quinientos $L X X V$.

COSTIOL, Hierónimo (1572), Primera Parte de la Chrónica del muy poderoso Príncipe don luan de Austria hijo del Emperador Carlo quinto. De las jornadas contra el gran Turco Selimo Il començada en la pérdida del reyno de Chipre: tratando primero de genealogía de la casa Ottomana. Dirigido al Illustrissi. y Excellentis. Señor Don Hernando de Toledo, Prior de Castilla Visorey, y Lugarteniente de su Magestad en el Principado de Cataluña, y de su Consejo supremo, etc. Copiada por Hierónymo de Costiol, Viuda de Bartolomé de Nágera, Zaragoza. 
DAVIS, Robert (2004), Christian slaves, muslin masters: white slavery in the Mediterranean, the Barbary Coast, and Italy, 1500-1800, Palgrave Macmillan, Londres.

EISENBERG, Daniel (1996), "Cervantes, autor de la Topografía e historia general de Argel publicada por Diego de Haedo", Cervantes: Bulletin of the Cervantes Society of America, vol. 16.1, pp. 32-53.

HAEDO, Fray Diego de (1612), Topographía e Historia general de Argel, repartida en cinco tratados do se verán casos estraños, muertes espantosas, y tormentos exquisitos, que conviene se entiendan en la Christiandad: con mucha doctrina, y elegancia curiosa dirigida al Ilustríssimo señor Don Diego de Haedo Arzobispo de Palermo, Presidente, y Capitán General del Reyno de Sicilia, Diego Fernández de Córdoua y Ouiedo Impressor, Valladolid. HERRERA, Fernando (1572), Relación de la guerra de Cipre, y suceso de la batalla naval de Lepanto, escrita por Fernando de Herrera; dirigido al llustrísimo y Ecelentísimo Señor Don Alonso Pérez de Guzmán El Bueno, duque de Median Sidonia, y conde de Niebla, Alonso Escrivano Impressor, Sevilla. KAISER, Wolfgang (2006), "Frictions profitables. L'économie de la rançon en Méditerranée occidental XVle-XVIlle siècles", en CAVACIOCCHI, Simonetta (ed.), Ricchezza del mare, ricchezza dal mare. Secc. XIII-XVIII, Le Monnier, Florencia, vol. II, pp. 689-701.

KAISER, Wolfgang (2008), Le commerce des captifs: les intermédiaires dans l'echange des prisonniers en Mediterranée, XVe-XVIIle siècles, École Française de Roma, Roma.

LOPES DE ALMEIDA, Manuel (1979), Obras de Jerónimo Corte Real. Sucesso do segundo cerco de Diu. Náufragio de Sepúlveda. Auto dos quatro novissimos do homem. Elegias, Lello \& Irmão Editores, Oporto.

LÓPEZ DE TORO, José (1950), Los poetas de Lepanto, Instituto Histórico de Marina, Madrid.

MANRIQUE, Pedro (s.a.), La naval, Ms. 3942, BNE.

MARTINI, Gian Giacomo (1635), Consiliorum sive responsorum iuris D. loan. lacobi Martini I. C. Calabri a Sancto Nicolao a lunca, et eiusdem Ecclesiae Maioris Abb. Curati. Volumen Primum. Opus omnibus V. I. peritis, tam in Pontificio, quam Cesareo lure versantibus apprime necessarium, et utile, et bonarium artium, politicae, et Historiarum amatoribus non iniucundum, cum argumentis, et indice omnium rerum, et sententiarum locupletissimo, Alphabetico ordine digesto, Sancti Nicolai, Apud Joannem Baptistam Russo, et Dominicum lezzo.

MARTIRE, Domenico (1887), Calabria sacra e profana, Tip.Migliaccio, Cosenza. 
SALAZAR Y CASTRO, Luis de (1694), Pruebas de la historia de la Casa de Lara sacadas de los instrumentos de diversas iglesias y monasterios, de los archivos de sus mismos descendientes, de diferentes pleitos que entre sí han seguido y de los escritores de mayor crédito y puntualidad, Imprenta Real, Madrid.

SOLA, Emilio (1991), "Antonio de Sosa: Un clásico inédito amigo de Cervantes", Actas del I Congreso Internacional de la Asociación de Cervantistas, Anthropos, Barcelona, pp. 409-412.

SOLA, Emilio (2010), Uchalí. El calabrés Tiñoso, o el mito del corsario muladí en la frontera, Ediciones Bellaterra, Barcelona.

TETI, Vito (2009), "Gian Giacomo Martini e Uluccialì alias Kiliç Alì Pasha: aspetti della costruzione dell'identità calabrese tra XVI e XVII secolo", en ANSELMI, Alessandra (ed.), La Calabria del Viceregno Spagnolo. Storia arte architettura, Gangemi Editore, Roma, pp. 139-169.

VALENTE, Gustavo (1973), Calabria Calabresi e Turcheschi nei secoli della pirateria (1400-1800), Framas's, Chiaravalle Centrale, p. 134.

VALENTE, Gustavo (1960), La vita di Occhiali. Da schiavo a Re di Tunisi, Tripoli e Algeri, Editrice Ceschina, Milano-Varese.

VATIN, Nicolas (2001), Les ottomans et l'occident (XVe-XVle siècles), Isis, Estambul.

VEGA, Lope de (1621), La Santa Liga, Viuda de Alonso Martín, Madrid.

VEGA, Lope de (1647), La nueva victoria del Marqués de Santa Cruz, Viuda de Pedro Vergés, Zaragoza.

VELEZ DE GUEVARA, Luis (2003), El águila del agua, Juan de la Cuesta, Delaware. 


\title{
EL TRIPLE ASCENSO DE PIETRO VELASCO. CAUTIVERIO, PROMOCIÓN DEL TALENTO Y "ASIMILACIÓN ANTAGONISTA" ENTRE CRISTIANDAD E ISLAM (1583-1608)
}

\section{THE TRIPLE RISE OF PIETRO VELASCO. CAPTIVITY, TALENT PROMOTION AND "ANTAGONISTIC ASSIMILATION" BETWEEN CHRISTENDOM AND ISLAM (1583-1608)}

\author{
Valentina Oldrati \\ Universidad Autónoma de Madrid
}

\begin{abstract}
RESUMEN
El objetivo de este ensayo es analizar la promoción del talento como medio de salida desde una condición de cautiverio o esclavitud en el contexto de la llamada rivalidad Habsburgo-otomana. Para ello, se analizará el caso de Pedro Velasco, un ex-cautivo dominicano que tras renegar entró a formar parte del séquito y de la armada del Kapudan Pachá Scipione Cicala, para luego volver al catolicismo y pasar al servicio de Florencia primero, y de España después (1590-1608 ca).
\end{abstract}

A través de este caso, se reflexionará sobre el vínculo que se creó en el siglo XVI entre conversión religiosa y posibilidad de ascenso socio-económico, evidenciando como, en numerosas ocasiones, fueron las grandes rivalidades internacionales y los equilibrios geopolíticos a permitir y orientar las carreras de los (ex) cautivos más audaces y calificado

Palabras clave: Renegados, cautiverio, espionaje, Gran Ducado de Toscana, Monarquía Hispánica, Imperio Otomano.

\begin{abstract}
The arrival of the colonizers on the Caribbean islands was a milestone in history. It influenced the way we perceive the world today. The way the island of San Juan Bautista (Puerto Rico) was colonized helps to understand how the production system was modified, with a large part in the slave work. One of the ways of perceiving it is the analysis of the different archival sources that mention which people were in charge of doing this work. One of the most important families being that of Ponce de León who together with other personalities supported a slavery model, whose footprint, even today,
\end{abstract}

Keywords: Renegades, captivity, espionage, Grand Duchy of Tuscany, Spanish Monarchy, Ottoman Empire. 


\section{RESUM}

\section{EL TRIPLE ASCENS DE PIETRO VELASCO. CAPTIVITAT, PROMOCIÓ DEL TALENT I "ASSIMILACIÓ ANTAGONISTA" ENTRE CRISTIANDAT I ISLAM (1583-1608)}

L'objectiu d'aquest assaig és analitzar la promoció del talent com via de fuita des d'una condició de captiveri o esclavitud en el context de l'anomenada rivalitat Habsburg-otomana. Per aquesta raó, s'analitzarà el cas de Pedro Velasco, un excaptiu dominicà que després de renegar va entrar a formar part del seguici i de l'armada del Kapudan Pachá Scipione Cicala, per a seguidament tornar al catolicisme i passar al servici de Florència primer, i d'Espanya després (ca. 1590-1608). Mitjançant aquest cas, es reflexionà al voltant del vincle que es va crear al segle XVI entre la conversió religiosa i la possibilitat $d^{\prime}$ 'ascens socioeconòmic, evidenciant com, en nombroses ocasions, van ser les grans rivalitats internacionals i els equilibris geopolítics els que van permetre i orientar les carreres dels (ex)captius més audaços i qualificats.

Paraules clau: Renegats, captiveri, espionatge, Gran Ducat de Toscana, Monarquia Hispànica, Imperi Otomà. 


\section{INTRODUCCIÓN}

El objetivo de este ensayo es analizar la promoción del talento como medio de salida desde una condición de esclavitud o desventaja en el contexto de la llamada rivalidad Habsburgo-otomana. Se examinarán así las trayectorias de vida trans-religiosas y trans-imperiales que esta rivalidad involuntariamente generó. ${ }^{1}$

Concretamente, se analizará el caso de Pietro Velasco, un cautivo de origen calabrés que tras renegar entró a formar parte del séquito y de la armada del Kapudan Pasha otomano Cigalazade Yusuf Sinan Pasha, ${ }^{2}$ también renegado, para luego volver al catolicismo y pasar al servicio de Florencia primero, y de España después. A través de los periplos de Velasco se reflexionará sobre el vínculo que se creó en el siglo XVI entre conversión religiosa y posibilidad de ascenso socio-económico, evidenciando como, en numerosas ocasiones, fueron las grandes rivalidades internacionales y los equilibrios geopolíticos a permitir y orientar las carreras de los cautivos y ex-cautivos más audaces y calificados.

En este contexto, nos serviremos del concepto de talento no solamente para indicar aquellas capacidades innatas que una persona tiene para aprender o desarrollar con habilidad una actividad determinada, sino también para señalar todas aquellas competencias que el ser humano puede adquirir a través de la experiencia. En nuestro caso, al margen de las mencionadas (y difícilmente verificables) aptitudes innatas, nos referimos a los conocimien-

1 Debemos a Natalie Rothman la introducción de esta categoría en la historiografía del Mediterráno moderno. ROTHMAN, E. Natalie (2012), Brokering Empire: Trans-Imperial Subjects between Venice and Istanbul, Cornell University Press, Ithaca. 
tos lingüísticos que Pietro Velasco adquirió viviendo entre las dos orillas del Mediterráneo y, más aún, a las competencias de tipo naval y militar que este obtuvo navegando bajo distintos patrones.

\section{Cautiverio, conversiones Y promoción del talento}

El reinado de Felipe II es una etapa crucial para el estudio de las relaciones entre España y el Imperio Otomano. En el Mediterráneo, la expansión otomana posterior a la caída de Constantinopla agudiza enormemente y en el espacio de pocas décadas las necesidades europeas de conocer los movimientos y las intenciones del enemigo. Especialmente involucrada en la guerra contra el Turco, la Monarquía Hispánica es una de las primeras potencias católicas en crear una red de agentes y espías operativo en tierras otomano-berberiscas. ${ }^{3}$

A partir de los años treinta del siglo XVI -época de la conquista española del Peñón de Argel (1529) y culmen de la consolidación otomana en el Norte de África-y, más aún, tras las derrotas de Mostaganem (1558) y de los Gelves (1560) - es decir, tras la llegada a Estambul de un gran número de prisioneros españoles e italianos, y la consecuente puesta en marcha de las operaciones necesarias para su rescate - los Austrias de España empiezan a invertir recursos crecientes en la infiltración de espías en los centros neurálgicos más destacados del Imperio otomano.

Su labor, de lo más heterogénea, varía desde la recogida de informaciones sobre el estado de la armada turca, a la orquestación de sabotajes (in primis, la quema del Arsenal), hasta la instigación de revueltas entre cuer-

2 El título de Kapudan Pasha corresponde grosso modo al de Capitán General de la Mar.

3 La importancia de los servicios de inteligencia en la España moderna ha sido infravalorada durante largo tiempo por la historiografía tradicional, más interesada al estudio de la diplomacia oficial, sobre todo en su vertiente bélica. A partir de los años ochenta, un número cada vez mayor de historiadores - recordamos ante todo a Emilio Sola, Carlos Carnicer García, Javier Marcos Rivas, Diego Navarro Bonilla, Rafael Vargas Hidalgo, María José Rodríguez-Salgado y Enrique García Hernán - ha empezado a romper el silencio, dando por primera vez un rostro a los hombres y al funcionamiento de los servicios de inteligencia de la Monarquía Habsburgo. La relación con el Imperio otomano, clave para la gran mayoría de los autores citados, ha llamado recientemente la atención de una nueva generación de historiadores turcos, que gracias a sus conocimientos lingüísticos han empezado a integrar las fuentes otomanas con las fuentes europeas, abriendo las puertas a unas nuevas y estimulantes fronteras de investigación. Entre ellos, señalamos primeramente a Emrah Safah Gürkan, experto de las relaciones entre Otomanes y Habsburgo en el siglo XVI. Asimismo, aunque más enfocados a las relaciones entre Turquía y Francia, señalamos los trabajos de Güneş Işıksel. 
pos sociales tradicionalmente vistos como inestables, como por ejemplo los jenízaros o los cautivos de rescate. ${ }^{4}$

Junto con la infiltración de agentes en tierras enemigas, la Monarquía hispánica desarrolla también cierta propensión hacia la acogida de aquellos desertores que estén dispuestos a ofrecer información y servicios encaminados a la derrota del Gran Turco. Si bien la eficacia de un buen espía estaba supeditada a su ubicación, siempre es posible sacar provecho de un arráez bien formado, que sepa dónde y cuándo atacar para hacer el mayor daño posible.

Los llamados "renegados" -variado colectivo humano formado por aquellos cristianos que, tras llegar a tierras islámicas, se convierten y reconstruyen sus vidas bajo la Media Luna- terminan siendo una pieza clave en este juego de traiciones dobles y triples. ${ }^{5}$ Especialmente dentro del Imperio otomano, donde es posible una cierta movilidad social de tipo meritocrático, algunos renegados alcanzan un éxito personal y profesional que les lleva a ocupar altos cargos políticos, militares y administrativos. Frecuentemente, se trata de ex-cautivos cristianos nunca rescatados que se han convertido al islam para adquirir la libertad.

4 Referencia absoluta son los estudios de Emilio Sola. En particular: SOLA, Emilio (2005), Los que van y los que vienen: información y fronteras en el Mediterráneo clásico del siglo XVI, Universidad de Alcalá, Alcalá de Henares. Mucho material, incluso fuentes de archivo, ha sido también publicado en el web www.archivodelafrontera.com. Más recientemente, Gennaro Varriale ha publicado su tesis doctoral, un instrumento muy útil para el estudio de los servicios de información hispano, con especial énfasis en el papel de Nápoles: VARRIALE, Gennaro (2014), Arrivano li Turchi: guerra navale e spionaggio nel Mediterraneo (1532-1582), Città del Silenzio, Novi Ligure.

5 Lecturas recomendadas sobre los cristianos renegados en la época moderna: GRAF, Tobias (2017), The Sultan's Renegades: Christian-European Converts to Islam and the Making of the Ottoman Elite, Oxford University Press, Oxford; KRSTIC, Tijana (2011), Contested Conversions to Islam: narratives of Religious Change in the Early Modern Ottoman Empire, Stanford University Press, Stanford; FIUME, Giovanna (2010), Schiavitù mediterranee: corsari, rinnegati e santi di età moderna, Mondadori, Milán; SIEBENHÜNER, Kim (2008), "Conversion, mobility and the Roman Inquisition in Italy Around 1600", Past \& Present, , n 200-1, pp. 5-35; MESSANA, Maria Sofia (2007), "La 'resistenza' musulmana e i 'martiri' dell'islam: moriscos, schiavi e cristiani rinnegati di fronte all'Inquisizione spagnola di Sicilia", Quaderni storici, n 42-126, pp. 743-772; GARCÍA-ARENAL, Mercedes (2001), Conversions islamiques: identités religieuses en islam méditerranéen, Maisonneuve et Larose, París; SCARAFFIA, Lucetta (1993), Rinnegati: per una storia dell'identità occidentale, Laterza, Roma; GONZALEZ-RAYMOND, Anita (1989), La Croix et le Croissant: les inquisiteurs des îles face à l'islam, 1550-1700, Centre national de la recherche scientifique, París; BENNASSAR, Bartolomé (1989), Los cristianos de Alá: la fascinante aventura de los renegados, Nerea, Madrid; y ROSTAGNO, Lucia (1983), Mi faccio turco: esperienze ed immagini dell'islam nell'Italia moderna, Istituto per l'Oriente C.A. Nallino, Roma. 
Las "élites renegadas" llaman la atención de los servicios de inteligencia de prácticamente todos los países cristianos del Mediterráneo, que consideran a los musulmanes nuevos algo más fáciles de reclutar que los moros de nacimiento, por una serie de razones que van desde su supuesta propensión a la traición, ${ }^{6}$ hasta la posibilidad de aprovecharse de los vínculos lingüísticos y familiares que muchos apóstatas conservaban con sus tierras natales. $^{7}$

Para poder entender cómo nuestro discurso quiere destacar el vínculo que une cautiverio, apostasía y promoción del talento, es necesario que abramos un paréntesis. Las órdenes y las cofradías religiosas que en los siglos $\mathrm{XVI}$ y XVII se dedican al rescate de cautivos cristianos, no rescatan a los cristianos de Alá. ${ }^{8}$ En esta óptica, para los musulmanes que comercian con seres humanos la conversión al islam de todo cautivo de rescate supondría un daño económico a evitar a toda costa. No es totalmente falso, pero existen estrategias comerciales alternativas a la venta de los cautivos.

Concretamente, los cautivos pueden ponerse de acuerdo con sus patrones para obtener el permiso para marcharse y recolectar autónomamente el dinero necesario para autorescatarse. Este mecanismo, llamado manumisión, beneficia al corso y a la piratería porque la navegación es una excelente manera para acumular rápidamente la suma necesaria para un rescate. ${ }^{9}$ Paralelamente la manumisión resulta ser una operación ventajosa para los mercaderes de esclavos, ya que no interrumpe las relaciones entre dueños y cautivos, sino que transforma su naturaleza generando un vínculo de patronazgo que establece obligaciones jurídicas y económicas para ambos contratistas.

6 Sobre la cuestión de la propensión a la traición: BUNES, Miguel Angel de (1989), La imagen de los musulmanes y del Norte de África en la España de los siglos XVI y XVII, CSIC, Madrid, pp. 232-236.

7 Sobre el mantenimiento de dichos vínculos: GRAF, Tobias (2014), "Of half-lives and double-lives: 'Renegades' in the Ottoman Empire and Their Pre-Conversion Ties, ca. 1580-1610", en FIRGES, Pascal et al. (eds.), Well-connected domains, Brill, Leiden, pp. 131-149; y KUNT, Metin Ibrahim (1974), "Ethnic-Regional (cins) Solidarity in the Seventeenth-Century Ottoman Establishment", International Journal of Middle East Studies, n 5-3, pp. 233-239.

8 Otra cosa son los rescates privados, que no están vinculados a estatutos de naturaleza religiosa.

9 La piratería es peligrosa y no es un trabajo para todos. Muchos prefieren volver a su tierra natal. Los que vuelven a España y apelan al rey para obtener una limosna correspondiente a la deuda contraída se conocen como cortados. Sin embargo, no todos intentan devolver la suma pactada, y no faltan los ex-cautivos cristianos que cuestionan la legitimidad de un contrato estipulado con un infiel. 
Por añadidura, la manumisión permite hacer la voluntad de Alá: la liberación de un cautivo se acompaña siempre a su conversión porque sólo un musulmán puede acceder ese estado de semi-libertad que le permitirá trabajar y pagar por su rescate. ${ }^{10}$ En este sentido estamos ante una audaz forma de inversión, que apuesta en el paso del tiempo y, sobre todo, en las capacidades de los cautivos antes que en una recompensa inmediata. Los renegados que llegan al islam por este camino aportan fuerza al mundo que les asimila quitando otras tantas al mundo que dejan atrás.

Dando un paso más allá en nuestro razonamiento, este mismo discurso puede aplicarse también a las numerosas negociaciones con renegados -eso sí, de alto rango- ${ }^{11}$ que los servicios de inteligencia de la Monarquía hispánica llevan a cabo entre la segunda mitad del siglo XVI y las primeras décadas de la centuria siguiente. Asimismo, y al margen de toda cuestión religiosa, las rivalidades entre potencias cristianas duplicarán estas estrategias de asimilación también en suelo europeo.

Gracias a los periplos de Pietro Velasco veremos entrar en acción a todos estos mecanismos, y reflexionaremos sobre las turbulentas relaciones que los Habsburgo de España tuvieron, entre otras potencias, con el Imperio otomano.

\section{Pietro Velasco: un dominico renegado en la armada del Gran Turco}

Pietro Velasco vivió por lo menos cuatro vidas: la primera, su infancia y juventud, en el Reino de Nápoles; la segunda, como cautivo cristiano en poder de moros; la tercera, como renegado y marinero al servicio del Gran Turco; y la cuarta, como renegado arrepentido al servicio de la "causa cristiana", entre Toscana y España. ${ }^{12}$

Aunque no sepamos casi nada de los años juveniles de este renegado, es importante señalar que aparte de cristiano bautizado - condición necesa-

10 LEWIS, Bernard (1990), Race and Slavery in the Middle East: an Historical Enquiry, Oxford University Press, Nueva York, p. 6; y GORDON, Murray (1987), L'Esclavage dans le monde arabe: Vlle-XXe siècle, Robert Laffont, París, p. 39.

11 Evidentemente, para cada historia de integración y deslumbrante éxito, existen miles de historias más discretas, trayectorias vitales destinadas a dejar huellas menos profundas en los archivos del espionaje europeo. No lo estamos olvidando, pero asumir la perspectiva de la Monarquía Hispana significa, en este caso, dirigir nuestra atención a aquellos musulmanes nuevos que han alcanzado el éxito y el poder necesarios para que Madrid llegue a considerarles como interlocutores ventajosos.

12 La presente reconstrucción biográfica recoge fuentes documentales procedentes de distintos archivos, siendo los más destacados el Archivo General de Simancas (sección Estado-Génova) y el Archivio Segreto Vaticano (Fondo Borghese). 
ria para que un renegado sea tal, especialmente desde el punto de vista inquisitorial - antes de apostatar Velasco es también un hombre de religión a todos los efectos, tonsurado en Nápoles por la Orden de Santo Domingo. En el umbral del siglo XVI, las conversiones de hombres religiosos a la fe islámica son una cuestión tan frecuente como polémica, como bien evidencia el caso Pedro Pacheco, hijo del virrey siciliano Villena y contemporáneo de Velasco, que en 1609 reniega junto con su secretario causando un escándalo que hasta llama la atención de Paolo Sarpi. ${ }^{13}$ Efectivamente, las apostasías protagonizadas por miembros del clero tienen implicaciones muy problemáticas desde varios puntos de vista. Para limitar el escándalo causado por estas particulares abjuraciones, se opta frecuentemente para un trato especialmente misericordioso - siendo en este sentido muy paradigmático el caso del joven Pacheco - y se facilita enormemente la rehabilitación de los clérigos perdidos, que a menudo hasta recuperan el hábito religioso tras abjurar del error cometido en tierra de moros. Como veremos, este será también el caso de Pietro Velasco, amparado en su retractación por un patrón tan potente como interesado en agilizar su reinserción social en tierras cristianas.

La segunda vida de Velasco empieza alrededor de 1583, cuando este se ve, en circunstancias poco claras, "cautivado de moros» y llevado forzosamente a Turquía. ${ }^{14}$ Ahí, probablemente tras un tiempo a la espera de un rescate que no termina de llegar, Velasco se convierte a la religión islámica y empieza a dedicarse al oficio de marinero y corsario.

$\mathrm{Si}$ bien nuestras fuentes son poco elocuentes con respecto a los arranques de la carrera pirática de Velasco, lo que sí nos transmiten con gran claridad es que la inserción de este cautivo en el mundo turco-berberisco es muy exitosa, tanto a nivel personal y social (en Turquía Velasco se casa y tiene hijos), ${ }^{15}$ como a nivel económico y profesional.

13 En una carta para Francesco Priuli, embajador veneciano en Praga, Sarpi se declara muy sorprendido porque los beneficios eclesiásticos que corresponden al joven Pacheco no se revocan tras su apostasía sino que se transfieren sencillamente a su padre (carta fechada 6 de octubre de 1609). MONTICONE, Alberto (1961), Paolo Sarpi, Lettere ai gallicani. Edizione critica, saggio introduttivo e note a cura di Boris Ulianich, Franz Steiner Verlag, Wiesbaden, p. 116; PRETO, Paolo (2010), I servizi segreti di Venezia: spionaggio e controspionaggio ai tempi della Serenissima, II Saggiatore, Milán, p. 348; y PRETO, Paolo (2013), Venezia e i Turchi, Viella, Roma, pp. 197-198.

14 Juan Vivas comenta en 1608 que han pasado 25 años desde el momento de su apresamiento («fue cautivo de moros habrá 25 años»). Archivo General de Simancas (en adelante AGS), Estado, L. 1932, ff. 512r-512v. 
Y efectivamente, en Levante Velasco no se limita a la navegación corsaria de nivel "medio-bajo", finalizada a la exclusiva acumulación de riquezas, sino que asciende a las altas esferas de la flota otomana. Durante «14 años continuos» navega al lado del "general Cigala», ${ }^{16}$ un renegado de origen italiano que en 1591 accede al cargo de Kapudan Pasha y da pie a una serie de campañas militares muy agresivas contra Persia y contra los Habsburgo de Austria, así como a numerosas expediciones de ataque a las costas del Mezzogiorno de Italia.

Aunque se encuentre fuera de los límites del Mar Adriático, Cigala lleva su flota a Calabria en más de una ocasión. En septiembre de 1594 sus hombres saquean e incendian algunas zonas de Reggio Calabria. ${ }^{17}$ Asimismo, es en aguas calabresas cuando en otoño de 1598 Scipione Cigala se reúne con su madre Lucrezia, 37 años después de su cautiverio. Para acudir al encuentro, que se realiza bajo la supervisión del virrey de Sicilia, el Kapudan Pasha zarpa desde Estambul con más de cincuenta naves y con esta pequeña armada consigue cruzar el estrecho de Messina sin encontrar grandes resistencias. Sin embargo, la opinión pública teme otro ataque a Calabria y sigue con gran preocupación a los movimientos de Cigala. ${ }^{18}$

Es importante destacar que el gran valor añadido que renegados como Pietro Velasco pueden ofrecer a los corsarios turco-berberiscos, por encima de todo talento personal, es precisamente su conocimiento del territorio enemigo. No es infrecuente que los cristianos de Alá pongan sus competencias lingüísticas y geográficas a disposición del Turco para facilitar las incursiones encaminadas a dañar las costas de Italia, Francia y España. Es una operación que tiene sus riesgos - no faltan los apóstatas que aprovechan de la cercanía con sus tierras natales para desertar y fugarse - pero los beneficios son considerables y el juego se mantiene en pie a pesar de todo.

15 «Habiendo renegado se casó y tuvo hijos en la parte de Levante» (Estado, L. 1932, ff. $512 \mathrm{r}-512 \mathrm{v})$. La creación de vínculos familiares es un índice de integración social muy importante, es por este motivo que las fuentes del Santo Oficio siempre destacan mucho las trayectorias matrimoniales y parentales de los cristianos de Alá. GONZÁLEZ-RAYMOND, La Croix et le Croissant, pp. 168-174.

16 AGS, Estado, L. 1932, ff. 512r-512v, 28 agosto 1608.

17 Sobre este episodio: TÜRKÇELIK, Evrim (2012), Cigalazade Yusuf Sinan Pasha y el Mediterráneo entre 1591-1606. Tesis Doctoral, Universidad Autónoma de Madrid, Madrid, pp. 197. 203.

18 Sobre la reunión entre Scipione Cigala y su madre: TÜRKÇELIK, Cigalazade Yusuf Sinan Pasha p. 309; y SOLA, Emilio (2007), La Conjura de Campanela, Turpin, Madrid, p. 68. Para una bibliografía completa de los historiadores sicilianos y napolitanos que nararron el evento en sus crónicas. Veáse también la tesis de Evrim Türkçeli. 
Aunque no tengamos pruebas concretas de ello, no es absurdo imaginar que la opinión de Pietro Velasco contribuya a configurar las mencionadas expediciones. Velasco, que ha sido cautivado en edad suficientemente madura como para haber sido ya tonsurado, no puede haber olvidado su tierra natal. Tanto la armada turca como los servicios de inteligencia de la Monarquía hispánica, aunque, como veremos, de formas opuestas, se aprovecharán de la procedencia de Velasco en beneficio propio.

\section{HUYendo de TuRquía}

Pese al éxito y a la fortuna acumulada en Turquía, a principios del siglo XVII Velasco decide abandonar la flota otomana y entrar al servicio de Florencia. Mientras todas las fuentes consultadas -tanto las hispanas como las italianas- silencian las circunstancias de su conversión al islam, es gracias a las segundas -concretamente a la correspondencia que el nuncio Antonio Grimani intercambió con Paulo V- que sabemos algo más sobre las circunstancias de su regreso a tierras cristianas y las de su reconciliación con la Iglesia. ${ }^{19}$

Por lo que respecta a la llegada de Velasco a Italia, esta es el resultado de una fuga muy aventurera. Adaptándose totalmente a la retórica del arrepentimiento religioso -absolutamente omnipresente en las fuentes hispanas del siglo XVI-XVII que hablan del reclutamiento de renegados por parte de la Monarquía Hispánica- ${ }^{20}$ en 1608 el embajador Juan Vivas describe la deserción de Velasco como el fruto de una iluminación espiritual - el segundo de Cigalazade deja Estambul «tocado por Nuestro Señor en el corazón», sin más.

Afortunadamente, resulta más completa la descripción que nos proporciona en 1606 la correspondencia de Antonio Grimani, nuncio apostólico en la Florencia de Fernando de Médicis. Si bien también apoyándose en la retórica del arrepentimiento religioso, Grimani nos devuelve el apasionante relato de una fuga empezada en el puerto de Quíos, fastidiada por tormentas, dificultada por la persecución de una escuadra de cincuenta jenízaros, ${ }^{21}$ y finalizada en Ancona, por supuesto gracias al amparo divino (ofrecido en este caso por la Virgen de Loreto). ${ }^{22}$

19 No olvidemos que, en los territorios sujetos a la jurisdicción del Santo Oficio (tanto español, como romano), la reconciliación por vía inquisitorial es teóricamente obligatoria para los cristianos de Alá.

20 Este es uno de los temas centrales de mi investigación doctoral. Profundizo más en OLDRATI, Valentina (2018), "Renegades and the Habsburg secret services in the aftermath of Lepanto: Haci Murad and the Algerian threat as a case study", Journal of Iberian and Latin American Studies, $n^{\circ} 24, \mathrm{pp} .7-26$. 
Dejando a un lado la cuestión de los remordimientos, insondable como todo tema espiritual, lo que sí podemos decir con certeza es que Velasco se va de Estambul dejando atrás todos sus bienes, hecho que cobraría bastante más sentido en el marco de una fuga repentina con trasfondos políticos, como por ejemplo el declive político y militar que sufre su patrón Cigalazade durante la última etapa de su vida.

Efectivamente, y como bien ha sido explicado por Evrim Türkçelik, en la segunda mitad de la década de 1590 la carrera del Cigala entra en una etapa crítica a raíz de la muerte del sultán Murad III (1595) y de la consiguiente reconfiguración de los equilibrios internos de la Corte otomana. ${ }^{23}$ La situación es fluctuante, como demuestra el entusiasmo con que se recibe la victoria obtenida por Cigalazade contra el archiduque Maximiliano en Hungría (1596), ${ }^{24}$ pero el clima general es bastante tenso. Para consolidar su poder, el nuevo Gran Visir y la madre del nuevo Sultán Mehmed III hacen lo posible para desacreditar a Cigalazade, y lo hacen insistiendo especialmente en sus orígenes cristianos y en sus sospechosas amistades y relaciones con cristianos (in primis con su hermano Carlo) y con cristianos renegados. ${ }^{25}$

No es absurdo imaginar que este afán recriminatorio tenga un impacto negativo en la vida y en la carrera de hombres como Pietro Velasco. A

21 Lo cual probaría la importancia alcanzada por Velasco dentro de la armada turca. Sin embargo, podría tratarse de una exageración.

22 Archivio Segreto Vaticano (en adelante ASV), Fondo Borghese, S. II, 303, ff. 71 r-71 v.

23 TÜRKÇELIK, Cigalazade Yusuf Sinan Pasha, pp. 205-256; y TÜRKÇELIK (2013), “El renegado "El Cigala' y la política mediterránea", Desperta Ferro. Historia Moderna, n 6, pp. 40-43.

24 El Sultán premia a Cigalazade con el prestigioso título de Gran Vizir. Cigalazade mantiene el título durante unos meses, pero la rebelión de las tropas kurdas y las conspiraciones de palacio llevan al sultán a revocar su nombramiento. Al cabo de poco tiempo, Cigala será nuevamente nombrado Gran Vizir y también General de la mar. Cfr.: BUONFIGLIO COSTANZO, Giuseppe (1604), Prima [e secundi] parte dell'Historia siciliana, Bonifacio Ciera, Venecia, p. 678; y MONTUORO, Domenico (2009), "I Cigala, una famiglia feudale tra Genova, Sicilia, Turchia e Calabria", Mediterranea: Richerche Storiche, n 6, p. 289.

25 Dice la leyenda que Lucrezia, madre de Scipione e hija del bey de Castelnuovo, se había casado con el padre de Cigalazade tras haber sido apresada con ocasión de la toma del puerto montenegrino en 1538. Los orígenes mixtos de Scipione, pese a ser un poco turbios para los estándares españoles de limpieza de sangre, nunca representan un problema en las fuentes cristianas. Sin embargo, el hecho de que la madre del Cigalazade haya abandonado el islam en favor del cristianismo es bastante mal visto en Turquía, y los detractores de Cicala no pierden ocasión para preguntarse públicamente si la conversión de Lucrezia no pueda exponer el almirante al peligro de convertirse a su vez a la religión cristiana. Cfr.: OCAKAÇAN, Levent Kaya (2015), "Cigalazade Yusuf Sinan Pasha (C. 1545-1606)", Mediterranea: Richerche Storiche, Palermo, $n^{\circ} 12$, pp. 325-340; y MAS, Albert (1967), Les Turcs dans la littérature espagnole du Siècle d'Or: recherches sur l'évolution d'un thème littéraire, Centre de Recherches Hispaniques, París, Vol. 2, pp. 272-273. 
veces por conveniencia y a veces huyendo de un peligro inminente, no falta quien tome el camino de la defección y busque nuevos patrones a los cuales ofrecer sus competencias y servicios.

\section{Al servicio del Gran Duque}

Muy interesante es también la cuestión de la reconciliación de Pietro Velasco, un trámite de naturaleza política que suscita cierto debate entre el Papado, Fernando I, y el tribunal inquisitorial de la capital medicea.

Aunque en la Florencia de comienzos del siglo XVII exista un tribunal perfectamente capacitado para reconciliar a todos los cristianos de Alá, ${ }^{26} \mathrm{Ve}$ lasco consigue canjear sus cargos inquisitoriales por un simple peregrinaje penitencial a Roma (1606). Gracias a las presiones del gran duque, transmitidas a Roma con la mediación del nuncio Grimani, el pontífice hace expedir un salvoconducto con validez de seis meses, en virtud del cual Velasco alcanza la capital, hace penitencia y es readmitido en la Orden dominica, todo ello sin pasar por los inconvenientes normalmente causados por un proceso inquisitorial:

Questo fu frate di San Domenico et per rimorso di coscienza è voluto ritornare alla vera fede, è pronto di venir a Roma ad humiliarsi et a ricevere ogni penitenza et a ripigliarsi l'abito della sua Religione et perciò ha procurato un salvocondotto della Sacra Congregazione di venire a Roma dentro a sei mesi del quale io ho veduto copia. Hora mentre si aspettava questo salvocondotto il Padre Inquisitore di Firenze è stato a Pisa, et avendo fatto personalmente istanza di avere costui nelle mani, Sua Altezza gli ha detto che lo terrà in Castello fin a nuovo ordine da Roma, et che gli pareva strano che contro chi spontaneamente veniva ad umiliarsi [si procedesse] con questo rigore, et che questo era un levare l'animo agli altri rinnegati che avessero voglia di ritornare nel gremio della Chiesa, et dopo questa istanza dell'inquisitore venne il salvocondotto. Mi ha perció Sua Altezza ostinatamente pregato che supplichi Sua Santità che si contenti che questo uomo faccia qui l'abiurazione in mano dell'Inquisizione e di Firenze et di Pisa, con tutto quel di più che sarà necessario per tale effetto, et che farà ogni penitenza et ripiglierà l'abito, et questo

26 Sobre el tribunal de Florencia: PROSPERI, Adriano (2011), "Firenze", en PROSPERI, Adriano, LAVENIA, Vincenzo y TEDESCHI, John (coords.). Dizionario storico dell'Inquisizione, Edizioni Normale di Pisa, Pisa, Vol. 2, pp. 605-607. 
desidera Sua Altezza per due rispetti, l'uno per non spaventare gli altri rinnegati di ritornare alla fede, l'altro perché ha tanto bisogno del consiglio di costui per servizio dell'impresa contro Turchi, che concorrono ante il servizio della Cristianità. ${ }^{27}$

Es interesante notar que, para deslegitimar las peticiones del inquisidor de Florencia -cargo que entre 1606 y 1615 fue ocupado por el franciscano Cornelio Priatoni da Monza- Grimani atribuye a Fernando I un discurso sobre la importancia de la templanza inquisitorial ante el fenómeno de los cristianos de Alá que a principio del siglo XVII está ya muy extendido en todos los territorios que están sujetos a la jurisdicción del Santo Oficio, ambos romano y español. Si el objetivo de la lglesia es favorecer el regreso a tierras cristianas del mayor número de renegados posible -argumenta Grimani a través del gran duque- causar inútiles inconvenientes a un penitente espontáneo y tan bien dispuesto como Velasco no puede ser sino una decisión corta de miras y contraproducente. ${ }^{28}$

Como también subraya Francesco Vitali, estudioso de la Nunciatura Apostólica en la Florencia de 1587-1609, Velasco es el hombre adecuado para convertir en realidad el sueño de una expedición naval antiotomana bajo la égida de las galeras de Toscana, lo cual explica la gran obstinación mostrada por su reclutador frente a todo inconveniente práctico o burocrático que ponga en riesgo su rápida reinserción en la sociedad italiana. ${ }^{29}$

Fernando I mira hacia Oriente para fortalecer la posición de Toscana y de la Orden de Santo Stefano dentro del escenario político italiano, ${ }^{30}$ y Chipre es el objetivo militar perfecto para ello. Caída en manos otomanas en 1571, Chipre se encuentra efectivamente en una situación estratégica inmejorable tanto de cara a una eventual recuperación de los Santos Luga-

\section{ASV, Fondo Borghese, S. II, 303, ff. 71 r-71v.}

28 Sobre el tema de la spontanea comparitio, cfr.: BRAMBILLA, Elena (2006), La giustizia intollerante. Inquisizioni e tribunali confessionali in Europa (secoli IV-XVIII), Carocci, Roma, pp. 6871; y BRAMBILLA, Elena (2000), Alle origini del sant'Uffizio. Penitenza, confessione e giustizia spirituale dal Medioevo al XVI secolo, II Mulino, Bolonia, pp. 381-402.

29 Velasco aparece en el párrafo que Vitali dedica a la nunciatura de Antonio Grimani en Florencia (1605-1616), aunque sin que el autor haga referencia al sucesivo pasaje de este capitán al servicio de Felipe III. Sin embargo, las detalladas referencias de archivo ofrecidas por Vitali nos han permitido acudir a las fuentes vaticanas y encontrar informaciones de gran interés sobre la reconciliación de reclutas renegadas de alto rango en el contexto de las relaciones entre Roma y la Toscana de los Médicis. Cfr.: VITALI, Francesco (2017), I nunzi pontifici nella Firenze di Ferdinando I (1587-1609), Nuova Cultura, Roma, pp. 156-170.

30 Incluso después del fracaso chipriota, Toscana no dejará de mirar hacia Levante. En septiembre de 1607 los caballeros de Santo Stefano, encabezados por Silvio Piccolomini, conquistarán Bona (actual Annaba, en el noreste de Argelia). En 1613 Fernando I acogerá en Florencia 
res, como para llevar la guerra al interior de Turquía. ${ }^{31}$ Al mismo tiempo, el mito del martirio de Marcantonio Bragadino, ${ }^{32}$ desollado vivo en plaza de Famagusta, y los constantes llamamientos que la población cristiana de Chipre hace a Toscana, España y a los duques de Saboya confieren a la Reconquista de la isla un altísimo valor simbólico. ${ }^{33}$

No es difícil entender porque el gran duque, que ha recibido «infiniti servizi de un Capitano Pietro Velasco calabrese nell'imprese delle sue galere» y que espera recibir muchos otros "ne i disigni che ha contro il Turco», ${ }^{34} \mathrm{sim}$ plemente no vea con buen ojo que algo frene la salida de Velasco a la mar. En cualquier caso, el fuerte interés que Fernando I tiene en la rápida e indolora rehabilitación de Velasco no debería engañarnos. Las relaciones entre los dos son borrascosas y desde el primer momento, tanto en lo personal como en ámbito militar.

Las primeras fricciones surgen incluso antes de que Velasco viaje a Roma, cuando el gran duque descubre, por una carta del cardenal Arrigoni, ${ }^{35}$ que tras llegar a Italia el capitán Velasco se ha casado secretamente con una mujer griega, hecho incompatible con el estatuto sacerdotal que el

al desertor Fakhreddin, príncipe de la provincia libanesa de Sidon. Tras pasar un tiempo en, Fakhreddin moverá su residencia a Messina (1615) y luego a Nápoles (1616), donde residirá hasta volver a Líbano en 1618. Incluso tras regresar a su tierra natal, Fakhreddin no dejará de vender informaciones a sus contactos italianos e hispanos. El propio emir ha escrito una memoria de su viaje a Italia, que ha sido traducido al italiano en 1936: CARALI, P. Paolo (1936), "Soggiorno di Fakhr ad-dīn al-Ma'nī in Toscana, Sicilia e Napoli e la sua visita a Malta (1613-1618)", Annali del Istituto Superiore Orientale di Napoli, n 4.

31 Sobre Chipre a comienzos del siglo XVII y la expedición toscana de 1607: HILL, George (1952), A History of Cyprus: The Ottoman Province, the British Colony, 1571-1948 (Vol. 4), Cambridge University Press, Cambridge; FLORISTÁN, José M. (1988), Fuentes para la política oriental de los Austrias. La documentación griega del Archivo de Simancas (1571-1621), Universidad de León, León, pp. 693-737; FLORISTÁN, José M. (2016), "Relación de la empresa de Famagusta (1607)", Archivo de la Frontera, <http://www.archivodelafrontera.com/ wp-content/uploads/2016/09/1607-EMPRESA-DE-FAMAGUSTA-JM-Florist\%C3\%A ln.pdf>; HADIIANASTASIS, Marios (2014), "Corsair tactics and lofty ideals: the 1607 Tuscan raid on Cyprus", en WALSH, Michael (ed.), Historic Famagusta: A Millennium in Words and Images, Cambridge Scholars Publishing, Cambridge, pp. 22-36; y GEMIGNANI, Marco (2003), "The navies of the Medici: The florentine navy and the navy of the sacred Military order of saint stephen, 1547-1648", en HATTENDORF, John y UNGER, Richard (eds.), War at Sea in the Middle Ages and the Renaissance, Boydell press, Woodbridge, pp. 169-185.

32 Rector de la fortaleza en el día de su conquista otomana. Muere en fecha 17 de agosto de 1571.

33 HADJIANASTASIS, "Corsair tactics and lofty ideals", p. 24.

34 ASV, Fondo Borghese, S. II, 303, ff. $71 \mathrm{r}-71 \mathrm{v}$.

35 A partir de 1605 Pompeo Arrigoni fue el secretario de la Sagrada Congregación de la Romana y Universal Inquisición. 
ex-renegado pretende recuperar a través del perdón papal. Irritado por los subterfugios de su criado, Fernando I le encarcela.

Grimani, como siempre atento observador de la Corte florentina y de los humores de su carismático líder, se sorprende por esta "repentina mutazione» hasta el punto de declararse «il più confuso vomo del mondo», y comunica prontamente con Roma sobre el encarcelamiento de Velasco. Disgustado, pero consciente de las cualidades militares de su recluta, el gran duque termina liberando a Velasco, que se dirige hacia los estados pontificios tal y como pactado ("Sua Altezza era tanto sdegnata contro costui per avere ... inteso che aveva sposato una greca ch'essendogli fatta istanza che lo mandasse a Roma, aveva volute anteporre la soddisfazione di Sua Santità ai propri interessi»). ${ }^{36}$ De la mujer griega con la cual Velasco se ha casado en Florencia no tenemos más trazas. ${ }^{37}$

Y los inconvenientes generados por Velasco no se limitan a su irregular conducta privada: su indocilidad llega a causar problemas también de orden público, como nos muestra la noticia de una pelea ocurrida entre Velasco y Francesco Mancini da Montepulciano, caballero de Malta, con ocasión de la cual nuestro ex-renegado resulta herido por su adversario (1607). ${ }^{38}$

Superadas las dificultades en el plano personal, empiezan las dificultades de tipo militar. Según leemos en la «Relación de lo que an hecho en Levante las galeras del gran duque y el sucesso de Famagusta», editada y publicada por José Manuel Floristán Imizcoz, Fernando I deja de lado todo desacuerdo y resuelve poner a Pietro Velasco a la cabeza de uno de los navíos toscanos que intentan tomar Famagusta en mayo de 1607 («marciava di vanguardia il capitano Pietro Velasco con un petardo in compagnia di 25 huomini»). ${ }^{39}$

36 ASV, Fondo Borghese, S. II, 303, ff. 76r-76v; ASV, Fondo Borghese, S. II, 303, f. 77r.

37 En su informe para Felipe III, Juan Vivas comenta que Fernando manda que la mujer de Velasco sea bautizada y metida a monja. Sin embargo, se refiere a la mujer - turca de nacimiento con la cual Velasco se ha casado en Turquía y con la cual ha huido de Quíos. La boda que provoca la indignación de Fernando es posterior, tiene lugar en Toscana e involucra con toda probabilidad a una mujer cristiana. AGS, Estado, L. 1932, ff. 512r-512v.

38 CAPPONI, Gino (1845), Catalogo dei manoscritti posseduti dal Marchese Gino Capponi, Coi Tipi della Galileiana, Florencia, pp. 13-14. Estos son los títulos completos de los dos manuscritos del Fondo Capponi que refieren a Pietro Velasco, y que esperamos localizar y consultar en una futura estancia de investigación: "88. Deliberazione fatta il primo di luglio (1607), sopra il capo della Grecia, del signor Ammiraglio, Capitan Pietro Velasco et altri intendenti, sopra quello che si deve far delle galere"; "n. 89. Vari costituti nel processo formato per la rissa accaduta tra il Capitano Pietro Velasco di Calabria, ferito dal cavalier Francesco Mancini da Montepulciano (1607)". Gino Capponi fue un político e historiador florentino (1792-1876). Su biblioteca personal fue donada a la Biblioteca Nazionale di Firenze en 1879 y contiene numerosos manuscritos de gran interés histórico. 
Se trata de una posición de gran relieve si consideramos que Velasco comparte el mando con personajes del calibre de Francesco del Monte -estimado general y autor de una interesante crónica de la jornada titulada "Impresa di Famagosta" - ${ }^{40}$ y Antonio de Médicis -sobrino del propio gran duque, caballero de la Orden de Malta, y diplomático de perfil internacional. ${ }^{41} Y$ es tal vez por este motivo que el otomanista Marios Hadjianastasis confunde nuestro Pietro Velasco, ex-renegado de origen calabrés, con Pedro Téllez-Girón y Velasco, gran duque de Osuna y futuro virrey de Sicilia (1610-1616).42 Sin embargo, cabe señalar que su reconstrucción de la ofensiva medicea realizada a través de la crónica redactada por Del Monte y de fuentes procedentes del archivo de la familia Piccolomini de Siena- sigue siendo muy detallada, y permite seguir prácticamente todos los movimientos efectuado por Velasco en Famagusta. ${ }^{43}$

Pese a las grandes expectativas -Velasco había prometido entregar Chipre en virtud de su excelente conocimiento del Mediterráneo oriental, por lo menos según las declaraciones de Juan Vivas («[dijo] que le diera a Cipro si hizieran lo que dixo»|-44 la misión chipriota falla míseramente. Para empeorar las cosas, una de las causas del fracaso florentino -al margen de la gran capacidad de reacción mostrada por el ejército turco- ${ }^{45}$ es precisa-

39 AGS, Estado, L. 1162, ff. 200-201 (la relación se remite a Madrid desde Mesina, junto con una carta del virrey de Sicilia Juan Fernández Pacheco, duque de Escalona). Publicado por FLORISTÁN, Fuentes para la política oriental de los Austrias, pp. 716-721.

40 Fuente citada por: HADJIANASTASIS, "Corsair tactics and lofty ideals", p. 24. Referencia de archivo: Biblioteca Comunale degli Intronati de Siena, K. II.16, ff. 132-176 ("Impresa di Famagosta: Giustificatione dell'lllustrissimo Signore Francesco del Monte").

41 Sobre la misión: ASV, Fondo Borghese, S. II, 302, f. 175r. Nótese que este mismo volumen contiene varias noticias sobre la preparación y el fracaso de la misión.

42 Así escribe Hadjianastasis en el artículo arriba citado: "There were also other noble participants: Don Antonio de' Medici, the late Granduke Francesco I's son with his ten mistress (and future wife) Bianca Cappello, was part of the expedition; so was Pietro Velasco, the future Duke of Osuna and Viceroy of Sicily». HADIIANASTASIS, "Corsair tactics and lofty ideals", p. 26.

43 Por ejemplo, gracias a la reconstrucción de Hadjianastasis sabemos que Velasco llega a Chipre al mando de las petardas (p. 27). Más tarde, cuando se decide atacar a la fortaleza escalando su muralla, la compañía de Pietro Velasco se moviliza en apoyo a la de Pietro Viscardo, encargado de penetrar por el lado sur del castillo (p. 29). Pasando ya a la etapa final del asalto, Hadjianastasis ubica a Velasco entre los hombres que atacan la fachada noreste del castillo, donde la contemporánea reagrupación de cuatro compañías genera una parálisis que termina colocando a las tropas toscanas totalmente a la merced del fuego enemigo, (p. 31). Finalmente, tras retirarse la armada en Pannaia (una bahía ubicada a 10 millas de Famagusta), Velasco muestra ser ferozmente partidario de mover otro ataque a la fortaleza. Para ello promete reunir a un ejército de griegos, pero la misión fracasa (pp. 33-34).

44 AGS, Estado, L. 1932, ff. 512r-512v. 
mente la mala planificación del ataque, debida a un total desconocimiento de las murallas de Famagusta, ${ }^{46}$ y a la tardía llegada de las galeras de Montecuccoli. ${ }^{47}$

Consideradas las promesas hechas por Velasco, no es improbable que sea el fracaso de la misión la razón de la ruptura entre nuestro capitán y Florencia. Una carta que Grimani envía a Paulo V el 4 de agosto de 1607, y en la cual se habla de una posible fuga de Velasco a Calabria, parece confirmar nuestras sospechas: el fracaso chipriota ha quitado credibilidad a Velasco, y su largo historial de cambios de bando no hace sino empeorar la situación. ${ }^{48}$

\section{De Toscana a la Monarquía hispánica}

Legítimos $O$ no, el autoritarismo y la constante vigilancia ejercitados por Fernando tras Chipre ponen duramente a prueba a Velasco, que en 1608 decide abandonar Florencia en favor España. La notoria receptividad mostrada por la Monarquía hispánica hacia el reclutamiento de renegados y ex-renegados, siempre y cuando fuesen colaborativos y "de buen rango", convierten a Felipe III en un patrón ideal para los objetivos de nuestro capitán, cuyas propiedades e hijas han sido secuestradas de forma preventiva por el tercer gran duque. ${ }^{49}$

Las tentativas autonomistas introducidas por el "francesista" Fernando I y las consecuentes tensiones en que se traducen en las relaciones Habsburgo-Mediceas, ${ }^{50}$ deben facilitar aún más el proceso decisorio del ex-renegado, seguro de encontrar en Madrid unos patrones a la altura de su potencial.

45 Aunque se realice de madrugada, la llegada de las galeras de Florencia no pasa desapercibida, con lo cual el desembarco no puede contar con el factor sorpresa.

46 Se subestima la altura de la muralla exterior de Famagusta (de hecho, las escaleras empleadas para subirla resultan ser demasiado cortas) y se desatiende la existencia de una segunda muralla interior.

47 Alessandro Montecuccoli había sido lugarteniente de los soldados de Siena bajo Alessandro I de Médicis. Al asalto de Famagusta participó con cinco barcos. Véase FLORISTÁN, "Relación de la empresa de Famagusta (1607)".

48 ASV, Fondo Borghese, S. II, 306, f. 40v.

49 Así se describe la situación de Velasco a Felipe III: «le hará mucho servir a Vuestra Magestad y salir del Duque porque le ha tomado la hacienda y las hijas de temor que no se le vaya». Ibidem.

50 Fernando I es mucho más audaz que su padre Cosimo, por lo menos en su relación con Espa- 
Para este efecto, y estando en Génova para comprar un barco, Pietro decide entonces ponerse en contacto con el embajador de España, Juan Vivas de Cañamás. La proximidad geográfica con Toscana y la vinculación política con Madrid convierten la Repubblica en un sitio ideal para un potencial desertor como Velasco. ${ }^{51}$ Por añadidura, Vivas es un atento observador del escenario chipriota, ${ }^{52}$ y ha consagrado ya notables esfuerzos a neutralizar la amenaza turco-berberisca en el Mediterráneo occidental, vigilando los movimientos de los moriscos de Valencia y Cataluña e informando constantemente a Madrid al respecto. ${ }^{53}$

$Y$ efectivamente Vivas cumple con las expectativas: entusiasmado, escribe enseguida a Felipe III con el objetivo de recomendar el reclutamiento de Velasco, que mientras tanto sigue oficialmente a sueldo toscano. ${ }^{54}$

Aparte de describir las cualidades del capitán y de omitir casi toda referencia a su historial de traiciones político-religiosas, ${ }^{55}$ nos parece interesante que el mensaje de Vivas haga referencia a la procedencia del ex-apóstata subrayando, de forma sutil pero no casual, su condición de súbdito de la

ña. No solamente interviene en las guerras de religión francesas al lado del protestante Enrique IV, sino que también consigue que este se case con su sobrina Maria de Médicis en 1599. Sobre Fernando I de Médicis y el giro al "francesismo" de la política toscana, cfr.: GONZÁLEZ TALAVERA, Blanca (2011), Presencia y mecenazgo español en la Florencia Medicea: de Cosme I a Fernando I. Tesis Doctoral, Universidad de Granada, Granada, pp. 74-78; HANLON, Gregory (1998), The Twilight of a Military Tradition: Italian Aristocrats And European Conflicts, 1560-1800, Routledge, Londres, pp. 39-40.

51 Manuel Herrero Sánchez se ha servido de la eficaz fórmula "agregado hispanogenovés" para describir las relaciones entre la República de Génova y la Monarquía Hispana durante los siglos XVI y XVII: HERRERO SÁNCHEZ, Manuel (2001), "Una república mercantil en la órbita de la Monarquía Católica (1528-1684)", en ANATRA, Bruno y MANCONI, Francesco (eds.), Sardegna, Spagna e Stati Italiani nell'Età di Carlo V, Carocci, Roma, pp. 183-200.

52 Vivas escribe varias cartas a Felipe III sobre la fallida insurrección chipriota de 1606. En ellas afirma que la población local podría fácilmente aliarse con España con tal de emanciparse del Turco. Cfr.: LUBIN, Matthew (2011), Aftermath of War: Cypriot Christians and Mediterranean Geopolitics, 1571-1625. Tesis Doctoral, The University of North Carolina at Chapel Hill, Chapel Hill, p. 134. Fuentes citadas: AGS, Estado, L. 1434, docs. 47, 102, 117.

53 Vivas escribió varias cartas a Felipe III para informarle sobre los moriscos que hacían escala en Francia antes de zarpar hacia Argel. Cfr.: GIL HERRERA, Jorge y BERNABÉ PONS, Luís F (2014), "The Moriscos Outside Spain. Routes and Financing", en GARCÍA-ARENAL, Mercedes y WIEGERS, Gerard (eds.), The Expulsion of the Moriscos from Spain: a Mediterranean diaspora, Brill, Leiden, pp. 222-223.

54 Con fecha 6 de julio de 1608 Juan Vivas había remitido a Felipe III las siguientes informaciones: «El gran duque también sale con su armadilla y ha enviado delante cuatro galeras con fray Pedro Velasco, llevarán en todo diez galeras y cosa de quince bajeles redondos sin otros pequeños». Se deduce que Velasco era un personaje conocido dentro del panorama militar mediterráneo. AGS, Estado, L. 1434, doc. 121. 
Corona, nacido en Calabria, y además «hijo de español natural de esta villa de Madrid».56

Como súbdito de Felipe III, Velasco tiene una obligación moral no solamente hacia su rey, sino también hacia la causa de la verdadera fe: dos obligaciones intrínsecamente ligadas entre si, hecho que los servicios de inteligencia de la Monarquía hispánica difícilmente se olvidan de destacar cuando intentan el reclutamiento de un renegado entre los siglos XVI y XVII. Es así que el reclutamiento de Velasco, elevado a justo retorno de una oveja descarriada, sirve a España para fastidiar no solamente al Turco, sino también a los Médicis e, indirectamente, a un pez incluso más gordo: la Francia de Enrique IV.

\section{FORMAS DE PATRONAZGO... Y DE MUTUO ESTORBO}

En el Mediterráneo del siglo XVII la promoción del talento, se ha visto claramente, es una práctica "trans-imperial". Lo es en cuanto común a todas las formaciones políticas dotadas de medios económicos adecuados, y lo es en cuanto subproducto de unas rivalidades que ven en la sustracción de recursos humanos una estrategia bélica doblemente triunfadora, por su capacidad de usar la fuerza del enemigo -en este caso en forma de capital humano- en su contra.

La armada otomana forma y da responsabilidades militares al joven Velasco, nacido cristiano y fuera del imperio, Florencia lo recluta cuando ya es un marinero experto y deseoso de cambiar de aires, y lo mismo se proponen hacer los Habsburgo de España cuando la historia se repite. En cada una de estas coyunturas, el reclutamiento de Pietro Velasco corresponde a una voluntad de "promoción del talento", pero también puede verse como un efecto secundario de rivalidades políticas y militares: se trata, para emplear una fórmula que sintetice nuestra interpretación, de estrategias de "asimilación antagonista", encaminadas a ofrecer un beneficio interno con el complemento de un estorbo externo.

Especialmente interesante es, en este sentido, la cuestión del "ascensor social otomano". El historiador húngaro Gabor Ágoston habla del uso de expertos extranjeros por parte del Imperio Otomano a través de la fórmula

55 Fuera de comentar que «aviendo renegado se cassó y tuvo hijos en la parte de Levante». Para lo que atañe a las cualidades de Velasco: «se tiene por cierto no aver en la christiandad hombre mas plático en la mar contra los Turcos, pues demas de saver los puertos y plazas sabe las costumbres y el modo en que se ha de navegar y se ha de llevar una armada Real».

[AGS, Estado, L. 1932, ff. 512r-512v.]

56 Ibidem. 
"the human pool of military acculturation" ("la reserva humana de aculturación militar"), ${ }^{57}$ evidenciando como ya a partir de la época de Mehmed II (1432-1481) el imperio dedicó importantes recursos a quitar a sus enemigos (o importar, según el enfoque) expertos del arte militar - capitanes y soldados, pero también autores de tratados, ingenieros, y artesanos -y como su contribución se acompaña frecuentemente a la conversión religiosa, hecho en ocasiones voluntario, pero mucho más a menudo resultado de la manumisión, a su vez medio de salida desde el cautiverio.

El camino que llevó Velasco del cautiverio a las altas esferas del ejército otomano, pasando por la apostasía, coincide efectivamente con la gran mayoría de los renegados que negociaron la venta de servicios a potencias cristianas. Los ejemplos abundan.

Uchalí, probablemente el renegado más conocido de todos los tiempos, pasa de ser cautivo del griego Khayr al-Dīn Barbarossa, a yerno y protegido del convertido calabrés Jafer Rais, su segundo amo. Gracias a una espectacular carrera militar, Uchalí termina ascendiendo a los cargos más altos de la administración otomana, entre ellos los de gobernador de Argel (1568) y de Gran Almirante de la armada otomana (1571)..$^{58}$ A partir de 1568, y durante más de veinte años, los Habsburgo de España responden a los retos planteados por Uchalí oscilando entre intricadas conspiraciones homicidas y acercamientos diplomáticos en plena regla. ${ }^{59}$

Juan de Briones, Robert Draver y Pedro/Pietro Brea - tres agentes dobles muy implicados en el famoso circulo de espías que Giovanni Margliani monta en el Estambul de Selim II - pasan de cautivos a criados de Uchalí, y como tales cooperan con los servicios de inteligencia de la Monarquía hispánica. Especialmente interesante es el caso de Brea, escribano personal de Uchalí, que filtra información sacada de la correspondencia del Kapudan Pachá a cambio dinero, títulos y rentas para sí mismo y para su familia. ${ }^{60}$

57 ÁGOSTON, Gabor (2006), Guns for the Sultan: Military Power and the Weapons Industry in the Ottoman Empire, Cambridge University Press, Cambridge, pp. 42-48.

58 Bibliografía esencial sobre este personaje: SOLA, Emilio (2011), Uchali: el calabrés tiñoso o el mito del corsario muladí en la frontera, Ediciones Bellaterra, Barcelona; SOLA, Emilio y DE LA PEÑA, José (1995), Cervantes y la Berbería: Cervantes, mundo turco-berberisco y servicios secretos en la época de Felipe II, Fondo de Cultura Económica, Madrid, pp. 72-82; y KOLOĞLU, Orhan (2007), "Renegades and the case Uluç/Kiliç Ali", en CANCILA, Rosaria (ed.), Mediterraneo in armi (secc. XV-XVIII), Quaderni di Mediterranea, Palermo, pp. 527-531.

59 GÜRKAN, Emrah Safa (2014), "Money or Your Life: The Habsburg Hunt for Uluc Ali", Studia Historica: Historia Moderna, Salamanca, n³6, pp. 121-145. 
Saliendo del ámbito estrictamente hispano, también Hasan Veneciano, nacido en Venecia con el nombre de Andreta Celeste, pasa de ser una víctima de las razzías de Dragut (1563) a ocupar los cargos beylerbey de Argel (1577-1580 y 1582-1585), de pachá de Trípoli (1587-1588), y finalmente de Kapudan Pasha (1588-1591). Una vez más, es el amparo de su apresador - y de Uchalí, a partir de 1565 - lo que le permite aprender el oficio de marinero y ascender a los más altos cargos de la administración turca. ${ }^{61}$ En las décadas de 1570 y de 1580, tanto Venecia como España invierten grandes sumas de dinero para tratar de comprar su colaboración. ${ }^{62}$

Finalmente también Scipione Cigala, el propio patrón de Velasco, pasa del cautiverio a la escuela del Serrallo, y de ahí a la armada otomana. ${ }^{63}$ Cigala, que cae víctima de corsarios turcos con tan sólo 17 años de edad, ha tenido ya bastante experiencia marítima navegando junto con su padre, el Vizconde Cigala, y lleva esta experiencia consigo en el camino de aprendizaje que emprende dentro el Enderún (la escuela imperial). ${ }^{64}$ Como bien explica Türkçelik, el padre Scipione ha dedicado toda su vida al corso contra el Turco, y por tanto «el principal valor que atesora Cigala para los otomanos es, en gran parte, su procedencia italiana sellada en la conservación de su apellido familiar en forma otomanizada», nomenclatura que permite a Estambul valerse irónica y públicamente del hijo de un servidor de la Corona en contra de la propia Monarquía. ${ }^{65}$ Décadas más tarde (concretamente entre 1593 y 1601), España devuelve el favor a Turquía intentado reclutar al Cigala por vía de su hermano, Carlo. ${ }^{66}$

60 OLDRATI, Valentina (2015), "Pedro Brea, un genovés en Constantinopla: veinte años de espionaje y contra-espionaje entre Madrid, Nápoles, Génova e Imperio otomano (1578-1596)", en SOLA, Emilio y VARRIALE, Gennaro (coords.), Detrás de las apariencias: información y espionaje (siglos XVI-XVII), Universidad de Alcalá, Alcalá de Henares, pp. 153-173.

61 Para un cuadro biográfico introductorio, cfr.: FABRIS, Antonio (1997), "Hasan 'il veneziano' tra Algeri e Costantinopoli", Quaderni di Studi Arabi, n 15 (suppl.), pp. 51 -66; y DURSTELER, Eric (2006), Venetians in Constantinople: Nation, Identity, and Coexistence in the Early Modern Mediterranean, Johns Hopkins University Press, Baltimore, pp. 123-126.

62 GÜRKAN, Emrah Safa (2016), "His Bailo's Kapudan: Conversion, Tangled Loyalties and Hasan Veneziano between Istanbul and Venice (1588-1591)", Journal of Ottoman Studies, $n^{\circ} 48$, pp. 277-319.

63 TÜRKÇELIK, Cigalazade Yusuf Sinan Pasha; IDEM, "El renegado 'El Cigala' y la política mediterránea"; OLIVA, Gaetano (1907-1908), "Sinan Bassà (Scipione Cicala) celebre rinnegato del secolo XVI: Memorie storico-critiche", Archivio Storico Messinese, Mesina, n 8/9, pp. 266-303; y OCAKAÇAN, "Cigalazade Yusuf Sinan Pasha".

64 El vizconde es apresado junto con su hijo. Sin embargo, mientras Scipione se queda en Turquía, su padre consigue rescatarse y volver a Sicilia. 
Tanto las trayectorias turcas de hombres como Uchalí - del cautiverio al éxito profesional - como las negociaciones que estos entablan con potencias cristianas como España, Venecia, y Francia, tienen en la segunda mitad del siglo XVI su época de oro. Si el siglo XVII nos ofrece menos casos de este tipo, desde luego no es porque el Mediterráneo haya cesado de ser un mar de piratas y corsarios. ${ }^{67}$ Más bien, los otomanos dejan progresivamente de ascender a cristianos a puestos de prestigio y poder - musulmanes nuevos incluidos - debido a "teologización" del discurso político que se impone de forma creciente a partir de los reinados de Solimán el Magnífico (15201566), Selim II (1566-1574), y Murad III (1574-1595). .8 Asimismo - y especialmente para lo que atañe a los cristianos de Alá - resulta cada vez más evidente que la promoción de outsiders no es garantía de lealtad, y que los vínculos de solidaridad étnico-regional terminan afectando al Imperio mucho más de lo inicialmente esperado. ${ }^{69}$

Sin embargo, en los albores del siglo XVII la promoción del talento sigue teniendo importancia en la sociedad otomana. Las contemporáneas sociedades cristiano-europeas, más rígidas y estamentales, funcionan de forma distinta. Difícilmente un humilde pescador como Dioniso Galea, futuro Uchalí, podría convertirse en el Capitán General de la armada de Felipe II. A pesar de ello, la trayectoria de Pietro Velasco pone de manifiesto un curioso mecanismo: la necesidad de conocer al enemigo, para mejor debilitarle, hace irónicamente posible que, incluso en tierras cristianas, repercutan los efectos del sistema de promoción otomano. Cautiverio, promoción del talento y rivalidades internacionales se fusionan así en el juego de la asimilación antagonista.

65 TÜRKÇELIK, Cigalazade Yusuf Sinan Pasha, pp. 14-15.

66 GRAF, Tobias (2017), "Trans-Imperial Nobility: The Case of Carlo Cigala (1556-1631)", en NORTON, Claire (ed.), Conversion and Islam in the Early Modern Mediterranean: The Lure of the Other, Routledge, Londres, pp. 9-29; y PAPPALARDO, Salvatore (2009), "Ambizione politica, commercio e diplomazia alla fine del XVI secolo: Carlo Cicala", en ZACCARIA, Claudio, ANDREOZZI, Daniele y PANARITI, Loredana (eds.), Acque, terre e spazi dei Mercanti: istituzioni, gerarchie, conflitti e pratiche dello scambio dall'età antica alla modernità, Editreg, Trieste, pp. 141-168.

67 El siglo XVII ha sido definido como la época de oro de la piratería. Cfr.: BONO, Salvatore (1993), Corsari nel Mediterraneo: cristiani e musulmani fra guerra, schiavitù e commercio, Mondadori, Milán.

68 KRSTIĆ, Tijana (2009), "Illuminated by the Light of Islam and the Glory of the Ottoman Sultanate: Self-Narratives of Conversion to Islam in the Age of Confessionalization", Comparative Studies in Society and History, $\mathrm{n}^{\circ}$ 51, pp. 35-63. El desmantelamiento de la devshirme, que a partir de la década de 1630 cae de facto en desgracia, es sólo uno de los muchos efectos de esta "confesionalización".

69 Metin Ibrahim Kunt ha acuñado esta expresión. KUNT, "Ethnic-regional (cins) solidarity", pp. 233-239. 


\section{Bibliografía}

ÁGOSTON, Gabor (2006), Guns for the Sultan: Military Power and the Weapons Industry in the Ottoman Empire, Cambridge University Press, Cambridge.

BENNASSAR, Bartolomé (1989), Los cristianos de Alá: la fascinante aventura de los renegados, Nerea, Madrid.

BONO, Salvatore (1993), Corsari nel Mediterraneo: cristiani e musulmani fra guerra, schiavitù e commercio, Mondadori, Milán.

BRAMBILLA, Elena (2000), Alle origini del sant'Uffizio. Penitenza, confessione e giustizia spirituale dal Medioevo al XVI secolo, II Mulino, Bolonia.

BRAMBILLA, Elena (2006), La giustizia intollerante. Inquisizioni e tribunali confessionali in Europa (secoli IV-XVIII), Carocci, Roma.

BUNES, Miguel Angel de (1989), La imagen de los musulmanes y del Norte de África en la España de los siglos XVI y XVII, Editorial CSIC, Madrid.

BUONFIGLIO COSTANZO, Giuseppe (1604), Prima [e secundi] parte deII'Historia siciliana, Bonifacio Ciera, Venecia.

CAPPONI, Gino (1845), Catalogo dei manoscritti posseduti dal Marchese Gino Capponi, Coi Tipi della Galileiana, Florencia.

CARALI, P. Paolo (1936), "Soggiorno di Fakhr ad-dīn al-Ma'nī in Toscana, Sicilia e Napoli e la sua visita a Malta (1613-1618)", Annali del Istituto Superiore Orientale di Napoli, $\mathrm{n}^{\circ}$ 4, pp. 15-60.

DURSTELER, Eric (2006), Venetians in Constantinople: Nation, Identity, and Coexistence in the Early Modern Mediterranean, Johns Hopkins University Press, Baltimore.

FABRIS, Antonio (1997), "Hasan 'il veneziano' tra Algeri e Costantinopoli", Quaderni di Studi Arabi, n 15 (suppl.), pp. 51-66.

FIUME, Giovanna (2010), Schiavitù mediterranee: corsari, rinnegati e santi di età moderna, Mondadori, Milán.

FLORISTÁN, José Manuel (1988), Fuentes para la política oriental de los Austrias. La documentación griega del Archivo de Simancas (1571-1621), Universidad de León, León.

FLORISTÁN, José Manuel (2016), "Relación de la empresa de Famagusta (1607)", Archivo de la Frontera, http://www.archivodelafrontera.com/ wp-content/uploads/2016/09/1607-EMPRESA-DE-FAMAGUSTA-JM-Florist\%C3\%Aln.pdf

GARCÍA-ARENAL, Mercedes (2001), Conversions islamiques: identités religieuses en islam méditerranéen, Maisonneuve et Larose, París.

GEMIGNANI, Marco (2003), "The navies of the Medici: The florentine navy 
and the navy of the sacred Military order of saint stephen, 1547-1648", en HATTENDORF, John y UNGER, Richard (eds.), War at Sea in the Middle Ages and the Renaissance, Boydell press, Woodbridge, pp. 169-185.

GIL HERRERA, Jorge y BERNABÉ, Luís F. (2014), "The Moriscos Outside Spain. Routes and Financing", en GARCÍA-ARENAL, Mercedes y WIEGERS, Gerard (eds.), The Expulsion of the Moriscos from Spain: a Mediterranean diaspora, Brill, Leiden, pp. $219-238$.

GONZÁLEZ TALAVERA, Blanca (2011), Presencia y mecenazgo español en la Florencia Medicea: de Cosme I a Fernando I. Tesis Doctoral, Universidad de Granada, Granada.

GONZALEZ-RAYMOND, Anita (1989), La Croix et le Croissant: les inquisiteurs des îles face à l'islam, 1550-1700, Centre national de la recherche scientifique, París.

GORDON, Murray (1987), L'Esclavage dans le monde arabe: Vlle-XXe siècle, Robert Laffont, París.

GRAF, Tobias (2014), "Of half-lives and double-lives: 'Renegades' in the Ottoman Empire and Their Pre-Conversion Ties, ca. 1580-1610", en FIRGES, Pascal et al. (eds.), Well-connected domains, Brill, Leiden, pp. 131-149.

GRAF, Tobias (2017), "Trans-Imperial Nobility: The Case of Carlo Cigala (1556-1631)", en NORTON, Claire (ed.), Conversion and Islam in the Early Modern Mediterranean: The Lure of the Other, Routledge, Londres, pp. 9-29.

GRAF, Tobias (2017), The Sultan's Renegades: Christian-European Converts to Islam and the Making of the Ottoman Elite, Oxford University Press, Oxford.

GÜRKAN, Emrah Safa (2014), "Money or Your Life: The Habsburg Hunt for Uluc Ali", Studia Historica: Historia Moderna, Salamanca, $n^{\circ} 36, \mathrm{pp}$. 121-145.

GÜRKAN, Emrah Safa (2016), "His Bailo's Kapudan: Conversion, Tangled Loyalties and Hasan Veneziano between Istanbul and Venice (15881591)", Journal of Ottoman Studies, $n^{\circ} 48$, pp. 277-319.

HADJIANASTASIS, Marios (2014), "Corsair tactics and lofty ideals: the 1607 Tuscan raid on Cyprus", en WALSH, Michael (ed.), Historic Famagusta: A Millennium in Words and Images, Cambridge Scholars Publishing, Cambridge, pp. 22-36.

HERRERO SÁNCHEZ, Manuel (2001), "Una república mercantil en la órbita de la Monarquía Católica (1528-1684)", en ANATRA, Bruno y MANCONI, Francesco (eds.), Sardegna, Spagna e Stati Italiani nell'Età di Carlo V, Carocci, Roma, pp. 183-200. 
HILL, George (1952), A History of Cyprus: The Ottoman Province, the British Colony, 1571-1948 (Vol. 4), Cambridge University Press, Cambridge. KOLOĞLU, Orhan (2007), "Renegades and the case Uluç/Kiliç Alì", en CANCILA, Rosaria (ed.), Mediterraneo in armi (secc. XV-XVIII), Quaderni di Mediterranea, Palermo, pp. 513-531.

KRSTIĆ, Tijana (2009), "Illuminated by the Light of Islam and the Glory of the Ottoman Sultanate: Self-Narratives of Conversion to Islam in the Age of Confessionalization", Comparative Studies in Society and History, n ${ }^{\circ} 51$, pp. 35-63. KRSTIC, Tijana (2011), Contested Conversions to Islam: narratives of Religious Change in the Early Modern Ottoman Empire, Stanford University Press, Stanford.

KUNT, Metin Ibrahim (1974), "Ethnic-Regional (cins) Solidarity in the Seventeenth-Century Ottoman Establishment", International Journal of Middle East Studies, $n^{\circ}$ 5-3, pp. 233-239.

LEWIS, Bernard (1990), Race and Slavery in the Middle East: an Historical Enquiry, Oxford University Press, Nueva York.

LUBIN, Matthew (2011), Aftermath of War: Cypriot Christians and Mediterranean Geopolitics, 1571-1625. Tesis Doctoral, The University of North Carolina at Chapel Hill, Chapel Hill.

MAS, Albert (1967), Les Turcs dans la littérature espagnole du Siècle d'Or: recherches sur l'évolution d'un thème littéraire, Centre de Recherches Hispaniques, París, Vol. 2.

MESSANA, Maria Sofia (2007), "La 'resistenza' musulmana e i 'martiri' dell'islam: moriscos, schiavi e cristiani rinnegati di fronte all'Inquisizione spagnola di Sicilia", Quaderni storici, n 42-126, pp. 743-772.

MONTICONE, Alberto (1961), Paolo Sarpi, Lettere ai gallicani. Edizione critica, saggio introduttivo e note a cura di Boris Ulianich, Franz Steiner Verlag, Wiesbaden.

MONTUORO, Domenico (2009), "I Cigala, una famiglia feudale tra Genova, Sicilia, Turchia e Calabria", Mediterranea: Richerche Storiche, $\mathrm{n}^{\circ} 6$, pp. 277-302.

OCAKAÇAN, Levent Kaya (2015), "Cigalazade Yusuf Sinan Pasha (C. 1545 1606)", Mediterranea: Richerche Storiche, Palermo, n 12, pp. 325-340.

OLDRATI, Valentina (2015), "Pedro Brea, un genovés en Constantinopla: veinte años de espionaje y contra-espionaje entre Madrid, Nápoles, Génova e Imperio otomano (1578-1596)", en SOLA CASTAÑO, Emilio y VARRIALE, Gennaro (coords.), Detrás de las apariencias: información y espionaje (siglos XVI-XVII), Universidad de Alcalá, Alcalá de Henares, pp. 153-173. 
OLDRATI, Valentina (2018), "Renegades and the Habsburg secret services in the aftermath of Lepanto: Haci Murad and the Algerian threat as a case study", Journal of Iberian and Latin American Studies, n² 24, pp. 7-26.

OLIVA, Gaetano (1907-1908), "Sinan Bassà (Scipione Cicala) celebre rinnegato del secolo XVI: Memorie storico-critiche", Archivio Storico Messinese, Mesina, $\mathrm{n}^{\circ} 8 / 9$, pp. 266-303.

PAPPALARDO, Salvatore (2009), "Ambizione politica, commercio e diplomazia alla fine del XVI secolo: Carlo Cicala", en ZACCARIA, Claudio, ANDREOZZI, Daniele y PANARITI, Loredana (eds.), Acque, terre e spazi dei Mercanti: istituzioni, gerarchie, conflitti e pratiche dello scambio dall'età antica alla modernità, Editreg, Trieste, pp. 141-168.

PRETO, Paolo (2010), I servizi segreti di Venezia: spionaggio e controspionaggio ai tempi della Serenissima, II Saggiatore, Milán.

PRETO, Paolo (2013), Venezia e i Turchi, Viella, Roma.

PROSPERI, Adriano (2011), "Firenze", en PROSPERI, Adriano, LAVENIA, Vincenzo y TEDESCHI, John (coords.). Dizionario storico dell'Inquisizione, Edizioni Normale di Pisa, Pisa, Vol. 2, pp. 605-607.

ROSTAGNO, Lucia (1983), Mi faccio turco: esperienze ed immagini dell'islam nell'Italia moderna, Istituto per l'Oriente C.A. Nallino, Roma.

ROTHMAN, E. Natalie (2012), Brokering Empire: Trans-Imperial Subjects between Venice and Istanbul, Cornell University Press, Ithaca.

SCARAFFIA, Lucetta (1993), Rinnegati: per una storia dell'identità occidentale, Laterza, Roma.

SIEBENHÜNER, Kim (2008), "Conversion, mobility and the Roman Inquisition in Italy Around 1600", Past \& Present, , n² 200-1, pp. 5-35.

SOLA, Emilio (2005), Los que van y los que vienen: información y fronteras en el Mediterráneo clásico del siglo XVI, Universidad de Alcalá, Alcalá de Henares.

SOLA, Emilio (2007), La Conjura de Campanela, Turpin, Madrid.

SOLA, Emilio (2011), Uchali: el calabrés tiñoso o el mito del corsario muladi en la frontera, Ediciones Bellaterra, Barcelona.

SOLA, Emilio y DE LA PEÑA, José (1995), Cervantes y la Berbería: Cervantes, mundo turco-berberisco y servicios secretos en la época de Felipe II, Fondo de Cultura Económica, Madrid.

TÜRKÇELIK, Evrim (2013), "El renegado 'El Cigala' y la política mediterránea", Desperta Ferro. Historia Moderna, n 6, pp. 40-43. 
TÜRKÇELIK, Evrim (2012), Cigalazade Yusuf Sinan Pasha y el Mediterráneo entre 1591-1606. Tesis Doctoral, Universidad Autónoma de Madrid, Madrid.

VARRIALE, Gennaro (2014), Arrivano li Turchi: guerra navale e spionaggio nel Mediterraneo (1532-1582), Città del Silenzio, Novi Ligure.

VITALI, Francesco (2017), I nunzi pontifici nella Firenze di Ferdinando I (1587-1609), Nuova Cultura, Roma. 



\title{
EVOLUCIÓN DE LA POBLACIÓN ESCLAVA A TRAVÉS DE LAS CÉDULAS REALES CONCEDIDAS A LA FAMILIA PONCE DE LEÓN EN EL PUERTO RICO DEL SIGLO XVI
}

\author{
EVOLUTION OF THE SLAVE POPULATION \\ THROUGH THE ROYAL CEDULES GRANTED TO THE \\ PONCE DE LEÓN FAMILY IN THE PUERTO RICO OF \\ THE 16TH CENTURY
}

\author{
TAMARA IÁÑez Ramírez*
}

Universidad de Granada

\section{RESUMEN}

La llegada de los colonizadores a las islas del Caribe fue un hito en la historia. Influyó en la forma en la que percibimos el mundo en la actualidad. La forma en la que la isla de San Juan Bautista (Puerto Rico) fue colonizada ayuda a comprender como se fue modificando el sistema de producción, recayendo una gran parte en la mano de trabajo esclava. Una de las forma de percibirlo es el análisis de las diferentes fuentes archivísticas que hacen mención a que personas eran las encargadas de realizar este trabajo. Siendo una de las familias más importantes la de Ponce de León que junto a otras personalidades sustentaron un modelo esclavista, cuya huella, todavía hoy día, sigue patente.

Palabras clave: Puerto Rico, familia Ponce de León, siglo XVI, esclavitud.

\section{ABSTRACT}

The arrival of the colonizers on the Caribbean islands was a milestone in history. It influenced the way we perceive the world today. The way the island of San Juan Bautista (Puerto Rico) was colonized helps to understand how the production system was modified, with a large part in the slave work. One of the ways of perceiving it is the analysis of the different archival sources that mention which people were in charge of doing this work. One of the most important families being that of Ponce de León who together with other personalities supported a slavery model, whose footprint, even today,

Keywords: Puerto Rico, Ponce de León family, 16th c., Slavery.

*Licenciada en Historia por la Universidad de Granada, graduada en Antropología Social y Cultural por la Universidad de Granda y con un Máster en Arqueología por la Universidad de Granada. 


\section{RESUM}

\section{LA POBLACIÓ ESCLAVA SEGONS LES CÈDULES REALS CONCEDIDES A LA FAMÍLIA PONCE DE LEÓN AL PUERTO RICO DEL SEGLE XVI}

L'arribada dels colonitzadors a les illes del Carib va ser una fita en la història, puix va influir en la forma que percebem el món en l'actualitat. La manera que I'illa de Sant Joan Baptista (Puerto Rico) va ser colonitzada ajuda a comprendre com es va modificar el sistema de producció, recaient una gran part a la mà de treball esclava. Una de les formes de percebre-ho és I'anàlisi de les diferents fonts arxivístiques que esmenten quines persones eren les encarregades de fer aquest treball. Sent una de les famílies més importants la de Ponce de León que junt amb altres personalitats sustentaren un model esclavista $\mathrm{i}$ han deixat una petjada que, avui dia, segueix patent.

Paraules clau: Puerto Rico, família Ponce de León, segle XVI, esclavitud. 


\section{INTRODUCCIÓN}

La isla de Puerto Rico durante el siglo XVI tiene una población compleja que va evolucionando a lo largo de las primeras décadas. Este artículo se va a centrar en una parte muy concreta: la población esclava. Conformada ya sea por personas que fueron sometidas provenientes de la isla de San Juan, de otras islas del Caribe, traídas desde la Península lbérica o desde el continente africano. Para hacer posible este artículo he llevado a cabo una revisión bibliográfica y poder así abordar esta cuestión en particular. Añadiendo a esto el análisis y estudio de una serie de documentos archivísticos que pueden dar una serie de pautas sobre cómo evolucionó el tipo de personas que engrosaban esta parte de la población de la isla. Una de las principales problemáticas al abordar este tema, y que hay que tener en cuenta, es que en muy poco tiempo la forma en la que se nutren de población esclava va cambiando de forma muy rápida. Por lo que responder a la cuestión del por qué ocurre es complicada. Ya que la respuesta no es única, sino que pueden existir multitud de ellas. Otra de las cuestiones a responder es si en este proceso de cambio se puede vislumbrar el porqué del inicio de un tráfico esclavista que se nutría del África subsahariana y que se convirtió en un tráfico global.

Todas estas cuestiones no se pueden abordar si no se tiene cuenta, desde un primer momento, la importancia de la esclavitud como un sistema de producción a lo largo del siglo XVI. Siendo un sistema, que aunque estaba en un momento de decadencia en la Península Ibérica, se había trasladado a las islas del Caribe cómo único método plausible para satisfacer las necesidades productivas. Lo importante de esta afirmación, es que la esclavitud, tanto en España como en Europa, era una realidad. Este axioma nos ayuda a colocarnos en un contexto, tanto histórico como social, político y 
económico que se aleja de nuestra realidad actual. Lo que nos ayuda a abordarlo con cierta perspectiva histórica necesaria para no caer en prejuicios morales y éticos.

Otro de los aspectos a tener en cuenta para comprender la importancia de Puerto Rico en la historia de la esclavitud en el Caribe, es su posición en dicho mar. Lo que condiciona sobre manera la historia de su colonización. Para atisbar este proceso he decidido centrarme en una familia que tuvo una gran relevancia histórica en la colonización de la isla de Puerto Rico, la de Ponce de León. Teniendo como epicentro de este análisis las diferentes Cédulas Reales que se concedieron a lo largo de los años, dónde se hace hincapié en las encomiendas relacionadas con la esclavitud, ya sea sobre la población autóctona de la isla de San Juan, de otras islas del Caribe, de personas traídas de la Península lbérica o de África.

\section{Esclavitud y sistema esclavista duRante la Edad Moderna en España}

Lo primero que voy a abordar es cual fue la importancia de la esclavitud en España. Algo esencial para poder comprender como este sistema tuvo una gran acogida, siendo pensado como el único para obtener una producción de la isla. Lo que se implementa en la isla no es otra cosa que el reflejo de lo que había en Europa a lo largo de la Edad Moderna. La esclavitud era un sistema normalizado dentro del marco europeo, así como en España. Según los prejuicios actuales se hace imposible aceptar la idea de que la esclavitud era una realidad en el siglo XVI. Y lo más importante, que era un sistema reconocido de forma generalizada, el cual se percibía por parte de la sociedad, el Estado y la Iglesia Católica como algo valido y aceptable.' Un sistema que se convirtió en algo imprescindible para los Reinos de Castilla y Aragón de la Península lbérica en el siglo XVI, un elemento para controlar a la población, para implementar medidas civilizadoras, evangelizadoras y productivas. ${ }^{2}$ Ya no solo en la Península lbérica sino también en las islas del Caribe.

Para llegar a entender la importancia de la mano de obra esclava en los Reinos de la Península Ibérica, sobre todo en el Reino de Castilla, hay que tener en cuenta que, aunque la economía no descansa de forma total en

1 MARTÍN CASARES, Aurelia. (2000). La esclavitud en la Granada del Siglo XVI. Universidad de Granad, Granada.

2 BUGANZA, Jacob (2006), "La Otredad o Alteridad en el Descubrimiento de América y la Vigencia de la Utopía Lascasiana", Razón y Palabra, n 54. 
la mano de trabajo esclava, es decir, no podemos considerarla como una "sociedad esclavista", sí tiene una gran importancia. ${ }^{3}$ Es decir, el mundo moderno incipiente de finales del siglo XV, tiene una economía imposible de subsistir sin dichas personas esclavas. ${ }^{4}$ Es por ello que existe una necesidad imperante por parte de estos reinos cristianos de hacerse con esclavos y esclavas, ya que eran un elemento necesario para que el sistema de producción no colapsase. ${ }^{5} \mathrm{Y}$ aunque era un sistema que estaba en vías de desaparecer, la llegada de los reinos cristianos a las islas del Caribe lo refuerza. ${ }^{6}$ En un primer momento, durante la Edad Media, las principales personas esclavizadas son de la propia Península lbérica. Personas que eran capturadas mediante las guerras y razias entre los reinos pertenecientes a la fe cristiana y fe musulmana. Esto dejó de producirse ya que en 1492 no existían tierras bajo el dominio musulmán. También se benefician los reinos cristianos de las gentes de las islas Canarias, los guanches, algo que al poco tiempo se prohíbe ya que eran personas que habían sido evangelizadas, y por las revueltas y rebeliones en las Alpujarras, en Granada, entre 1568 y 1570 . También existía un comercio con Italia que suministraba personas del Mar Negro. Algo que cambia a finales del siglo XV ya que pierde el control de esta zona en beneficio del Imperio Ruso.?

En el imaginario colectivo parece imperar en la creencia popular que la esclavitud en la Península lbérica no existía y que con la llegada de la modernidad se presupone la extinción de la esclavitud como sistema productivo. Cuando la esclavitud fue un sistema que estuvo vivo hasta finales del siglo XIX. Un sistema que permitió la colonización efectiva de las tierras del Caribe y de la tierra firme de America.

Como constancia de ello son la multitud de artículos, libros y estudios que se han centrado en la esclavitud tanto en la Península Ibérica como en otras partes de Europa como por ejemplo Francia e Italia durante la Edad Moderna y hasta siglo XIX. ${ }^{8}$

3 MARTÍN CASARES, La esclavitud en la Granada del Siglo XVI.

4 MINGORANCE, José Antonio y ABRIL, José María, (2013), La esclavitud en la Baja Edad Media. Jerez de la Frontera. 1392-1550, PeripeciasLibros, Madrid.

5 FRANCO SILVA, Alfonso, (1992), Esclavitud en Andalucía (1450-1550), Universidad de Granada, Granada.

6 PHILLIPS, William. D. (1989), La esclavitud desde la época romana hasta los inicios del comercio transatlántico. Siglo XXI, Madrid.

7 PHILLIPS, La esclavitud desde la época romana.

8 FRANCO SILVA, Alfonso, (1995), "La esclavitud en la península ibérica a finales del Medievo. Estado de la cuestión y orientaciones bibliográficas", Medievalismo. Boletín de La Sociedad Española de Estudios Medievales, n6, pp. 201-210. 


\section{Puerto Rico: contexto geográfico e histórico}

El lugar en el que centra esta investigación es la isla de Puerto Rico, situada en el mar Caribe. La más pequeña de las Antillas mayores, y en una de las primeras islas en las que llegaron los barcos de los primeros colonizadores. Esta posición geográfica influirá de forma contundente en el devenir histórico de dicha isla, no solo en su pasado, sino en su presente más inmediato, ya que es la isla que da entrada al mar Caribe, y al resto del continente Americano.

La isla de Borinquen, nombre con la que se identificaba a la isla de Puerto Rico en época taína, antes de la llegada de los pobladores españoles, fue descubierta por Colón en su segundo viaje en 1493, más concretamente el 25 de septiembre. Esta expedición se dirigía a La Española donde había abundante oro y riquezas. A esta isla la bautizaron con el nombre de San Juan Bautista. ${ }^{9}$ Y no fue hasta casi 15 años después cuando se produjo la colonización de la isla. ${ }^{10} \mathrm{El}$ momento en el cual a Colón ya se le habían retirado sus derechos sobre la colonización y explotación del Nuevo Mundo. La persona encargada de llevar a cabo la colonización efectiva de la isla fue Juan Ponce de León, en el año 1508 con el beneplácito de los Reyes Católicos y el gobernador general Frey Nicolás Ovando. Para hacer efectivo el control de la isla, Juan Ponce de León se puso en contacto con los caciques de la isla. A estos caciques se les concedió tierras e indios en propiedad para que las produjesen.

Es así como comenzó un sistema muy parecido al que existía en ese momento en la isla de La Española. La población que habitaba en estas islas, junto con las tierras, se repartieron entre los caciques autóctonos de la isla, y los colonizadores, entre los que se contaba Juan Ponce de León. Esta poblacion autóctona trabajaba de forma forzosa en las minas de oro para el beneficio de la Corona y en las tierras que se repartieron entre los colonizadores y caciques. ${ }^{11}$

La población de la que se nutrió el sistema esclavista en la isla de San Juan Bautista fue cambiando a lo largo de los años de forma rápida y constante, sobre todo en las primeras décadas del siglo XVI. Este sistema se sustentó de personas tanto de dentro como de fuera de la isla.

9 PICÓ, Fernando, (1990), Historia general de Puerto Rico, Ediciones Huracán, Río Piedras.

10 DÍAZ SOLER, Luis Manuel, (1950), Historia de la esclavitud negra en Puerto Rico (1493-1890), Lousiana State University Press / Universidad de Puerto Rico, San Juan.

11 PICÓ, Historia general de Puerto Rico. 


\section{Evolución del sistema esclavista en la isla de San Juan Bautista}

En la isla de San Juan Bautista se puede apreciar cómo ha ido cambiando en el siglo XVI la procedencia de las personas que eran esclavizadas, o que eran utilizadas como mano de obra que sustentaba este sistema esclavista. Lo que nos va dando información del devenir histórico de la propia isla y de los reinos peninsulares en cuanto a conflictos como a relaciones políticas y religiosas.

\section{Población taína y caribes}

En estas dos primeras décadas la población que se utilizó para sostener la producción de la isla de San Juan Bautista fueron tanto los taínos, población autóctona de la isla, como los caribes, que habitaban las islas del este del Caribe, así como las costas de Venezuela. Se estima, según estudios llevados a cabo, que había entre los años 1508 y 1520 unos 60.000 y 125.000 indios taínos y caribes. ${ }^{12}$

La población que vive en la isla de Puerto Rico es la denominada como taína, diferenciándola de los caribes. Rouse pone sobre la mesa que estos dos términos separan a los taínos y los caribes entre las diferentes islas del Caribe. ${ }^{13}$ Los taínos serían aquellos que habitaban en las Antillas mayores, mientras que los caribes se encontrarían en las Antillas menores y costas de Venezuela. También se impondría una creencia entre estas dos poblaciones, y es considerar la población taína más sumisa y fácil de someter. Mientras tanto, los caribes serían aquellos considerados los más agresivos, caníbales y menos propensos a dejarse subyugar por las autoridades colonizadoras. Era una forma de diferenciar entre aquellos que eran más fáciles de controlar y aquellos que eran rebeldes y luchaban por su libertad. ${ }^{14}$ En estos primeros años de contacto, se percibe una disminución de la población autóctona de la isla. Esto se debe a varias causas, una de ellas es por la multitud de enfermedades que traen los colonizadores no siendo inmune esta población y por tanto sucumbiendo a la muerte. Otra de las causas es la insuficiencia en la alimentación, que llevó a las poblaciones

12 MOSCOSO, Francisco (2005), "Población del siglo XVI", en Tras las huellas del hombre y la mujer negros en la historia de Puerto Rico. Antología de lecturas, Departamento de educación de Puerto Rico, San Juan, , (pp. 262-264).

13 ROUSE, Irving, (1992). The Tainos: rise \& decline of the people who greeted Columbus, New Haven, Yale University Press.

14 WHITEHEAD, Neil. L. (1995), "Ethnic plurality and cultural continuity in the native Caribbean: Remarks and uncertainties as to data and theory", Wolves from the Sea, pp. 91-111. 
autóctonas de la isla a menguar de forma rápida. Son varios los autores que opinan que a esto hay que añadir la represión a la que fueron objeto por parte de los colonos. ${ }^{15}$ Aunque los documentos que hacen referencia a una represión explícita contra las poblaciones de las islas del Caribe, únicamente hacen mención a los caribes. El documento que muestro a continuación en el que se hace referencia a como se pone a Juan Ponce de León a la orden de una armada para reprimir las acciones violentas que están llevando a cabo los caribes. ${ }^{16}$

"Nuestros oficiales de la Casa de Contratación de las Indias, que residís en la ciudad de Sevilla: Ya sabéis, como otras veces os he escrito, la mucha necesidad que hay que la armada que hemos mandado hacer contra los caribes vaya lo más presto que ser pueda, y porque mandamos ir por capitán de ella a Juan Ponce de León $[. . .]^{\prime \prime} .^{17}$

Aquí se hace referencia a cómo la población que se ha revelado contra las autoridades coloniales son los caribes. Esto, como ya he mencionado con anterioridad, puede llevar a error a la hora de saber que poblacion y que islas son las que se han rebelado. Al hablar de caribes, parece que no se hace referencia a los habitantes de la isla de Puerto Rico, y que eran poblaciones más agresivas que no tenían nada que ver con los taínos. Un pueblo que luchó con fuerza y de forma feroz para echar de sus tierras a los invasores y opresores. Pero también se ha expuesto que estos términos pueden ser vistos como una construcción ideológica, entorno a la creencia de que los más sumisos y pasivos fuesen los taínos, mientras que los más agresivos se les denominaba como caribes. Una construcción académica y social para dar una respuesta al por qué unas poblaciones eran fáciles de someter mientras que otras eran insubordinados y rebeldes. ${ }^{18}$ Por lo que, a lo mejor, estas revueltas se produjeron en la isla de Borinquen pero se asumió por las autoridades coloniales que fuereon producidas por las poblaciones caribes y dando por imposible que fuesen los taínos los causantes de estas escaramuzas.

15 DÍAZ SOLER, Luis María. (1953). Historia de la esclavitud en Puerto Rico, Editorial de la Universidad de Puerto Rico, San Juan.

16 PICÓ, Historia general de Puerto Rico.

17 Real Cédula, (1531), Archivo General de Indias (AGI), Santo Domingo, 2280, L. 1, F.90V-91R.

18 ROUSE, The Tainos: rise \& decline of the people who greeted Columbus. 
Existen varios documentos en los que se hace referencia a los caribes como una población difícil de someter y agresivos. En estos documentos se hace referencia a la guerra que se estaba llevando contra estas poblaciones y como a través de su venta se estaba financiando estas contiendas.

"De los caribes que se cautivaren de buena guerra habéis de enviar a la isla Española a los nuestros oficiales, que en ella residen, las dos tercias partes dellos, para que los vendan en nuestro nombre, y de los que ellos hubiere, sirve para ayuda a gastos de la dicha armada, y la otra tercia parte dellos habéis de repartir entre la gente que con vos fuere en la dicha armada, para que los vendan y se aprovechen dellos como de cosa suya, porque con darles la tercia parte de los esclavos que hubieren, se excusen el sueldo que se haya de dar $[\ldots]^{\prime \prime} .^{19}$

Este es un ejemplo perfecto de que estos indios caribes eran capturados en la guerra, se vendían como esclavos y se entregaban como pago a la gente que participaba y guerreaba bajo el estandarte de la Corona de Castilla. Durante los primeros años del siglo XVI estos se convirtieron en la principal mano de obra esclava, para sacar de la isla el poco oro que había. Junto a estos caribes, tal y como son nombrados en los documentos históricos, también se pueden encontrar a los taínos. Poblacion de la isla de Puerto Rico, y que no podían ser tratados como esclavos ya que en los primeros años de la colonización se dejó estipulado que estas personas no podían ser tratadas como esclavas. Por el contrario solo sufrirían esta falta de libertad durante un periodo de tiempo determinado.

Una de las primeras medidas que se llevaron a cabo fueron los Repartimientos de Indios, mediante los cuales se repartían a los indios siendo los principales beneficiarios tanto colonos como caciques naturales de la isla.

"Don Fernando, etc., por cuanto visto por el Concejo los privilegios que yo y la serenísima Reina, $D^{a}$ Isabel, mi mujer [...] hebemos proveído de mandar enviar personas para que de nuevo hagan el repartimiento en la dicha isla de San Juan, porque el que estaba hecho della no es tan igual ni justo como a nuestro servicio y al bien y provecho de los vecinos y moradores y otras personas de la dicha isla convenía 
[...] hayais información por todas partes y maneras que mejor pudiereis saber qué caciques e indios y naborios hay en dicha isla de San Juan para poder repartir $[\ldots]^{\prime \prime}{ }^{20}$

En este fragmento de un texto escrito en el año 1514 podemos observar cómo estos repartimientos de indios se hacían entre los vecinos que así lo merecen de la isla a Juan Ponce de León. Pero existe un aspecto que llama poderosamente la atención, un concepto, el cual hace referencia a la población india de la isla de San Juan, naboría. Estos naboríos hacen alusión al repartimiento de los indios entre los vecinos de la isla, pero con la particularidad de que estos indios solo estarían bajo su servicio durante un periodo determinado de tiempo. Pasado estos años estas personas debían ser liberadas. Es por tanto que no pueden ser considerados como población esclava en el más estricto sentido de la palabra. Eran personas que estaban sometidas durante un periodo de tiempo concretado con anterioridad.

"Adelantado Juan Ponce de León, nuestro capitán de la isla de San Juan,: Vi o que escribistes, que en las islas de los caribes hay muchos indios e indias naturales de la dicha isla de San Juan, que algunos han llevado cautivos los dichos caribes, y otros de su voluntad que han ido con ellos, y porque yendo vos, como placiendo a Nuestro Señor habéis de ir con nuestra armada a hacer guerra a los dichos caribes, creéis que muchos de los indios se vendrán de su voluntad a vos [...] mandase declarar para si serían libres o cautivos, lo cual visto parece que viniéndose los dichos indios de su voluntad a vos, y a la gente que con vos va en esta armada a nuestro ser vicio y obediencia, los recibáis y llevéis a la dicha isla de San Juan, y allí se encomienden a los vecinos por naborías se casa, como las otras naborías de la dicha isla [...]". ${ }^{21}$

Esta no es más que una muestra de que los caribes hacían presos a muchos autóctonos de la isla de San Juan, los taínos. Y es por ello que ven en estas personas, que pudieron haber sido objeto de sometimiento por parte de 
las poblaciones caribes, como poblaciones que accederían de buen grado a ir con las tropas castellanas y hacer la guerra contra los caribes, como un enemigo común. Siendo llevados de nuevo a San Juan donde serían repartidos en las diferentes casas.

Pero no solo los caribes hicieron la guerra contra los colonos, también hay documentos donde se especifica que las propias gentes de San Juan se rebelaron contra las tropas colonizadoras. Según algunos documentos, como veremos a continuación de 1512, se hace mención a este hecho, haciendo mención también que las gentes autóctonas de la isla estaban siendo esclavizadas. No con un carácter temporal, sino de por vida, algo que no estaba contemplado como legal.

"Don Fernando [...] tenemos mandado que por el tiempo que nuestra voluntad fuese todos los indios que fueren tomados de buena guerra en la isla de San Juan por los vecinos y otras personas della, sean y queden por esclavos de los que los tomaren, y porque yo he sido informado que en lo susodicho se hacen muchos fraudes $y$ tienen por esclavos otros indios diciendo, que son tomados de buena guerra y dellos con su inocencia no saben alegar su derecho [...] por la presente, es mi merced y voluntad y mando que todos los indios que desde el día que ésta, mi carta, fuere pregnada en la dicha isla de San Juan en adelante fueren tomados de buena guerra en la dicha Isla por los vecinos y otras cualquiera personas della, sean naborías de los que los tomaren y los tengan y los sirvan dellos [...] que no sean esclavos $[\ldots]^{\prime \prime} .^{22}$

En este fragmento se puede leer que los vecinos de la isla si estaban tomando como esclavos a los indios pero se deja dicho que eso no era legal. Por lo que se deja dicho que a partir del momento de la llegada esta carta los indios capturados en la buena guerra no podían ser esclavos, sino que por el contrario, debían ejercer en las naborías para el beneficio de los vecinos y vecinas de la isla.

En las primeras décadas de la colonización, ya se puede observar, mediante el análisis de los diferentes documentos que nos hemos encontrado, 
que la población autóctona de estas islas iba teniendo un trato especial y que existían debates en torno a la posibilidad de que fuese posible evangelizarlos y que de esta forma formasen parte de la Iglesia Católica. Es por esta razón que el rey Fernando el Católico en 1513 redacta una serie de ordenanzas para el buen trato de los indios, para ser tratados como los y las españolas que vivían en la isla: ${ }^{23}$

"Primeramente, ordenamos y mandamos que por cuanto es nuestra determinación de mudar dichos indios y hacerles estancias junto con la de los españoles [...]"

"Asimismo ordenamos y mandamos que el vecino a quien encomendare los dichos indios, sea obligado a les tener hecha una casa para la iglesia juntamente con la hacienda [...] en la cual dicha iglesia ponga imágenes de Nuestra Señora y una campanilla para los llamar a rezar [...] todos juntos decir el Ave Maria y el Pater Noster y el Credo y Salve Regina [...]"

"Ordenamos y mandamos que cada uno que tuviere cincuenta indios o donde arriba encomendados, sean obligados a hacer mostrar un muchacho, el que más hábil dellos les pareciere, a leer y a escribir las cosas de nuestra fe para que aquellos muestren después a dichos indios $[\ldots]^{\prime \prime}$

Esto es solo una pequeña muestra de una serie de reglamentos que tiene un total de 35 leyes en las cuales se hace un especial hincapié en la necesidad de evangelizar a estas poblaciones, para expandir la fe católica. También se menciona la necesidad de enseñar a escribir y leer, ya que es esencial conocer la lengua para que esta evangelización sea efectiva. Se hace una mención especial a la alimentación que se les debía dar así como al alojamiento mientras están bajo la encomienda, ya que son una responsabilidad directa del encomendero. Especificando que estos indios que están en encomiendas no solo pueden trabajar en las tierras de los encomenderos, sino que una tercera parte de estos indios deben trabajar en las minas del reino. Es definitiva un compendio de leyes en las cueles se especifica cómo deben ser tratados estos indios y como se debe hacer uso de ellos. 
Además existen otros ejemplos de que los colonos tuvieron una relación muy cercana a la población indígena de la isla. En la Real Cédula a Don Diego Colón a los jueces de la Isla Española, se le da licencia a cualquier persona natural de los reinos de Castilla, residente en la isla, para que puedan casarse con indias naturales de aquella. ${ }^{24}$ Algo que solo se puede entender si se tiene en cuenta que la población mayoritaria que viajaba al "Nuevo Mundo" eran hombres y que las mujeres que viajan lo hacían junto a sus maridos o eran de familias pudientes. Esta posibilidad de casarse con mujeres autóctonas de la isla nos demuestra que había una cercanía entre ambas poblaciones.

Por lo tanto, entre la disminución de la población india de la isla por los diversos motivos que se han mencionado con anterioridad se debe añadir que se estaban llevando a cabo leyes que protegían y equiparaban a la población india con los venidos de la Península lbérica, la necesidad de un suministro de mano de obra esclava era cada vez más imperante.

\section{Población esclava traída de la Península Ibérica a la isla de San Juan Bautista}

En estas primeras décadas, en la isla de San Juan, también podemos encontrarnos esclavos y esclavas llevados desde la Península lbérica a través de licencias. La esclavitud durante el siglo XVI en la isla de San Juan tuvo un recorrido diferente al que se supone que existía en siglos posteriores. El tráfico negrero no estaba implementado como el sistema predilecto para abastecer a las islas del Caribe de mano de obra esclava, sino que esto se llevaría a cabo más adelante. ${ }^{25}$

En diferentes documentos encontrados en el Archivo General de Indias sobre los esclavos y esclavas que fueron llevadas a San Juan por Juan Ponce de León entre 1511 y 1514 se pueden observar varios aspectos que nos ayudan a comprender qué condiciones se necesitaban que tuviesen estos esclavos y esclavas para pasar a las islas durante estas primeras décadas.

Después de analizar los documentos que he encontrado se hace patente que existen una serie de condiciones que tienen que cumplir estas personas esclavizadas para poder ser llevadas a tierras del Nuevo Mundo. Poniendo 
de este modo, en las primeras décadas del siglo XVI, limite al movimiento de esclavos y esclavas entre continentes ya que lo que se buscaba no era mano de trabajo.

Uno de los requisitos indispensables que debían tener estas personas esclavizadas era la de ser cristianos. Debían ser personas cristianizadas y que procediesen de la Península lbérica, es decir, que hubiesen nacido o que hubiesen vivido en la Península. Esta es una forma de acreditar que todas las personas que habitaban en la isla eran de la religión católica, sin temor a que se extendiese por la isla religiones que no eran cercanas a la Corona.

Un ejemplo de esto lo encontramos en una licencia de 1514 que se le concede a Juan Ponce de León para pasar esclavos de España a la isla de San Juan. En esta licencia se especifica que estas personas son dos hombres y dos mujeres, que viven como cristianos desde hace cuatro años, lo que significa que no nacieron con esta religión sino que se convirtieron ya sea por la fuerza o por voluntad propia. Esto nos puede hacer pensar que fueron llevados desde algún lugar fuera de la Península lbérica en el que no se profesase la religión católica y que hubiesen sido comprados y vendidos en los puertos españoles o, por el contrario, que sí hubiesen nacido en la Península y que por tanto fusen personas moriscas, que tras la Conquista de Granada, se les obligase a convertirse al cristianismo y fuesen capturados como esclavos. ${ }^{26}$

Otro ejemplo de ello es la licencia de esclavos que se le da a Juan Ponce de León en 1512 en la cual se especifica: "Juan Ponce de León puede pasar tres esclavos y tres esclavas cristianos a la isla de La Española" ${ }^{27}$ En esta licencia en el que se especifica que estos esclavos van a servir a su hijo Luis Ponce de León, también se deja constancia de que estas personas son cristianas, parece ser un requisito indispensable para dar la licencia necesaria para transportar a estas personas al "Nuevo Mundo".

El siguiente aspecto que se destaca y parece ser de gran importancia para la concesión de la licencia, es que estas personas esclavas sean para el servicio personal del dueño y la dueña. Parece que durante las primeras décadas del siglo XVI se estaba limitando el número de esclavos y esclavas externos a la isla, imponiéndoles la necesidad a los amos de que estas personas esclavas estuviesen destinados a un servicio personal, dedicados 
al hogar, al servicio más cercano a sus dueños y propietarios. No beneficiándose de su venta en la isla.

En varios documentos se expresa y se jura, que los esclavos y esclavas que se llevan a la isla son para el servicio personal de Juan Ponce de León o de su hijo Luis Ponce de León. En una Real Cédula se deja constancia de que Pedro Moreno, en nombre de Juan Ponce de León, pasa a la isla una esclava para servicio de la casa de éste, dando juramento de que es cristiana y de que se la entregará a éste cuando llegue a puerto. Esta Real Cedula es de $1511 .^{28}$

Parece que mediante los repartimientos y las naborías son los indios taínos y caribes los que hacen un trabajo más duro en la isla de San Juan, ya que trabajan en las minas sacando el poco oro que había y en las tierras. El tráfico de esclavos que había de fuera del Caribe era mínimo y se hacía con cuidado, eligiendo las personas que iban a entrar y el trabajo que iban a realizar. A esto se le añade que el traer esclavos y esclavas de la Península debía ser costoso, ya no solo por el viaje, y por la dificualtad que suponía que concediesen las licencias necesarias. Sino por el hecho de que la población esclava en la Península no es muy numerosa. Estas personas esclavas, en la isla de San Juan, se puede presumir que su tenencia se consideraba un bien para privilegiados y para gente con cierto nivel adquisitivo y estatus.

En los documentos que se han podido analizar no existe una diferencia en el sexo entre las personas que eran llevadas a las islas desde la Península Ibérica como esclavos. Había tanto hombres como mujeres, no concediendo predilección por ninguno de los sexos. Tanto hombres como mujeres eran llevados a la isla como esclavos. Ambos eran productivos dentro del sistema esclavista de principios del siglo XVI, ya sea por su oficio o por sus cualidades.

Otro de los aspectos curiosos en estas licencias es que no especifica el color de la piel, parece que no es relevante que tenga la piel negra o blanca, ya que en los documentos que he analizado no se menciona en ningún caso el color de piel de estas personas. No es hasta unas décadas después cuando se va mencionado en varios documentos el color de la piel entre las personas que se traen a la isla.

28 Licencia de pase de esclava a Juan Ponce, (1511), AGI, Indiferente, 418,L.3,F.191V(1). 


\section{Comienzo del tráfico negrero}

Un periodo que podríamos denominar de transición y se puede percibir a través del análisis de la población que existe en la década de los treinta durante el siglo XVI. Comienza a percibirse una masa de población esclava más heterogénea y diversa. Para ello se ha analizado el censo realizado por el Gobernador Francisco Manuel de Lando entre los años 1530 y 1531. El recuento final eran de 332 españoles, indios encomendados 497, indios esclavos 1527 y esclavos negros 2077, además de esclavos cautivos 1030 personas. ${ }^{29}$

Con el análisis de este censo (gráfico 1) podemos ver que existe en la isla de San Juan dos ciudades con una importancia mayor que el resto, San Juan y San Germán. En ambas ciudades los vecinos libres y colonos, es decir, que no eran naturales de la isla y que su procedencia se puede presumir era del Viejo Mundo, más concretamente de la Península lbérica, eran una mínima parte del total de la población de la isla.

Lo que más llama la atención de este censo (gráfico 2) es que hay cada vez más negros y negras esclavizadas que gentes autóctonas del lugar, aunque en estos primeros momentos el número es muy parecido. Esto muestra que las necesidades de los colonos va cambiando y esto puede deberse a varios motivos. Uno de los cuales pude ser que los indios, tanto taínos como caribes, habían sido diezmados, ya sea por las enfermedades que sufrieron tras el contacto con los españoles, una insuficiencia alimentaria - por las guerras que se llevaron a cabo entre los caribes y los colonos. ${ }^{30}$ Ocasionando una necesidad de mano de obra que no podía satisfacerse con únicamente los esclavos y esclavas que eran traídos desde la Península Ibérica. También las plantaciones eran cada vez mayores y por tanto se necesitaba una mano de obra masiva para trabajar en las tierras y en las minas que todavía estaban activas.

Pero otro de los motivos es que se alzaron voces en contra de la esclavización de las poblaciones autóctonas de las islas caribeñas y de tierra firme del continente americano. Con la instauración de la Iglesia Católica en las islas del Caribe, y más particularmente con la Orden de los Dominicos,

29 WATLINGTON, Francisco, (2013), "La tatarabuela: el siglo XVI en Puerto Rico", Revista de Ciencias Sociales, $\mathrm{n}^{\circ}$ 26, pp. 14-29.

30 PICÓ, Historia general de Puerto Rico. 


\section{Censo Gobernador Francisco Manuel de Lando (1530-1531)}

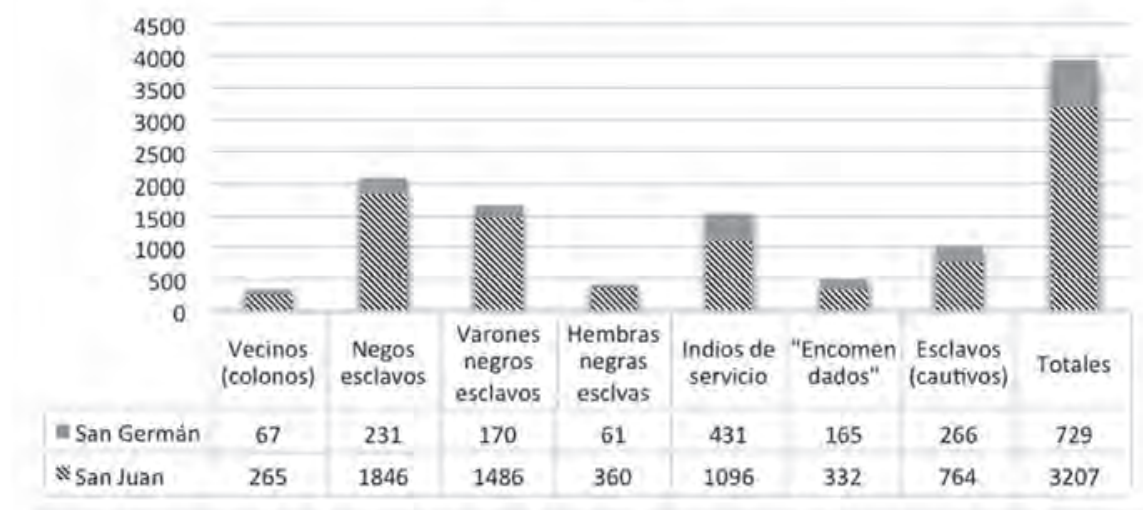

Gráfico 1. Elaboración propia a partir de los datos obtenidos del censo del Gobernador Francisco Manuel de Lando (noviembre de 1530 y marzo de 1531) (WATLINGTON, 2013).

\section{Total de personas en el Censo Gobernador Francisco Manuel de Lando (1530-1531)}

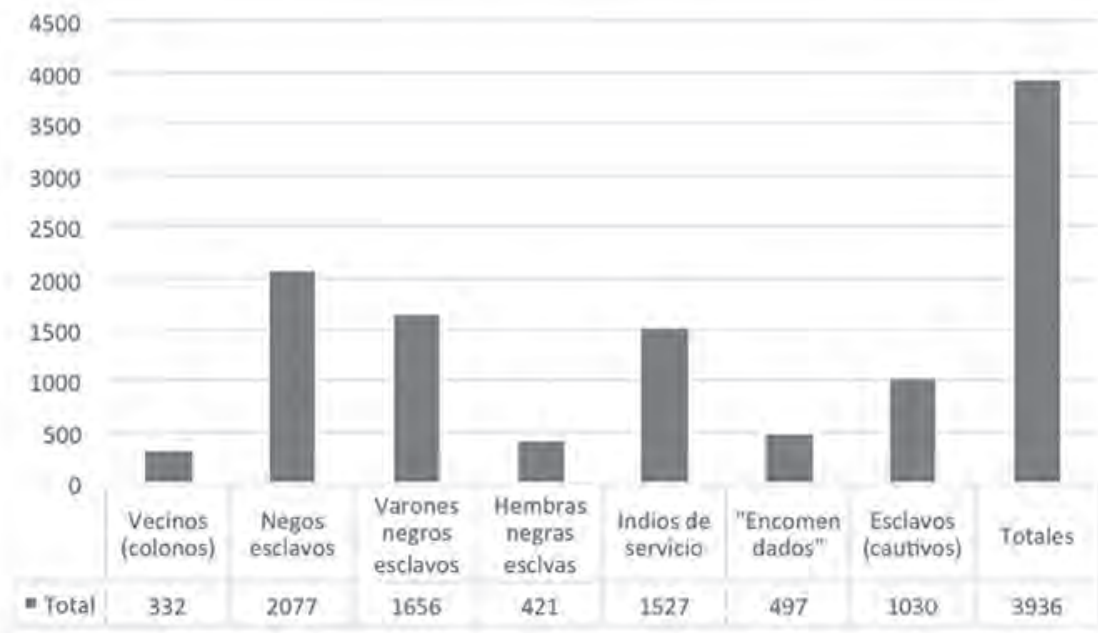

Gráfico 2. Elaboración propia a partir de los datos obtenidos del censo del Gobernador Francisco Manuel de Lando (noviembre de 1530 y marzo de 1531) (WATLINGTON, 2013). 
se produjo una lucha por hacer que las poblaciones de indios de las islas caribeñas, tanto taínas como caribes, fuesen liberadas ya que estaban diezmadas. Aunque el sistema esclavista para algunos juristas y teólogos fuese en contra del derecho a la libertad de las personas, la lglesia y el Estado europeos no se pudieron negar a legislar sobre un sistema productivo instaurado y naturalizado. ${ }^{31} \mathrm{El}$ más mediático de estos debates fue el que se produjo en la Escuela de Salamanca en 1552. Cabe destacar que este movimiento no va contra la esclavización ni contra el Estado, sino que se debatía sobre quienes debían ser sometidos y quienes no, para suplir y abastecer de mano de trabajo esclava a ese sistema. ${ }^{32}$ Entre los que participaron en este debate estaban Fray Bartolomé de las Casas a favor de la no esclavización de las poblaciones amerindias y Juan Ginés de Sepúlveda, teólogo y doctor a favor de la esclavización de estas poblaciones. Bartolomé de las Casas, expone en uno de sus escritos: ${ }^{33}$

"En cuanto a los indios, porque están muy destruidos y muy flacos [...] no an dejado los cripstianos sino ocho o nueve mil [...] hecer mercedes en serbirse dellos como de libres y vasallos suyos [...] haga merced a los cristianos, que agora están en las yslas, que pueden tener cada uno dos esclavos negros y dos negras $[\ldots]^{\prime \prime 34}$

Es en este documento se pone de manifiesto que la esclavitud de la población indígena de las islas del Caribe debería estar prohibida. Aunque no es menos cierto que estas poblaciones siguieron trabajando como casi-esclavos para los conquistadores durante un periodo de tiempo bajo condiciones infrahumanas, lo que se conocía como naboríos o naborías. Y esto se debe, principalmente a que la esclavitud no es algo de lo que se pueda prescindir. Por lo tanto estas naborías son una solución a esa deficiencia de mano de trabajo. Esta necesidad les llevó a la conclusión que la mejor forma de suplirla era mediante la traída de personas desde continente africano.

31 DÍAZ SOlER, Historia de la esclavitud negra en Puerto Rico.

32 MINGORANCE y ABRIL, La esclavitud en la Baja Edad Media.

33 COLL, Cayetano, (1972), Historia de la esclavitud en Puerto Rico: (información y documentos). Compilación de Isabel Cuchi Coll. Sociedad de Autores Puertorriqueños, San Juan de Puerto Rico.

34 Fray Bartolomé de las Casas: apaciguamiento de indios. (1516). AGI, 252,R.2 
La introducción de población esclava proveniente directamente de África y en mayor cantidad que anteriormente se comenzó a producir a partir de la década de 1520. Este tráfico negrero se llevó a cabo por la falta de mano de obra indígena esclava y por el creciente sentimiento de proteger a las poblaciones indígenas isleñas que habitaban en el Caribe. ${ }^{35}$

Todo esto provoca que la forma en la que se introducen personas esclavizadas a la isla de San Juan, y al Caribe en general, va cambiando, y se hace evidente cuando encontramos varios documentos en los que la descripción de las personas que se traen va variando en comparación con las primeras que ya habíamos mencionado y encontrados de la primera década del siglo XVI. La Cedula Real de 1534 concedida a Cristóbal Ponce de León podemos leer: "El Rey, para Don Cristóbal Ponce de León de veinte esclavos negros". ${ }^{36}$ En este documento no se especifica el sexo de las personas que se van a llevar como esclavos a la isla, que tipo de trabajo van a realizar o si están cristianizados. Eso comienza a no ser importante para las autoridades que regulan este tráfico esclavista, la Casa de Contratación. En lo que si se especifica es el color de la piel, se dice que son negros. Es el comienzo de lo que se denominaría el tráfico negrero. Personas que son capturadas en África con el único propósito de servir como esclavos y esclavas.

Otro documento que hace referencia a la traída de esclavos negros a la isla es de 1544 teniendo como beneficiario a García Ponce de León, en el cual ocurre lo mismo que en anterior. No se especifica ni sexo ni religión que profesan estas personas. ${ }^{37}$ En el que se le da licencia para llevar a la isla tres esclavos negros, aquí sí dejando constancia que van a servir bajo su persona.

En uno de los documentos que he analizado, la Real Cédula de 1560, dice así:

"Juan Ponce de León, alcaide de la fortaleza de la ciudad de Puerto Rico, nieto de Juan Ponce de León, colonizador de la isla de San Juan. Se le autoriza ir a las Canarias, desde donde puede tomar al-

35 COLL, Historia de la esclavitud en Puerto Rico.

36 Real Cédula a Cristóbal Ponce de León, dándole licencia para llevar a Indias 20 esclavos negros, pagando los derechos correspondientes, (1534). AGI. Indiferente, 422,L.16,F.102V(3).

37 Real cédula a García Ponce de León, dándole licencia para pasar a Indias 3 esclavos negros para su servicio, (1544). AGI. Indiferente, 423,L.20,F.750R(1). 
gún navío que vaya para Indias, y llevar consigo los 11 esclavos de que se le han dado licencia pero con la condición de que los registre antes en Sevilla". ${ }^{38}$

Es un ejemplo en el que las personas que se trasladan a la isla de San Juan provienen de fuera de la Península ya que se deben registrar en Sevilla para poder trasladarlos. No se especifica el color de la piel, como hemos visto en el caso anterior. Tampoco se describe el sexo de las personas y cuál es su religión. La ambigüedad de la información nos da una idea de que las características de estas personas que son trasladadas al "Nuevo Mundo" como fuerza de trabajo para este sistema esclavista de producción ya no es tan importante, lo importante es su trabajo, que sean productivos sin importar su religión o su sexo, e incluso su color de piel. Ya no se prima la evangelización de la isla, sino su productividad.

El último documento que se puede considerar de relevancia para este análisis es la Real Cédula dando licencia a Luis Ponce de León para "pasar a las Indias cuatro esclavos negros para su servicio". ${ }^{39}$ En este documento se sigue sin especificar la religión de las personas que se trasladan, siendo este un claro ejemplo de que la religión de estas personas no era tan importante como en un inicio.

Parece que el sistema productivo esclavista ya comienza a sustentarse en el tráfico esclavista, es cierto que en ninguno de los casos anteriores el número es muy elevado, y que en algunos de estos documentos se especifica que van a estar bajo el servicio del propietario. Pero, si abrimos un poco más la mirada y observamos otros documentos se puede ver una realidad que nos acerca a un sistema de producción cada vez más sustentado en el tráfico negrero. El documento que puede dar un poco de luz es el que hace referencia a la Virreina Doña María de Toledo casada con Diego de Colón, hijo de Cristóbal Colón. Mediante su análisis se puede observar que las licencias para llevar un número cada vez más elevado de personas esclavas a la isla de San Juan en particular y de las islas del Caribe en general se va normalizando. En este documento de 1534 se le da permiso a María de Toledo para llevar 100 esclavos, para las granjerías de las islas La Española, San Juan, Cuba y Jamaica. Aquí no es importante el que no

38 Real cédula a Juan Ponce de León, (1560). AGI, Indiferente, 425,L.23,F.469V-470R.

39 Real Cédula dando licencia a Luis Ponce de León para pasar a Indias 4 esclavos negros para su servicio. (1561). AGI, Indiferente, 425,L.24,F.41V. 
se especifique el sexo ni la religión, sino el número tan elevado de personas que se mueven para la producción esclavista de estas islas. En ningún documento analizado con anterioridad la cantidad de personas había sido tan elevado.

\section{Conclusiones}

Por lo tanto, y a modo de conclusión, se puede decir que el sistema de producción de la isla se vio influenciado por el sistema esclavista que estaba viviendo Europa y, más concretamente, España en ese momento. Ya que este no era un sistema que estuviese muriendo en absoluto, sino que se encontraba en un buen estado de salud. Era un sistema que producía mucha riqueza con un bajo costo. Es por ello que este sistema fue el que se instauró en las nuevas tierras "descubiertas" por Colón y, en el caso de la Isla de San Juan, colonizada más tarde por Juan Ponce de León.

Un sistema que se beneficiaba en un primer momento de los indios autóctonos de las islas, haciéndolos esclavos a través de las guerras. Su estatus fue cambiando a lo largo de las primeras décadas del siglo XVI, por la oposición y alegatos de teólogos y juristas, junto con el beneplácito de la Corona, para que estas personas comenzaran a estar bajo el servicio de colonos y caciques durante un tiempo determinado de tiempo, siendo posteriormente libres, mediante naboríos y repartimientos de Indios $\mathrm{A}$ esto se le une las pocas licencias que se concedían para pasar esclavos y esclavas a la isla desde la Península lbérica, convirtiéndose en un "objeto" de lujo y privilegio. Además estas personas tenían que tener una serie de características para hacerlos aptos. Entre estas estaba el ser cristianos y que trabajasen al servicio de su dueño. El color de la piel no es importante y se deja constancia si son hombres y mujeres. Se tenía una minuciosa descripción de toda persona que entraba en la isla.

Pero lo cierto, es que el sistema esclavista va cambiando en poco más de dos décadas, y esto se hace perceptible. Durante el primer siglo que dura la colonización de la isla su economía se sustentaba en las grandes plantaciones, lo que provoca que la necesidad de mano de trabajo esclava sea necesaria. La población taína y caribe se había reducido en gran 
medida y su posición como esclavos y esclavas era solo temporal, a esto hay que añadir que los esclavos y esclavas que procedían de la Península no era suficiente. Por lo que, llegó un momento, en el que estas licencias se concedieron dejando de lado los dos requisitos que se habían hecho imprescindibles en las primeras décadas, la religión que procesaban y que su ocupación estuviese bajo el servicio directo del propietario o propietaria, mirando hacia el África subsahariana como lugar para abastecerse de personas. La esclavitud se estaba convirtiendo en un proceso global, se estaba convirtiendo en un negocio que acabaría destrozando millones de vidas. 
Estudis 



\title{
MUJER, GUERRA Y ARTE: SIMBOLISMO EN LOS COLLAGES DE AMPARO SEGARRA
}

\author{
WOMAN, WAR AND ART: SIMBOLISM IN \\ COLLAGES OF AMPARO SEGARRA
}

\author{
$M^{a}$ Dolores Villaverde Solar \\ Universidad de A Coruña
}

No deseo que las mujeres tengan poder sobre los hombres, sino sobre ellas mismas.

Mary Wollstonecraft

\section{RESUMEN:}

El collage es una de las expresiones más significativas del arte del siglo XX, aunque en ocasiones se haya valorado en menor medida a otras artes. De igual manera muchas creadoras han sido olvidadas o desfavorecidas en la Historia del arte por el hecho de ser mujeres. Mujer creadora de collages ha sido Amparo Segarra, artista cuya vida cambió radicalmente a causa de la Guerra Civil y el exilio. Prefirió dedicarse al collage frente a otra técnica con creaciones en los que siempre denuncia desigualdades, opresiones, contrastes culturales y la importancia de la mujer en el devenir de la historia.

Palabras clave: Collage, surrealismo, mujer, simbolismo, guerra.

\begin{abstract}
:
Collage is one of the most significant expressions of twentieth-century art, although on occasion it has been valued to a lesser extent to other arts. In the same way, many creators have been forgotten or disfavored in the history of art because they are women. Woman who created collages was Amparo Segarra, an artist marked by the Civil War, exile. She preferred to dedicate herself to collage as opposed to another technique with collages for denounces inequalities, oppressions, cultural contrasts and the role of women in the evolution of history.
\end{abstract}

Keywords: Collage, Surrealism, Woman, Symbolism, War. 


\section{RESUM}

DONA, GUERRA I ART: SIMBOLISME EN ELS COLLAGES D'AMPARO SEGARRA

El collage és una de les expressions més significatives de l'art del segle XX, encara que en ocasions s'haja valorat en menor mesura que altres arts. De la mateixa manera moltes creadores han estat oblidades o desfavorides en la Història de l'art pel fet de ser dones. Dona creadora de collages ha estat Amparo Segarra, artista que la vida va canviar radicalment a causa de la Guerra Civil i l'exili. Va preferir dedicar-se al collage enfront d'una altra tècnica amb creacions en què sempre denúncia desigualtats, oppressions, contrastos culturals i la importància de la dona en l'esdevenir de la història.

Paraules clau: Collage, surrealisme, dona, simbolisme, guerra. 


\section{INTRODUCCIÓN}

Este artículo tiene su punto de partida en el proyecto de investigación "Sexismo y androcentrismo en la prensa periódica española", que inició en el año 2007 un grupo de investigadores/as de la Universidad de A Coruña dirigidos por la Dra. Elena Alfaya Lamas. Dicho proyecto nació con la intención de estudiar las diferencias y el sexismo que se evidencian en el lenguaje de prensa, pero, a medida que fue avanzando, se amplió con nuevas investigaciones en diferentes ámbitos de estudio. El proyecto, por su temática, en pleno 2019 todavía no puede darse por concluido, es necesario seguir avanzando en los estudios sobre cuestiones de género y así, este texto es una pequeña parte del análisis que se está realizando actualmente sobre la mujer en el arte, una de esas otras líneas de investigación abiertas, que empieza hace ya unos años con el estudio de las mujeres en la historia del arte, primero analizando el por- qué de su ausencia durante siglos, obligadas por las circunstancias sociales y culturales que provocan trabas en el acceso a estudios superiores o a su dedicación plena por el simple hecho de haber nacido mujeres en el seno de unas sociedades patriarcales. Se analizaron las causas del porqué se las excluye y también se analizó el papel de las artistas, así como la imagen que de la mujer se da en las obras de arte. De estas investigaciones se han publicado artículos en revistas especializadas, comunicaciones a congresos nacionales e internacionales, monografías y exposiciones, pero, aunque a día de hoy existen ya numerosos trabajos de investigación y una bibliografía interesante que van permitiendo situar a la mujer en su lugar correcto en el arte, la tarea no está terminada. El arte, de por sí no es machista, es machista la sociedad o las condiciones socioculturales, apreciándose desde las primeras manifestaciones artísticas desigualdades entre hombres y mujeres, que condujeron al silencio e invisibilidad de las mujeres, impidiendo que estudiaran, trabajaran o se dedicaran al arte en Occidente durante siglos, y así no aparece apenas ninguna artista hasta que llegamos a la mitad del siglo XX. Esto es algo que está tan arraigado que suele pasar desapercibido y llega a verse casi como normal cuan- 
do se estudia o lee algo sobre la Historia del arte de Occidente. Quizá lo era en la Edad Media, igual en el Renacimiento ya algo menos, pero, llegados a la Edad Contemporánea no debería seguir siendo así, parece que la mujer sólo sirviera para ser tema, modelo o protagonista de una obra de arte hasta un siglo XX bien entrado. En Galicia -comunidad a la que se referirá este texto-, la mujer está desaparecida en las artes igualmente, en el siglo $\mathrm{XVIII} \circ \mathrm{XIX}$ son figuras muy aisladas las que se conocen y algunas consideradas como meras aficionadas. Muy tardíamente, a partir de la segunda mitad del siglo XIX empiezan a aparecer matriculadas mujeres artistas en las Sociedades de Amigos y Escuelas de Bellas Artes, nacidas al abrigo de la llustración, a pesar de los problemas de acceso y reticencias. Las que conseguían acceder a estudios, al igual que en el resto de Europa, se encuentran aquí con dificultades. La incorporación a los estudios es lenta, las mujeres gallegas no pueden obtener la misma formación que sus compañeros, la que quiere ser pintora es vista como una despreocupada que se dedica a eso como algo secundario y las asignaturas recibidas en la academias eran diferentes, no se las acepta en pintura de desnudo, ni podían pintar cuadros de historia y básicamente la única institución que accedía a que las mujeres ingresaran en sus aulas era la Sociedad Económica de Santiago institución fundada en 1784 fue pionera en traer a Galicia las enseñanzas de las academias neoclásicas. Sus primeros intentos de dar formación artística a las mujeres datan del curso 1835-36, con un primer curso en el que habrá ochenta y ocho alumnos matriculados y cincuenta y cinco alumnas. La Sociedad Económica será la institución artística y cultural más importante para el avance en la formación artística de las mujeres, pero otras instituciones intentarán también prestar formación a las mujeres en la comunidad. Una de ellas será la Academia provincial de Bellas Artes de A Coruña, que en 1851 crea una escuela de dibujo de figura y adorno para mujeres - la Escuela provincial de Bellas artes, que en el curso 1879-80 crea su sección de señoritas. Habrá que esperar al siglo XX para poder ser aceptadas en el mundo de la creación y la colección del arte. A partir de entonces su ascenso será imparable, pero los inicios de su lucha por defender su espacio en el mundo artístico, es un camino difícil. Las que nacen a principios de siglo $X X$, tienen además, un nuevo problema, la guerra civil española, que obliga a muchas artistas a huir de España, otras deben dejar de dedicarse a su profesión y entre las primeras se encuentra la artista a la que se dedican estas páginas.

No es la pretensión de este artículo hacer un estudio histórico general sobre el papel de las mujeres en el arte, ni tampoco de su labor o lugar 
en la guerra civil, pero sí, a través del ejemplo concreto de Amparo Segarra, mostrar una de tantas injusticias que se produjeron en contra de las mujeres durante y después de la guerra civil española. Las mujeres, tanto mientras duró el conflicto bélico, como en la postguerra, fueron fundamentales. En la zona republicana sobre todo, lucharon en el frente y la retaguardia, otras trabajaron en fábricas mientras los hombres estaban luchando, estaban en organismos de mujeres que tuvieron un papel decisivo con las labores de auxilio. En la zona nacional, se creó el Auxilio de Invierno. Queda claro la importancia del trabajo que desempeñaron las mujeres durante el conflicto, bien fuera en el frente, en la retaguardia, en el campo o en el hogar, $y$, lo que se olvida muchas veces: el precio que tuvieron que sufrir, físico o emocional. Tras la guerra, hay episodios en la historia de las mujeres que quedan olvidados y la historia de las vencidas es todavía peor, pues la dictadura y falta de libertad impidió que se conociera, bando al que pertenece Amparo Segarra Vicente.

\section{Amparo Segarra Vicente}

El nombre de Amparo siempre ha estado vinculado a su marido, el artista surrealista Eugenio Fernández Granell, artista que nace en $A$ Coruña el año 1912, y fallece en Madrid en 2001. Hombre implicado políticamente, el estallido de la guerra civil y su filiación al bando republicano le obliga a huir de su país. No se tratará aquí de hacer un relato de su vida, pero sí es interesante señalar que a partir de entonces comienza un largo recorrido por varios países y ciudades, desde La República Dominicana,a Guatemala, Puerto Rico o Estados Unidos. En el periplo estuvo siempre acompañado de Amparo, su esposa, su amor, compañera de vida y consejera.

Amparo tuvo un papel fundamental en la vida privada y artística de Eugenio, junto al que puso en marcha la Fundación Eugenio Granell, centro referencial del arte contemporáneo en la comunidad gallega. Amparo es destacable no sólo por ser compañera del artista sino por ser también alma del centro hasta su muerte, estando presente en el patronato de la Fundación hasta su fallecimiento en el año 2007, siendo la actual directora su hija Natalia Fernández Segarra. Nació en Valencia en el año 1915, pero estudia varios años en un internado cerca de París. Tras su regreso a España se casa con Miguel Anglada, un militar fiel a la República. Al estallar la guerra civil, él acude al frente y ella, embarazada, va a Barcelona para dar a luz. Poco después viaja a Aragón, pero un bombardeo destruye la casa en la que vivía y decide volver a Barcelona. Su juventud estuvo por tanto, marcada por la guerra civil española que cambió su vida, al igual que la de otras muchas, o todas, las mujeres de su 
generación. Fue la guerra la que la obligó a irse de España en 1939 con su hijo aún muy pequeño y el que era por aquel entonces esposo, militar leal a la república. Aquí tenían dificultades para encontrar casa, trabajo o comida: "...había vivido todo el tiempo de guerra en Barcelona, me calificaban de roja y no me empleaban. Para poder comer tenía que ir a los Encantes, un rastro, a vender las sábanas de hilo y objetos de la casa. Con la escasez de comida durante la guerra y después, a pesar de que mi hijo tenía dos años, seguía dándole el pecho. lba al barrio chino de noche para comprar leche y aceite, pues con la cartilla de racionamiento sólo me correspondían para el niño tres botes de leche condensada por semana". ' Ante la situación, Amparo decide intentar salir de España, pero encuentra escollos también para encontrar el salvoconducto, que sólo consigue hasta Ripoll y de ahí gracias a la ayuda de un pastor puede finalmente avanzar y llega a conseguir un billete a Francia. En Francia hace una vida de refugiada medianamente normal pero otra guerra, la europea la obligará a irse a América. En un tren que conducía a Le Havre conocerá a Eugenio Fernández Granell. Artista gallego surrealista junto al que for- ma una familia y muchos años más tarde regresa a España y funda en Santiago de Compostela (A Coruña), la Fundación Granell.

El primer destino de ambos será República Dominicana pero los conflictos bélicos nuevamente harán que abandonen ese país, al negarse a firmar una carta de adhesión al régimen de Trujillo y se trasladan a Guatemala. Con el inicio de la revolución guatemalteca una vez más hay que huir, en esta ocasión a Puerto Rico y finalmente llegarán a los Estados Unidos. No volverán a España hasta el año 1985. Amparo y Eugenio están en todos estos destinos juntos, tienen una hija y así Amparo empieza una nueva vida, exiliada en un destierro que como dejó dicho la propia Amparo, duró más de cuarenta años. ${ }^{2}$ Son por tanto las guerras, desde la civil española a la europea o los conflictos sudamericanos, las que van dirigiendo el ritmo de su vida. Por ellas, o a pesar de ellas, debe dejar su país, su casa, sus raíces y su gente; en el exilio deberá pasar por varios países, que la acogen junto a su familia pero que no son el suyo, al que volverá junto con Eugenio en sus últimos años de vida y donde crearán la Fundación. El horror y el absurdo de una guerra fueron los causantes de que su vida cambiara por completo, y si

1 FERNÁNDEZ SEGARRA, Natalia, Collages. Amparo Segarra (Celebrada en Santiago de Compostela del 14 de abril al 26 de julio del 2000), Santiago, Fundación Granell, p.23.

2 FERNÁNDEZ SEGARRA, Natalia, Collages. Amparo Segarra, p.29. 
hay algo que le deba al exilio fue permitirle que conociera a Eugenio Granell, que se convirtió en su compañero de vida y de arte. Pero Amparo no solo tiene interés por ser la esposa de Granell, ha sido una de las artistas silenciadas de nuestra historia, eso se debe a que, por un lado, prefirió dedicarse al collage frente a otra técnica, pero también, de alguna manera, se mantuvo a la sombra de su marido, aunque no se sintiera relegada.

Muchas mujeres tras leer los párrafos anteriores se habrán sentido identificadas con estas frases, muchos niños/as habrán pasado por lo mismo en una época dominada por el hambre, el frío y las desigualdades para gentes de cualquier edad y profesión. Mujeres todas ellas valientes, luchadoras, que dejaron su juventud en unos años de lucha y penurias y a las que la historia ha tratado injustamente durante décadas. Cuando se habla de guerra civil se habla de países en lucha, de soldados que caen en el campo de batalla, de desertores, de emboscadas, pero se olvidan de las mujeres, tan importantes como los hombres aunque no estuvieran en los ejércitos. Todas fueron esposas, madres, hermanas o hijas; todas lloraron a sus muertos, cuidaron heridos o enfermos, intentaron parar la sinrazón, o estuvieron luchando. Si emigraron fue por causa de persecuciones, violaciones de los derechos humanos, pobreza, buscando una vida mejor, $y$, todas, al margen de bandos o co- lores, sin excepción, son protagonistas principales en ese momento de la historia de España.

Amparo huye de la guerra para salvar la vida de su hijo y no por estar casada con un militar en aquel momento lo tuvo más fácil. Buscando huir de una vida de penurias por estar en el bando perdedor, después de irse de España, Amparo no se conformó con ver la vida pasar y se fue adaptando a cada uno de los países que la acogen junto a su familia. Conoce y se amolda a las diversas culturas, a diversidad de situaciones y adversidades que fueron surgiendo, siempre, con Eugenio a su lado y el arte presente en la vida de los dos. En América llega a ser actriz de teatro, realiza para teatro los vestuarios de algunas obras, y es también en el continente americano cuando empieza a hacer sus collages de los que aquí se hará una revisión de los más interesantes. Dar forma al texto ha sido complejo, sobre todo por la falta de documentación. La Fundación Granell es la institución que me ha permitido conocer la obra de Amparo y los documentos o bibliografía (muy escasos) existentes sobre esta artista. Este es uno de los motivos, junto a su arte, por los que decidí investigar sobre sus collages, realizados de manera aparentemente sencilla pero muy complejos por temática y simbolismo.

A día de hoy la figura de Amparo sigue sin ser muy conocida a nivel internacional, y la mayor parte de 
las ocasiones se menciona como esposa de Eugenio Granell, quién, evidentemente no se debe obviar, ya que fue el compañero de vida y exilio de Amparo, con él se inicia en el mundo del collage, siendo los primeros que hace para una exposición de moda en compañía de su marido, pero Amparo es también artista con su nombre y apellidos, válida por sí misma y con un estilo e identidad determinados. Hay varios motivos que hacen de ella un personaje de interés: por un lado, haberse dedicado al collage. Por otro, por su visión surrealista del arte y el tratamiento a la mujer en todos sus collages, pero además su propia vida marcada por una ideología concreta, la guerra española y el exilio que cambiaron su vida y de alguna manera proporcionan los temas para sus obras artísticas.

\section{Desarrollo: Los collages de Amparo}

La técnica artística denominada collage consiste en la creación de obras mediante la unión de piezas o recortes de distinto origen sobre una tela, papel u otra superficie. Se vincula sobre todo a la pintura, relacionándolo con la obra artística de Pablo Picasso, quién se inició en el collage en su etapa cubista en 1912. A medida que se fue avanzando en la técnica, se fue ampliando y aparece el fotomontaje, que combina fotografía que combina elementos fotografiados superpuestos, famoso sobre todo por los vanguardistas del Dadá y los vanguardistas rusos que lo utilizan como medio de comunicación y propaganda política. El término se definiría así: "Técnica pictórica que consiste en componer una obra plástica uniendo imágenes fragmentos, objetos y materiales de procedencias diversas". Una palabra de tres sílabas que para siempre estará unida a diferentes estilos artísticos: cubismo, dadaísmo, constructivismo; a artistas de la talla de Picasso - Braque $y$, también a nombres de mujeres -la dadaísta Hannah Höch - la constructivista Varvara Stepanova, por señalar algunas-, y a las que hay que añadir el de la surrealista Amparo Segarra.

Para comentar los collages de Amparo, se parte de una fuente básica que es el propio collage, ya que es poca, casi inexistente, la bibliografía sobre esta artista. Ha sido fundamental para elaborar este texto consultar los fondos de la biblioteca y archivo de la Fundación Granell ${ }^{4}$, donde están sus obras y los artículos o catálogos que la mencionan. Esta es por tanto una aproximación a la obra de la artista que tiene como finalidad,-además de revalorizar la figura de Amparo Segarra-, ser el

4 Desde aquí doy las gracias al personal de la Fundación Granell por las facilidades dadas para poder acceder a los fondos ahí custodiados. 
punto de partida para futuras investigaciones. En sus collages, existen características de estilo propios, aunque Amparo Segarra no tenía una técnica definida, sencillamente recortaba y pegaba, en apariencia sin un orden, para Amparo los collages no tienen que tener un material sofisticado, ni delicado, tampoco hacen falta normas, une cosas aparentemente inconexas, que no deberían ir juntas, fragmenta, generando siempre tensión ante lo que el espectador observa. Junto a la tensión sus collages tienen que transmitir algo más, siempre hay una simbología, provocan sentimientos, desde melancolía a rabia o tristeza. Se han elegido collages que aparentemente son muy simples en composición y casi sin sentido que representan una cosa, pero si se sigue indagando, la interpretación final de figuras $u$ objetos las convierte en algo totalmente diferente, y analizarlos se observa que echan mano de una serie de elementos alegóricos o metáforas que dejan patente la vigencia o dependencia que el arte sigue teniendo del emblema, la alegoría o el símbolo.

Y todos, del primero al último creado mantienen estética y carácter surrealista.

En ellos hay una serie de elementos o símbolos constantes:

A) la oposición de contrarios: tanto hombre - mujer; oriente - occidente; piedra - carne; religioso - laico.

B) la figura femenina: es raro que no aparezca alguna mujer en sus collages. Si la mujer está vestida es normalmente una mujer sometida, sumisa, conformista, pero si está desnuda, no es tan sólo un desnudo femenino, es consciente de su desnudez que se convierte en metáfora de una mujer libre, sin ataduras y tan perfecta como la Venus Celeste neoplatónica.

C) Los militares: que siempre son metáfora de autoridad y represión.

D) El caballo: relacionado normalmente con el papel de dominio del hombre en las sociedades patriarcales.

Con esos símbolos unidos aparentemente sin sentido, expresa variedad de temáticas, entre las más recurrentes de sus collages: las denuncias de desigualdades, opresiones, los contrastes culturales y la mujer, que siempre está presente en ellos por su importancia en el devenir de la historia. Por qué elige esos temas solo ella podría explicarlo, pero es innegable que su ideología, el haber vivido la guerra, y un largo exilio son los referentes de la elección de cuestiones que se repiten, desde las críticas religioso-políticas, a los militares, la opresión o desigualdades en distintas civilizaciones o sociedades, y la mujer, siempre la mujer, desde la sumisa a la luchadora, de la reprimida a la liberada. Todos sin excepción mantienen el espíritu surrealista en el que desarrollaron toda su vida artística Amparo y Eugenio, y en ellos, al igual que en los cuadros o esculturas de Granell, no solo juega el azar en la colocación 
de objetos; las propias vivencias de la autora, junto a otras fuentes como la emblemática, los jeroglíficos, la literatura, o la mitología.

Sin duda, los más interesantes por su simbolismo y por los temas tratados en ellos, son los realizados por una Amparo ya mayor (la década de los noventa del siglo XX y los primeros años del XXI), esto les da más importancia ya que en las últimas décadas se ha ido generando una sociedad que promueve la juventud y la belleza a toda costa, con fotos retocadas, cuerpos perfectos, cremas anti ojeras y líneas de expresión que nos saturan a todas horas sobre todo al género femenino. Esto lo único que ha conseguido es que la sociedad actual, la de finales del XX y estas primeras del XXI, en vez de apreciar la madurez, aportaciones y sabiduría de los mayores los relega sin valorar su verdadera esencia y enseñanzas. Los collages de estos últimos años de Amparo Segarra, son los de una persona implicada social y culturalmente, preocupada y reivindicativa que realiza sus collages más críticos que invitan a una mayor reflexión. A ellos nos referiremos en las siguientes páginas, pero para llegar a estas piezas es preciso hacer un breve resumen de lo que fue su obra: Los primeros collages de Amparo los realizó en colaboración con su marido, fueron confeccionados con el fin de mostrar diversos monumentos y costumbres europeas a alumnos de Gra- nell para prepararlos para su viaje a Europa. Son los collages de los años cincuenta realizados en Puerto Rico en los que Amparo recorta imágenes de revistas con mujeres perfectamente vestidas y peinadas que se convierten en simples muñecas para ser vistas o admiradas 5 - siempre pasivas - Pero los tiempos van cambiando y el collage en Amparo también, ya en los años sesenta y setenta deja ejemplos en los que cuestiona problemáticas sociales, políticas o culturales. En la década de los noventa, realiza los más interesantes demostrando que a pesar de su edad, no es ajena a la problemática, discriminación y violencia sufrida por las mujeres en la sociedad.

La selección de obras se centra en los realizados en la década de los noventa, si bien es necesario iniciar el recorrido por algunos de los años sesenta y setenta, puesto que ya en ellos se aprecian los intereses y cuestiones que más preocupan a Amparo y que coparán la mayor parte de sus últimos collages. Todos repiten símbolos o elementos y se centran sobre todo en tres asuntos: cuestiones ideológico-políticas, feminismo y antibelicismo.

Where have all the flowers gone (fig.1) de 1960, es el que inicia este recorrido por ser el collage de Amparo Segarra que toca más de cerca la temática de la guerra y se convierte en su alegato antibe-

5 Como en Concierge, o El Prado. 
licista. Está basado en la canción han ido todas las flores?, icono andel mismo título: Where have all tibelicista famoso en la historia de flowers gone es un collage de 1960 la música. basado en la canción ¿̇Adónde se

¿Dónde han ido a parar todas las flores, ha pasado mucho tiempo? ¿Dónde han ido a parar todas las flores, hace tanto tiempo?

¿Dónde han ido a parar todas las flores?

Las chicas jóvenes las han cortado todas.

Oh, ¿̇cuando van a aprender?

Oh, ¿̇cuando van a aprender?

¿A dónde se han ido todas las chicas jóvenes, ha pasado mucho tiempo?

¿A dónde se han ido todas las chicas jóvenes, hace tanto tiempo?

¿A dónde se han ido todas las chicas jóvenes?

Se han ido a buscar marido todas ellas.

Oh, ¿̇cuando van a aprender?

Oh, ¿̇cuando van a aprender?

¿A dónde se han ido todos los maridos, ha pasado mucho tiempo?

¿A dónde se han ido todos los maridos, hace tanto tiempo?

¿A dónde se han ido todos los maridos?

Se hecho todos soldados.

Oh, ¿̇cuando van a aprender?

Oh, ¿̇cuando van a aprender?

¿A dónde se han ido todos los soldados, ha pasado mucho tiempo? ¿A dónde se han ido todos los soldados, hace tanto tiempo?

¿A dónde se han ido todos los soldados?

Se han ido a la tumba, todos.

Oh, ¿̇cuando van a aprender?

Oh, ¿̇cuando van a aprender?

¿A dónde se han ido todas las tumbas, ha pasado mucho tiempo?

$\dot{\imath}^{A}$ dónde se han ido todas las tumbas, hace tanto tiempo?

¿A dónde se han ido todas las tumbas?

Se han ido a por flores, todas.

Oh, ¿̇cuando van a aprender?

Oh, ¿̇cuando van a aprender?

¿Dónde han ido a parar todas las flores, ha pasado mucho tiempo?

¿Dónde han ido a parar todas las flores, hace tanto tiempo?

¿Dónde han ido a parar todas las flores?

Las chicas jóvenes las han cortado todas.

Oh, ¿̇cuando van a aprender? Oh, ¿̇cuando van a aprender? ${ }^{6}$ 


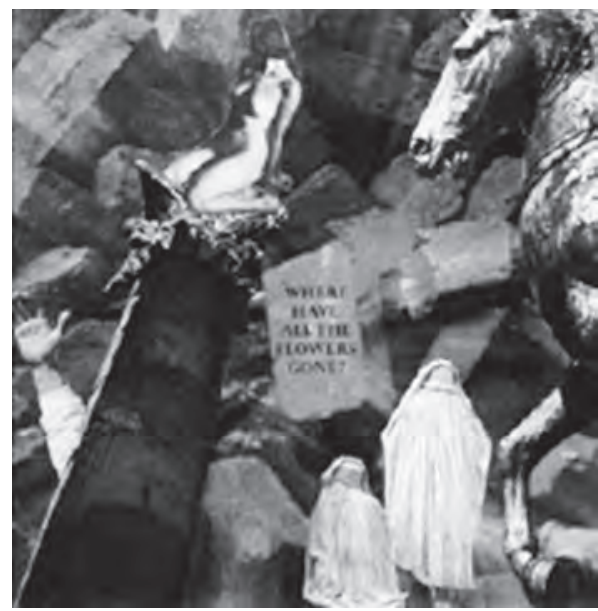

La melodía y las tres primeras estrofas fueron escritas por Pete Seeger en 1955, y el resto es de Joe Hickerson (1960). Refleja el sin sentido de la muerte en las guerras que inician - hacen los hombres y en la canción la interrogación ¿adónde? está siempre presente.

Amparo, tomando como base la letra de la canción elabora un collage con el mismo título el mismo año en que Joe Hickerson la completa. Algunos de los elementos fetiche de sus collages se acumulan en esta imagen dominada por una enorme columna. La columna en el arte simboliza la fortaleza, la seguridad, la templanza. Aquí sin embargo, esa fortaleza no es tal, la columna no se alza vertical, se desploma, y al hacerlo aplasta a un hombre, que, siguiendo la letra de la canción, es
Fig. 1.- Where have all the flowers gone (1960). Imagen extraída de FERNÁNDEZ SEGARRA, Natalia, Collages. Amparo Segarra (Celebrada en Santiago de Compostela del 14 de abril al 26 de julio del 2000), Santiago, Fundación Granell.

el soldado muerto de forma absurda. El caballo a trote que se ve a la derecha, aparentemente no tiene ninguna vinculación ni sentido aquí, sin embargo en la historia y el arte el caballo simboliza desde la antigüedad ayuda para los trabajos del hombre, también es transporte, y sobre todo, es símbolo de hombría y del guerrero. Es muy grande respecto al resto de elementos, para entender su significado hay que ir a la literatura emblemática. La relación entre pintura y emblemática no es algo que se restringe en el tiempo ni se limita a una etapa de la historia. Los artistas modernos y contemporáneos cuentan con una fuente de inspiración fundamental en la literatura emblemática, y en los emblemas un gigante representa siempre al ignorante. Uniendo por tanto, todos

6 Traducción de la autora del texto original en inglés. 
Fig. 2.- US Mail (1970). Imagen extraída de FERNÁNDEZ SEGARRA, Natalia, Collages. Amparo Segarra (Celebrada en Santiago de Compostela del 14 de abril al 26 de julio del 2000), Santiago,

Fundación Granell.

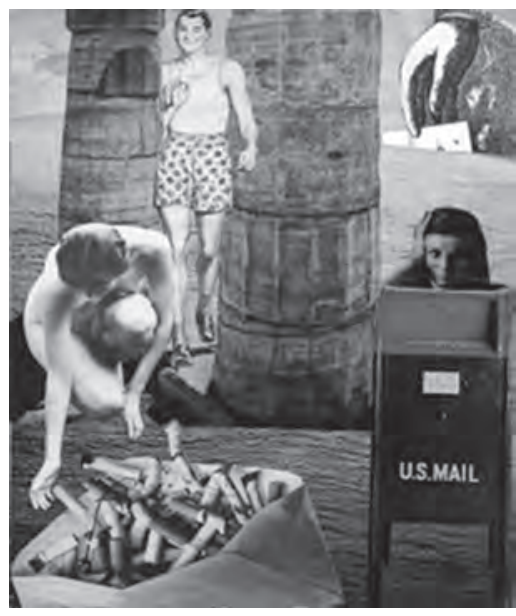

los elementos y sus significados, es un collage que critica la necedad e ignorancia del hombre como origen de guerras absurdas con perdedores en cualquier bando.

Como no podía faltar en un collage de Amparo Segarra, hay figuras femeninas: dos mujeres cubiertas con burka que parecen diminutas bajo el animal y de las que no vemos el rostro, miran hacia un fondo rocoso y abrupto, ${ }^{7}$ es la vida de la mujer sometida y sumisa que no tiene salida frente a ese hombre que genera y hace guerras. Por encima de todo ello está otra mujer desnuda sobre la columna. Es la mujer liberada, independiente, que no cae en los mismos errores de los hombres y las mujeres resignadas. Es la esperanza en un mundo mejor.

Diferente en simbología pero repi- tiendo ciertos elementos en 1970 realiza US Mail (fig.2). Este collage hace básicamente referencias al mundo contemporáneo con sus aciertos y errores. En un primer golpe de vista recuerda al icono del arte pop ¿Qué hace los hogares de hoy tan diferentes, tan atractivos? (1956), de Richard Hamilton. Al igual que en ese, hay menciones a la vida moderna, en concreto de los EE.UU. Los años vividos allí por la artista y su familia (entre 1956 y 1985) son los que sirven de inspiración a la pieza, son años -1960 a 1980- que están marcados por la Guerra de Vietnam, por la segunda oleada feminista, por la Guerra fría, la carrera espacial, consumo de drogas y hippismo o el caso Watergate. Un país con una economía próspera al principio y una gran

7 En una composición muy similar al padre y al hijo protagonistas de la pintura realista Los picapedreros de Gustave Courbet (1849) que reflejan la vida de los sin tierra. 
recesión hacia 1970. Un país por tanto lleno de contradicciones con grandes avances (oleada feminista, carrera espacial) y grandes errores (consumo de drogas o guerra de Vietnam). Amparo lo sintetiza todo en las imágenes recortadas. El hombre moderno entre las columnas antiguas simboliza la mezcla entre lo nuevo y lo viejo del país, los aciertos y errores. Pero es un hombre sólo vestido con ropa interior, por tanto incompleto. Nuevamente la mujer, es la que puede cambiar el destino del país, y una vez más lo señala con dos: una melancólica (con la mano en la mejilla, emblema de la melancolía) que está escondida dentro del buzón: es la anclada en el pasado, pero la otra está fuera, desnuda y libre: la que marca los avances de la sociedad americana, la que completa al hombre y gracias a la que ascenderá el país.

Esta visión ácida y crítica de determinadas situaciones que en estas décadas pasadas esboza en algunos collages se convierte en lo habitual llegados los años 90.

La constante mirada episcopal (Años 90). En composición, remite a una de las obras emblemáticas de la historia del arte, El Juramento de los Horacios, ${ }^{8}$ donde tres arcadas organizan el espacio, bajo las que se se van colocando los grupos de personas. En el cuadro los valerosos son los hombres que juran lealtad a la patria y parten para la guerra frente a las mujeres que únicamente saben llorar y lamentarse....El collage de Amparo es totalmente diferente en temática, pero igualmente dos arcos ordenan la composición. La pieza es una crítica a cómo la Iglesia oficial ha condicionado la historia del mundo (tanto en Oriente como Occidente) durante siglos. El robot, se sitúa frente máquina o

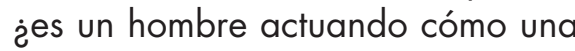
máquina?. Otra de sus constantes, la oposición entre masculino y femenino se indica aquí de forma muy velada, con los tradicionales colores azul para el ojo masculino, rosa para el femenino. Es otra voz crítica hacia las mujeres tradicionales apegadas a los dictados de la Iglesia que no saben salirse de las normas de la moralidad y actúan mecánicamente sin rebelarse. La mirada masculina acecha, casi amenazante. En el espacio antes comentado está todo muy equilibrado, pero ese equilibrio puede venirse abajo en cualquier momento.

Repsol (1990). Vuelve sobre temas ideológico-político y sociales. Está presidido por un Papa estrambótico que da la espalda al público, con gente de diversas edades, razas o géneros entre los que se encuentra el ex presidente del gobierno de España José María Aznar vestido

8 Pintada en 1784 por el artista neoclásico Jacques Louis David. 
con un mono de la escudería Repsol sosteniendo una enorme barra de pan. Es una imagen absurda aparentemente, pero no busca ser irónico, burlesco o humorístico, es una pieza crítica con la Iglesia oficial, con determinados partidos políticos y gobernantes que para la creadora dan la espalda al pueblo que queda detrás. Sobre las ropas papales aparece una abeja, animal que en diversas civilizaciones tiene simbolismo dispares. En el Antiguo Egipto suele aparecer en tumbas como símbolo de supervivencia del Ka o espíritu tras la muerte, y en el cristianismo se habla de la abeja como difusora de la luz del mundo, algo relacionado con Cristo, con la distinción entre el bien y mal: Yo soy la luz del mundo; el que me sigue, no andará en tinieblas, sino que tendrá la luz de la vida (Juan 8:12). Abejas aparecen también en el Estado del Vaticano, en el escudo del papa Urbano VIII o en el baldaquino de San Pedro realizado por Bernini en el siglo XVII, también en diversos escudos de dinásticas monárquicas, siempre relacionando este insecto con el orden de su colmena y su reina, la única que gobierna y manda, siendo esta la función del Papa en la Iglesia o la rey en su Estado.Junto a la abeja se observan mariposas cuyo significado es representar la transformación y evolución en la vida por su proceso de metamorfosis que las hace pasar de estar encerradas en un capullo, luego volar libres, su vínculo con los seres humanos vine por la lucha del hombre y mujeres por mejorar, transformar su vida y evolucionar. En este collage se superponen abeja y mariposas, es la contraposición entre la Iglesia o gobiernos anclados en el pasado y la lucha por transformar el mundo y evolucionar.

Mujer esclavizada (Años 90).Dos mujeres, una vestida y una desnuda, pero ambas cubiertas por un burka están rodeadas por hombres que las miran. Entre ellos, unos alzan sus manos y otros visten uniformes militares. Es uno de sus collages más simbólicos y explícitos sobre la discriminación, sometimiento y subordinación de las mujeres frente hombre. El burka, símbolo de antonomasia de la dictadura de los hombres se completa con el gesto de levantar la mano y con los uniformes.

De la cloaca al aire (Años 90). Mantiene el mismo tono crítico al presentar saliendo de sendas alcantarillas a un hindú y una mujer alzando las manos al cielo. Una segunda mujer aparece desnuda tras un cortinaje rojo, tímidamente se asoma la mujer por fin libre. Amparo se acerca en ambos collages a conceptos tan actuales como igualdad o ciudadanía y lo hace comparando la situación de las minorías étnicas y de las mujeres, si bien hay una esperanza, la que alza las manos es la mujer moderna y por fin, libre opuesta a la mujer pasiva objeto de deseo de los hombres. 
El caballo es el amigo del hombre (1998). Es el ¿amigo? No según se muestran aquí ambos. El caballo encabritado está bajo un hombre desnudo, enorme frente al animal. No parecen semejantes para ser amigos, el humano está por encima del animal, lo doma, o lo domina. Como ya se indicó anteriormente, el caballo desde ayuda para la agricultura, a la guerra transporte. Símbolo también de hombría, y de guerreros o militares. Aparte de estos significados también, desde el Renacimiento con los neoplatónicos, es símbolo del amor bestial. Tomando como ejemplo el cuadro de Tiziano Amor sacro y amor profano (1514), en el sarcófago, se talla una escena que alude a una violación y en la que aparece el caballo. El caballo es la representación de un tercer tipo de amor neoplatónico junto al Amor Celeste y al Amor Vulgar que representan, respectivamente, las mujeres desnuda y vestida, es el Amor Bestial, irracional. Siglos después, manteniendo este mismo simbolismo Füssli en La pesadilla (1781) vuelve sobre el mismo tema al representar la pesadilla erótica de la mujer protagonista que está siendo poseída por un demonio que se presenta en sueños, apareciendo en segundo plano la cabeza de un caballo de aire fantasmal que contempla la escena.

El fin del stalinismo (1998). Con este título y esta compleja composición recrea en imágenes el fin de esa era, un rebaño de ovejas que acude a una puerta es la masa humana que sigue los postulados del estalinismo sin saber lo que hay detrás. El fondo de la pieza es una huella dactilar que sobre la que cae el hombre y la acidez del limón riega todo. Con imágenes tan dispares, refleja a la perfección el pesimismo por la destrucción del comunismo y tiene un componente autobiográfico pues en la huida de Amparo de Guatemala estuvo el temor a la persecución estalinista.

Bien es cierto que no todos los collages son tan críticos, La orquesta pingüina (1998) es la visión surrealista del transcurrir de la vida. Un reloj, siempre simboliza en el arte el paso del tiempo eso los pingüinos somos todos nosotros en nuestro devenir diario, nuestras rutunas, trabajos, etc., a veces in pararnos a pensar y actuando como meros autómatas. Mientras, viendo todo desde arriba está el anciano. Es sin duda una vanitas contemporánea y surrealista.

Los siguientes collages son muy similares en su significado, resaltando el valor y posición de las mujeres en el mundo y la historia. Uno de los más significativos es La alegoría del pan, de 1999 (fig.3).Para este título Amparo Segarra utiliza una frase bíblica, la alegoría del pan se menciona en el Evangelio de San Juan (6,41-51) haciendo referencia al pan del cielo. En aquel tiempo, los judíos criticaban a Jesús porque había dicho: "Yo soy el pan bajado del cielo», Os lo aseguro: el que cree tiene vida eterna. Yo soy el pan 
Fig. 3.- La alegoría del pan (1999). Imagen extraída de FERNÁNDEZ

SEGARRA, Natalia, Collages. Amparo Segarra (Celebrada en Santiago de Compostela del 14 de abril al 26 de julio del 2000),

Santiago, Fundación Granell.

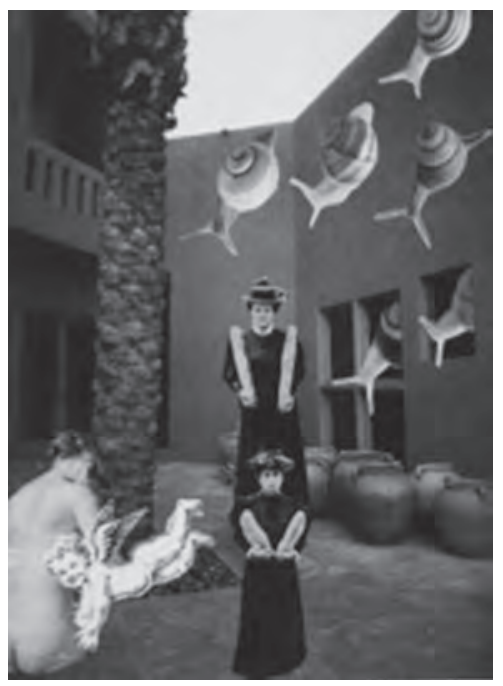

de la vida. Vuestros padres comieron en el desierto el maná y murieron: éste es el pan que baja del cielo, para que el hombre coma de él y no muera. Yo soy el pan vivo que ha bajado del cielo. A partir de esta frase del Evangelio elabora un collage que se convierte en un auténtico homenaje a las mujeres, utilizando esos términos bíblicos transforma a la mujer en la alegoría del pan, y lo hace de la manera que mejor sabe, con la oposición de una la mujer vestida frente a que está desnuda, y con un elemento vertical que compone el espacio. ¿Qué significa y por qué este título?. Tras su análisis se llega a la conclusión de que no es más que una nueva versión de La sorpresa del trigo que Maruja Mallo9 pinta en 1936, justo antes de la guerra. El lienzo de Mallo nos acerca a una Maruja revolucionaria, defensora de los trabajadores y sus derechos. Es una exaltación del trabajo campesino, pero lo hace de una manera poco convencional, con la imagen de una mujer sobre un fondo neutro de cuyos enormes dedos de la mano derecha brotan espigas que mira asombrada mientras en la otra muestra dos semillas. Las manos son las manos de todos los trabajadores del campo con las que se hace el pan que es el alimento por excelencia. Para realzar todavía más el esfuerzo de los campesinos y su trabajo equipara ese trabajo a la capacidad de la mujer para dar vida, para germinar algo nuevo, de ahí que eche mano de una representación femenina. La ins-

9 Pintora surrealista gallega nacida en Viveiro en 1902 y fallecida en Madrid en 1995 
piración de Maruja para esta obra fue la manifestación del primero de mayo de 1936, que veía desde Colón, entre las agrupaciones proletarias apareció un brazo sosteniendo una enorme barra de pan y ahí encontró la imagen que quería pintar. Con ciertas similitudes estas mujeres que portan barras de pan representarían lo mismo, pero en este caso detrás de ellas se ven caracoles. El caracol en heráldica significa ponderación, firmeza, por supuesto lentitud, y su caparazón representa el laberinto, el infinito, así como en culturas indias concepción, embarazo y parto. Si se unen todos los símbolos, el significado final de la pieza es la capacidad de germinar vida de las mujeres, pero no sólo por poder dar a luz a otros seres, también porque ellas son el pan de las sociedades, gracias a la mujer se mantienen o avanzan muchas de ellas tanto del pasado como del presente. El desnudo como en todos los collages es símbolo de liberación, de mujer libre y plena.

$Y$ en esa misma línea, el mismo año, 1999, crea La mujer liberada, está tapándose púdicamente como las Venus clásicas pero mira fijamente al espectador, es consciente de su lugar el mundo y una vez más la desnudez la muestra libre totalmente de ataduras. Los hombres que la rodean son símbolos de poder, autoridad o de falsa superioridad, uno corre dándole la espalda y el otro vigila.

Los temas y símbolos tan repetidos esta década son continuados de alguna manera en los realizados tras la muerte de su marido Eugenio Fernández Granell, manteniendo ese mismo espíritu reivindicativo.

El fantasma se va (2005).La imagen permite ver literalmente como se va lo que parece un ser un espectro. Es el fantasma del mal hombre que somete a las mujeres, tanto a las vestidas con burka como a la que está castigada de rodillas y espalda. El hombre se muestra decaído, con la mano en la mejilla, siempre símbolo del melancólico. Es un hombre melancólico o triste pero no por la situación de las mujeres, lo está por la pérdida de su poder sobre ellas, de ahí la frase los hombres nunca lloran, nunca..., lema que durante siglos se mantuvo como símbolo de hombría, soberanía o dominio de los hombres, y que en el siglo XXI ya no tiene sentido, pues este es el siglo de las mujeres.

Sorpresa nevada para las monjas (2006) No deja hasta sus últimas obras de repetir ciertos símbolos: el caballo y las mujeres, uniendo vestidas y desnudas. Las mujeres vestidas de tal forma que ocultan por completo su anatomía siguen siendo las mujeres sometidas y sumisas, el grupo de mujeres desnudas que están detrás alzan las manos y la voz: son las mujeres totalmente libres y modernas. Hacia ellas van los caballos pero no las alcanza, es la dominación del hombre que ya no puede con ellas. La parte inferior del collage se ocupa con todas las 


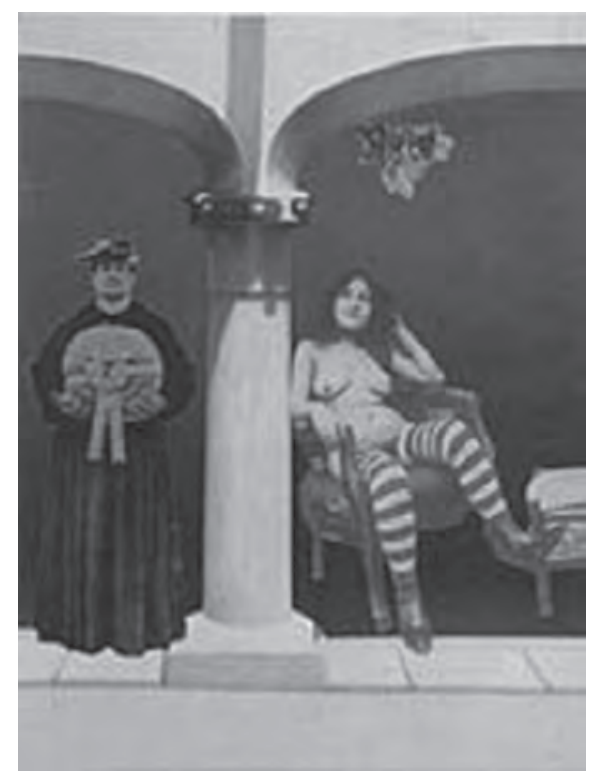

Fig. 4.- La hogaza de pan (2006). Imagen extraída de

http://www.eegee3.com/exposicion\%20Amparo\%20Segarra.htm.

mujeres tapadas: las vestidas con sus hábitos iguales sin diferenciarse disparan nieve a una pareja, surrealista y absurda pues él no tiene cabeza les otra vez un hombre incompleto) y ella es una joven sumisa que baja la mirada ante él.

La hogaza de pan de 2006 (fig.4). Es un tema ya representado en imágenes por Amparo. La hogaza de pan es la versión o continuación del 2006 a La alegoría del pan (1999). Amparo vuelve sobre la misma temática pero en este sintetiza y reduce: Una gran columna separa a dos mujeres: una de más edad vestida y una joven desnuda. La vestida es la que lleva la hogaza, es por tanto la que consiguió ciertos logros so- ciales que mejoraron la situación de las mujeres actuales representadas en la joven desnuda que se muestra descansada y despreocupada.

\section{Conclusiones}

Es indudable que el collage es una de las expresiones más significativas del siglo XX, aunque en ocasiones se haya valorado en menor medida a otras artes como la pintura - la escultura. De igual manera durante siglos muchas creadoras han sido olvidadas o desfavorecidas en la Historia del arte por el hecho de ser mujeres. Si unimos ser mujer, artista de collages y nacer a principios del siglo XX podríamos hacer 
un listado no muy largo, pero entre esos nombres aparece Amparo Segarra y estas líneas tratan de ser un homenaje y darle el prestigio que merece en la Historia del arte. Hasta ahora ha sido una de las silenciadas del arte, su posición difícil en la juventud por su ideología política afín al bando republicano, su vida en el exilio pasando por diferentes países hasta poder echar raíces en alguno, vivir al lado de un genio como Eugenio Fernández Granell, hizo que ella no llegara a dedicarse plenamente al arte ni a ser todo lo reconocida que debiera, aunque nunca se sintió infravalorada. Era artista de collage porque le gustaba hacerlo sin esperar un reconocimiento, pero ahí están y no deben caer en el olvido, es de obligación que se valoren y difundan. Mantienen el espíritu surrealista en el que vivieron la pareja Amparo-Eugenio y tienen sus fuentes en la historia del arte, en la emblemática, los jeroglíficos, la literatura, los refranes o la mitología complicando la percepción de las obras. A través de ellos se tratan temas como el paso del tiempo, la transitoriedad de la vida, - la posición de importancia de las mujeres en la historia, pero, lo más importante es la carga crítica o de denuncia que nos permite ver a una Amparo comprometida con la situación de los más desfavorecidos u oprimidos, con cuestiones, como el feminismo o el antibelicismo. Desde los inicios de los años cincuenta la mujer es una constante, es raro el collage que no incluye una o varias, siempre alternando desnudez y ocultamiento del cuerpo. Con la desnudez Amparo lo único que pretende es indicar que se desnudan libremente, no son desnudadas por la artista, está vinculando la desnudez del cuerpo femenino a la independencia, pues el fin último de toda esta selección de imágenes es defender la independencia y libertad de las mujeres que están dominadas únicamente por sí mismas, no por hombres, política, religiones o autoridad.

"El arte es una mentira que nos hace darnos cuenta de la realidad", decía Pablo Picasso, de igual manera Amparo con imágenes aparentemente absurdas en ocasiones, otras veces inexplicables por la unión de objetos inconexos, sin orden y representaciones enrevesadas nos hace una crónica de diferentes momentos de la historia, de la sociedad y el devenir de las mujeres.

Sus collages están a la altura de la obra artística de otras mujeres de diferentes épocas y estilos, activistas feministas como la alemana Hanna Höch (1889-1978), cuyo arte trata de exteriorizar a la mujer nueva de la República de Weimar y denuncia la sociedad machista existente; Martha Rosler (Brooklyn, Nueva York, 1943) que se centra en las mujeres y su situación en determinadas guerras como Iraq o Afganistán; Nancy Spero (Cleveland, Ohio, 1926 Nueva York, 2009) pionera del arte feminista, que entre las temáticas 
que trabajó destacan las guerras y las mujeres, denunciando presión, tortura, desigualdad, y el absurdo de la guerra; o Shirin Neshat (Irán, 1957) una de las artistas más importantes del arte iraní contemporáneo, con una obra que se caracteriza por el tratamiento de la condición de la mujer, en las sociedades islámicas contemporáneas, solo por mencionar algunas. Estas creadoras y Amparo coinciden en algo: todas vivieron o son conocedoras de alguna situación de conflicto bélico y de la situación de desamparo, abuso, o discriminación de las mujeres. Su arte, -que mantiene rasgos de estilo distintos, pues son creaciones que nacen y se desarrollan en épocas dispares- sirve para hacer frente a la sociedad establecida a la que critican. Buscan servir de ayuda, ser denuncia, llamada de atención y tratan de conseguir un mundo mejor para el colectivo femenino, el más desfavorecido y golpeado en situaciones de guerra, postguerra o en países pobres. Su manera de hacerlo es plasmando sus mensajes en dibujos, fotografías, performances, instalaciones, o collages, que es el medio que eligió Amparo Segarra. En la historia del arte tiene su lugar y por méritos propios merece ser reconocida.

\section{Bibliografía}

BLANCO MARTíNEZ, Rogelio, "Inventar la vida: la tarea de Amparo Segarra", en El Odre de Agar. Madrid, Ediciones Endymion, 2005, pp.123-128.

COMBALÍA, Victoria, Amazonas con pincel. Barcelona, Ediciones Destino, 2006.

COMBALÍA, Victoria, "Amparo Granell" En 2012 Centenario Eugenio Granell. Santiago, Fundación Eugenio Granell, 2012, pp.99-109. El juego de los espejos. Colección surrealista. León, Fundación GraneII, 1996.

FERNÁNDEZ SEGARRA, Natalia, Collages. Amparo Segarra (Celebrada en Santiago de Compostela del 14 de abril al 26 de julio del 2000), Santiago, Fundación GraneII, 2000.

GUIJON, Emmanuel, Historia del collage en España. Museo de Teruel, 1995.

ITURBE, Lola, La mujer en la lucha social y en la guerra civil de España. Madrid, LaMalatesta editorial, 2012. LAGARDE, Marcela, "Identidad femenina", en

https://xenero.webs.uvigo.es/profesorado/purificacion_mayobre/ identidad.pdf.En línea. [Consulta: 14-02-2019].

LOPO, María, "Amparo Segarra. Alén dos pirineos". Unión libre. Cadernos de vida e culturas. Número 11, Ediciós do Castro, 2006, pp. 141-144. 
$\mathrm{NASH}$, Mary, Rojas: las mujeres republicanas en la Guerra Civil. Madrid, Taurus, 1999.

SÁNCHEZ OMS, Manuel, El collage, cambio esencial en el arte del siglo XX: el caso aragonés. Universidad de Zaragoza, 2007. https:// zaguan.unizar.es/record/9894/ files/TESIS-2012-130.pdf

SEGARRA, Amparo, "La guerra ha terminado", en Nuevas raíces. Testimonios de mujeres españolas en el exilio. México, Contrapuntos, 1993, pp.21-30.
TUR, Francesc, "El abuso sexual de la mujer como arma de guerra en la zona nacional" en Ser histórico. Portal de historia, 2017. https:// serhistorico.net/2017/03/29/elabuso-sexual-de-la-mujer-como-arma-de-guerra-en-la-zona-nacional/ [Consulta:9-03-2019].

WESCHER, Herta, La historia del Collage, Barcelona, Gustavo Gili, 1977. 


\section{Raúl González Arévalo}

Profesor Titular de Historia Medieval en la Universidad de Granada. Sus líneas de investigación se han centrado en la historia social y económica del Mediterráneo occidental y el primer Atlántico, con especial atención al comercio de esclavos en el Reino de Granada tras la conquista cristiana, los cautivos cristianos en el Magreb y las relaciones entre la península ibérica y la península italiana entre mediados del siglo XIII y principios del siglo XVI.

rgonzalezarevalo@ugr.es

\section{Tamara láñez Ramírez}

Licenciada en Historia por la Universidad de Granada. Grado en Antropología Social y Cultural (Universidad de Granada). Máster en Arqueología (Universidad de Granada). Contratada como Personal de apoyo en el grupo de investigación "Etnografías simétrica y colaborativa. Una propuesta teórica, metodológica y pedagógica a través de tres etnografías experimentales" de la Universidad de Sevilla.

neztamara@gmail.com

\section{Aurelia Martín Casares}

Catedrática de Antropología Histórica en la Universidad de Málaga. Especialista en esclavitud, servidumbre y minorías étnicas en la Historia de España. Ha liderado seis proyectos de I+D y una Red de Excelencia del Plan Nacional de Investigación. Ha realizado estancias de investigación en diversos centros de prestigio (University of British Columbia, UCL, EHESS-París, Queen Mary College, Université de Toulouse, etc). Ha impartido conferencias en numerosas universidades (EHESS, CUNY-Nueva York, Oxford University, Cambridge University, Université Nice, Université de Tunis, Birkbeck College, etc). Desde 2017 es miembro del Comité Científico Internacional de la UNESCO-Slave Route.

aurelia@ugr.es 


\section{Sandra Martínez Rossi}

Profesora en la Facultad de Ciencias de la Educación, área Didáctica de la Expresión Plástica de la Universidad de Málaga.Sus líneas de investigación son antropología de la imagen, contextos etnográficos, la piel como superficie simbólica y las producciones artísticas como discursos antropológicos. Entre sus publicaciones destaca La piel como superficie simbólica. Procesos de transculturación en el arte contemporáneo (2011) y (2017). Ha realizado exposiciones nacionales e internacionales en España, Cuba y Argentina.

sandramartinez@uma.es

\section{Maria Teresa Morabito}

Es profesora agregada de Literatura española en la Universidad de Messina. Autora de numerosas publicaciones, su área de investigación es sobre todo la literatura española del Siglo de Oro. Actualmente es componente del comité científico de Illuminazioni. Rivista di Lingua Letteratura e comunicazione, y del comité técnico-científico de la "Scuola Superiore per Mediatori Linguistici" de Reggio Calabria.

mariateresa.morabito@unime.it

\section{Valentina Oldrati}

Licenciada en Historia por la Università degli Studi de Milán y doctora en Historia Moderna por la Universidad Autónoma de Madrid. Su tesis doctoral, titulada "Reos y espías. La Monarquía hispánica y los renegados (1550-1630)", se centra en la cuestión de los cristianos convertidos al Islam desde la perspectiva de los servicios de espionaje de la Monarquía hispánica.

valentina_oldrati@yahoo.it

\section{Maxim Rigaux}

Fulbright en la University of Chicago, postdoctoral visiting fellow y especializado en la literatura española del Siglo de Oro, con especial interés en la interacción entre el latín y las lenguas vernaculares de este periodo. En el año 2018 defendió su Tesis en la Universidad de Gante (Bélgica) en la que se analizaba un conjunto de poemas épicos relacionados con la batalla de Lepanto escritos en latín, castellano y catalán. Es autor de diferentes textos publicados en Hispanic Review, eHumanista y Anuario de Estudios Cervantinos.

maximrigaux@hotmail.com 


\section{María Luisa Tobar}

Catedrática de Literatura Española en la Universidad de Messina. Ha dirigido proyectos de investigación nacionales e internacionales y un master sobre teatro. Los resultados de sus investigaciones sobre teatro aurisecular, novela contemporánea, relaciones hispano-italianas y otros ámbitos han sido expuestos en congresos internacionales y en numerosas publicaciones. Es también miembro de la Real Academia Burgense de Historia y Bellas Artes.

ml.tobar1@gmail.com

\section{$M^{a}$ Dolores Villaverde Solar}

Profesora de Historia del Arte de la Universidad de A Coruña. Sus líneas de investigación se centran en la Historia del arte gallego entre los siglos XVI-XX, las relaciones patrimonio cultural- turismo y la historia de la mujer en el Arte. Ha colaborado con el periódico La Voz de Galicia en su boletín cultural A voz de Barbantia y como crítica de arte para la revista O Ollo público.

dolores.villaverde@udc.es 



\section{Revisors/es Reviewers}

L'equip editoral de la revista Millars. Espai i Història vol agraïr als/a les investigadors/res que han reatlizat les avaluacions prèvies dels articles que han estat presentats per a ser publicats en aquest volum.

Rafael Benítez (Universitat de València)

Margarita Calle (Universidad Tecnológica de Pereira, Colombia)

Raúl González Arévalo (Universidad de Granada)

Carmen de la Guardia (Universidad Autónoma de Madrid)

Francisco Javier Laviña (Universitat de Barcelona)

Ana Martínez Collado (Universidad de Castilla La Mancha)

Arturo Morgado (Universidad de Cádiz)

María Nieves Muñoz (Universidad de Granada)

Carles Rabassa (Universitat Jaume I)

Inmaculada Rodríguez (Universitat Jaume I)

Roser Salicrú (Consejo Superior de Investigaciones Científicas)

Alessandro Stella (École des Hautes Études en Sciences Sociales, Francia) 







\section{Dossier}

\section{Aurelia Martín Casares (Coord.) \\ Esclavos, criados, nobles y reyes (ss. XIV a XVII)}

\section{Presentació}

\section{Raúl González Arévalo}

La esclavitud en la España Medieval

\section{Maxim RigauX}

¿Servir con la pluma? El efecto espejo en el Austrias Carmen de Juan Latino

\section{SANDra Martínez Rossi}

Esclavos y criados: metáforas visuales y mundos imaginarios

\section{Maria Teresa Morabito y Maria luisa Tobar}

La legendaria vida del renegado calabrés Uchalí que de esclavo llega a ser rey en la historia y en la literatura

\section{Valentina Oldrati}

El triple ascenso de Pietro Velasco. Cautiverio, promoción del talento y "asimilación antagonista" entre Cristiandad e Islam (1583-1608)

\section{Tamara láÑzz Ramírez}

La población esclava según las Cédulas Reales concedidas a la familia Ponce de León en el Puerto Rico del siglo XVI

\section{Estudis}

\section{Ma Dolores Villaverde Solar}

Mujer, guerra y arte: Simbolismo en los collages de Amparo Segarra 